\begin{abstract}
UNIVERSIDADE DE BRASÍLIA
CENTRO DE DESENVOLVIMENTO SUSTENTÁVEL PÓS-GRADUAÇÃO EM DESENVOLVIMENTO SUSTENTÁVEL
\end{abstract}

Verônica Maria Bezerra Guimarães

\title{
PERTENCER À TERRA: RESISTÊNCIA DE SABERES E DIVERSIDADE DA VIDA PELOS KAIOWÁ-GUARANI
}

Brasília - DF

Fevereiro, 2016 
UNIVERSIDADE DE BRASÍLIA

CENTRO DE DESENVOLVIMENTO SUSTENTÁVEL PÓS-GRADUAÇÃO EM DESENVOLVIMENTO SUSTENTÁVEL

\title{
PERTENCER À TERRA: RESISTÊNCIA DE SABERES E DIVERSIDADE DA VIDA PELOS KAIOWÁ-GUARANI
}

\author{
Verônica Maria Bezerra Guimarães
}

Orientador: Professor Dr. Othon Henry Leonardos

Tese de Doutorado

Brasília - DF

Fevereiro, 2016 
Guimarães, Verônica Maria Bezerra.

Pertencer à terra: resistência de saberes e diversidade da vida pelos Kaiowá-Guarani. / Verônica Maria Bezerra Guimarães.

Brasília, 2016.

235 p.: il.

Tese de Doutorado. Centro de Desenvolvimento Sustentável. Universidade de Brasília, Brasília.

1. Sustentabilidade da vida. 2. Kaiowá-Guarani.

3. Pertencimento à terra. 4. Resistência. 5. Diversidade biológica e cultural. I. Universidade de Brasília. CDS.

II. Título.

É concedida à Universidade de Brasília permissão para reproduzir cópias desta tese e emprestar ou vender tais cópias, somente para propósitos acadêmicos e científicos. A autora reserva outros direitos de publicação e nenhuma parte desta tese de doutorado pode ser reproduzida sem a autorização por escrito da autora.

Verônica Maria Bezerra Guimarães 
UNIVERSIDADE DE BRASÍLIA

CENTRO DE DESENVOLVIMENTO SUSTENTÁVEL

PÓS-GRADUAÇÃO EM DESENVOLVIMENTO SUSTENTÁVEL

\title{
PERTENCER À TERRA: RESISTÊNCIA DE SABERES E DIVERSIDADE DA VIDA PELOS KAIOWÁ-GUARANI
}

\author{
Verônica Maria Bezerra Guimarães
}

Tese de Doutorado do Programa de Pós-Graduação em Desenvolvimento Sustentável do Centro de Desenvolvimento Sustentável da Universidade de Brasília apresentada à banca, como parte dos requisitos necessários para obtenção do grau de Doutora em Desenvolvimento Sustentável.

Aprovada por:

Othon Henry Leonardos, Doutor, Centro de Desenvolvimento Sustentável - UnB (Orientador)

Mônica Celeida Rabelo Nogueira, Doutora, Centro de Desenvolvimento Sustentável - UnB (Examinadora interna)

Leila Chalub Martins, Doutora, Faculdade de Educação - UnB (Examinadora interna)

Stephen Grant Baines, Doutor, Departamento de Antropologia - UnB (Examinador interna)

Cándida Graciela Chamorro Argüello, Doutora, Faculdade de História - UFGD (Examinadora externa)

Luciana Figueiredo Bomfim Lopes, Doutora, Funai (Suplente)

Brasília - DF, fevereiro, 2016 
Dedico este trabalho à memória do meu pai e às mulheres da minha família - mãe, irmãs, sobrinhas e sobrinhas-neta: Maria, Vilma, Mazé, Vera, Patrícia, Juliana, Carolina, Camila, Luana e Helena. 


\section{AGRADECIMENTOS}

Ao meu orientador Othon, por nosso encontro; pela liberdade que me foi concedida no caminho da tese, de criar e de filosofar diante do concreto; aos momentos sublimes de convivência; às preciosas lições de vida que transcenderam as orientações de "tese"; e pela generosidade de ter me acolhido como orientanda. Agradeço por ter tido a oportunidade de conhecer o homem amoroso pela vida, pelos índios, pela gente, pelo mundo. Obrigada por ter me aberto portas de percepções da sustentabilidade da vida e por ter acreditado na dimensão "bonita" que tenho em mim. Por ter me mostrado que o trabalho científico também é emoção e poesia, onde deve dialogar o olhar crítico e o sentimento, sem ser piegas, pondo a alma no trabalho. Nesta tentativa, muitos caminhos foram percorridos para se chegar "ao tema", em um processo de construção e de desconstrução em que muitas coisas bonitas me foram reveladas. A Simone, por nos alimentar (a mim e a Othon) de corpo e alma com sua comida recheada de ternura nos momentos de encontro que tive em sua casa.

Ao meu coorientador no Instituto de Investigaciones Sociales da UNAM, Professor Enrique Leff, pela acolhida e liberdade em me receber.

Às pessoas com quem fiz o trabalho de campo, por sua convivência e generosidade.

À mamãe e à tia Reginalda, minhas xamãs.

Às minhas irmãs Mazé, Vera e Vilma pelo amor e apoio de toda vida.

A Mazé, pela cumplicidade, pelos conselhos e cuidado. Obrigadíssima pela revisão da tese.

A Portugal, pelas risadas e por fazer minha irmã feliz.

A Patrícia e Luana, por nossa aproximação e apoio em Brasília.

À família Lima: Sarah, pela força em Brasília, e Marcos, por tudo que foi.

À família Ramirez e Juliana Merçon, pela acolhida no México.

Aos professores do CDS, CEPPAC e CEAM da Unb.

Aos colegas-amigos de turma, em especial às meninas Andreia, Catherine, Chiara e Maria Amélia; e aos meninos, Luís e Marcos.

Aos amigos espalhados pelo mundo: Sarah, Marília, Suzana, Adélia, Masri, Victor, Raíza, Sandra, César, Roberta Patrícia, Rose, Wagner, Margarete e Zé Gomes.

A Wanise, pelo carinho de amiga-irmã.

A Marinês, pelo cuidado com a minha casa e minhas filhotas nos muitos momentos de ausência.

A Nina e Mel, por existirem em minha vida.

A Vito, Levi, Graciela, Eliel, Joelson e Vander, pelo apoio e orientações.

Às instituições: UFGD, UnB (CDS, CEPPAC, CEAM), IIS/UNAM, CAPES. 
Já não preciso de rir. Os dedos longos do medo largaram minha fronte.

$E$ as vagas do sofrimento me arrastaram para o centro do remoinho da grande força, que agora flui, feroz, dentro e fora de mim...

Já não tenho medo de escalar os cimos onde $o$ ar limpo e fino pesa para fora, e nem deixar escorrer a força dos meus músculos, e deitar-me na lama, o pensamento opiado...

Deixo que o inevitável dance, ao meu redor, a dança das espadas de todos os momentos.

E deveria rir, se me retasse o riso, das tormentas que poupam as furnas da minha alma, dos desastres que erraram o alvo do meu corpo...

(João Guimarães Rosa, Consciência Cósmica)

Las sensaciones son percepciones embrionárias, pues, ?sentiríamos si no nos diésemos cuenta de que sentimos? A su vez, la percepción es concepción; al percibir la realidade le imponemos imediatamente uma forma a nuestra percepción, la construimos: "cada percepción es um acto de creación". 


\section{RESUMO}

A destruição das matas e a degradação ambiental dos territórios de ocupação tradicional Kaiowá-Guarani no sul de Mato Grosso do Sul, em diversas fases de processos de colonização, a partir do início do século $X X$, vêm provocando significativos impactos na organização social e, consequentemente, no seu modo de ser. $O$ modelo do entorno impõe o seu legado e os seus passivos por ocasião da regularização das terras indígenas de antigas fazendas de gado e de plantação de monoculturas. Este trabalho se propõe a construir interdisciplinaridade na sustentabilidade, com uma base em ciências sociais. A presente tese estuda as interfaces natureza/cultura baseadas nas categorias de pertencimento ao local e diversidade biológica e cultural como instrumento de resistência de saberes para a compreensão da ideia de sustentabilidade pelos kaiowá-guarani do sul de MS através de três estudos de caso em terras indígenas com situações fundiárias diferentes. A partir de estudos das terras de Te'ýkue, Sucuruíy e Jatayvary foi possível descrever percepções e memórias do passado em suas ressignificações presentes sobre a importância da terra para a continuidade de um modo de ser que existe na diversidade da vida e de saberes. Da destruição ambiental para as possibilidades de restauração, revitalização e repovoamento da terra com diversidade, os kaiowá-guarani têm muito a ensinar na construção de uma sustentabilidade, com dimensão espiritual, baseada na profunda noção de pertencer. $O$ sentimento de pertencimento é um forte elemento de resistência à terra, na terra e pela terra.

Palavras-chave: Sustentabilidade da vida; Kaiowá-Guarani; Pertencimento à terra; Resistência; Diversidade biológica e cultural. 


\begin{abstract}
The destruction of forests and environmental degradation of traditional occupation of territories Kaiowá-Guarani in the south of Mato Grosso do Sul, in various stages of colonization processes, from the early twentieth century, has led to significant impacts on the social organization and consequently in his way of being. The surroundings of the model imposes its legacy and its liabilities at the time of settlement of indigenous lands of ancient cattle farms and monoculture plantation. This study aims to build interdisciplinary sustainability, with a base in social sciences. This thesis studies the interfaces nature/culture based on membership categories of the local and biological and cultural diversity as knowledge of an instrument of resistance to understanding the idea of sustainability by MS southern Kaiowá-Guarani based on three case studies on land indigenous land with different situations. From studies of land Te'ýkue, Sucurui'y and Jatayvary was possible to describe perceptions and memories of the past in their new meanings present on the importance of land for the continuity of a way of being that exists in the diversity of life and knowledge. Environmental destruction to restoration possibilities, revitalization and repopulation of the land with diversity, the Kaiowá-Guarani have much to teach in building a sustainable, with spiritual dimension, based on the deep sense of belonging. The feeling of belonging is a strong element of earth resistance, in the earth and by the earth.
\end{abstract}

Keywords: Sustainability of life; Kaiowa-Guarani; Belonging to the land; Resistance; Biological and cultural diversity. 


\section{RESUMEN}

La destrucción de los bosques y la degradación ambiental de la ocupación tradicional de los territorios kaiowá-guaraní en el sur de Mato Grosso do Sul, en distintas etapas de los procesos de colonización, de principios del siglo $\mathrm{XX}$, ha dado lugar a impactos significativos en la organización social y en consecuencia en su forma de ser. Los alrededores del modelo impone su legado y sus pasivos al momento de la liquidación de las tierras indígenas de las antiguas fincas ganaderas y plantaciones de monocultivo. Este estudio tiene como objetivo construir la sostenibilidad interdisciplinaria, con una base en ciencias sociales. Esta tesis estudia la interfaces de naturaleza/cultura basada en categorías de miembros de la diversidad local y biológica y cultural como el conocimiento de un instrumento de resistencia a la comprensión de la idea de la sostenibilidad por MS sur kaiowá-guaraní basado en tres estudios de caso sobre la tierra tierras indígenas con diferentes situaciones. A partir de estudios de Te'ýkue tierra, Sucurui'ye y Jatayvary era posible describir las percepciones y recuerdos del pasado en sus nuevos significados presentes en la importancia de la tierra para la continuidad de una forma de ser que existe en la diversidad de la vida y el conocimiento. La destrucción ambiental a las posibilidades de restauración, revitalización y repoblación de la tierra con la diversidad, la kaiowá-guaraní tiene mucho que enseñar en la construcción de una economía sostenible, con la dimensión espiritual, basado en el profundo sentido de pertenencia. El sentimiento de pertenencia es un fuerte elemento de resistencia de tierra, en la tierra y por la tierra.

Palabras clave: Sostenibilidad de la vida; Kaiowá-guaraní; pertenencia a la tierra; resistencia; Diversidad biológica y cultural. 


\section{LISTA DE ILUSTRAÇÕES}

Fotografia 1 - Faixa pela demarcação no Aty Guasu em Yvy Katu, 2014 .............................. 38

Fotografia 2 - Muda de árvore no meio do colonião em Mbopiy, Téýikue .............................. 60

Fotografia 3 - Plantação de cana-de-açúcar, braquiária e formigueiro em Jatayvary .............. 62

Fotografia 4 - Centro da Reserva Indígena Te ýikue ............................................................. 107

Fotografia 5 - Mata replantada atrás da Escola Ñandejara ................................................. 113

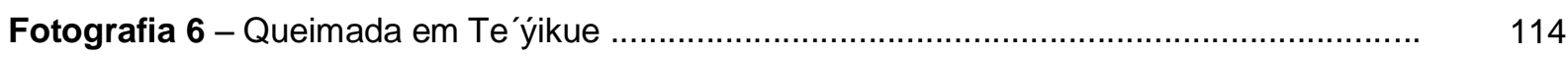

Fotografia 7 - Escola de Ensino Médio - Flor da Terra ................................................... 117

Fotografia 8 - Viveiro de mudas ............................................................................... 124

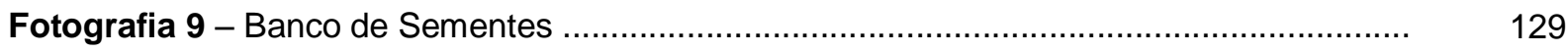

Fotografia 10- Horta na Unidade ........................................................................... 130

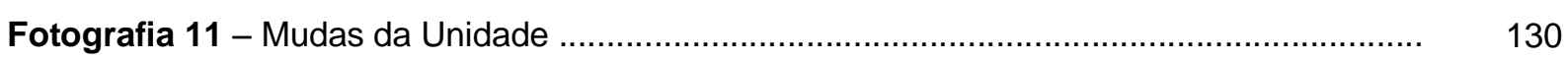

Fotografia 12 - Córrego na Unidade Experimental ............................................................ 131

Fotografia 13 - Represa na Unidade ............................................................................ 133

Fotografia 14 - Plantação de urucum no meio da braquiária ............................................... 133

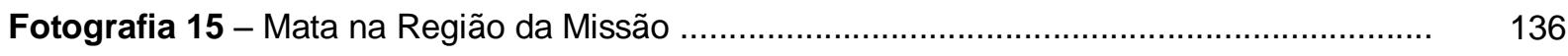

Fotografia 16 - Limite da Missão com fazenda ........................................................... 136

Fotografia 17 - Cocho de Cedro em Mbokaja ……............................................................. 138

Fotografia 18 - Colonião em Mbopiy ...................................................................... 141

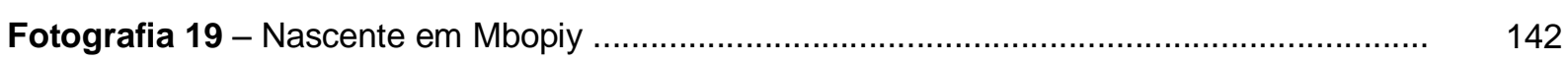

Fotografia 20 - Córrego em Mbopiy ……...................................................................... 143

Fotografia 21 - Casa de sapé em Sucuruíy ……….................................................... 151

Fotografia 22 - Monocultura no entorno de Sucurui'y ..................................................... 151

Fotografia 23 - Centrinho de Sucurui'y …………..................................................... 152

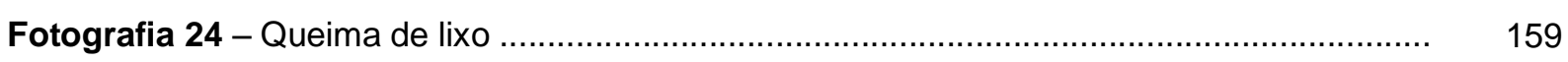

Fotografia 25 - Cartaz do 5o Aty Guasu Kunhãngue Arandu Ka'aguy ................................... 161

Fotografia 26 - Formigueiro pedra ......................................................................... 163

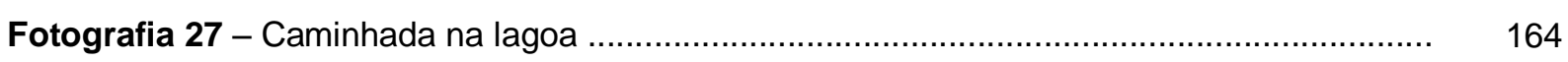

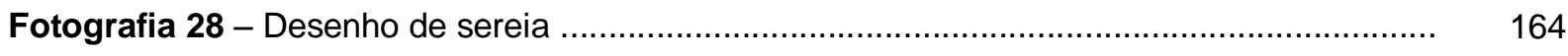

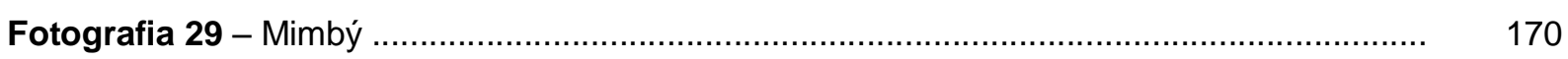

Fotografia 30 - Rio Sucuri ou Córrego Cachoeira …....................................................... 172

Fotografia 31 - Retirada da casca do chiru ................................................................. 173

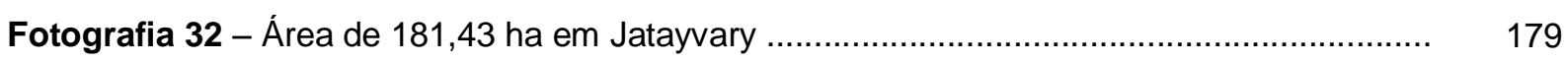

Fotografia 33 - Entrada de Jatayvary ......................................................................... 180

Fotografia 34 - Estrada de terra que corta a terra indígena ............................................. 180

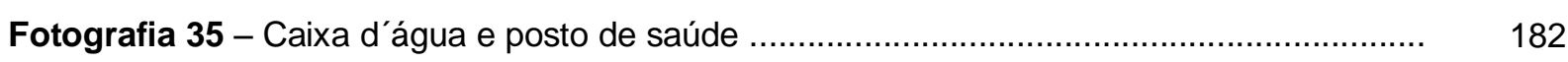

Fotografia 36 - Informação sobre o sistema de abastecimento de água ................................ 183

Fotografia 37 - Embalagem de agrotóxico para armazenamento de água ............................. 183

Fotografia 38 - Córrego Jatayvary …….................................................................... 184 
Fotografia 39 - Primeira sala de aula na escola Graça de Deus ........................................... 187

Fotografia 40 - Ávore derrubada na mata ..................................................................... 191

Fotografia 41 - Limite entre a plantação de cana-de-açúcar e a casa da família ..................... 193

Fotografia 42 - Usina Monteverde/Bunge ......................................................................... 197

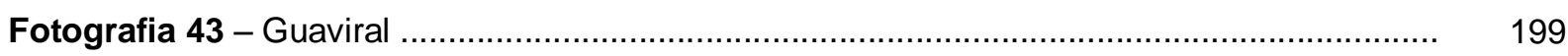

Fotografia 44 - Braquiária, plantas nativas e mata ............................................................. 200

Mapa 1 - Terras indígenas Kaiowá-Guarani ........................................................................ 42

Mapa 2 - Representação da Reserva Indígena Te'ýikue na época da criação ......................... 105

Mapa 3 - Regiões atuais da Reserva Indígena Te'ýikue ...................................................... 106

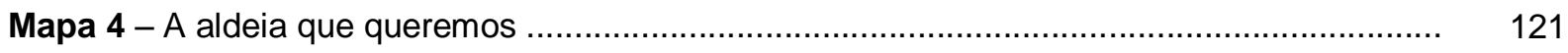

Mapa 5 - Cartograma do uso da terra de Jatayvary (georreferenciado) ….............................. 195

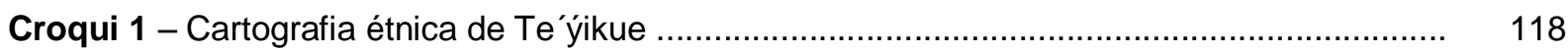

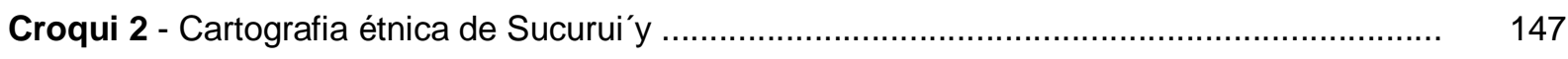

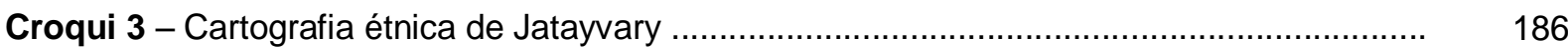




\section{LISTA DE ABREVIATURAS E SIGLAS}

AGU - Advocacia Geral da União

APP - Área de Preservação Permanente

Art. - Artigo

BID - Banco Interamericano de Desenvolvimento

BIRD - Banco Internacional para Reconstrução e Desenvolvimento

BNDES - Banco Nacional de Desenvolvimento Econômico e Social

BR - Rodovia Federal

CAND - Colônia Agrícola Nacional de Dourados

CAPES - Coordenação de Aperfeiçoamento de Pessoal de Nível Superior

CDS - Centro de Desenvolvimento Sustentável

CF - Constituição Federal de 1988

CIMI - Conselho Indigenista Missionário

CMMAD - Comissão Mundial sobre Meio Ambiente e Desenvolvimento

CNUMAD - Conferência das Nações Unidas para o Meio Ambiente e Desenvolvimento $\mathrm{CO}^{2}$ - Dióxido de Carbono

CRAS - Centro de Referência da Assistência Social

CTL - Coordenação Técnica Local da FUNAI

DNER - Departamento Nacional de Estradas de Rodagem

DNIT - Departamento Nacional de Infraestrutura de Transportes

DOU - Diário Oficial da União

EJA - Escola de Jovens Adultos

ECO-92 - Conferência das Nações Unidas sobre Meio Ambiente e Desenvolvimento

FAIND - Faculdade Intercultural Indígena

FNDE - Fundo Nacional de Desenvolvimento da Educação

FUNAI - Fundação Nacional do Índio

GEF - Fundo Global para o Meio Ambiente

GT's - Grupos Técnicos

ha - Hectare

IBAMA - Instituto Brasileiro de Meio Ambiente e dos Recursos Naturais Renováveis

IBGE - Instituto Brasileiro de Geografia e Estatística

IMASUL - Instituto de Meio Ambiente de Mato Grosso do Sul

IIS - Instituto de Investigaciones Sociales

km - Quilômetro

MPF - Ministério Público Federal

MS - Mato Grosso do Sul

MX - México

NEPPI - Núcleo de Estudos e Pesquisas das Populações Indígenas

No. - Número 
OIT - Organização Internacional do Trabalho

ONG's - Organizações não governamentais

ONU - Organização das Nações Unidas

PDA - Subprograma Projetos Demonstrativos

PEC - Proposta de Emenda à Constituição

P/K - Pai-Tavyterã/Kaiowá

PKN - Projeto Kaiowá Ñandeva

PL - Proposta de Lei

PNAP - Plano Nacional de Áreas Protegidas

PNB - Produto Nacional Bruto

PNGATI - Política Nacional de Gestão Ambiental e Territorial em Terras Indígenas

PNUMA - Programa das Nações Unidas para o Meio Ambiente

PPG7 - Programa Piloto para a Proteção das Florestas Tropicais do Brasil

PPTAL - Projeto Integrado de Proteção às Populações e Terras Indígenas da Amazônia Legal

PRONAF - Programa Nacional de Fortalecimento da Agricultura Familiar

$\mathbf{R} \$$ - Real

SAFE - Sistema Agroflorestal

SESAI - Secretaria Especial da Saúde Indígena

SISNAMA - Sistema Nacional do Meio Ambiente

SPI - Serviço de Proteção aos Índios

SPILTN - Serviço de Proteção aos Índios e Localização de Trabalhadores Nacionais

SPU - Secretaria do Patrimônio da União

TAC - Termo de Compromisso de Ajustamento de Conduta

$\mathrm{TI}$ - Terra Indígena

UCDB - Universidade Católica Dom Bosco

UEMS - Universidade Estadual de Mato Grosso do Sul

UFGD - Universidade Federal da Grande Dourados

UFMS - Universidade Federal de Mato Grosso do Sul

UNAM - Universidad Nacional Autónoma de México

UnB - Universidade de Brasília

UNESCO - Organização das Nações Unidas para a Educação, a Ciência e a Cultura 


\section{SUMÁRIO}

\section{LISTA DE ILUSTRAÇÕES}

\section{LISTA DE ABREVIATURAS E SIGLAS}

INTRODUÇÃO

1 POVOS DA MATA NA TERRA SEM MATO

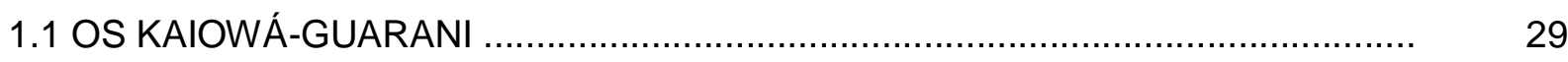

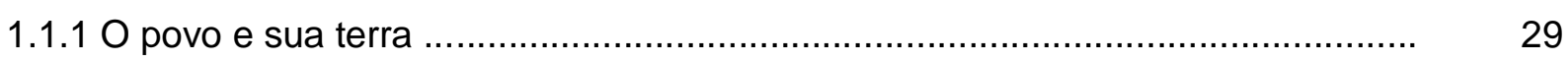

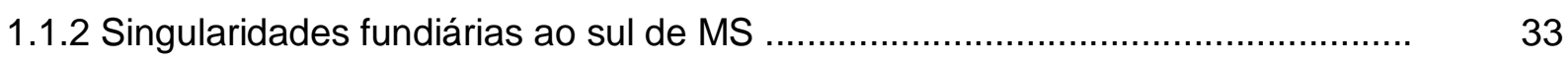

1.2 COLONIALIDADES E TRANSFORMAÇÕES AMBIENTAIS ............................. 43

1.2.1 O labirinto de colonialidades .................................................................. 43

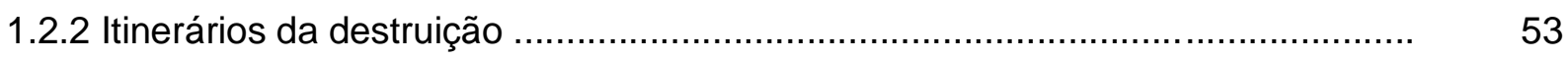

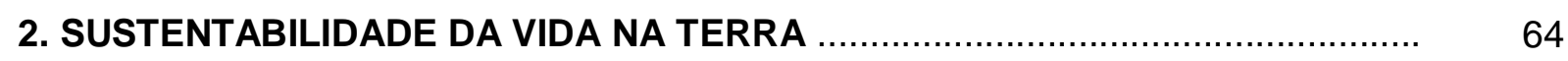

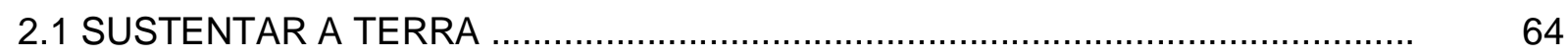

2.1.1 Sustentabilidade substantiva, sustentabilidades adjetivas ................................. 64

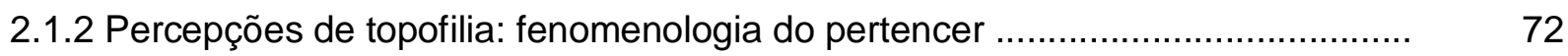

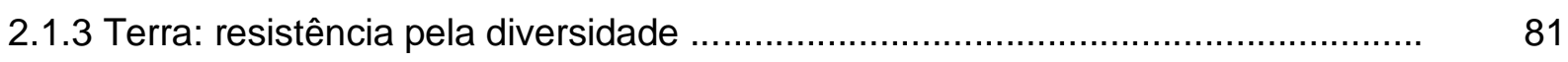

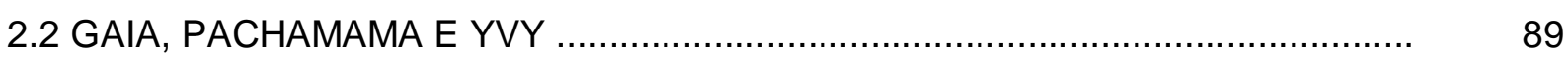

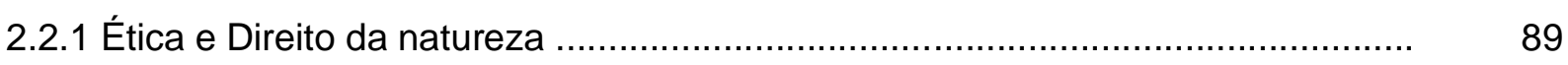

2.2.2 Interfaces indígenas: natureza e sociedade ............................................... 96

2.2.3 Os jara como donos dos seres na terra .................................................. 99

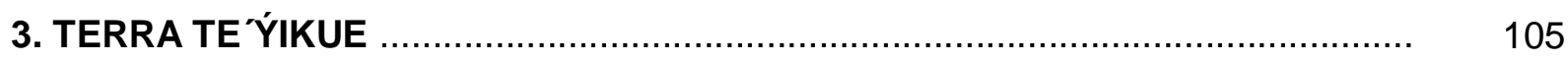

3.1 A ALDEIA ANTIGA E SEU POVO …....................................................... 105

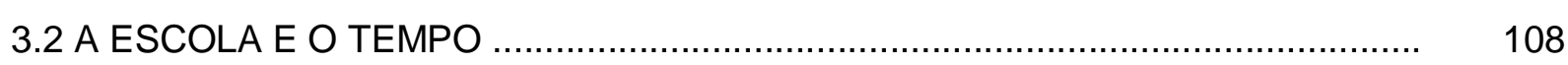

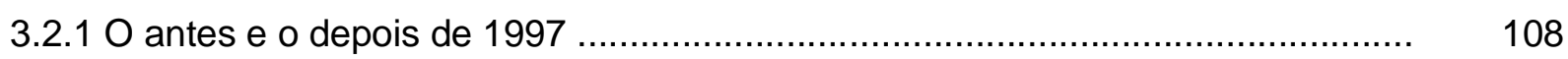

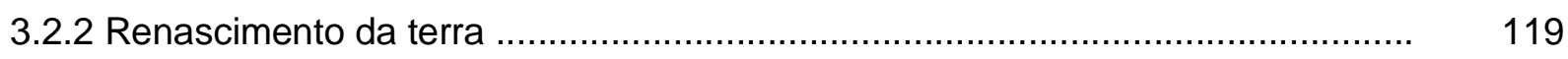

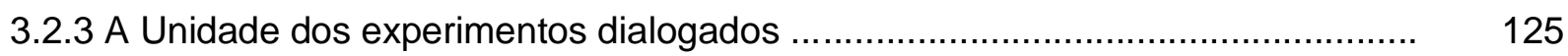

3.3 GUARDIÕES DA NATUREZA E MESTRES TRADICIONAIS ........................... 135

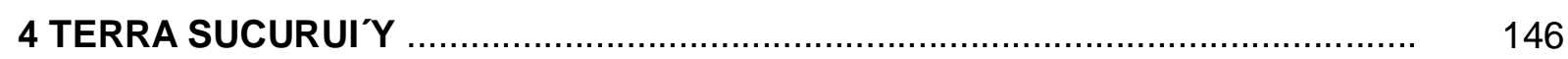

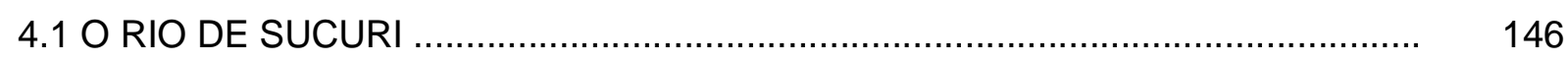

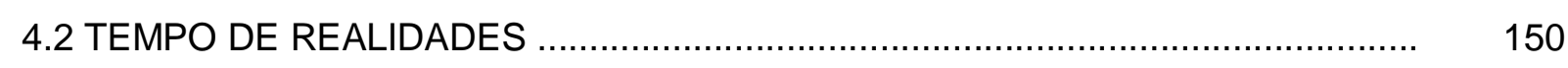

4.2.1 A terra: tem sucuri, tem onça, mas também braquiária ..................................... 150

4.2.2 A escola: onde as sereias povoam a imaginação .......................................... 156

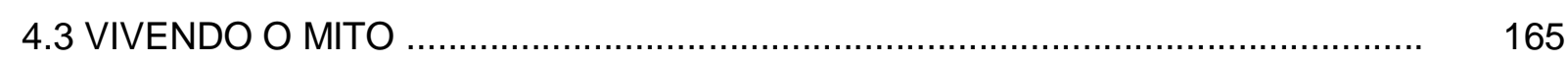

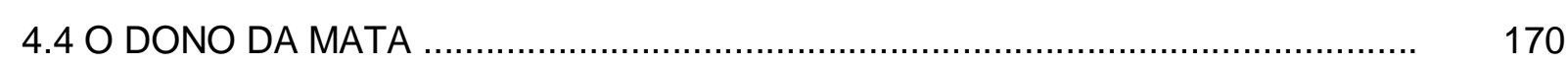




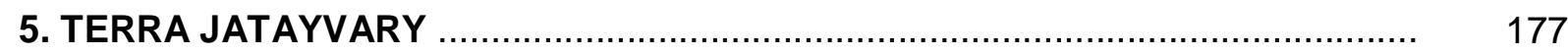

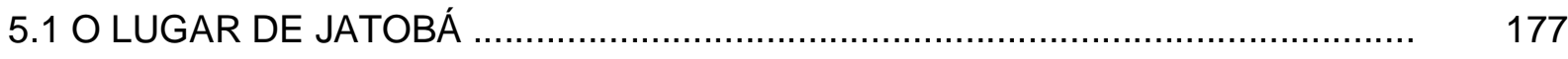

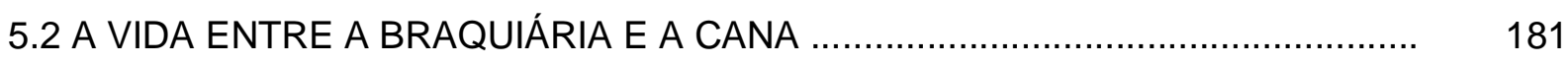

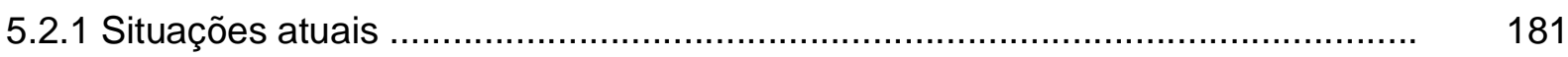

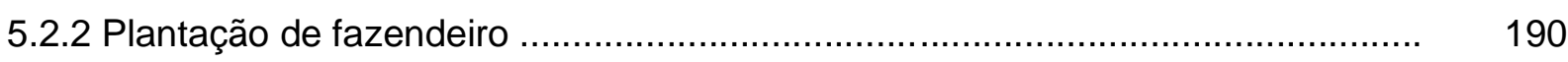

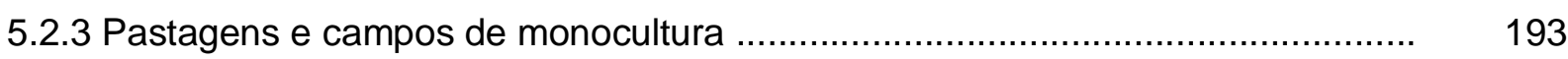

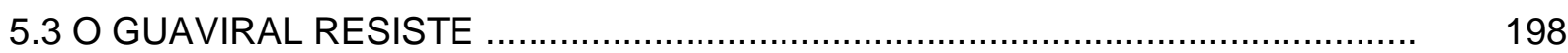

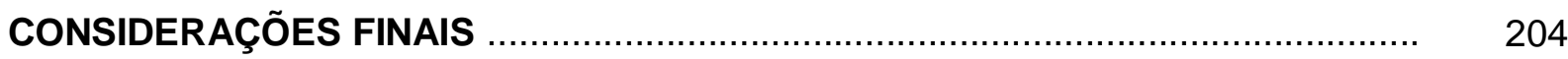

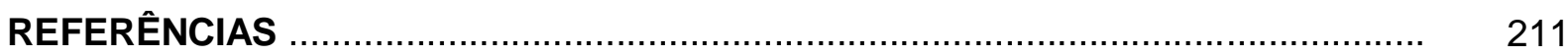

ANEXOS

GLOSSÁRIO 


\title{
INTRODUÇÃO
}

\author{
PANORAMA
}

A presente tese está situada nos estudos de interdisciplinaridade na sustentabilidade, com uma base em ciências sociais ${ }^{1}$. A opção por um Doutorado em Desenvolvimento Sustentável no CDS/UnB propiciou a oportunidade de refletir sobre modelos de sustentabilidade a partir de concepções de um povo, que independentemente do rótulo de sustentável, adota um modelo de vida, em que os séculos de colonização não foram capazes de subjugá-lo totalmente. Modelo este que, junto com o de outros povos tradicionais, inspira e alimenta concepções das mais belas teorias ecológicas. Aliás, para eles, terra e meio ambiente faz parte de um todo, sem dicotomias, frações ou subdivisões pseudo-didáticas. Terra, natureza e saberes para uma vida em harmonia, respeito e cuidado entre os seres constitui a essência do seu modo de ser.

Venho de experiências do Direito Ambiental, onde no mestrado trabalhei com questões relacionadas à sustentabilidade urbana. Mas, uma mudança para o MS me fez conhecer realidades até então longínquas. Um ambiente propício para debates sobre questões indígenas e fundiárias na UFGD me aproximou de temas sobre direito indígena; justiça e racismo ambiental; estudos de impacto e licenciamento ambiental do setor sucroalcooleiro em terras indígenas. O processo de construção deste doutorado me propiciou rever a minha (de)formação em Direito. Foram muitas as idas e vindas a partir do meu porto seguro. Naturalmente surgiram medos, dificuldades, negativas e inseguranças ao lidar com saberes que não "domino", mas ao mesmo tempo encantamento com o novo. Muito mais que aprender saberes interdisciplinares, esta experiência me revelou ambientes, relações e posturas interdisciplinares.

O que sabia sobre sustentabilidade ${ }^{2}$ foi sendo paulatinamente desconstruído. A sustentabilidade passou a ser o tudo e o nada. Fui me afastando cada vez mais de visões

\footnotetext{
${ }^{1}$ Moran (2011, p. 50) apresenta um panorama atualizado do estado das pesquisas que envolvem as interações homem-meio ambiente, numa perspectiva transdisciplinar, que também tem sido chamada de ciência social ambiental, ciência da sustentabilidade ou pesquisas dos sistemas naturais humanos acoplados. Ele propõe uma abordagem colaborativa que dialogue com ferramentas e linguagens utilizadas pelas ciências sociais e naturais visando transpor os seus limites disciplinares ao lidarem com o viés ambiental e sua complexidade rumo a uma ciência integrativa.

${ }_{2}^{2}$ As diferentes ideias de ambientalismo e de sustentabilidade revelam relações de poder bastante desiguais entre os formuladores de políticas públicas globais e nacionais e as realidades locais do mundo da vida. O conceito de desenvolvimento sustentável, com base no Relatório Nosso Futuro Comum, conhecido como Relatório Brundtland, foi construído a partir de um consenso global de crise ambiental. Neste sentido, políticas internacionais passaram a influenciar modelos de políticas e normativas nacionais baseadas em estratégias de modernização ecológica através de tecnologias e mercados que passaram a adotar discursos e posturas ditas sustentáveis. O Estado passou a administrar a questão ambiental através de uma burocracia que legitima comportamentos econômicos de risco como atividades e empreendimentos "potencialmente poluidores e degradadores do meio ambiente". Neste contexto, o modelo econômico hegemônico transforma o "meio ambiente" em "bens ambientais" passíveis de privatização, mercantilização e consumo.
} 
normativas, burocráticas e modernizantes sobre o que é ser sustentável. A partir daí, o curto, mas intenso trabalho de campo foi me revelando sentimentos que já estavam em ebulição. Isto me fez aproximar de dimensões também subjugadas nos debates internacionais e nacionais preponderantes sobre sustentabilidade, ou seja, um viés perceptivo, sentimental, místico, espiritual que compõem questões essenciais para grupos humanos que vivem a terra porque possuem fortes vínculos de pertencimento a ela. Hoje em dia, sigo sem saber o que sei sobre esta palavra em que cabem as mais diversas ideologias, mas cada vez mais me aproximo do que sinto sobre sustentabilidade.

O caminho que percorri até chegar a este texto passou por muitas tangentes, desde as discussões sobre pagamentos por serviços ambientais através do mecanismo de redução e emissões por degradação e desmatamento (REDD+) em terras indígenas até a política nacional de gestão ambiental e territorial de terras indígenas (PNGATI). No entanto, o trabalho de campo me revelou outras rotas e, a partir dele, muito foi redefinido. A relação de pertencimento à terra do kaiowá atual, em suas diversas versões, diante de situações fundiárias semelhantes, mas ao mesmo tempo específicas, me foi revelando um mosaico de percepções.

Os guarani-kaiowá são um povo vastamente etnografado. Mas como uma nova tese busca apontar e/ou suprir lacunas, através de uma contribuição aos debates que se seguem, situo este trabalho como uma tese em desenvolvimento sustentável que procura discutir as várias faces da sustentabilidade para os kaiowá do sul de MS.

O objeto de estudo da tese consiste nas interfaces natureza/cultura dos kaiowáguarani do sul de MS numa perpectiva de sustentabilidade de vida na terra, tomando como base a ideia de pertencimento ao local e diversidade biológica e cultural enquanto instrumento de resistência de seres e saberes.

Tem-se como objetivo geral analisar o pertencimento à terra pelos kaiowá-guarani como elemento de resistência pela diversidade da vida na sustentabilidade. Os objetivos específicos são: a) caracterizar o pertencimento à terra como um dado importante para a composição da ideia de sustentabilidade; b) identificar os diversos tipos de resistência face aos processos de destruição da diversidade; c) descrever as formas kaiowá-guarani de proteção da terra.

Busquei, a partir de três estudos de caso em terras indígenas com situações fundiárias diferentes, descrever memórias do passado em suas ressignificações presentes sobre a importância da terra (em sua mais ampla concepção, integrando todos os elementos da natureza, inclusive o ser humano) para a continuidade de um modo de ser que existe na diversidade da vida (incluindo a própria terra) e de saberes. Modo este, oprimido ao longo de diversos processos de colonização que se perpetuam até hoje, subjugado por uma racionalidade monocultural que impôs o seu modelo sobre a terra e sobre povos do mato. 
Procurei estabelecer pontes com a vasta etnohistória dos Guarani-Kaiowá em MS. Mas este, não é um trabalho etnográfico, não é uma tese de antropologia. Utilizei técnicas da etnografia a partir das leituras que realizei, principalmente, a partir das muitas etnografias feitas sobre os guarani-kaiowá para minimamente aprender o ofício. Observam-se no texto possibilidades de diálogo entre discussões filosóficas, históricas, geográficas, sociológicas, políticas, antropológicas e jurídicas sobre teorias da natureza e da sustentabilidade, com um viés do pensamento latino-americano crítico sobre os processos de colonização.

É uma tese construída com base numa interdisciplinaridade de saberes científicos e da sabedoria dos interlocutores ${ }^{3}$ que compõem as diversas falas ao longo do texto. Respeitando e dando voz a sua palavra, na perspectiva de aprender com o outro. A força da palavra que molda o modo de ser, de conviver com a Terra, em suas defesas da diversidade biológica e cultural. Neste trabalho, o povo e as terras kaiowá-guarani são sujeitos da pesquisa. Como existem muitas visões da interdisciplinaridade ${ }^{4}$, tentei realizar trocas e diálogos com saberes não acadêmicos, o que justificaria a escolha das terras investigadas e das pessoas que compõem os diálogos.

Algumas influências me auxiliaram nesta caminhada, como Arturo Escobar, Enrique Leff, Philippe Descola, Vandana Shiva e Leonardo Boff, cujos aportes teóricos me fizeram ir a campo e a partir dele voltar para a reflexão teórica. Autores, com quem, de diversas formas estabeleci conexões presenciais e de análises sobre suas obras. A convergência do pensamento sobre ciência e saberes; racionalidade ambiental e epistemologia ambiental; monocultura da mente, entre outros, lançaram luzes sobre pontos de discussão.

Genericamente, fala-se da importância dos povos e das terras indígenas para a conservação ambiental. É o modo de ser que se retroalimenta das profundas relações estabelecidas com a terra. Seus modelos seriam menos impactantes e mais harmônicos. A ideia de complementariedade com a terra revela interessantes contribuições para se pensar modelos teóricos e de gestão de espaços naturais. Está presente na tese uma visão de natureza pelos kaiowá, levando-se em consideração de que esta não é algo genérico. São

\footnotetext{
${ }^{3}$ A partir de um discurso sobre as ciências, Santos desenvolveu uma perspectiva epistemológica baseada na diversidade cultural de ser e estar no mundo que nomeou de ecologia dos saberes, cujo desafio é romper, na teoria e na prática, a monocultura do saber. Na sua concepção, a ecologia dos saberes: "É um conjunto de epistemologias que partem da possibilidade da diversidade e da globalização contra-hegemônicas e pretendem contribuir para as credibilizar e fortalecer. Assentam em dois pressupostos: 1) não há epistemologias neutras e as que clamam sê-lo são as menos neutras; 2) a reflexão epistemológica deve incidir não nos conhecimentos em abstrato, mas nas práticas de conhecimento e seus impactos noutras práticas sociais". (SANTOS, 2010b, p. 154).

${ }^{4}$ Para Leff (2010, p. 16-7) a interdisciplinariedade teórica ambiental caminha para um diálogo de saberes, este: "abre uma via de compreensão da realidade a partir de diferentes racionalidades; estabelece um diálogo intercultural a partir das identidades coletivas e dos sentidos subjetivos, para além da integração sistêmica de objetos fragmentados do conhecimento. A complexidade ambiental não remete a um todo - nem a uma teoria de sistemas, nem a um pensamento holístico, nem a uma conjunção de olhares multirreferenciais. É, ao contrário, a ruptura da relação do conhecimento com o real para uma nova relação entre o real e o simbólico".
} 
visões também de pessoas, que embora paire fortemente sobre elas suas condições étnicas e de família, não deixam de ser fruto das suas experiências como sujeito.

Defendo a ideia de que conservação da terra ou modelos de gestão ambiental tem melhores chances de serem bem sucedidos se houver o sentimento de pertencimento envolvido, como nos mostra os kaiowá. O pertencimento perpassa todo o processo de luta por suas terras de ocupação tradicional, motivando sua política para reavê-las de "proprietários", cujos títulos foram legitimados pelo estado. Pertencimento que está relacionado com suas memórias individuais e coletivas; com as atribuições dos nomes dos lugares a que se referem; com a alimentação; com as plantas e animais sagrados; com sua agricultura; com seus rituais e com a reverência a natureza.

Os processos de destruição da terra ou da natureza devido aos ciclos de "desenvolvimento" regional não foram capazes de apagar os saberes sobre a terra e esta, juntamente, com os povos resistem na sua diversidade, muitas vezes "ilhados" face às paisagens e mentalidades monoculturais.

O modelo do entorno impõe o seu legado e os seus passivos por ocasião da regularização das terras indígenas de antigas fazendas de gado e de plantação de monoculturas. Os arredores lançam sobre as terras indígenas sementes de braquiária; pulverizações de agrotóxico; contaminação de corpos d'água por defensivos agrícolas e impede a comunicação das espécies, reduzindo a sua reprodução e diversidade. A ausência de áreas mistas entre terras indígenas e fazendas, como zonas de amortecimentos ou áreas-tampão ampliam o rastro de destruição corroendo as bordas dos limites demarcados como indígenas.

As fazendas também estão dentro das terras indígenas, seja pelas estradas que as cortam levando sua produção e provocando toda espécie de incômodos e riscos, ou pela influência de que plantar uma espécie, seja milho, soja ou cana-de-açúcar, seria a melhor opção como projeto de desenvolvimento através do arrendamento de suas terras de uso exclusivo.

Mas a diversidade natural resiste de diversas formas: através da plantinha medicinal que está escondida sobre o colonião com mais de um metro em Te'ýkue e embaixo da braquiária em Sucuruíy; através do guaviral em Jatayvary e da onça que passeia na mata de Sucuruíy. A diversidade de saberes também resiste através dos diálogos entre rezadores e escola; das demandas pela construção de casas de reza; pela continuidade de rituais; pelo conhecimento das plantas e procedimentos de cura e pelos modelos de recuperação ambiental. A revitalização das terras arrasadas pelos processos de colonização passa pela cultura, mas também pelas estratégias dialogadas com conhecimentos nãoindígenas, como é o caso do projeto de recuperação ambiental de Te ýkue. 
A contribuição do modelo kaiowá-guarani de proteção da terra traz consigo a dimensão do sagrado, da reverência, do respeito aos ciclos de vida e de recuperação da natureza, do pertencimento e da ligação com a terra e com os seres que a habitam. Os seres e os saberes numa ideia de complementariedade. Da terra que produz o alimento e o modo de ser. Modo de ser baseado na oralidade, nas histórias que são perpassadas pelas gerações, pela fala mansa, doce e metafórica. $O$ doce sabor da fala guarani. O que seria esta doçura? A não-violência, o modo de ser, de viver, de se relacionar, de pertencer à terra.

Os kaiowá, ka'aguygua ou ka'aygua, literalmente, os da mata ou povo da mata são tradicionalmente povos agricultores, possuidores de uma forte identidade territorial. A cosmologia e o conhecimento guarani-kaiowá possuem uma dimensão do sagrado sobre a terra e os seres que a habitam. Os mitos são vivenciados na realidade de acordo com seu modo de ser.

Mesmo diante de séculos de colonização com seus ciclos econômicos destrutivos, as terras indígenas Guarani-Kaiowá guardam respostas inspiradoras para a ideia de sustentabilidade. E revelam uma riqueza de sociobiodiversidade que não há no entorno. Seu modo de ser pode contribuir para a teoria ecológica, para a sociobiodiversidade, de modo a promover transformações na sociedade, na economia e no meio ambiente envolvente.

A sociedade atual é desenraizada, sem topofilia. Diferentemente dos kaiowá-guarani em que terra e vida compõem uma comunidade de origem terrestre, de natureza humana e de destino planetário. Há uma simplicidade na complexidade, onde esta constitui uma religação com os sistemas integrados do universo. O sistema vida guarani-kaiowá, com sua dimensão espiritual, poética e telúrica da sustentabilidade da terra, representam o que poderia ter sido e o que ainda pode ser: a sabedoria para uma vida melhor.

A resiliência deste povo e da terra mostra a força e a esperança contra a racionalidade de um sistema econômico que condena a terra e as pessoas. O que resistir? A nós mesmos e aos ciclos de destruição. As resistências confluem para a justiça e dignidade do homem e da terra, compondo ecos de um povo que ama a terra por uma sustentabilidade da vida com doçura, amor e esperança ${ }^{5}$.

\footnotetext{
${ }^{5}$ Adoto a noção de esperança crítica de Paulo Freire (1992, p.11), que a situa como uma necessidade ontológica. "Enquanto necessidade ontológica a esperança precisa da prática para tornar-se concretude histórica. É por isso que não há esperança na pura espera, nem tampouco se alcança o que se espera na espera pura, que vira, assim, espera vã. Sem um mínimo de esperança não podemos sequer começar o embate mas, sem o embate, a esperança, como necessidade ontológica, se desarvora, se desendereça e se torna desesperança que, às vezes, se alonga em trágico desespero. Daí a precisão de uma certa educação da esperança. É que ela tem uma tal importância em nossa existência, individual e social, que não devemos experimentá-la de forma errada, deixando que ela resvale para a desesperança e o desespero. Desesperança e desespero, consequência e razão de ser da inação ou do imobilismo".
} 


\section{PERCURSOS METODOLÓGICOS}

Existem reflexões que possuem pontos comuns para a maioria das sociedades indígenas. Mas, procurei evitar generalizações que envolvam estudos entre povos indígenas e proteção ambiental ou sustentabilidade. Por isso, mesmo sabendo das questões comuns que envolvem sociedades indígenas na América Latina, no Brasil, no MS, para os Kaiowá procurei visualizar pontos de vistas e percepções dos sujeitos envolvidos nas conversas. Pois, mesmo numa única terra indígena existem muitas percepções sobre as questões investigadas e até mesmo contradições.

A escolha das terras se deu a partir da construção do tema e do projeto de pesquisa, em que esteve presente a ideia de observar regularidades e especificidades das condições ambientais de terras indígenas em contextos de diversidade fundiária. Isto resultou no estudo de uma terra como reserva e mais duas terras indígenas: uma regularizada e outra não. A partir daí, a escolha foi se refinando para terras com maioria kaiowá, que tivessem algum projeto de recuperação ambiental, como é o caso da reserva de Téýkue; que estivesse no contexto das terras cujos estudos de identificação e delimitação ocorreram na década de 1990, como Sucuruíy e que tivessem algo de emblemático como é o caso da história de luta pela retomada da terra de Jatayvary. Estão todas situadas em três municípios diversos no sul de MS, cujos processos de colonização são semelhantes.

$\mathrm{Na}$ construção do "como fazer", procurei conhecer metodologias para sair delas. Nos procedimentos metodológicos foram utilizados dados empíricos das terras em estudo e analisadas a situação fundiária e jurídica destas terras, em particular, através de relatórios de identificação e delimitação de terras indígenas e perícias antropológicas. Para os estudos de caso (YIN, 2010) foi realizado trabalho de campo com adoção de técnicas de observação direta, conversas, depoimentos gravados e transcritos, diários de campo, caminhadas, registro de fotografia, participação em encontros de professores indígenas e em uma Aty Guasu ocorrida em Yvy Katu, em julho de 2014. Cartograficamente, foram mostradas as representações que os professores fizeram de suas terras através de trabalho realizado em oficinas no Curso de Formação de Professores Ára Verá, que constitui um verdadeiro atlas pedagógico das terras indígenas ${ }^{6}$.

\footnotetext{
${ }^{6}$ Como diz o professor Joelson Pereira, na apresentação desse material, o atlas cumpre com os papeis de representação cartográfica, de comunicação e didático-pedagógico, pois revelam: "uma grande riqueza composta por recursos naturais representados por matas, solos, rios, nascentes, recursos minerais e pela biodiversidade, quanto a sua preocupação com temas que atualmente representam desafios a esta mesma comunidade, como aqueles relacionados às fragilidades ambientais como a erosão do solo, o assoreamento de rios, as queimadas, a supressão dos recursos florestais, a questão demográfica, dentre outros" (GUARANI HÁ KAIOWÁ, 2011, p. 9).
} 
O estudo situa-se como uma pesquisa de abordagem qualitativa através de estudo de caso de três terras indígenas situadas ao sul de Mato Grosso do Sul, com maioria de população kaiowá-guarani. A população de estudo está caracterizada através de grupos representativos de: idosos, rezadores, professores e lideranças. As principais fontes de dados são orais com base em conversações realizadas em trabalho de campo. Este trabalho dividiu-se em um campo prévio que serviu de base para a coleta dos dados da pesquisa da presente tese. O campo definitivo, realizado em agosto de 2014, consistiu na coleta de fontes orais, dos grupos de pessoas acima descritas, através de conversações realizadas em cada terra indígena por um período de uma semana em cada uma das três terras estudadas. Os dados coletados foram analisados conforme os objetivos traçados para a tese e conforme as especidades verificadas para cada uma das três terras indígenas estudadas.

Optei por não fazer entrevistas institucionais. Elas estavam inicialmente previstas no projeto de tese, mas resolvi abdicar deste repertório, pois, assumi que não queria trabalhar com as visões institucionalizadas e burocratizadas de órgãos que lidam com "as questões ambientais e indigenistas". Decidi valorizar as falas dos povos na sua terra, mesmo sentindo que diversas de suas ponderações se remetem a presença ou ausência de políticas, projetos e programas que direta ou indiretamente atingem as suas vidas. Nesse sentido, meu trabalho se aproxima mais da análise de percepções de grupos específicos. Com isso, afastei da centralidade do trabalho as possíveis comparações entre as visões institucionais e as realidades vivenciadas no dia-a-dia das terras e de sua gente.

A utilização das fotografias também constitui um rico material para interpretação da terra. Não são meras ilustrações. Estimulam sentidos e percepções e favorecem as análises de fatos descritos. A sua seleção constituiu uma tarefa árdua devido à farta disposição de imagens representativas das visões da terra e de sua gente que consegui captar. Por isso, estão dispostas ao longo de todo o corpo do trabalho não como coadjuvantes, mas como figuras centrais das análises realizadas. Todas as fotos são de autoria própria, feitas durante as visitas e trabalho de campo.

Em comum acordo com meu orientador, que desejava uma tese interdisciplinar com rigor acadêmico e com dimensão literária, optamos pela liberdade de usar a primeira pessoa em partes do trabalho. Por isso, a adoção da pessoa que fala no texto será o "eu" e o "nós". Não utilizarei o impessoal, prática frequentemente utilizada por mim no passado.

Foram realizados trabalhos de campo prévio em novembro e dezembro de 2013 em Sucurui'y e Jatayvary e em mais duas outras terras na condição de reivindicadas em que optei, posteriormente, em não prosseguir com os estudos devido ao tempo de pesquisa e a extensão da tese. Em agosto de 2014, realizei o campo mais aprofundado nas três terras que compõem este estudo: Te'ýkue, Sucuruíy e Jatayvary. Nesta ocasião, contei com a 
presença de dois informantes/tradutores. O trabalho de campo foi uma experiência transformadora e reveladora para mim.

A identificação das pessoas para o trabalho de conversação ocorreu prévia e concomitante a pesquisa de campo, assim como as caminhadas as diversas regiões que compõem as terras e aos lugares com presença de vegetação. Ao me apresentar a um grupo ou pessoa, procurei deixar claros os objetivos da pesquisa. Ressaltei a necessidade de conhecer por eles o que está acontecendo na terra e as dificuldades sentidas. As conversas revelaram momentos de rara beleza, com algumas passagens muito bonitas e com simplicidade. Busquei perceber a percepção das pessoas com quem dialoguei, tentando sentir com elas as transformações da terra e como isso as afeta a partir de contextos históricos das três terras indígenas estudadas no quadro geral das mudanças interétnicas e suas influências no modo de ser kaiowá.

Como do ponto de vista metodológico foi impossível percorrer todas as diversas realidades das famílias e dos sujeitos presentes nestes espaços, reforcei a visão das pessoas com quem compartilhei conversas e caminhadas, sabendo que as mesmas também estão inseridas em contextos mais amplos aos quais pertencem.

No informativo de trabalho de campo, busquei mapear as pessoas para conversar, através das categorias previamente definidas, como idosos, rezadores, lideranças e professores. Situando um pouco da sua trajetória de vida, idade, origem e tempo de permanência na terra.

A escolha das pessoas ocorreu a partir da análise dos contextos sociais aos quais elas pertencem, sendo que, também, exercem de diversas formas papeis de lideranças em suas comunidades. Então, professores, rezadores, idosos e lideranças políticas representam diversas percepções sobre suas relações com a terra. Estas categorias nem sempre são rígidas e as pessoas podem transitar exercendo diversos papeis em sua terra indígena.

Como no contexto de MS há terras em litígio e várias demandas pela regularização fundiária na região de estudo, optei pela não identificação dos nomes dos meus interlocutores. Então, suas falas serão marcadas pela categoria principal que representam. A cada início de capítulo fiz menção aos sujeitos com os quais realizei o dialogo.

A conversa com os professores ocorreu a partir do reconhecimento do exercício de uma certa centralidade na vida das terras indígenas, constituindo-se em novas lideranças, cuja presença pode ser sentida muito fortemente nas Aty Guasu. Hoje em dia, os professores são: promotores e parceiros de projetos ambientais e culturais a partir da escola; intermediadores do mundo entre os mestres tradicionais e as novas gerações, bem como entre instituições e pessoas do mundo não-indígena. 
A escolha de idosos, rezadores ${ }^{7}$ e mestres tradicionais se deu por serem detentores de conhecimentos; de histórias dos antigos; de uma memória sobre a mata e a terra, bem como, por melhor saberem e vivenciarem a cosmologia kaiowá-guarani. Além disso, são chefes de parentela.

Sobre as lideranças meramente políticas, a escolha recaiu sobre os caciques, como são mais chamados hoje em dia. Embora pese a transitoriedade do seu posto, foi revelada a sua atuação no momento em que foi feita a pesquisa de campo. Em muitos casos, sua frágil legitimidade revela dificuldades em solucionar conflitos internos.

Procurei manter um cuidado com a linguagem para entrar no universo do outro com uma fala mais apropriada. Por isso, foi constante a tentativa de evitar o uso de termos que fazem parte do ideário modernizante ambiental, mesmo sabendo que alguns termos ambientais já fazem parte do discurso de algum deles e possuem diversos significados. As ambiguidades terminológicas são recorrentes e quando apropriadas e resignificadas podem assumir uma plêiade de significados, dificultando assim a comunicação.

Sobre o modelo de conversas, o que prevaleceu foi à conversação livre. Mas através de algumas colocações e perguntas, introduzia temas na tentativa de chegar às informações recorrentes para cada grupo de pessoas. Procurei aproveitar as brechas e os silêncios para introduzir alguns dos temas que compõem o universo da pesquisa. Optei por não utilizar questionários ou entrevistas estruturadas ou semi-estruturadas. O roteiro estava aberto em minha cabeça, por isso, fluiu um processo livre na construção das conversações.

Fiz um roteiro prévio, com alguns temas que considerei importantes para a pesquisa. Mas o campo foi me guiando. E no momento das visitas, eu adaptava o roteiro de acordo com a relação que ia estabelecendo com o conversante. Às vezes, eles me levaram por caminhos que não havia imaginado e acabaram se revelando bastante ricos. Foram conversas abertas ao inusitado. No momento da construção do texto, aí sim, busquei rigor metodológico e regularidade na escolha das falas e temas ambientais para realizar as análises.

No roteiro geral de conversação, procurei captar através das falas dos meus interlocutores suas percepções sobre a terra, incluindo o meio ambiente, especialmente sobre manejo, saberes, ligação, pertencimento e memória. E, ainda, sobre as relações entre cosmologia e a situação atual, com as dificuldades e problemas enfrentados na terra.

As perguntas mais específicas giravam em torno de questões sobre: a) plantas, árvores, mata, remédios naturais, reza, caça, pesca e roça; b) queimadas; c)

\footnotetext{
7 "Na compreensão dos Kaiowá atuais, existem três categorias de pessoas envolvidas com o que denominam de 'tradição': a) o cacique verdadeiro, extremamente raro hoje em dia; b) o rezador, conhecedor parcial de modalidades de rezas e de sua aplicabilidade; c) o burlador, denominado de cacique ngua'u. o oposto do xamã verdadeiro é o xamã falso, conhecido como cacique ngua'u. (PEREIRA, 2004, p. 363).
} 
braquiária/colonião; d) como recuperar a mata e trazer os animais de volta e os jára (donos dos seres); e) rituais e cerimônias; f) educação escolar indígena; g) projetos de recuperação ambiental; h) impactos ambientais das atividades econômicas do entorno.

Situaria a minha interação com eles como um processo de sentir e perceber com eles as condições de vida e da terra, nos seus respectivos ambientes, compartilhando um pouco das suas vidas, repartindo algumas refeições e fazendo caminhadas. Por isso, procurei construir um texto privilegiando suas narrativas e destacando as suas falas, que estão cercadas de percepções, emoções, sentimentos, desabafos e esperança. Minhas análises e diálogos com pesquisadores dos temas também estão presentes, mas o destaque está nas falas dos meus interlocutores que permeiam todo o texto. Compondo assim, uma teia, um mosaico de percepções, sentimentos sobre suas vidas e dos seres visíveis e invisíveis que habitam as suas terras.

Nos momentos das ricas e adoráveis caminhadas emergiram a espontaneidade e a alegria ao mostrarem as espécies e seus saberes sobre elas. Foram momentos privilegiados de intensa beleza e de contentamento que vieram à tona em relatos orais, revelando suas trajetórias nos contextos étnicos, sociais, históricos e políticos que os cercam.

Devido ao fato de não saber a língua guarani, optei por contratar tradutores indígenas para intermediar a comunicação com as pessoas que não se expressam bem em português, principalmente com os mais idosos. Inicialmente, a ideia era ter um só tradutor para me acompanhar nas três terras pesquisadas, pois, tive que prepará-los sobre o meu "tema" e sobre os procedimentos adotados ao traduzir. Mas por questões de logística e dos compromissos assumidos pelo primeiro tradutor que me acompanhou em Jatayvary e em Sucurui'y, optei por contratar outro para Te'ýikue.

Mas, em algumas ocasiões, o tradutor se esquecia de mim e ficava travando diálogos maiores em guarani, sem qualquer tradução para o português. Nestes momentos, eu me sentia invisível. Algumas falas ou palavras foram perdidas nesse processo de conversação. Frequentemente, eu alertava ao meu tradutor da importância de fazer a tradução e do modo mais fiel possível a quem falava, ou seja, utilizando-se da primeira pessoa do singular e não da terceira. Esse aspecto constitui um dificultador para o pesquisador que não domina a língua das pessoas com quem se propõe a investigar.

Existem diversos níveis de como é falado o português pelos kaiowá-guarani com quem conversei, variando conforme a idade, a interação com o português e o grau de escolarização formal. Ficou claro que os mais velhos tem mais dificuldade de compreensão e de conversação no português. Da minha parte, percebi que a lógica da construção do pensamento e das ideias também apresenta diversos níveis de dificuldade no português. Algo que para mim se mostrava, no princípio, bem incompreensível, à medida que iria conversando mais e mais com a pessoa, passava a compreender melhor seu universo de 
fala e de organização de pensamento. Fato que foi se aperfeiçoando com as escutas posteriores das falas gravadas.

Pouco a pouco fui me aproximando do modo de falar de cada pessoa, identificando minhas dificuldades, abrindo meus sentidos, fazendo conexões e tentando cada vez mais entrar no universo das pessoas com quem conversei. Busquei uma abertura pelo diálogo, mas pelos propósitos da pesquisa procurei falar menos e escutar muito mais. Mesmo o que aparentemente eu percebia que utilitariamente não iria servir para a pesquisa, optei pela liberdade do momento da conversa para que em momentos posteriores (de escuta, reescuta, degravação, escrita, análise e escolha do texto) pudesse refletidamente fazer os refinamentos e as delimitações da pesquisa.

De fato, os tradutores fizeram parte da pesquisa. Ocorreu um aprendizado mútuo entre os universos da pesquisadora e dos tradutores/acompanhantes/informantes. Bem como certa cumplicidade e familiaridade com o decorrer do tempo. Houve também a constatação de como os episódios da vida particular deles influenciou o ritmo e o planejamento da pesquisa quando, por exemplo, ocorreu o nascimento do filho do primeiro tradutor ${ }^{8}$. No caso do tradutor de Te'ýkue, tivemos que pedir autorização ao pastor branco para o qual o rapaz prestava serviços caseiros, além de compatibilizar o seu tempo de atividades na igreja.

O primeiro tradutor, com pouco menos de quarenta anos, me acompanhou inicialmente para Jatayvary. Facilitou algumas conversações em guarani, mas devido a sua participação como membro da Aty Guasu, em vários casos, passou a desempenhar um papel de orientador dos encaminhamentos das demandas da comunidade e, eram muitas, devido à situação de terra em litígio, como se poderá perceber nas falas analisadas no capítulo 5. Apesar de tentar direcionar o assunto para as "questões da pesquisa", as reclamações, denúncias e pedidos de projetos sempre retornavam. Então, deixei fluir e dessa naturalidade, sempre brotavam temas direta ou indiretamente relacionados ao que eu buscava.

Segundo este tradutor, ele teve "muita novidade nesse trabalho de campo" e "aprendeu muita coisa". Despertou algumas curiosidades, por isso, sempre dizia que iria "perguntar mais pro tio e pra avó pra aprender". Para ele, é difícil recuperar a mata, mas é importante que quem saiba sobre o mato para remédio, ensine as crianças e aos jovens. Para ele: "quem não sabe pode até queimar e carpir o mato sem identificar o que é remédio". Demonstrou interesse em seguir pesquisando sobre plantas, rezas e remédios medicinais com seus parentes mais idosos. Assim como eu, fazia várias anotações sobre as

\footnotetext{
${ }^{8}$ Em um dos dias que iríamos para Jatayvary, ao pegá-lo na rodoviária de Dourados no horário combinado, ele disse que seu segundo filho havia nascido no dia anterior e que precisaria ir ao hospital para providenciar a documentação do registro da criança. Então, seguimos para o hospital da missão Kaiowá conforme ele havia indicado. Mas chegando lá, informaram que sua esposa não estava e, que estaria no Hospital Universitário. Ele estava muito confuso ao pedir informações. Seguimos para lá, onde ele encontrou sua esposa e filho.
} 
plantas e me apontava à escrita correta das espécies em guarani. Disse que seu pai sabia muita coisa, mas ele perdeu a oportunidade de aprender porque preferiu aprender coisas de branco.

Em Sucurui'y, este tradutor também me acompanhou e foi muito relevante para mostrar os caminhos e atalhos para se chegar a terra. Uma das professoras da escola é sua prima, o que também oportunizou as conversas. Foram ricos nossos diálogos nas longas jornadas diárias ao percorrer a distância entre sua casa e a chegada/saída das terras visitadas. Foi possível interagir sobre as diversas percepções dos nossos mundos ${ }^{9}$.

Já em Te'ýikue, me foi indicado um jovem de vinte e poucos anos, indígena da área de fronteira do Paraguai e, com um bom trânsito entre o português e o guarani. Ele já estava morando há alguns anos na região da Missão, fazendo parte da congregação religiosa existente lá e sendo aluno da escola de ensino médio na educação de jovens adultos. Ele conhecia bem os caminhos das várias estradinhas da reserva e por não ser de lá, transitou bem entre todas as pessoas com as quais conversamos.

\section{APRESENTAÇÃO DA TESE}

A perda dos territórios tradicionais tem provocado uma série de consequências danosas sobre a organização social dos kaiowá-guarani, em que se destacam os efeitos sobre: a segurança alimentar, a saúde, a economia, a perda do patrimônio genético de plantas, a escassez de animais de caça, os rituais culturais e religiosos associados às espécies animais e vegetais.

Além do aspecto central da regularização fundiária, existem outras pautas políticas manifestadas pelos kaiowá-guarani que começam a ganhar espaço, como as chamadas questões ambientais. A maior parte da literatura sobre os kaiowá-guarani está concentrada sobre a organização social, costumes, crenças e tradições numa perspectiva eminentemente antropológica e histórica. Para THOMAZ DE ALMEIDA (2001, p. 195), “a falta de terra parece representar o principal problema para os Guarani contemporâneos no MS". No entanto, com a discussão sobre a terra e para além dela há outras pautas reivindicatórias de direitos, políticas e serviços demandadas pelos kaiowá-guarani.

Mas, mesmo com toda a problemática fundiária, é nas terras indígenas regularizadas onde se encontram as melhores condições ambientais da região do sul do Mato Grosso do Sul, pois, observa-se que nas terras em que os kaiowá-guarani tiveram a retomada da

\footnotetext{
${ }^{9}$ Destaco uma longa conversa que tivemos sobre as dificuldades atuais de se fazer roça, que segundo ele se devem aos seguintes motivos: a presença do colonião/braquiária; a pouca terra; a dificuldade para fazer a coivara dos antigos; aos insetos e vetores que antes ficavam no mato; as sementes transgênicas, que também afastam os insetos, pois, eles fogem das plantações de transgênicos; as dificuldades com as sementes modificadas, já que delas não se pode plantar; ao solo fraco; a pouca quantidade de mato e de sombra, pois, algumas espécies dependem da sombra de árvores para crescer, como a abóbora.
} 
posse, tem havido uma recuperação natural destes espaços. Deixar o "mato crescer", como eles dizem, implica na volta de animais e de plantas aonde antes havia lavouras de monoculturas e pastagens de gado.

Contudo, percebe-se a existência, no interior das terras indígenas, de grupos com práticas totalmente distantes deste "ideário", que negociam com empresários rurais o arrendamento de terras para o plantio de cana-de-açúcar e até mesmo de soja transgênica. Contrariando, assim, o direito ao usufruto exclusivo dos recursos naturais e a posse permanente da terra pelos indígenas. Isto revela algumas das complexas situações fundiárias e de manejo que visualizei neste trabalho.

Procurei construir uma centralidade da tese em cada capítulo, ou seja, em todo o seu corpo e não apenas nas partes destinadas especificamente as três terras indígenas que constituem o estudo de caso. A intenção foi de construir um texto conciso de modo a tentar evitar repetições, divagações e informações ou análises que apenas margeariam o coração do trabalho.

O trabalho está dividido em cinco capítulos. Na disposição do primeiro deles, busquei firmar as bases conceituais. Aqui já estão presentes elementos que compõem a centralidade da tese, inclusive com falas e interpretações do trabalho de campo. Principalmente sobre temas gerais que atingem e compõem a realidade das terras estudas.

Verifiquei a necessidade de construir um tópico específico no capítulo 1 contextualizando sobre diversos temas que envolvem os Kaiowá-Guarani, revisando e abordando parte da ampla produção científica sobre os mesmos. No tópico 1.1 trato sobre: aspectos gerais da etnohistória, como ocupação tradicional e transformações ao longo de quase um século; a organização político-social; conceitos/categorias importantes como te'yi, tekoha e tekoha guasu; processos de luta; classificação das terras indígenas e aspectos fundiários. No tópico 1.2 reviso concepções sobre colonialismo e procuro atualizá-las para situações vivenciadas pelos kaiowá-guarani; faço uma leitura da PNGATI e do papel das terras indígenas para a proteção ambiental. Descrevo caminhos que levaram a destruição das matas e a outros problemas ambientais.

No capítulo 2 situo a sustentabilidade da vida na terra analisando as relações entre natureza e diversidade cultural. No tópico 2.1 analiso alguns sentidos de sustentabilidade e de desenvolvimento sustentável. E, também, sobre pertencimento, topofilia e vinculação ao lugar como categorias fenomenológicas importantes para situar o modo de ser kaiowáguarani na terra. No último item deste capítulo, trabalho a noção de resistência à destruição da terra e dos saberes. No tópico 2.2 discuto questões sobre ética da natureza e sobre a Terra como um ser vivo a partir das cosmologias de Gaia, Pachamama e Yvy. Nele estão presentes discussões sobre cosmologia kaiowá-guarani e a relação com a terra, em particular sobre a figura dos jara como donos dos seres na terra. 
$\mathrm{Na}$ tessitura dos demais capítulos sobre as três terras indígenas e sua gente, procurei atender as peculiaridades de cada uma delas, mas também seguir uma certa uniformização de conteúdo, em que estão presentes elementos sobre a) território e situação fundiária; b) aspectos socioeconômico e ambientais e c) percepções ambientais. Neste roteiro, sobre o primeiro dos tópicos, busquei situar a localização, fazer um breve histórico sobre a terra e os seus aspectos fundiários. Já sobre o segundo, procurei caracterizar questões socioeconômicas e ambientais, focando em dados sobre população, serviços disponíveis e condições ambientais. Quanto ao último dos enfoques, prevaleceu análises sobre percepções ambientais quanto ao uso dos recursos naturais, relações com a terra, cosmologia, memórias, convívio e sentimento de pertença com a terra.

Os capítulos 3, 4 e 5 são, respectivamente, sobre as Terras Te'ýikue, Sucurui'y e Jatayvary. Nestes, sigo certa regularidade, como já firmado, mas procuro atender as peculiaridades de cada uma das terras estudadas. No capítulo 3, sobre a Terra Te'ýikue, o destaque é a educação escolar indígena e o projeto de recuperação ambiental. Então, nesta parte, estes temas estão mais esmiuçados. No capítulo 4, sobre a Terra Sucuruíy, trato mais de questões sobre a relação com a mata e cosmologia. E, no capítulo 5, sobre a Terra Jatayvary, devido a sua situação fundiária e proximidade com os plantios de cana-deaçúcar, analiso aspectos referentes à forte influência do setor sucroalcooleiro nesta terra. 


\section{POVOS DA MATA NA TERRA SEM MATO}

\subsection{OS KAIOWÁ-GUARANI}

\subsubsection{O povo e sua terra}

"Os nossos antepassados contavam que no Mato Grosso do Sul tinha mato, macaco, bicho". Esta fala de um professor de Sucurui'y releva um paradoxo vivido pelas atuais gerações de kaiowás no MS: uma memória do que era a terra, de um tempo que se foi e, de uma agora, vida com escassez de mato e dos seres que a habitam. No entanto, a imaginação do passado remoto e o que pode vir a ser um lugar repovoado com variedade de vida inspira a resistência dos seus saberes sobre a terra resiliente.

O estado de Mato Grosso do Sul possui a segunda maior população autodeclarada indígena no Brasil ${ }^{10}$ e abriga sete etnias no seu território: Guarani; Terena; Kadiwéu; Ofaié; Guató; Kinikinau e Atikum. Os Guarani que vivem neste estado pertencem a dois subgrupos: os Kaiowá ${ }^{11}$ e os Ñandeva, sendo os primeiros constituintes da maior população indígena no Mato Grosso do Sul. Tradicionalmente, o território Kaiowá, marcado por "matas, córregos e terra boa para a agricultura", se estendia "ao norte, até os rios Apa e Dourados e, ao sul, até a Serra de Maracaju, abrangia uma área de cerca de 40 mil quilômetros quadrados no Brasil e Paraguai" (MONTEIRO, 2003, p. 18).

O termo guarani é uma identidade atribuída a povos que falavam idiomas, história e culturas semelhantes. Como lembra Barth (2011, p. 195): "os grupos étnicos não são simples ou necessariamente baseados na ocupação de territórios exclusivos; e os diferentes modos pelos quais eles se conservam, não só por meio de um recrutamento definitivo, mas por uma expressão e validação contínuas, precisam ser analisados".

O povo guarani está presente no que hoje corresponde aos Estados Nacionais do Brasil $^{12}$ (Kaiowá, Ñandeva/Guarani e Mbyá), da Argentina (Mbyá e Chiriguano), do Paraguai (Paĩ-Tavyterã, Avá-Chiripá/Avá-Katuete, Mbyá e Ache-Guayakí) e da Bolívia (Chiriguano (Avá, Simba, Isoso e Guarajo) (CHAMORRO, 2009, p. 75).

\footnotetext{
${ }^{10}$ O Estado brasileiro com maior população indígena é o Amazonas, com 168.680 índios autodeclarados, seguido de Mato Grosso do Sul, com 73.295, o que corresponde a 3\% da população total do Estado e a $9 \%$ da população indígena total no país. Segundo os resultados do Censo Demográfico do IBGE de 2010, houve um crescimento populacional indígena no país em relação a 2000, revelado pelo ritmo de 1,1\% ao ano (IBGE, 2014). ${ }^{11}$ Há várias nomenclaturas encontradas na literatura, como "Cayuá, Cainguá, Caiowá, Caingá, Caiguá, Kaioá" (GALVÃO, 1996, p. 177). Ou, ainda, “Kayguá, Kaÿguá, Ka’yguá, Ka'ynguá, Kainguá, Cainguá, Caaguá, Caaingua, Canguá, Cayagua, Cagoa, Cayoa, Caygoa, Cayowa, Caingua, Caa-owa, Cayuás, Cayuáz" (CHAMORRO, 2014, p. 17).

${ }_{2}^{2}$ No Brasil, estão nos estados do Rio Grande do Sul, Santa Catarina, Paraná, Mato Grosso do Sul, São Paulo, Rio de Janeiro e Espírito Santo.
} 
"No início do século XVI, os índios da América estão ali, bem presentes, mas deles nada se sabe, ainda que como é de esperar, sejam projetadas sobre os seres recentemente descobertos imagens e ideias relacionadas a outras populações distantes" (TODOROV, 2010, p. 5). O encontro com o outro, com o diferente, veio a alterar definitivamente o destino das Américas. Chamorro (2014, p. 25) apresenta:

registros que atestam a ocupação do atual Mato Grosso do Sul pelo grupo étnico autodenominado kaiowa há aproximadamente duzentos anos, bem como a dos seus parentes no nordeste paraguaio, autodenominado PaĩTavyterã. Mas, como a presença de indígenas falantes de guarani na região é documentada por escrito desde o século XVI, os povos kaiowa ou paĩtavyterã contemporâneos podem ser considerados descendentes biológicos dos indígenas que habitam, pelo menos, entre 1500 e 2000 anos na região.

Batalla $(1970$, p. 6, 11) ressalta que "a categoria de índio denota a condição de colonizado e faz a referência necessária à relação colonial", tendo no processo de conquista a sua diversidade anulada. Forma-se a partir daí a figura do "índio genérico" em contraposição ao sujeito com suas particularidades. Nesse sentido, ele prossegue: "a invenção do índio, o que é o mesmo, a implantação do regime colonial na América, significa um rompimento total com o passado pré-colombiano". Nos sistemas coloniais, este índio tem suas terras espoliadas, é usado como mão de obra e suas ordens social e cultural são alteradas pelo colonizador.

Numa brevíssima linha do tempo, os Paĩ-Tavyterã do Paraguay e os Kaiowá do Brasil são considerados descendentes dos Caaguá, que por sua vez provêm de uma continuidade dos Itatin. Os Itatin se localizavam ao norte de Assunção e mantinham algum contato com os colonizadores espanhóis desde antes da fundação desta cidade (MELIÁ, GRÜNBERG, GRÜNBERG, 1976, p. 157). Mas segundo SUSNIK (1979, p. 28-9), "el protohabitat itatí no representaba ventajas potenciales para el cultivo por rozado, de donde las primeras tendências del "ogwatá" expansivo hacia el sureste rumbo a los ríos Amambay e Ygatemí". Com o contato com os jesuítas, a partir de 1632, parte dos Itatin é reduzida. "Consta dos relatos dos missionários que o argumento que os convenceu a se reduzir foi a perspectiva de fugir da dominação espanhola” (BRAND, 1993, p. 17). Para Meliá, Grünberg, Grünberg (1976, p. 168), no século XVIII, os Caaguá "son los Itatin, pero conceptuados nuevamente por el proceso colonial: los caagua son aquellos Itatin no colonizados ni missionados, pero en contacto com la colónia y la misión: ahí, estribaria su identidade y su diferencia".

Os diferentes momentos do processo de colonização de Espanha e de Portugal, das missões jesuítas e outras que se seguiram, da formação dos estados nacionais e da implantação de políticas públicas foram responsáveis por profundos impactos na vida das sociedades indígenas. A organização social guarani é baseada na família extensa ou parentela percorrendo unidades de menor para maior abrangência, chamadas de: tekoha e tekoha guasu. 
Um conceito-chave para se compreender a organização social é o de te'ýi, que representa a família e sua descendência. O te'ýi "é estruturado a partir da aglutinação de parentes consanguíneos e afins em torno do cabeça de parentela - híu, geralmente um homem de idade avançada que gerou muitos filhos" (PEREIRA, 1999, p. 86). A família extensa é formada por várias gerações: avôs, pais, filhos e netos que, no passado, residiam numa única habitação grande (oygusu). Os parentes, ao morarem juntos, exercem a economia da reciprocidade em todos os níveis, havendo uma articulação social, política e religiosa em um território. Para Pereira (1999, p. 92), é praticamente impossível ser kaiowá sem parentes e "a análise do parentesco kaiowá nos permite afirmar que viver na parentela te ýi é a condição para a realização de seu modo de ser - teko".

Cada te yi "revela uma série de liames a cimentar um leque variável de relações entre um conjunto de casas formando uma espécie de aglomerado em torno de um centro político, ocupando uma determinada porção do território de uma área indígena" (PEREIRA, 1999, p. 85,6). Neste sistema, prevalece a autonomia das famílias extensas, tendo a presença de um líder político e religioso, em que sua moradia se distancia em alguns quilômetros de outra família extensa.

Outro conceito importante é o de fogo familiar (che ypyky kuera), que consiste em uma "unidade sociológica no interior do grupo familiar extenso ou parentela, composto por vários fogos, interligados por relações de consanguinidade, afinidade ou aliança política. $O$ pertencimento a um fogo é pré-condição para a existência humana na sociedade kaiowá" (PEREIRA, 1999, p. 81).

Os tekohas são os locais onde ocorre a produção material e cultural dos Guarani. Teko significa "modo de ser" e ha é o local. Etmologicamente, Tekoha é o local onde se realiza o modo de ser Guarani. Para Meliá, Grünberg, Grünberg (1976, p. 218) é:

el lugar en que vivimos según nuestras costumbres, es la comunidad semiautónoma de los Paĩ [Kaiowa]. Su tamaño puede variar em superficie (...) y en la cantidad de familias (de 8 a 120, en los casos extremos), pero estrutura y función se mantienen igual: tienen liderazgo religioso propio (tekoaruvicha) y político (mburuvicha, yvyra'ija) y fuerte cohesión social.

A partir desta concepção, cada pesquisador procura refletir sobre a ideia de tekoha, ressaltando algum aspecto ou fazendo sínteses, de modo a atualizar o conceito de acordo com os tempos e desafios vividos. Para Thomaz de Almeida (2001, p. 19):

é o lugar físico, a terra, o mato, as águas, o campo e tudo que ali existe, onde se realiza o sistema, o modo de ser, a cultura, o estado de vida guarani (...) cada grupo familiar tem no 'lugar', no Tekoha, sua história e sua referência primeira no mundo, e através dele entenderá os outros 'lugares' e sociedades, o que põe em relevo a situação local na constituição dos indivíduos e grupos familiares.

Já para Pereira (1999, p.84), tekoha "pode ser entendido como o lugar (território), no qual uma comunidade kaiowá (grupo social composto por diversas parentelas) vive de 
acordo com sua organização social e seu sistema cultural." Na sua visão, o tekoha "se refere mais a uma unidade político/religiosa, que comporta grande dinamismo em termos do número e da forma de articulação das parentelas que entram na sua composição, tendendo a assumir uma configuração flexível e variada" (PEREIRA, 1999, p. 95).

Reforçando a ideia desta categoria nativa, Thomaz de Almeida (2005, p. 38) procura ver o tekoha como resultado e não como determinante. Isto implica em "um processo continuado de ajustamento situacional em torno à determinação de uma relação territorial entre índios e brancos". Assim sendo, para o autor: "o tekoha seria uma unidade política, religiosa e territorial, que deve ser definida em virtude das características efetivas materiais e imateriais - de acessibilidade ao espaço geográfico por parte dos índios em pauta".

Mura (2006, p. 121) situa o tekoha em um "contexto sócio-ecológico-territorial". Então, o considera "como uma unidade política, religiosa e territorial, onde este último aspecto deve ser visto em virtude das características efetivas - materiais e imateriais - de acessibilidade ao espaço geográfico, e não de mera projeção de concepções filosóficas pré-constituídas".

Em um trabalho mais recente e refletindo sobre os processos de reivindicação de terras indígenas guarani-kaiowá, Cavalcante (2013, p. 80), analisa criticamente os sentidos de tekoha elencados acima e afirma concordar:

parcialmente com Mura, no sentido de que a categoria tekoha ganhou ênfase no discurso indígena como espaço territorial exclusivo de um grupo de famílias extensas (aldeia) a partir do momento em que os Guarani e Kaiowa, por força da situação histórica por eles vivenciada, foram obrigados a lutar politicamente pela demarcação de terras indígenas. Por outro lado, Pereira, embora dê ênfase nas relações que configuram um tekoha, também sinaliza nesse sentido ao afirmar que o espaço físico é de suma importância para a realização histórica do tekoha.

O termo admite muitos sentidos, sendo reforçado por um ou mais dos complexos elementos que o compõem de acordo com o momento histórico vivido. Na minha percepção é um conceito-base para se entender a organização social kaiowá-guarani composto por uma rede de relações sócio-políticas, afetivas e espirituais dentro e fora do espaço geográfico de uma terra indígena (reconhecida pelo Estado).

Numa perspectiva mais ampla, os tekoha guasu compõem um mosaico de tekohas. No passado, "sua característica principal era ser um território contínuo, sem barreiras físicas, a jurisdição exclusiva sobre uma micro-região (ou parte dela) construindo-se a partir de regras de parentesco e de alianças políticas (MURA, 2006, p. 131). Na mesma linha, Tonico Benites (2013, p. 258) entende como sendo um "espaço territorial amplo de uso de várias famílias extensas (conexão de tekoha) em rede que inclui diversos espaços de caça, de pesca, de coleta, de habitação e de ritual religioso, constituindo-se em palco de redes de relações intercomunitárias". 
Para contextualizar as transformações ocorridas na organização sócio-política e nas terras kaiowá-guarani tomarei como ponto de partida o fim da guerra da Tríplice Aliança, onde serão ressaltados os principais acontecimentos econômicos e políticos nos tekohas do cone sul de MS. Partirei de contextos mais amplos para situar as três terras que compõem o presente estudo.

\subsubsection{Singularidades fundiárias ao sul de MS}

A redefinição das fronteiras entre Brasil e Paraguai com o fim da guerra da Tríplice Aliança $^{13}$, no fim do século XIX, veio a marcar a nacionalidade dos Kaiowá e dos PaĩTavyterã, que até então circulavam em seu território tradicional com mobilidade. Seu vasto território começa paulatinamente a ser ocupado por grandes, médios e pequenos empreendimentos levados a cabo ao largo de mais de um século, cuja titularidade passa a ser legitimada através de cadeias dominiais oficializadas por cartórios imobiliários, com o aval do estado brasileiro. Concomitantemente, é construída uma política estatal indígena que teve no seu nascedouro a ideia de integração e assimilacionismo dos povos indígenas a nação brasileira.

O primeiro dos grandes empreendimentos foi a Companhia Matte Larangeira que constituiu-se em um imenso latifúndio através do arrendamento de terras de ocupação tradicional guarani-kaiowá ao formar um monopólio para a exploração de ervais nativos. Após o término da guerra do Paraguai, uma comissão para fixar os limites percorreu a região e um dos seus integrantes Thomaz Larangeira observou a farta disponibilidade de ervais nativos. Em 1882, o governo federal Ihe permitiu o arrendamento de terras públicas para a exploração por um período inicial de dez anos e um ano depois, ele funda a Companhia Matte Larangeira, abrangendo uma área impressionante de aproximadamente 5.400.000 ha. A área foi sendo ampliada graças ao seu bom trânsito político. A incidência deste arrendamento teve forte influência sobre as terras guarani-kaiowá e os indígenas foram utilizados como mão-de-obra (BRAND, 1993, p.47).

A Companhia constituiu um poderoso monopólio e, com isso impediu a entrada de outros colonizadores. Em 1912 houve resistência para a renovação dos arrendamentos, mas mesmo assim, 1.440 .000 ha foram renovados. A partir deste período lotes de terra começaram a ser liberados a outros empreendimentos. O domínio da Companhia perdurou

\footnotetext{
${ }^{13}$ Entre Brasil, Argentina, Uruguai contra o Paraguai, no período de dezembro de 1864 a março de 1870 , conhecida como a Guerra do Paraguai. Segundo Vietta (2003, p. 40), "a guerra com o Paraguai mostrou ao governo brasileiro a necessidade de investir mais no incremento do povoamento, na geração de alternativas econômicas e na agilização da comunicação com a região de fronteira. Para isso deu início a pesados investimentos voltados para a construção de ferrovias, desenvolvimento da navegação fluvial e implantação de comunicação telegráfica. Comandada pelo marechal Cândido Mariano da Silva Rondon, a Comissão Construtora de Linhas Telegráficas de Mato Grosso (1900-1930) foi responsável por estender a linha ao longo da fronteira com o Paraguai e a Bolívia e mais ao norte, além de construir estradas e pontes ligando as estações".
} 
até 1943: "quando o então presidente da República, Getúlio Vargas, cria o Território Federal de Ponta Porã e anula os direitos de Companhia Mate Laranjeiras" (BRAND, 1993, p. 51 54). Os argumentos desta política foram o de povoar e atender à segurança nacional. Embora, de um modo geral, muitos autores, considerem baixo o impacto sobre o modo de vida guarani-kaiowá ${ }^{14}$ e sobre as condições ambientais em relação aos ciclos econômicos que se seguiram, há que se analisar os comentários de Moreira da Silva (2002, p. 24):

A estrutura gigantesca da empresa sobre o espaço físico Kaiowá e Ñandeva foi implacável. Embora a Matte Larangeira não fosse a proprietária da terra e os contratos de arrendamento possuíssem cláusulas referentes à conservação das matas, constatou-se o desmatamento para criação de gado e à medida que eram feitos os deslocamentos dos ervais esgotados para outros inexplorados, um rastro de destruição no habitat dos índios Kaiowá e Ñandeva era deixado, tornando-se irreparável.

No ano de 1943, foi implantada a Colônia Agrícola Nacional de Dourados ${ }^{15}$, situada na política de "marcha para o oeste", de colonização de terras e de produção de alimentos, com a atração de assentamentos de trabalhadores através da venda de lotes para colonos. A CAND ampliou o raio de desmatamento e provocou impactos significativos sobre os tekohas, principalmente os de Panambi e Panambizinho.

Silva (1982, p. 11) situa que a CAND provocou ampla destruição das matas. No início da década de 80 , por ocasião da sua dissertação, relatou que: "existiam algumas pequenas ilhas de mata na aldeia do Posto Indígena Dourados e na aldeia de Lagoa Rica. Dificilmente se encontra uma árvore da antiga mata sub-tropical: a paisagem é dominada por plantações de soja, arroz ou algodão conforme a época do ano, ou então por pastos".

Em 1910 foi criado o Serviço de Proteção aos Índios e Localização de Trabalhadores Nacionais (SPILTN), que em 1918 passa a ser Serviço de Proteção aos Índios $\left(\mathrm{SPI}^{16}\right)$, com um escritório no então estado de Mato Grosso, cuja missão era delimitar áreas, através da criação de reservas, para alocar a população indígena e assim, liberar os demais espaços para a colonização de espaços e povoamento da comunidade nacional. Este órgão utilizou várias estratégias para transformar os indígenas em trabalhadores rurais e sedentarizados, partindo da "ideia de que "os indíos" eram um estrato social concebido como transitório, futuramente incorporáveis à categoria dos trabalhadores nacionais" (LIMA, 1995, p. 120).

\footnotetext{
${ }^{14}$ Conforme Brand (1993, p. 76), "curiosamente, tanto no Paraguai como no Brasil, as grandes empresas de exploração de recursos naturais (erva-mate e madeireiras), instaladas dentro do território $\mathrm{P} / \mathrm{K}$, apesar da violenta exploração de mão-de-obra, acabaram sendo fator de resguardo de grande parte deste mesmo território, por impedirem projetos de colonização na região, que poriam em risco seu monopólio".

${ }^{15}$ Segundo Vietta (2003, p. 51-2): “(...) o projeto embutido na proposta de colonização varguista transformou terra em objeto de especulação financeira e política, atendendo interesses nem sempre legítimos. No atual Mato Grosso do Sul, em menos de 20 anos, a maior parte das terras kaiowa e guarani foram privatizadas. $O$ objetivo de transformar o núcleo da CAND em um centro urbano foi alcançado, do ponto de vista do contingente populacional e da produção econômica, pois Dourados rapidamente se colocou como o segundo município do estado em ambos os aspectos".

${ }^{16}$ O SPI foi extinto em 1966, sob acusações de corrupção e, substituído pela FUNAl, em 1967, esta por sua vez, passou por uma significativa reestruturação em 2009.
} 
As reservas desorganizaram os tekohas, pois, artificializaram espaços que nem sempre constituíam uma ocupação tradicional das famílias extensas. A partir daí toda uma conjuntura de controle pelo Estado foi formada, de modo a desestruturar social, política e religiosamente a sociedade kaiowá-guarani. O poder de tutela exercido pelo SPI tem sua expressão máxima na criação de reservas indígenas, que segundo a análise de LIMA (1995, p. 76), são:

Porções de terra reconhecidas pela administração pública através de seus diversos aparelhos como sendo de posse de índios e atribuídas, por meios jurídicos, para o estabelecimento e a manutenção de povos indígenas específicos. Territórios definidos às custas de um processo de alienação de dinâmicas internas às comunidades étnicas nativas compõem parte de um sistema estatizado de controle e apropriação fundiária que se procura construir como de abrangência nacional. Sua finalidade é disciplinar o acesso e utilização das terras, ao mesmo tempo mediando sua mercantilização, aplicando-Ihes sistemas de registros e cadastramento (procedimento que não se impõe sem conflitos entre os inúmeros aparelhos de poder estatizados), às diversas unidades sociais surgidas historicamente $\mathrm{da}(\mathrm{s})$ conquista(s).

Foram criadas oito reservas ${ }^{17}$, entre os anos de 1915 e 1928, cuja finalidade era alocar toda a população indígena desta região, cuja localização levava em consideração a maior concentração de indígenas, foram elas: Amambai (Benjamim Constant), Dourados (Francisco Horta), Caarapó ou Te'ýikue (José Bonifácio), Sassoró ou Ramada, Limão Verde, Porto Lindo ou Jakare'y, Takuapiry e Piraju'y. Os decretos instituidores das reservas determinaram a extensão de 3.600 ha, mas ocorreram reduções no procedimento demarcatório ou posteriormente.

Com o passar das décadas, as reservas foram recebendo populações vindas de outras localidades, ocasionando assim um superpovoamento em relação ao espaço disponível para desenvolver atividades de agricultura e de acesso a condições ambientais adequadas. Muitos indígenas foram atraídos pela possibilidade de acesso a serviços prestados pelo SPI e pelas missões religiosas que começavam a se instalar no interior ou nos arredores das áreas reservadas.

Uma intervenção muito marcante sobre a organização social ocorreu com a introdução da figura do capitão nas reservas, que passou a ser o intermediário entre o órgão indigenista e os indígenas em reserva. $O$ mburuvicha ou tekoaruvicha ${ }^{18}$ de cada tekoha passou a ser substituído por uma liderança para todas as famílias extensas, modificando assim, a estrutura tradicional e provocando inúmeros conflitos.

\footnotetext{
${ }^{17}$ Para Brand (2001, p. 119): "analisando a localização dessas oito reservas, ressalta-se que aquelas em áreas de cerrado não eram aldeias tradicionais (Limão Verde, Ramada e Caarapó). Tradicionalmente, as aldeias kaiowá/guarani localizavam-se em locais próximos a córregos e em áreas aptas para agricultura".

18 "O tekoaruvicha, líder religioso, sacerdote ou xamã, costumava muitas vezes acumular a liderança religiosa e política, juntando o "domínio" do sobrenatural com o prestígio próprio do político" (BRAND, 2003, p. 96).
} 
A criação das reservas gerou dois movimentos assimétricos que estão interligados: o confinamento e o esparramo. Inicialmente, Brand (1993, p. 5) entendeu o confinamento compulsório como sendo: "o processo induzido ou forçado de abandono dos tekoha (aldeias) originários e de concentração dentro das reservas demarcadas pelos governos de cada país". Posteriormente, no período de implantação das fazendas, entre as décadas de 1950 e 1970, ocorreu o esparramo (sarambipa), significando: "o processo de dispersão das aldeias e famílias extensas, provocado pela perda de terra e pela implantação das fazendas de gado" (BRAND, 1997, p. 5). Depois, Brand (1997, p. 5) entendeu que o confinamento também compreende a fase de concentração nas reservas com: "a conclusão do processo de implantação das fazendas de gado e correspondente desmatamento do território tradicional". Os dois movimentos provocaram profundos impactos para as famílias extensas.

Alguns dos impactos da vida em reservas podem ser sentidos: pela desestruturação de tekohas originários e dos laços de parentesco; pela mudança da chefia tradicional e da economia da reciprocidade; pela introdução do capitão e do assalariamento; pela inviabilização da prática do oguatá ${ }^{19}$, ou seja, pela inviabilização do modo de ser kaiowá (teko porã).

Muitas famílias resistiram em não ir para as reservas ${ }^{20}$ e permaneceram nos fundos de fazendas. Essa permanência próxima aos tekohas tradicionais nos fundos de fazenda foi chamada de tekoha refúgio. Até a década de 1970: "os kaiowá/guarani continuaram buscando o refúgio no interior das matas ou nos fundos das fazendas. Foi a forma encontrada para resguardar seu modo-de-ser próprio" (BRAND, 1997, p. 105-6). Nos anos 1980, praticamente ocorreu o fim do tekoha refúgio nos fundos de fazenda devido ao cerco do desmatamento e ao movimento de recuperação de tekohas (BRAND, 1997, p. 205).

A partir dos anos de 1970 e 1980 com o movimento dos guarani-kaiowá de reconquista das suas terras, intensificou-se a expulsão das famílias extensas que permaneciam nos fundos de fazenda, pois, os fazendeiros temiam perder suas propriedades. O temor se intensificou principalmente depois da demarcação de Guaimbé e

\footnotetext{
${ }^{19}$ A prática do oguata (caminhar ou peregrinar) no território ocorre devido a diversas causas que vão desde desentendimentos internos, acusações de feitiço, doenças ou mortes de parentes até o desgaste da terra e dificuldades de subsistência. Entendo que esta prática pode ser vista como um comportamento positivo do ponto de vista ambiental. Antes da chegada das frentes econômicas a prática poderia ser realizada, hoje, porém, devido ao quadro de situações fundiárias e devastação ambiental se tornou algo praticamente inviável.

${ }^{20}$ Barbosa da Silva (2009, p. 4) analisa que o uso e a ocupação territorial guarani-kaiowá ocorre na aldeia, na fazenda e na cidade, onde, as lógicas culturais são atualizadas. Devido aos diversos processos coloniais há uma adaptação e interligação das famílias nucleares formando a família extensa. Por isso, "não é apropriado se falar de "índio de cidade", ou "de fazenda", mas de índios na cidade ou na fazenda, ou ainda, como se pode claramente constatar hoje em dia, em beiras de rodovias, levando-se em conta necessariamente os sentidos que os próprios sujeitos atribuem para seus deslocamentos e estabelecimentos, nos contextos em que se encontram".
} 
Rancho Jacaré ${ }^{21}$, as primeiras terras a serem reconhecidas após 1928. Para Thomaz de Almeida (2005, p. 39) os tekohas reivindicados: "representam a soma de espaços de ocupação tradicional sob jurisdição de determinadas famílias extensas onde serão estabelecidas relações políticas comunitárias e a partir dos quais se determinarão laços intercomunitários numa região mais ampliada".

A reconquista de terras tradicionais a partir da década de 1980 se relaciona com o movimento Aty Guasu, com os movimentos sociais de redemocratização e com a conquista de novos direitos constitucionais em 1988. No princípio, a Aty Guasu era uma reunião para tomada de decisões entre os guarani-kaiowá com momentos de rituais sagrados e profanos numa atmosfera de encontro e troca de saberes. A partir dos anos 1980 emerge como um movimento com a finalidade de recuperação de tekohas. Este início foi apoiado pelo $\mathrm{PKN}^{22}$ e pelo CIMI.

A Aty Guasu - Grande Assembleia Guarani - é formada por um conselho que reúne vários representantes de terras indígenas onde são discutidos temas conforme a conjuntura política do momento. Tonico Benites $(2013,181)$, ressalta que a Aty Guasu é "composta pelos líderes políticos, os líderes espirituais (ñanderu e ñandesy) e seus aprendizes (yvyra'ija), e, sobretudo pelas crianças, mulheres e homens pertencentes às várias famílias indígenas".

É escolhida uma terra para o encontro, com duração, geralmente, de quatro dias e a Aty Guasu, começa com uma oração conduzida pelos xamãs/rezadores. Sendo seguida de discussões de temas, cujo registro é feito numa ata, que, ao final são feitos encaminhamentos a autoridades responsáveis, estas também convidadas a assistir e/ou falar na reunião. Nos últimos anos ${ }^{23}$, foram criadas Aty Guasu específicas como a Aty Guasu das mulheres e a Aty Guasu dos jovens.

Para Pimentel (2012, p. 242-3), a Aty Guasu seria hoje uma "instância representativa dos kaiowá e guarani, conforme reconhece a Convenção 169 da OIT", sendo também "explícita a intenção didática, de compartilhar experiências, motivar os mais novos e, sobretudo, orientar os grupos locais que tomaram há menos tempo a decisão de recuperar suas terras de origem". É um espaço de discussões políticas, discursos, troca de experiências de vida, relatos históricos, rituais religiosos e festivos. "É um lugar de transmissão de saberes" (BENITES, 2013, p. 182).

\footnotetext{
${ }^{21}$ A Terra Indígena Guaimbé, foi demarcada em 1983 e, homologada através do Decreto Presidencial n. 89.850 , de 24 de abril de 1984 e a Terra Indígena Rancho Jacaré, também em 1983 e homologada pelo Decreto Presidencial n.. 89.422, de 8 de março de 1984 .

${ }_{22}$ Projeto Kaiowá Ñandeva, de apoio à produção agrícola nas terras indígenas. Vide Thomaz de Almeida (2001).

${ }^{23} \mathrm{Na}$ Aty Guasu prevalecem os debates sobre a recuperação de tekohas, mas outros temas também fazem parte das discussões como saúde, educação, assistência social, violência, agricultura e meio ambiente. Em julho de 2014, acompanhei uma Aty Guasu na terra indígena de Yvy Katu em que foi proposto separar os grupos de debate de acordo com as terras em litígio e as terras regularizadas.
} 
Desde o início das Aty Guasu, os cantos, as rezas e a participação dos rezadores/as têm tido uma importância significativa. Como diz Tonico Benites (2013, p. 206), "o Aty Guasu foi e é vital pra a manutenção de modo de ser e viver (Ava reko) do GuaraniÑandeva e Kaiowá, rearticulando as práticas dos jeroky (rituais religiosos) e kotyhu/guachire (rituais profanos) Guarani e Kaiowa em rede, no seio do Aty Guasu". Estes aspectos fortalecem a etnicidade indígena a coesão entre as famílias e tekohas (BENITES, 2013, p. 191).

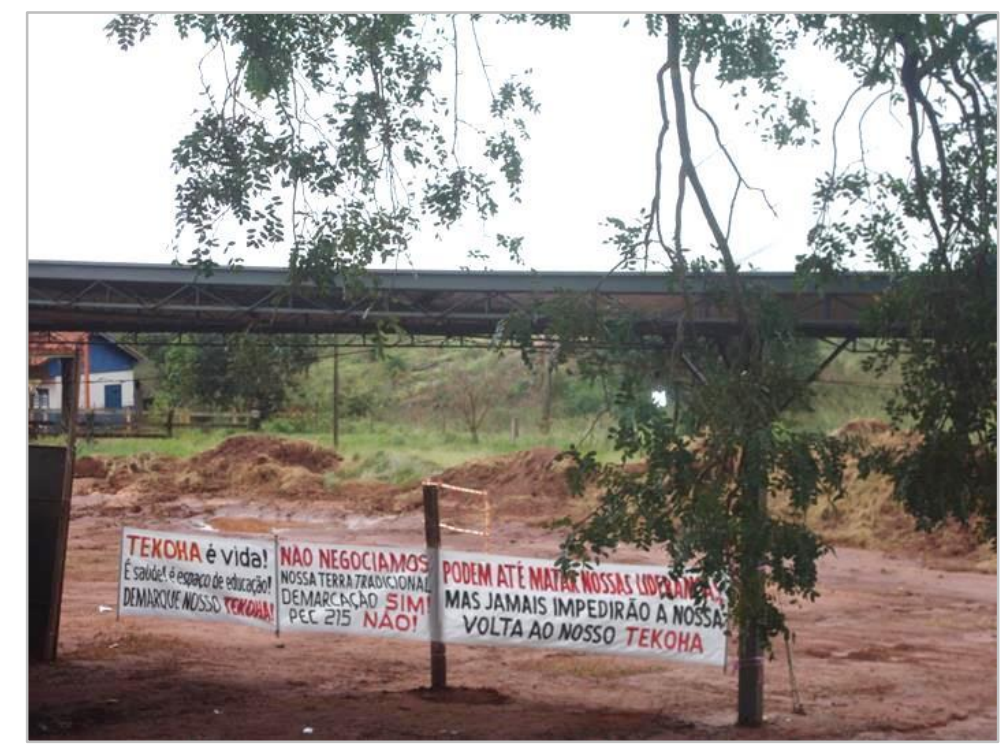

Fotografia 1 - Faixa pela demarcação no Aty Guasu em Yvy Katu, 2014. Fonte: Autoria própria.

A partir da década de 1980, vieram as demarcações de outras terras. O quadro é composto por vinte e duas terras indígenas conforme sistematização de dados de Cavalcante (2013, p. 95-6). Sendo nove registradas, ou seja, já regularizadas: Sucuríy, Panambizinho, Pirakua, Rancho Jacaré, Guaimbé, Jaguari, Guasuti, Cerrito e Jaguapiré. Cinco terras homologadas: Arroi-Korá, Jarará, Ñande Ru Marangatu, Cete Cerros e Takuaraty/Yvykuarusu/Paraguasu. São duas terras demarcadas: Yvy-Katu e Potrero Guasu. As declaradas são quatro terras: Guyraroká, Jatayvary, Sombrerito e Taquara. E duas terras na fase de identificação e delimitação: Panambi/Lagoa Rica e Iguatemipegua I.

As terras indígenas constituem uma categoria jurídica, que são vinculadas "ao cumprimento dos direitos indígenas sobre elas, reconhecidos pela Constituição como direitos originários (art. 231), que, assim, consagra uma relação jurídica fundada no instituto 
do indigenato ${ }^{24}$, como fonte primária e congênita da posse territorial" (AFONSO DA SILVA, 2008, p. 95). Esse constitucionalista vai além e entende que o reconhecimento da posse permanente das terras indígenas "independe da sua demarcação", cabendo a FUNAI assegurá-la atendendo "à situação atual e ao consenso histórico", pois, "o direito dos índios e da comunidade indígena que a ocupa, existe e se legitima independentemente do ato demarcatório" (Idem).

A demarcação "é um ato declaratório", ou seja, "não constitui nada, não cria nem extingue direitos, reconhece apenas a situação de fato e o direito correspondente". Está vinculada aos preceitos constitucionais, devendo atender a critérios de integridade e continuidade. Neste sentido, Afonso da Silva (2008, p. 98-109) percebe que a demarcação de terras indígenas em ilhas "causou terríveis danos aos índios, destruindo-os praticamente, como se deu com os guaranis de Mato Grosso do Sul". Os títulos de propriedade de imóveis das terras reconhecidas como indígenas são nulos e extintos, sendo indenizáveis as benfeitorias de boa-fé (art. 231, §6ํ da CF/88). O questionamento sobre estes valores geralmente é feito judicialmente. A retirada dos antigos ocupantes é chamada de extrusão e nem sempre é um procedimento tranquilo.

A demarcação de terras indígenas tem como base o art. 231 da Constituição de 1988 e a lei $6.001 / 73^{25}$ (Estatuto do Índio), com a regulamentação pelo Decreto 1.775/1996 e pela Portaria/MJ no 14/1996. A competência administrativa para deflagrar a demarcação é da FUNAI, a partir da qual devem ser cumpridas as seguintes etapas: a) Identificação e Delimitação, mediante estudos realizados por um grupo técnico, coordenado por antropólogo, que apresentarão relatório circunstanciado e, após a sua aprovação pela presidência da Funai, segue para a fase seguinte; b) Declaração, mediante portaria do ministro da Justiça; c) Demarcação física; d) Homologação via decreto do Presidente da República e 5) Registro em cartório imobiliário e na SPU.

Existem várias categorias normativas de terras indígenas, cada uma revela a fase de regularização fundiária criada pelo Estado. Os Kaiowá e Guaranis em MS vivem nas seguintes situações em suas terras tradicionais: a) as reservas indígenas criadas pelo antigo SPILTN e SPI entre 1915 e 1928; b) as terras indígenas regularizadas, a partir de 1984; c)

\footnotetext{
${ }^{24}$ Souza Filho (2006, p. 125-27) traça um itinerário jurídico deste instituto, cujas origens remotam a Lei de Terras (lei 601, de 18/09/1850), que dentre outros aspectos, determinava que fossem reservadas terras para a colonização dos indígenas e o Alvará de $1^{\circ}$ de abril de 1680, que garantia concessões de terras desde que "reservado o direito dos índios, primários e naturais senhores dela". Entende-se que o indigenato nunca foi revogado e paulatinamente passou a ser recepcionado por todas as constituições republicanas. Para o autor, "dentro destas terras reservadas, estavam contidas não só as que efetivamente a autoridade reservara para formar aldeamentos, como as congenitamente possuídas, isto porque o termo "reservado" se referia antes aos direitos dos índios às terras que possuíam e depois passou a designar também, nessas mutações próprias do direito e das sociedades, aquelas que o Poder Público achava melhor para aldear povos indígenas, na ideia da integração cidadã. Isto explica porque até hoje se apelidam de Reservas Indígenas".

${ }_{25}$ Tanto o Estatuto do Índio quanto a Constituição de 1988 previram o prazo de cinco anos a partir das datas das suas publicação e promulgação para a conclusão da demarcação das terras indígenas no Brasil.
} 
as terras indígenas encaminhadas, mas que têm alguma pendência administrativa ou judicial; d) aquelas terras indígenas que são objeto de reivindicação, mas não foram incluídas na lista das terras em estudo, constituindo terras sem encaminhamento administrativo por parte da FUNAI.

As terras de Sucurui'y e Jatayvary (Capítulos 4 e 5), a primeira já regularizada e a segunda com pendências administrativas e judiciais se inserem no contexto do movimento de retomada das terras indígenas. A terra indígena Sucuríy foi delimitada com uma dimensão que a coloca dentro do modelo de ilha. O próprio relatório de identificação informa da exclusão de uma parte da terra de ocupação tradicional indígena para evitar conflitos com uma outra propriedade rural:

Por fim, excluiu-se no limite sul da área um pequeno trecho à margem esquerda do córrego Taperinha, com o assentimento dos próprios Kaiowá, que aceitaram os argumentos dos técnicos da FUNAI sobre a conveniência de se tomar limites naturais na delimitação, e dos técnicos do INCRA e TERRASUL, em favor do não envolvimento de mais uma propriedade distinta das duas já incidentes no restante da área (COUTINHO JR, 1995, p. $150)$.

O relatório de identificação e delimitação de terras indígenas além de ser um instrumento técnico jurídico-administrativo que serve de base para a demarcação física está situado em um "campo de forças entre índios e regionais", resultante de uma relação complexa em que os limites são construídos. Teófilo da Silva (2005, p. 250-2) ressalta a existência de elementos políticos envolvendo os limites fixados: "na verdade, busca-se, na medida do possível, construir dialogicamente uma proposta de circunscrição territorial politicamente sustentável para índios e órgão indigenista".

Cavalcante (2013, p. 279) ressalta que nem sempre a demarcação em ilhas 'foi responsabilidade dos antropólogos coordenadores dos GT's, mas sim de uma política do governo brasileiro, por meio de seu órgão indigenista, para a questão fundiária guarani e kaiowa em Mato Grosso do Sul". Para este autor, tanto o modelo de reservas indígenas quanto o de demarcação de terras indígenas em ilhas configuram uma política que gerou uma territorialização precária (idem, p. 133).

Já as terras indígenas encaminhadas, em fase administrativa e/ou judicial, podem estar em alguma das seguintes fases: a) administrativa: identificação e delimitação, declaração, demarcação, homologação, registro; b) judicial: com ou sem perícia. Sobre as terras indígenas sem encaminhamento administrativo, mas reivindicadas pelos índios, há o caso de Laranjal que se enquadra nesta hipótese. A comunidade de Laranjal permanece acampada à beira da Rodovia BR - 060, nas proximidades do município de Jardim. O seu tekoha não foi incluído em nenhum Grupo de Trabalho para identificação e delimitação de terras indígenas. 
O movimento de reivindicação de terras resultou em um Termo ou Compromisso de Ajustamento de Conduta $^{26}$ entre Ministério Público Federal e FUNAI, em 12/11/2007, para que o órgão indigenista constituísse grupos técnicos coordenados por antropólogos com a finalidade de identificação, delimitação e demarcação de terras indígenas. Foram criados seis $\mathrm{GT}^{\prime} \mathrm{s}^{27}$, divididos por bacia hidrográfica, tomando como marco teórico a ideia de tekoha guasu. Os prazos estabelecidos no TAC, na sua maioria, não foram cumpridos, encontrando-se em diversas fases de desenvolvimento.

Cavalcante (2013, p. 291-2) sintetizou vários fatores que confluíram para a assinatura deste TAC, tais como: "a) a pressão dos Guarani e Kaiowa para que suas terras fossem devidamente reconhecidas pelo Estado; b) a atuação do MPF como defensor dos interesses indígenas; e c) a existência de vontade política alinhada entre a direção da FUNAI, o Ministério da Justiça e a própria Presidência da República".

Em síntese, a estrutura de demarcação congrega três modelos de terras indígenas guarani-kaiowá em MS: a) modelo de reserva; b) modelo de terra indígena em ilha; c) modelo de terra indígena que se pretende implementar com base no TAC/2007, ou seja, baseado no tekoha guasu e em bacias hidrográficas.

A experiência histórica das demarcações no sul de MS tem demonstrado que o tempo entre o início dos estudos de identificação e delimitação até a completa regularização fundiária das terras indígenas tem se estendido por anos a fio, em alguns casos por décadas. São inúmeros os fatores que influenciam essa dinâmica, assim como as estratégias de defesas de todos os sujeitos envolvidos.

Um dos elementos que tem retardado imensamente o prosseguimento de estudos de identificação ou das fases seguintes do procedimento demarcatório é a propositura de inúmeras ações e de recursos judiciais dos titularizados das terras de ocupação tradicional indígena, assim como dos municípios e do estado de MS. Em muitos casos, o exercício do direito de ampla defesa e do contraditório, baluartes do Estado Democrático de Direito, tem, de diversas maneiras, obstaculizado os direitos sociais indígenas. O tempo do direito e dos seus operadores tem aprofundado as crises sociais, econômicas e ambientais dos povos kaiowá-guarani.

\footnotetext{
${ }^{26}$ Instrumento previsto na lei 7.347/85 (Lei da Ação Civil Pública), no seu art. 5오 § 6ํpara a proteção de direitos difusos e coletivos, em que as partes se comprometem a cumprir as cláusulas acordadas e, no caso do seu descumprimento, terá eficácia de título executivo extrajudicial.

27 São eles, com as terras indígenas reivindicadas que abrangem: 1) Amambaipegua (Guayviry); 2) Iguatemipegua (Puelito Kue, Mbarakay, Karaguatay, Mboiveve, Jukeri, Ka'ajari, Kurusu Amba, Samakuã e Karaja Yvy (Canta Galo)); 3) Apapegua (Kandire, Jaguari, Kokue'i, Mbakaiowa, Syvyrando, Damakue, Ita, Cabeceira Comprida); 4) Dourados-Amambaipegua (Pakurity, Jukeri'y, Santiago Kue (San Lucas), Yrukuty (Barreiro Guasu), Passo Piraju); 5) Brilhantepegua (Karumbe/Yvyrarõry, Jaguaretekue, Mbykureaty, Aguara, Tatuí, Itajeguakua, Kanguery, Yasori, Rancho Pindo, Potrro Guasu, Ithaum) e 6) Ñandevapegua (Ypo'i, Garcete Kue, Mbokaja, Vito'i Kue, Laguna Piru). "Pegua" na língua guarani indica "procedência de".
} 


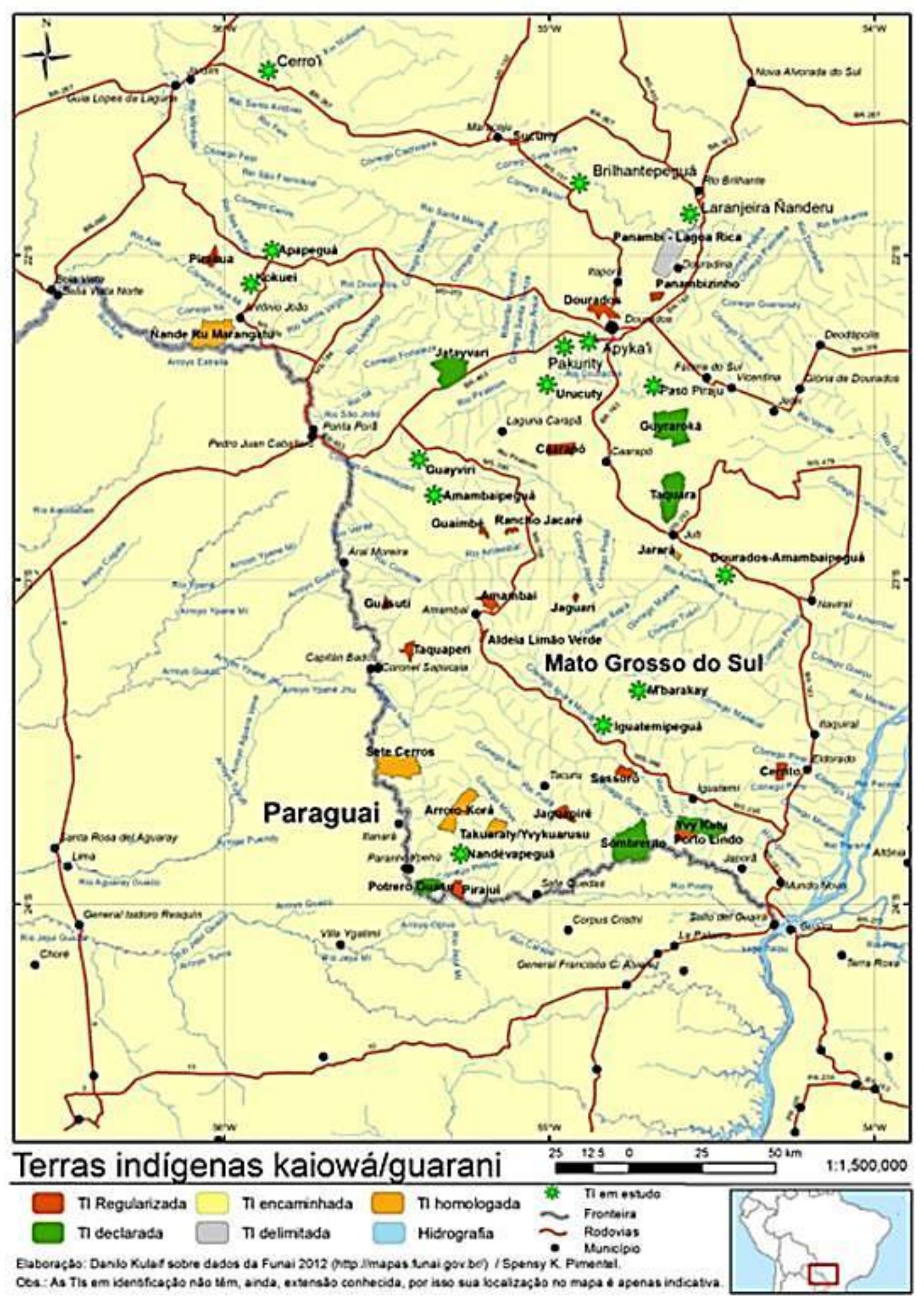

Mapa 1 - Terras indígenas Kaiowá-Guarani.

Fonte: PIMENTEL (2012, p. 5). 
Muitas das conquistas de direitos fundamentais dos povos indígenas previstas na Constituição de 1988 e nas normas internacionais ratificadas pelo Brasil, como a Convenção 169/89 da OIT $^{28}$ e a Declaração das Nações Unidas sobre os Direitos dos Povos Indígenas, de 2007 estão ameaçadas por uma série de projetos de lei e atos administrativos no cenário atual $^{29}$. Esta insegurança jurídica constitui uma afronta a diversidade social, étnica e ambiental, pois, põe em risco a própria sobrevivência física e cultural destes povos, bem como a nossa, pois, o que está em jogo é o respeito à democracia e a Constituição.

Em um recente manifesto de repúdio contra o retrocesso constitucional e os ataques à democracia e ao pluralismo, grupos de pesquisa da UnB, assim se manifestaram: "a luta pela transformação do direito não pode ser a luta pela ampliação de privilégios, ou ampliação das estruturas de dominação, mas sim a afirmação de outros modos de bem viver, de viver junto, viver na interculturalidade" (TEÓFILO DA SILVA, 2013).

\subsection{COLONIALIDADES E TRANSFORMAÇÕES AMBIENTAIS}

\subsubsection{O labirinto de colonialidades}

Velhas e novas questões se sobrepõem no mosaico de colonialidades. Velhas formas que passavam pela violência física a povos nativos e pela exploração e destruição direta da terra assumem outros refinamentos de natureza simbólica com estratégias diversificadas de dominação pelo poder e pelo saber. Por outro lado, os povos e a terra se adaptam e se recriam através de mecanismos de resiliência, de resistência e de outras formas de luta.

Quijano (2000) ao discutir as relações entre colonialidade do poder e eurocentrismo situa a América como sendo a primeira identidade da modernidade, que foi colonial desde o seu ponto de partida e, por isso, revela ambiguidades e contradições. A partir deste "encontro" entre europeus e povos nativos desenvolveram-se no decorrer dos séculos novas

\footnotetext{
28 Fajardo (2009, p. 11 e 28) entende que a Convenção 169 teve um impacto considerável sobre o constitucionalismo latino-americano, trazendo toda uma gama de reformas, que ela classifica em três ciclos: 1) de 1982-1988, com a emergência do multiculturalismo e o direito à diversidade cultural, em que se situam as Constituições da Guatemala (1985), da Nicarágua (1987) e do Brasil (1988); 2) de 1989-2005, com a ideia de Estado-Nação Multicultural e o reconhecimento do pluralismo jurídico interno, presente nas Constituições de: Colômbia (1991), México (1992), Peru (1993), Bolívia (1994, 2004), Argentina (1994), Equador (1998) e Venezuela (1999); 3) de 2006-2008, caracterizado pela demanda pelo Estado Plurinacional, representado pelas constituições de Bolívia (2007-8) e Equador (2008).

${ }^{29}$ É o caso da PEC 215/2000, que transfere a competência do Congresso Nacional para normatizar sobre demarcação de TI's; da PEC 237/2013, que permite concessão e arrendamento de TI's por produtores rurais; do PL 1610/1996, que trata de mineração em TI's e do PL 227/2012, que disciplina o processo demarcatório e trata de definir o que é bem relevante da União, abrindo margem a manter latifúndios. Além de atos como a Portaria 303/2012 da AGU que restringiu a ampliação de áreas e determinou a revisão de TI's já regularizadas com base as condicionantes do STF no julgamento do processo da TI Raposa Serra do Sol e da Portaria Interministerial 419/2011, que estabeleceu prazos ínfimos para a manifestação da FUNAI no procedimento de licenciamento ambiental.
} 
identidades (índios, negros, mestiços, brancos) que serviram para classificar socialmente a população, onde a raça é usada para legitimar as relações de dominação da conquista.

Os colonizadores tiveram muitas vantagens econômicas no capitalismo mundial face à posição geográfica da América e através do controle das riquezas naturais e do trabalho gratuito de índios, negros e mestiços. "A distribuição racista do trabalho no interior do capitalismo colonial/moderno se manteve ao largo de todo o período colonial" (QUIJANO, 2000 , p. 5). A Europa passou a exercer sua hegemonia e controle em todas as formas de subjetividade, da cultura, do conhecimento e da sua produção. "O etnocentrismo colonial e a classificação racial universal ajudam a explicar porque os europeus foram levados a sentirse não apenas superiores a todos os demais povos do mundo mas, em particular, naturalmente superiores" (QUIJANO, 2000, p. 10).

O conceito de colonialidade do poder e do conhecimento também se aplica a natureza (ESCOBAR, 2011). A visão europeia de natureza imposta pela colonização na América Latina era a de conquistar e dominar a natureza, esta vista como selvagem nos escritos de naturalistas e viajantes do século XVI. A natureza precisava ser controlada e conquistada bem como os povos indígenas civilizados.

Na construção dos "mitos fundacionais da versão eurocêntrica da modernidade" estão presentes vários dualismos como: primitivo/civilizado; irracional/racional; tradicional/moderno; mágico-mítico/científico; em síntese, não-europeu/europeu. Esta maneira de ver o mundo influenciou a formação dos diversos Estados-Nações na América Latina. As situações coloniais vivenciadas pelos Estados revelam o seu comportamento para com os povos nativos. Quijano (2000, p. 37) os classificou da seguinte forma: a) nos países do cone sul (Argentina, Chile e Uruguai) - houve uma eliminação massiva dos índios, negros e mestiços, refletida na homogeneização racial, por conta do genocídio da população original; b) no México e na Bolívia - há uma maioria índia, negra e mestiça; c) na Colômbia - a população original foi quase exterminada no período colonial e realocada com os negros; d) no México, no Peru, no Equador, na Guatemala e na Bolívia - houve uma homogeneização cultural frustrada através do genocídio cultural de índios, negros e mestiços; e) no Brasil, na Colômbia e na Venezuela - há uma ideologia da democracia racial, escondendo a discriminação e a dominação colonial.

São muitas as análises sobre colonialismos e suas variantes, uma delas é a de colonialismo interno que passou a ser desenvolvida para a interpretação de sociedades subdesenvolvidas, em especial, na América Latina a partir dos anos 1960, com os estudos pioneiros de Gunnar Myrdal, C. Wright Mills e Jacques Lambert, com o seu conceito de sociedade dual. Dois marcos importantes para esta temática foram os trabalhos realizados pelos sociólogos mexicanos Rodolfo Stavenhagen e Pablo Gonzaléz Casanova, que tratam 
o colonialismo interno como uma categoria sociológica capaz de explicar "sociedades plurais", com diversidade étnica.

Casanova (2007, p. 2-4) situa o colonialismo interno como um fenômeno econômico, político, social e cultural vinculado à conquista em que "os povos, minorias ou nações colonizadas pelo Estado-nação sofrem condições semelhantes às que os caracterizam no colonialismo e no neocolonialismo em nível internacional". Contextualmente, situa a sua argumentação nos casos históricos ocorridos com as Revoluções Russa, Chinesa e Mexicana, no início do século XX, mas os casos de colonialismo interno se manifestaram mais tarde, "ligados ao surgimento da nova esquerda dos anos sessenta e a sua crítica mais ou menos radical das contradições em que haviam incorrido os estados dirigidos pelos comunistas e pelos nacionalistas do Terceiro Mundo" (Idem).

Na América Latina, o colonialismo interno se dá no interior de uma nação, em uma relação de dominação de grupos e/ou classes dominantes para com grupos étnicos heterogêneos em que a relação de poder está dividida entre àqueles detentores do "progresso e do desenvolvimento" versus "os atrasados e primitivos". Assim, "os Estados de origem colonial e imperialista e suas classes dominantes refazem e conservam as relações coloniais com as minorias e as etnias colonizadas que se encontram no interior de suas fronteiras políticas" (CASANOVA, 2007, p. 08).

O colonialismo interno foi se transformando em estruturas mais complexas, ao ponto de distintos níveis de colonialismo se combinarem e "com o triunfo mundial do capitalismo sobre os projetos comunistas, social-democratas e de libertação nacional, a política globalizadora e neoliberal das grandes empresas e dos grandes complexos político-militares tende a uma integração da colonização inter, intra e transnacional" (CASANOVA, 2007, p. 18-9). Este debate ganhou muito fôlego na África do Sul e nos países da América Central através de novas lógicas de luta e de resistência da sociedade civil (principalmente, dos grupos marginalizados e das minorias) face ao Estado.

No Brasil, Cardoso de Oliveira (1978) a partir do seu trabalho sobre fricção interétnica, que trata da análise das sociedades tribais em situação de contato com a sociedade nacional, enfatizou a importância dos estudos de colonialismo interno na etnologia. Assim, o etnólogo pode ser orientado para analisar a sociedade como um todo e, não apenas nas suas manifestações regionais, tendo o mérito de "transformar a questão indígena (...) num sensível microscópio através do qual seriam conhecidos aspectos novos do Segundo Brasil, sua dinâmica expansionista, o sistema de poder que lhe é inerente - e de cuja primeira vítima é o Brasil indígena" (Idem, p. 81).

Tal leitura hoje em dia, soa bastante atual e permite, ao meu ver, várias aproximações com os processos de expansionismo agropecuário e mineral, que contam com o aval do Estado brasileiro e de órgãos financiadores de tais projetos, por sobre terras indígenas, 
sejam elas demarcadas, identificadas ou em fase de reivindicação. Neste sentido, conforme Mignolo (2004, p. 668):

hoje a descolonização já não é um projeto de libertação das colônias, com vista à formação de Estados-nação independentes, mas sim o processo de descolonização epistêmica e de socialização do conhecimento. A diversidade epistêmica será 0 horizonte para o qual convergem 0 'paradigma de transição' (ou um paradigma de conhecimento prudente para uma vida decente), proposto por Boaventura de Sousa Santos, e 'um outro paradigma' que está a surgir da perspectiva de conhecimentos e racionalidades subalternos.

Das críticas a projetos de desenvolvimento destinados a povos indígenas, identificados com ideais colonizadores surgiu, a partir dos anos 1980, o conceito de etnodesenvolvimento ou desenvolvimento com identidade cultural, sendo visto como uma alternativa às teorias tidas como desenvolvimentistas e etnocidas. Esta ideia também passou a fundamentar o discurso das agências multilaterais de financiamento, como o BID e BIRD na América Latina. Paralelamente a este modelo de desenvolvimento, ingressou o discurso do indigenismo participativo, devendo conduzir ao respeito à diversidade cultural e a autonomia dos povos indígenas.

Em perspectiva histórica, nos anos 1990, começou a fazer parte do ideal modernizante do desenvolvimento a ideia de capital social e empoderamento dos excluídos. Sucederamse várias experimentações em comunidades andinas para concretizar as políticas e programas desenhados pelas agências multilaterais. Portanto, muitas dessas práticas resultaram na necessidade de capacitações da comunidade indígena para gerir e executar o modelo de desenvolvimento.

A construção de um desenvolvimento diferenciado para os povos indígenas e outras comunidades tradicionais conduziu a formulação de etnodesenvolvimento por Stavenhagen (1985) como um desenvolvimento que considera suas autonomias e autodeterminações, devendo atender:

\begin{abstract}
a satisfação de necessidades básicas do maior número de pessoas ao invés de priorizar o crescimento econômico, embutindo uma visão endógena, ou seja, dar uma resposta prioritária à resolução dos problemas e necessidades locais; valorizar e utilizar conhecimento e tradição locais na busca da solução dos problemas; visando a auto-sustentação e independência de recursos técnicos e de pessoal e proceder a ação integral de base, com atividades mais participativas.
\end{abstract}

Refletindo sobre a utilização da palavra desenvolvimento, SOUZA FILHO (2009, p.35) alerta que o termo "é em si inadequado, mesmo quando adjetivado como sustentável ou étnico. Geralmente trata-se de uma ideia exógena às práticas produtivas dos índios. Por isso, o grande desafio é enxergar, aceitar e adotar o conceito indígena de economia, e não o modelo ocidentalizado". Apesar de recair sobre esta noção uma certa imprecisão, devido ao seu viés generalista, é importante perceber a possibilidade de uma interpretação de caráter 
afirmativo, no sentido de construir um modelo de desenvolvimento que leve em consideração as peculiaridades de uma dada cultura sem que haja um refinamento das formas de colonialidade.

Devido à ascensão dos debates e discursos sobre povos tradicionais e conservação ambiental, inclusive para a construção de modelos de políticas e de gestão de espaços naturais, Ulloa (2004) analisa os processos de construção de identidades ecológicas na Colômbia e descreve um fenômeno decorrente das interações das políticas cultural e ambiental dos movimentos indígenas e das políticas ambientais nacionais e globais, que chama de nativo ecológico. Neste contexto, os indígenas passam de um "sujeito colonial selvagem" a um "ator político-ecológico", ou seja, àqueles que protegem o meio ambiente e trazem esperança para a solução da crise ambiental e do desenvolvimento.

Neste sentido, Carneiro da Cunha e Almeida (2009, p. 277-9) ao refletirem sobre os fundamentos dos compromissos das populações tradicionais ${ }^{30}$ para com a conservação ambiental, questionam: "será que esse compromisso é uma fraude? (...) será que não se trata de um caso de projeção ocidental de preocupações ecológicas sobre um "bom selvagem ecológico" construído ad hoc?" Ao que chegam a um consenso: "Todos esses grupos apresentam, pelo menos em parte, uma história de baixo impacto ambiental e demonstram, no presente, interesse em manter ou em recuperar o controle sobre o território que exploram".

Os anos 1970 são um marco temporal importante, pois, há a ascensão do discurso e da institucionalização ambiental internacional, com o relatório Limites do Crescimento e a Declaração de Estocolmo para o Meio Ambiente e Desenvolvimento. Então, boa parte da construção de identidade passa pela luta política dos movimentos indígenas, pelas definições legais e antropológicas, pelos novos estereótipos nacionais e internacionais, principalmente, relacionados com ideias ecológicas.

O nativo ecológico "é produto de diversos discursos gerados por vários atores sociais situados em diferentes pontos do espectro do poder" (ULLOA, 2004, p. 10). Ele surge em um contexto de crise com sua consequente promoção de consciência ambiental, de desenvolvimento sustentável, de movimentos ambientalistas nacionais e globais e da política cultural e ambiental indígena. A autora percebeu que as concepções indígenas sobre a natureza tem influenciado o discurso ambientalista global. Na América Latina há vários exemplos de grupos indígenas que lutaram contra projetos de madeireiras, petrolíferas, hidroelétricas, estradas etc. Além disso, os indígenas têm estabelecido relações

\footnotetext{
${ }^{30}$ Concordo com a definição dos autores sobre populações tradicionais, como "grupos que conquistaram ou estão lutando para conquistar (prática e simbolicamente) uma identidade pública conservacionista que inclui algumas das seguintes características: uso de técnicas ambientais de baixo impacto, formas equitativas de organização social, presença de instituições com legitimidades para fazer cumprir suas leis, liderança local e, por fim, traços culturais que são seletivamente reafirmados e reelaborados" (CARNEIRO DA CUNHA, ALMEIDA, 2009, p. 277).
} 
com comunidades étnicas ao redor do mundo. Para tal, têm utilizado novas tecnologias de comunicação, é o que se pode chamar de uma "eco-comunidade indígena transnacional".

No entanto, há um alerta de possível ambivalência ${ }^{31}$ do nativo ecológico, pois, como destaca Ulloa (2004), o interesse ambiental pode relacionar-se com os imaginários colonialistas e nacionalistas sobre o 'nativo tradicional' que estão presentes nos projetos de desenvolvimento, como nos processos capitalistas que os introduzem nos circuitos de produção e consumo, como o turismo ecológico e étnico, a agroecologia, a bioprospecção.

Passo a descrever e discutir alguns elementos da política ambiental e indigenista ${ }^{32}$ brasileira a partir dos anos 1990, cuja reflexão sobre colonialidade e identidade ecológica indígena pode apontar alguns caminhos a serem percorridos ou evitados na busca de uma sustentabilidade que seja, minimamente, descolonizada.

No Brasil, a partir da década de 1990, impulsionados pela Conferência das Nações Unidas sobre Meio Ambiente e Desenvolvimento (ECO-92), os movimentos sociais e ambientalistas pressionaram governos e instituições no sentido de criarem normas, políticas públicas e mecanismos de financiamento para a proteção de florestas e da cultura de grupos tradicionais que habitam estes espaços. Neste contexto, destacou-se o programa piloto para a proteção das florestas tropicais do Brasil (PPG7), oriundo de um acordo feito em 1991 entre o Brasil, a União Europeia, o Banco Mundial e o G-7 (Alemanha, Reino Unido, Estados Unidos, Canadá, França, Itália e Japão).

O PPG7 desenvolveu vários projetos de sustentabilidade voltados às populações locais e à preservação das florestas tropicais. Tiveram destaque dois deles: 1) o subprograma projetos demonstrativos (PDA), iniciado em 1995, com o fito de estimular e financiar projetos sustentáveis de populações na Amazônia e Mata Atlântica; 2) o projeto integrado de proteção às populações e terras indígenas da Amazônia Legal (PPTAL), iniciado em 1996, com a finalidade de garantir a demarcação e proteção das terras indígenas localizadas na Amazônia Legal brasileira (MINISTÉRIO DA JUSTIÇA, 2011).

A experiência destes programas deu origem aos projetos demonstrativos dos povos indígenas (PDPI), iniciado em 2001, um programa do governo brasileiro cuja finalidade foi: "melhorar a qualidade de vida dos povos indígenas da Amazônia Legal brasileira, fortalecendo sua sustentabilidade econômica, social e cultural, em consonância com a

\footnotetext{
${ }^{31}$ Ambivalência destacada por FOLADORE e TAKS (2004, p. 342): "essas ambivalências estão enraizadas nas distintas práticas concernentes ao mundo material e nas posições particulares das pessoas e grupos em determinada estrutura social, assim como na dinâmica da luta ideológica, por meio da imposição de certos discursos sobre o ambiente, sua conservação e transformação".

32 Gallois (2005, p. 30) questiona a contribuição das políticas públicas para a sustentabilidade dos modos de vida indígenas, já que carregam consigo sérias contradições. "No campo indigenista, as políticas públicas estão atualmente voltadas ao atendimento de demandas emergentes, praticando-se um assistencialismo que já demonstrou e continua sendo o principal causador da ruptura na sustentabilidade dos modos de vida indígenas". Por isso, considera a sustentabilidade como uma meta e um objetivo, não uma política pública. "Se existir alguma política de sustentabilidade, ela só pode ser uma política indígena".
} 
conservação dos recursos naturais de seus territórios" (MINISTÉRIO DA JUSTIÇA, 2011). O PDPI teve duas áreas básicas de atuação: a) o apoio a projetos no nível local, envolvendo a proteção das terras indígenas, as atividades econômicas sustentáveis e o resgate e valorização culturais; b) o apoio ao fortalecimento institucional e à capacitação para gestão do movimento indígena.

Os princípios fundamentais que orientaram a atuação do PDPI foram: respeito e valoração da diversidade cultural; autonomia; inovação; caráter demonstrativo; participação; sustentabilidade e capacitação. Ao longo da sua existência mais de setenta projetos foram aprovados e o programa foi se aperfeiçoando. Destacaram-se também o projeto de proteção etnoambiental de povos indígenas isolados na Amazônia brasileira e as frentes de proteção etnoambientais, que também atuaram na Amazônia.

Outro projeto do governo federal na área de gestão ambiental e territorial de terras indígenas foi o "Catalisando a Contribuição das Terras Indígenas para a Conservação dos Ecossistemas Florestais Brasileiros", conhecido como GEF Indígena, fruto do grupo de trabalho interministerial (Portaria 325/04). Este, servindo de apoio à política nacional de gestão territorial e ambiental de terras indígenas, aprovado pelo fundo global para o meio ambiente (GEF) da Organização das Nações Unidas (ONU), em agosto de 2009. Tal projeto teve o papel de: "fortalecer e proporcionar meios de realizar os objetivos da PNGATI, ao reconhecer a importância das terras indígenas para a conservação da biodiversidade, e a necessidade de implantar ações que apoiem os povos indígenas na sua busca pela gestão e manejo sustentável dos recursos naturais destas terras" (PNGATI, 2009, p. 06).

A formulação da Política Nacional de Gestão Ambiental e Territorial em Terras Indígenas (PNGATI) como uma política pública para a gestão das terras indígenas sinalizou, segundo Oliveira (2011, p. 9), uma tendência que vem sendo demonstrada nos últimos vinte e cinco anos pelo Estado brasileiro de propiciar uma participação dos povos indígenas nas questões dos seus interesses e também de: "indicar a configuração de uma 'fase pósdemarcatória' de terras indígenas". Fase esta, bem distante da realidade apresentada no sul de MS para os guarani-kaiowá.

O marco temporal da construção da PNGATI firmado pelo estado brasileiro e seus parceiros $^{33}$ compreende o período de setembro de 2008 a junho de 2010 . O trabalho de coordenação coube ao Ministério da Justiça, por via da FUNAI, do Ministério do Meio

\footnotetext{
${ }^{33}$ As instituições parceiras foram: The Nature Conservancy (TNC); Instituto Socioambiental (ISA); Instituto Internacional de Educação do Brasil (IEB); Conservação Internacional (Cl); Deutsche Gesellschaft für Internationale Zusammenarbeit (GIZ); Cooperação Alemã para o Desenvolvimento (GmbH); Programa das Nações Unidas para o Desenvolvimento (PNUD) e Fundo Global para o Meio Ambiente (GEF) (OLIVEIRA, 2011, p. 8).
} 
Ambiente (MMA) e da Articulação dos Povos Indígenas do Brasil ${ }^{34}$ (APIB) conforme as Portarias Interministeriais 276, de 12/09/08 e 434, de 09/12/09. A composição paritária do Grupo de Trabalho Interministerial (GTI) foi formada por seis representantes do governo e mais outros seis indígenas ${ }^{35}$, além de membros do Ministério da Defesa e do Serviço Florestal Brasileiro como convidados permanentes.

A primeira etapa dos trabalhos consistiu na elaboração de um documento base chamado de "Documento de apoio para as Consultas Regionais" que subsidiou a etapa seguinte, referente às cinco "Consultas Regionais aos povos e organizações indígenas" sobre o conteúdo da PNGATI (OLIVEIRA, 2011, p. 8). O documento de apoio para as consultas regionais no âmbito do PNGATI estabeleceu como objetivo geral a promoção da proteção, da recuperação, da conservação e do uso sustentável dos recursos naturais dos territórios indígenas. Os seus objetivos específicos, foram: a remuneração dos serviços ambientais; a recuperação de áreas degradadas; a recuperação e conservação da agrobiodiversidade; o etnozoneamento e a faixa de segurança etnoambiental no entorno das terras indígenas.

O processo de construção teve como base: a participação dos povos indígenas e o envolvimento de suas organizações; a fundamentação da discussão sobre os objetivos e as diretrizes da PNGATI em propostas discutidas e construídas com participação dos povos e organizações indígenas e a incorporação do acúmulo de discussões e experiências consolidadas no âmbito de políticas, programas, ações, projetos e eventos da área de gestão ambiental e territorial de terras indígenas (PNGATI, 2009, p. 01). Foram realizadas cinco consultas regionais ${ }^{36}$.

\footnotetext{
${ }^{34}$ A APIB foi criada no Acampamento Terra Livre de 2005 e congrega as seguintes organizações indígenas regionais: Articulação dos Povos Indígenas da Região Sul (Arpinsul); Articulação dos Povos Indígenas do Pantanal e Região (Arpipan); Coordenação das Organizações Indígenas da Amazônia Brasileira (COIAB); Articulação dos Povos Indígenas da Região Sudeste (Arpinsudeste); Aty Guassu (Grande Assembleia Guarani) e Articulação dos Povos Indígenas do Nordeste, Minas Gerais e Espírito Santo (Apoinme) (OLIVEIRA, 2011, p. 16).

${ }^{35}$ O quadro ficou da seguinte forma: três representantes da Funai, sendo um da Diretoria de Assuntos Fundiários, atual DPT e dois da Diretoria de Assistência, atual DPDS; três representantes do MMA, provenientes cada um da Secretaria de Extrativismo e Desenvolvimento Rural Sustentável, da Secretaria de Biodiversidade e Florestas e do IBAMA. Já a composição indígena ficou distribuída entre representantes das diversas regiões do país, sendo: dois do Norte e um para cada outra região (OLIVEIRA, 2011, p. 20-1).

${ }^{36}$ As consultas regionais foram realizadas, respectivamente, em Recife (23 a 26/11/2009), Curitiba (14 a 17/12/2009), Campo Grande (26 a 29/1/2010), Cuiabá (27 a 30/5/2010) e Manaus (25 a 28/6/2010). A proposta era colher sugestões para aperfeiçoar o texto do GTI da PNGATI. A metodologia de trabalho, o tempo de duração (quatro dias, incluindo a chegada e a partida), a participação dos representantes foi definida pelo GTI, mas no decorrer do processo foram feitas adaptações e modificações mais significativas como à consulta prévia para a regional de Cuiabá e de Manaus. A primeira consulta regional, no Recife, teve o apoio da Apoinme, contou com aproximadamente 240 indígenas representativos de 47 povos da região nordeste, de Minas Gerais e do Espírito Santo. A segunda, em Curitiba, foi apoiada pela Arpinsul, teve a participação de 140 indígenas vindos de 12 povos dos estados do sul e de São Paulo e do Rio de Janeiro. A terceira consulta, em Campo Grande, com apoio da Arpinpan, Aty Guassu e ACIRK (Associação da Comunidade Indígena da Reserva Kadiwéu) com cerca de 190 indígenas de 7 povos distintos. Essas três consultas ocorreram com pequenas adaptações face à proposta metodológica do GTI (OLIVEIRA, 2011, p. 29-37). Contudo, para as duas últimas consultas regionais ocorreram mudanças mais significativas através das chamadas "reuniões prévias" para melhorar o entendimento da proposta da PNGATI e facilitar um consenso entre as organizações indígenas. A quarta consulta regional
} 
A política definiu a gestão territorial e ambiental de terras indígenas como sendo o "conjunto de domínio político e simbólico do espaço que constitui o território de um povo indígena, englobando os seus saberes tradicionais e suas práticas quanto ao uso dos recursos naturais e da biodiversidade". Envolveu, ainda, "a dimensão dos mecanismos, dos processos e das instâncias culturais de decisão relacionados aos acordos de uso e os consensos internos próprios de cada povo, e que são necessários para a busca da sustentabilidade ambiental das terras indígenas" (PNGATI, 2009, p. 09).

Segundo publicação oficial, "a principal marca do processo de construção da PNGATI foi a "participação indígena" que ocorreu de dois modos: "i) com a inserção de seis lideranças indígenas na composição do GTI responsável pela formulação da proposta da PNGATI; e ii) com a participação de representantes e lideranças indígenas nas Consultas Regionais aos povos indígenas" (OLIVEIRA, 2011, p. 8). No entanto, questões como acesso prévio ao texto, tempo de conhecimento e de discussão do texto, maior participação indígena (e não só de lideranças), linguagem e tradução cultural, maior articulação entre os órgãos governamentais foram identificadas como pontos de entrave na construção da política (OLIVEIRA, 2011, p. 49).

Questões pendentes de regulamentações e práticas no Brasil foram confrontadas no processo de construção da PNGATI como o exercício do direito de consulta livre, prévia e informada (prevista no art. 6º da Convenção 169 da OIT), a autonomia e o protagonismo indígena e a metodologia dos diversos níveis de participação. Isso tudo aliado ao "papel ambiental" a ser desempenhado pelos povos indígenas como condutores da gestão de territórios portadores de rica biodiversidade planetária.

Apesar da última consulta regional ter ocorrido em junho de 2010, o decreto instituidor da PNGATI só foi aprovado dois anos depois, em 5 de junho de 2012, pela presidência da república. O Decreto 7.747, formado por 15 artigos, estabeleceu objetivos geral e específicos, estes estruturados em sete eixos; ferramentas; diretrizes e os órgãos da governança da PNGATI.

Observa-se que no decorrer do texto normativo houve a incorporação massiva das expressões "ambiental" e "sustentável", seguida de um vocabulário repleto de expressões como etnomapeamento, etnozoneamento, serviços ambientais, governança, educação ambiental, dente outras. Além desse aspecto, procurou-se uma compatibilização entre os modernos instrumentos de gestão territorial e ambiental com os já consagrados, porém não cumpridos, direitos à autonomia, a participação e a consulta.

ocorreu em Cuiabá e teve aproximadamente 320 indígenas representantes de 56 povos do centro oeste, Tocantins, Maranhão e Pará. Na quinta consulta, em Manaus, estiveram presentes cerca de 350 indígenas provenientes de 64 povos da região norte. 
O decreto fixou como objetivo geral da PNGATI: garantir e promover a proteção, a recuperação, a conservação e o uso sustentável dos recursos naturais das terras e territórios indígenas, assegurando a integridade do patrimônio indígena, a melhoria da qualidade de vida e as condições plenas de reprodução física e cultural das atuais e futuras gerações dos povos indígenas, respeitando sua autonomia sociocultural, nos termos da legislação vigente (art. 1ํ).

As ferramentas para a gestão territorial e ambiental são o etnomapeamento e o etnozoneamento (art. $2^{\circ}$ ), instrumentos a serem utilizados na consecução dos objetivos específicos estruturados em sete eixos. São eles: proteção territorial e dos recursos naturais; governança e participação indígena; áreas protegidas, unidades de conservação e terras indígenas; prevenção e recuperação de danos ambientais; uso sustentável de recursos naturais e iniciativas produtivas indígenas; propriedade intelectual e patrimônio genético; capacitação, formação, intercâmbio e educação ambiental.

$\mathrm{O}$ indigenismo e a proteção ambiental revelam elementos bastante complexos. As terras indígenas no Brasil são consideradas como áreas protegidas ou espaços territoriais especialmente protegidos, utilizando a linguagem constitucional (art. 225 da CF/88). Essas terras fazem parte do Plano Nacional de Áreas Protegidas (PNAP).

"Garantir, promover, contribuir, apoiar, assegurar, elaborar, implantar e capacitar" são os verbos mais recorrentes previstos no texto normativo da PNGATI, além de "reconhecimento, valorização, respeito, proteção e fortalecimento". O que demonstra um discurso bastante propositivo e, não vinculativo de deveres por parte do próprio Estado. A governança e as disposições orçamentárias também carecem de uma série de atos e compromissos que os fortaleçam para fazer com que a implementação da política ocorra.

A PNGATI enquanto política pública traz uma série de desafios à gestão das terras indígenas e a capacidade institucional dos órgãos de estado, em particular à FUNAI, nas suas atuações administrativas. Embora a fase "pós-demarcatória" exista para boa parte dos povos indígenas no Brasil, as demandas reivindicatórias por terras tradicionais persistem e reclamam uma solução histórica.

Diversas situações fundiárias fora do circuito amazônico foram historicamente negligenciadas na ordem de prioridade no processo demarcatório pelo órgão federal competente. Há duas situações bem diferentes vivenciadas pelos povos indígenas quanto à territorialidade: a) terras extensas e contínuas e b) terras descontínuas e, geralmente, minúsculas. Uma das principais dificuldades enfrentadas pelas comunidades indígenas guarani-kaiowá de Mato Grosso do Sul reside nos atrasos de regularização fundiária das terras reivindicadas, que provavelmente as receberão em um estado de grande degradação ambiental, uma vez que as de frentes desenvolvimentistas continuam a ocupar as terras tradicionais indígenas. 


\subsubsection{Itinerários da destruição}

A região sul de Mato Grosso do Sul encontra-se numa faixa de transição entre os biomas mata atlântica, cerrado e pantanal. Esta complexa teia de biodiversidade tem sido alvo de um intenso processo de utilização do solo pela pecuária e por diversas culturas agricultáveis em larga escala, como o milho, a soja e, mais recentemente, a cana-de-açúcar. Estes processos têm resultado, principalmente a partir da década de sessenta do século passado, em uma grande perda da cobertura vegetal original. Mas o sul de Mato Grosso, em meados do século XIX, conforme narração de um advogado do Estado era dotado de um:

solo virgem e feroz; as águas opulentas; as florestas riquíssimas; o clima salubérrimo. Tudo isso tentava a cobiça dos homens. A terra era de ninguém; tocaria ao primeiro ocupante. No deserto, os limites da propriedade podiam abranger $o$ infinito. Chegando a uma eminência, 0 sertanista audaz fazia uma parada, e olhando o horizonte sem fim, bradava: 'tudo isto é meu, tudo que meus olhos veem por aquela serra afora, até topar com a nascente deste rio'. Era assim que se fundavam as posses; era assim que, naquelas remotas eras se lançavam os fundamentos da propriedade (REZENDE, 1924 apud COUTINHO JR, 1995).

Desde o início da colonização da região, passando pela vinda da Companhia Matte Larangeira (1882-1943), pela CAND (1943) até o avanço das fazendas e empresas agropecuárias (século $\mathrm{XX}$ e XXI) tem havido um contínuo processo de degradação ambiental dos territórios tradicionais indígenas no sul de Mato Grosso do Sul. Situação que tem resultado na transformação das paisagens, no desmatamento, na diminuição de espécies da fauna, no assoreamento e poluição de corpos d'água e na contaminação dos solos, dentre outras consequências ambientais danosas.

Existem variações nos processos de derrubadas das matas entre as cidades do cone sul de MS em decorrência da instalação das frentes econômicas. Todavia, o ciclo de destruição das matas e dos tekohas seguiu um percurso de derrubadas da floresta e implantação das fazendas de gado e de monoculturas de soja/trigo (1960-1970) e de canade-açúcar (1980). Nas análises de Brand (2001, p. 126) cada microrregião do cone sul de MS passou por fases distintas de desmatamento entre o período crucial das décadas de 50 e 70 do século passado. Para o autor:

A data da destruição de parte das aldeias está relacionada diretamente ao avanço das derrubadas e correspondente implantação das fazendas. A destruição de parte das aldeias foi anterior à década de 1950. Estão nessa situação aquelas localizadas na área abrangida pela Colônia Agrícola Nacional de Dourados. Porém, a maior parte das aldeias teve sua destruição concluída durante as décadas de 1950 e 1960. Significativa parcela das aldeias localizadas em Caarapó e Juti, na região de Amambai/Tacuru/lguatemi, foi "esparramada" durante esse período. No entanto, outra parcela de aldeias, em especial as áreas guarani como Sombrerito, Ypo'i/Triunfo, Potrero Guasu e outras, foram destruídas no início da década de 1970. O mesmo aconteceu com as aldeias da região de 
Jaguapiré, campanário e algumas próximas a Amambai e Caarapó, tais como Samakuã, Ouro Verde, São Pedro, Km 20, Javorái/lbikui/Campo Seco e Lima Campo, onde o desmatamento ocorreu em período mais recente.

A partir dos anos 1960 passaram a ocorrer profundas modificações nas terras de ocupação tradicional kaiowá-guarani, devido ao modelo de exploração econômica e as profundas alterações ambientais, ao que Brand (1993, p.126) chamou de "desmatamento geral". A mão-de-obra indígena foi utilizada para os trabalhos de desmatamento:

Passado o auge das atividades de derrubada da mata que se estendeu pelas décadas de 1960-1970, a mão-de-obra indígena foi canalizada para a roçada dos pastos e para o plantio de pastagens exóticas. $E$, finalmente, durante a década de 1980, passou a ser a mão-de-obra preferida para os trabalhos de plantio e colheita da cana nas usinas de álcool (BRAND, 1997, p. 90).

De acordo com Moreira da Silva (2002, p. 49), na relação entre a expansão agropecuária e a utilização da mão-de-obra indígena aconteceu o:

\begin{abstract}
desmatamento intenso para criação de gado ou o cultivo de lavouras, geralmente no sistema de monocultura. O tempo de permanência dos índios na terra será apenas o suficiente ao desmatamento e estruturação das fazendas. Depois, a expulsão era inevitável. Contudo, os fazendeiros não promoviam a saída imediata dos índios. Utilizavam a mão-de-obra a preço vil na derrubada das matas, no roçado e na implantação das pastagens. Concluído o serviço, os índios eram convidados a sair. Se não surtisse efeito, ocorreria a expulsão violenta.
\end{abstract}

Na década de 1970, com a introdução massiva da soja houve uma alta mecanização pelo viés de uma agricultura "moderna". Fazendeiros vindos, principalmente do Rio Grande do Sul, mas também do Paraná, São Paulo e Minas Gerais, passaram a adquirir e arrendar terras na região de solos ricos e com abundância de água, mediante forte estímulo do poder público. Houve um aprofundamento da concentração fundiária. Este panorama causou o aumento da precificação do valor da terra e gerou forte especulação imobiliária no campo e nas cidades que, por sua vez, passaram por um amplo crescimento populacional.

Além disso, "na década de 1970, a Funai, com o objetivo manifesto de tornar as áreas indígenas produtivas e autônomas financeiramente, implanta, projetos agrícolas, baseados na mecanização" (BRAND, 1993, p. 177). Sobre os projetos de venda de madeira, Brand (1993, p. 179-80) identificou dois argumentos para o desmatamento nas reservas kaiowá: "a falta de recursos para projetos na agricultura (manutenção de máquinas) e a existência de madeira desvitalizada". Ele aponta que as madeireiras investiram "na divisão da comunidade, através da bebida e outras "benesses", e acabam retirando ilegalmente quantias superiores às que constam nos contratos".

Nos anos 1980 teve início a expansão da plantação de cana-de-açúcar no sul de MS, que além causar impactos ambientais de diversos níveis, gerou uma série de problemas as populações guarani-kaiowá através da ampla utilização da sua mão-de-obra e sobre sua organização social, saúde e relações de trabalho. 
Esta história tem o seu desenrolar a partir da construção da política brasileira para o incentivo à produção de álcool a partir dos anos 1970 com a criação de um programa econômico chamado Proálcool ${ }^{37}$ em um contexto de crise da produção de petróleo e alta nos preços em nível internacional. Com o restabelecimento do mercado do combustível fóssil, na década de 1990, o programa foi desincentivado. O movimento de apoio político e econômico ao chamado "setor sucroalcooleiro no Brasil" tem oscilado enormemente nas últimas décadas, revelando, assim, o forte papel de intervenção do Estado, cujo financiamento vem, principalmente do BNDES e de outras instituições financeiras que promovem o "desenvolvimento".

Historicamente, o setor se instalou no litoral nordestino modificando drasticamente paisagens naturais, causando a destruição da mata atlântica ${ }^{38}$ e, alterando a relação do homem com a terra. A partir da década de 1990, houve uma marcante transformação do setor, inclusive, geopoliticamente, em que as usinas sucroalcooleiras do nordeste entraram em crise, devido aos altos custos de uma mecanização em uma topografia de morros e ao endividamento, levando o capital e muitos empreendimentos para o centro-sul.

Nos anos 2000 e nos que se seguem, o setor teve um forte impulso pela introdução dos veículos bicombustíveis e com a presença marcante da ideologia de que o, agora, "etanol" é um combustível limpo e sustentável e que o Brasil figuraria como um dos maiores produtores e promotores de tecnologias inovadoras e renováveis. Umas das características da onda expansionista para o centro-sul do país é a maior concentração de grupos econômicos que atuam no setor e a forte participação de grupos com capital estrangeiro, que compram e arrendam terras para a produção de cana-de-açúcar.

O plantio de cana-de-açúcar ampliou a ocupação de espaços que antes eram utilizados para outras culturas monoculturais, como trigo, milho e soja e, ampliou o rastro da sua presença em novas áreas, provocando um aumento do valor da terra rural e inviabilizando outros usos e plantios ${ }^{39}$, o que leva a crer em desarticulações de terras de médios e pequenos agricultores, bem como da agricultura familiar. Também é emblemático o histórico de desrespeito aos direitos dos trabalhadores rurais da cana-de-açúcar, que vão

\footnotetext{
${ }^{37}$ Criado pelo Decreto 76.593/75, "o programa promoveu inicialmente o aumento do percentual de álcool anidro, produzido a partir da cana-de-açúcar, adicionado à gasolina. Posteriormente, em sua segunda fase (Decreto no. 80.762/79), promoveu a utilização do álcool hidratado em veículos com motores desenvolvidos especificamente para este combustível. Em 1985, 85\% dos automóveis vendidos no país eram movidos à álcool" (FIAN INTERNACIONAL, 2008, p. 23).

${ }^{38}$ Sobre a história da destruição da Mata Atlântica brasileira, vide o pioneiro livro sobre história ambiental no Brasil de Warren Dean (1996): A ferro e a fogo.

${ }^{39}$ A FIAN INTERNACIONAL (2008, p. 30), comparou a relação da produção da cana-de-açúcar e da soja em relação a de feijão, arroz e mandioca e verificou que entre 1990/91, os primeiros se expandiram 14,1 milhões de hectares no Brasil, enquanto que os alimentos do segundo grupo tiveram uma redução de 3,1 milhões de hectares, "com relativa estagnação do volume produzido ou ganhos decorrentes apenas do aumento da produtividade (ou seja, intensificação do uso dos solos e maior custo para o produtor)."
} 
do trabalho escravo a outras relações de exploração como baixos salários, condições inseguras e insalubres de trabalho.

No MS, o avanço do setor sucroalcooleiro (plantio e usinas) assume contornos dramáticos, pois, além de ter ampliado a pegada de destruição das monoculturas que antecederam a cana-de-açúcar e, ainda, subsistem concomitantemente, há um profundo impacto na vida de trabalhadores indígenas e na organização social das suas famílias e de tekohas. Conforme analisado no Capítulo 5, sobre a terra indígena Jatayvary, os efeitos são devastadores e continuam a produzir consequências sobre os povos guarani-kaiowá, dentro e fora das suas terras tradicionais. São muitas as pressões socioambientais, cuja lista de impactos negativos direcionam-se a produção de poluições que atingem o solo, o ar e as águas. Também é sabido e sentido pelas populações o uso intensivo de agrotóxicos que contaminam estes três elementos. Além disso, o consumo de água é imenso, cuja exploração provém na sua maioria do Aquífero Guarani.

Respeitadas as diferenças histórias, geográficas e culturais, existem características comuns que estão presentes no modelo nordestino e no modelo do centro-sul referentes ao plantio e industrialização da cana-de-açúcar: latifúndio; concentração fundiária; ampliação das desigualdades sociais; relações trabalhistas que afrontam as normas de proteção social e fortes impactos sobre o meio-ambiente, mesmo com toda a onda de "modernização e mecanização" do setor das últimas décadas.

As características marcantes de cada fase econômica, pontuadas acima, sobre o sul de MS, em relação às transformações ambientais e culturais dos kaiowá-guarani não devem ser entendidas como ciclos estanques que marcaram cada década e, sim, como dinâmicas que possuem várias interações no tempo e no espaço. O MS possui uma forte dependência econômica dos recursos naturais e um modelo de exploração a curto prazo, situação verificada também na maior parte do país. As relações econômicas e sociais se tornaram mais complexas com o decorrer do tempo e dos processos de colonização.

Atualmente, muitos dos projetos, obras, atividades e empreendimentos nos setores agropecuários, industriais e de infraestrutura se revestem de um ideal modernizante e de um discurso universalista e hegemônico de sustentabilidade para angariar parceiros financeiros e políticos na obtenção de recursos e de liberação das licenças e de outros trâmites burocráticos para o seu funcionamento.

O mesmo Estado que cria mecanismos jurídicos e administrativos para proteger os direitos territoriais e ambientais das populações indígenas é aquele que libera e financia a iniciativa pública e/ou privada para exercer projetos, obras, atividades e empreendimentos que tem/terão impactos diversos sobre o meio socioambiental de populações tradicionais. Este comportamento dúbio do estado brasileiro revela uma atuação vacilante sobre os rumos do desenvolvimento em um Estado Democrático de Direito, levando em consideração 
o conjunto de normas nacionais e internacionais sobre direitos indígenas e ambientais que contempla a diferença, a autodeterminação e o pluralismo destas sociedades.

As terras indígenas no Mato Grosso do Sul, regularizadas ou não, têm sofrido impactos ambientais, sociais e econômicos com o modelo do agronegócio ${ }^{40}$ adotado na região, o que tem provocado alterações no modo de ser e estar na terra em gerações de guarani-kaiowá. $O$ efeito das graves transformações ecológicas tem causado consequências culturais significativas que podem ser sentidas nas cerimônias, na moradia, na religiosidade, na alimentação e nos seus rituais. Esta percepção pode ser vislumbrada no discurso de xamãs, de lideranças e de movimentos como o Aty Guasu. Fato este, apontado por Pimentel (2012, p. 217) ao afirmar:

o discurso profético sobre a recuperação das terras tradicionais adquire feições ecológicas, fala frequentemente das consequências desastrosas das alterações ambientais geradas pela ação dos karail $^{41}$, por um lado, ao mesmo tempo em que exalta a recuperação do meio ambiente - e dos poderes e forças relacionadas aos xamãs, consequentemente - que advirá com a recuperação dos tekoha.

Refletindo sobre história ambiental Drummond (2002, p. 27) aponta que "nenhuma outra questão contribuiu mais para a "identidade ambiental" internacional do Brasil como o "desmatamento". Seguindo uma reflexão sobre a perda da mata atlântica, Dean (1996, p. 23-4) discorre que:

A história florestal corretamente entendida é, em todo o planeta, uma história de exploração e destruição. O homem reduz o mundo natural a "paisagem" - entornos domesticados, aparados e moldados para se adequarem a algum uso prático ou à estética convencional - ou também, o que é ainda mais assustador, a "espaço" - planícies desertas aplainadas a rolo compressor e sobre as quais o extremo do narcisismo da espécie se consagra em edificações.

Os primórdios de uma disciplina, chamada de história ambiental começou nos anos de 1970. Para um dos seus precursores, Donald Worster (1991, p. 199), ela "rejeita a premissa convencional de que a experiência humana se desenvolveu sem restrições naturais, de que os humanos são uma espécie distinta e "supernatural", de que as consequências ecológicas dos seus feitos passados podem ser ignoradas". Seu objetivo seria: "aprofundar o nosso entendimento de como os seres humanos foram, através dos tempos, afetados pelo seu ambiente natural e, inversamente, como eles afetaram esse ambiente e com que resultados" (idem, p. 200-1).

\footnotetext{
40 Segundo SCHNEIDER (2010, p. 108): "o agronegócio é entendido tanto como o conjunto de práticas tecnologicamente modernas de organização, gestão e integração comercial, geralmente capitaneadas por empresas e organizações privadas, como as formas de propriedade fundiária de grandes extensões (que outrora eram chamados de "latifúndios"), as empresas fornecedores de insumos e sementes etc.; enfim, tudo o que de um modo ou outro está associado à produção capitalista de mercadorias na agropecuária".

${ }^{41}$ É como os guarani-kaiowá chamam o homem branco.
} 
Portanto, o que se pretende neste tópico é refletir sobre alguns aspectos que dialogam com a história e sociologia ambiental, apontando elementos para aprofundamento em futuras pesquisas. Apesar de muitos estudos se encaminharem para análises da destruição ${ }^{42}$, procuro apontar elementos que sejam mais "construtivos e criadores, especialmente no que se refere aos vínculos culturais", como aponta Pádua (2012, p. 36).

Muitas abordagens na sociologia indicam que os problemas ambientais, assim como os sociais, são fruto da construção social ${ }^{43}$ que se faz deles, contudo, os primeiros, "têm uma base física mais contundente" (HANNIGAN, 2009, p. 99). Neste caso, o construcionismo é uma ferramenta analítica para se estudar os problemas ambientais, que partem de três premissas: os próprios argumentos, os argumentadores e o processo de argumentação através das seguintes tarefas: juntar, apresentar e contestar os argumentos.

Hannigan (2009, p. 117-9) sintetiza que os fatores necessários para a construção bem-sucedida de um problema ambiental, são: autoridade científica para validação dos argumentos; existência dos "popularizadores" que podem combinar ambientalismo e ciência; atenção da mídia, na qual o problema é "estruturado" como novo e importante; dramatização do problema em termos simbólicos para uma ação positiva e recrutamento de um patrocinador institucional que possa garantir legitimidade e continuidade do problema.

De certa forma, temas como aquecimento global, mudanças climáticas, perda de biodiversidade e desmatamento seguiram o percurso acima descrito. Os problemas ambientais além de serem problemas socialmente construídos, constituem questões ecológicas que devem ser analisadas para além da dicotomia natureza-sociedade.

Para Todorov (2010, p. 359), "nada é mais aflitivo do que ver a história se repetindo ainda mais no caso da história de uma destruição". De um modo geral, as terras das áreas rurais do sul de MS estão muito degradadas. Os ciclos dos processos de colonização da terra com suas frentes econômicas deixaram e seguem deixando o seu legado para às presentes e futuras gerações.

Com base nas minhas observações e nas imagens e falas do trabalho de campo, passo a refletir mais sistematicamente sobre alguns elementos comuns verificados nas três terras indígenas que compõem o estudo de caso. As regularidades analisadas referem-se ao processo de destruição das matas (ou perda do mato, como chamam muitos dos meus interlocutores) com as consequências de: enfraquecimento do solo; presença de gramíneas exóticas, como braquiária e colonião; queimadas; presença de monoculturas e destino do

\footnotetext{
42 Conforme revelado na obra de Pádua (2002, p. 10) existiu "uma reflexão profunda e consistente sobre o problema da destruição do ambiente natural por parte de pensadores que atuaram no país entre 1786 e 1888 , muito antes do que convencionalmente se imagina como sendo o momento de origem desse tipo de debate".

${ }^{43}$ Berger e Luckmann (2013, p. 15) situam a construção social da realidade como um estudo da sociologia do conhecimento, em que "o problema geral tem sido estabelecer a extensão em que o pensamento reflete os fatores determinantes propostos ou é independente deles".
} 
lixo gerado nas terras indígenas. Questões mais específicas estão descritas e analisadas nos capítulos: 3, sobre Te'ýikue; 4, sobre Sucurui'y e no 5, sobre Jatayvary.

Muitos nomes de lugares nas terras indígenas referem-se a aspectos que compõem o meio ambiente natural, biológico e geográfico, como rios, córregos, árvores e animais. Mas, muitos destes lugares estão descaracterizados ou os elementos da natureza não mais existem. A liderança de Téýikue, por exemplo, mora na região de Perobal, mas para ele: "só ficou a memória do nome Perobal, não tem mais peroba por lá. Essa região é mais cerrado. Tinha um pouco de guavira mas também acabou".

Outra questão diz respeito ao acesso a plantas utilizadas para fazer remédio, rezas e rituais. Foi uma constante na fala dos rezadores(as) das três terras pesquisadas que eles possuem o conhecimento sobre as plantas, mas o acesso a elas está escasso, difícil ou inexistente porque o mato acabou. Para conseguir as plantas que necessitam, utilizam várias estratégias, como a obtenção em outras terras indígenas, através de parentes; em fazendas dos arredores; na mata ciliar (APP) e nas reservas legais de fazendas. Às vezes falta um remédio de brejo; outras de campo/cerrado; outras de mata, tudo depende das condições ambientais de onde vivem.

Por isso, entendo que é necessário criar instrumentos jurídicos que garantam o livre acesso a áreas de mata que estejam fora de áreas demarcadas como terra indígena. Assim, diante das adversidades ecológicas, se estaria assegurando acesso a sementes e plantas nativas consideradas tradicionais para o exercício da cura e de rituais. Iniciativas como estas ocorrem no Brasil, como é o caso da chamada lei do babaçu livre no estado do Maranhão, em que as quebradeiras podem ter livre acesso as sementes onde quer que elas se encontrem, geralmente em propriedades rurais particulares. No processo de recuperação ambiental de Te ýikue (capítulo 3) muitas das sementes para o replantio de árvores foram retiradas de fazendas onde existiam remanescentes de espécies nativas.

Além das terras indígenas que foram demarcadas no modelo de ilhas (como visto no 1.1.2), as árvores e seus microecossistemas também estão ilhados. Espécies estão isoladas e sofrem cada vez mais pela não renovação, devido a não comunicação com outras espécies, e pelo efeito-borda que vai corroendo os limites que foram impostos pelo modelo econômico da região.

Em todas as terras pesquisadas, a presença da braquiária e do colonião faz parte da paisagem. Segundo Mura (2005, p. 66): “a introdução de pastagens africanas para a criação de gado extensiva, por outro lado, passou a representar uma das maiores pragas para os índios, já que seus conhecimentos técnicos se mostraram inadequados para combatê-las". Perguntei a todos os meus interlocutores, principalmente, aos rezadores e aos mais idosos: como estas espécies chegaram e se espalharam pela terra? Qual o modo de combatê-las? $\mathrm{E}$, se: existe reza para acabar com elas? As respostas e soluções foram as mais diversas. 
A idosa de Te'ýikue disse que quando a família dela chegou à região havia muito mato na fazenda. Como ela mora bem na divisa, esclareceu que, antigamente, ao lado da sua casa havia uma fazenda de gado chamada Novilho. Ela acha que a braquiária veio de lá para Te'ýikue pelo vento. Agora, onde ela mora com a família tem pouca braquiária, porque há mais árvores que se recuperaram e foram plantadas por ela e pelas netas que levaram mudas da escola. E como fazer para acabar a braquiária? Ela respondeu que: "quando as árvores crescem a raiz judia da braquiária e morre tudo. Assim que acaba".

Para o servidor 1 do viveiro de mudas em Te'ýikue, perguntei como acabou a braquiária atrás da escola. Ele disse que: "a sombra mata. Plantando árvore, aí acabou. Aqui tem muito braquiária. Aí gradeamo assim. Aí acabou a braquiária". A própria floresta acabou a braquiária. Situação confirmada pelo servidor 2: "a mata acaba. E cuidando pra não entrar fogo".

No meio da braquiária tem muitas árvores e plantas. Há muita vida que brota. Quando se põe fogo na braquiária, ela não morre, pois, tem raízes profundas, então sempre rebrota. Mas muitas mudas nativas que estão encobertas, por serem mais frágeis, acabam morrendo. Em todas as terras, nos lugares em que fiz caminhadas, foi possível verificar brotos e mudas de árvores e plantas, muitos considerados medicinais, por debaixo da braquiária e do colonião.

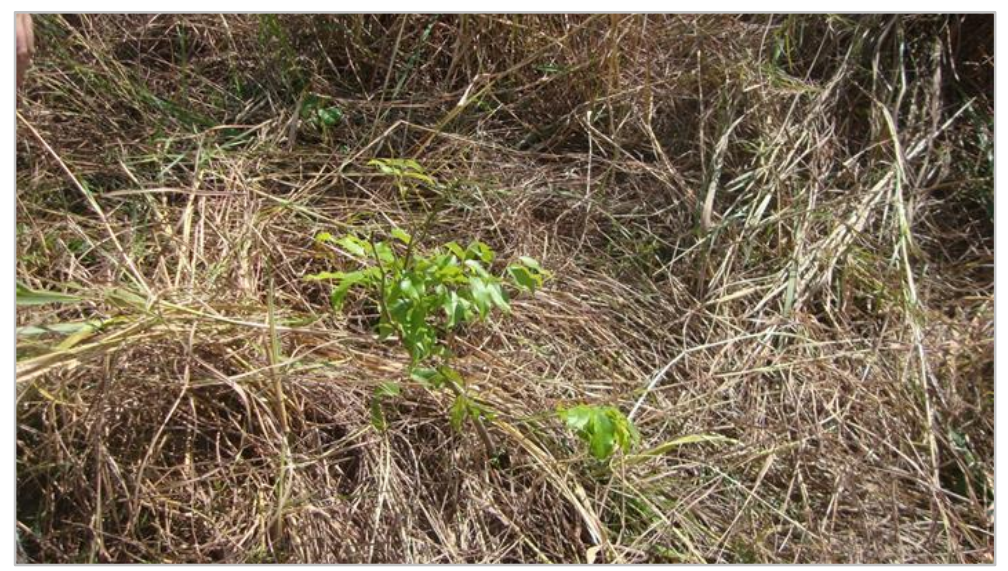

Fotografia 2 - Muda de árvore no meio do colonião em Mbopiy, Te'ýikue. Fonte: Autoria própria.

Para a professora não indígena de Te'ýikue, após o ciclo da erva-mate veio o modelo das fazendas de gado e junto com elas a braquiária para alimentar os animais. Então, desmatavam para as pastagens. Segundo seu relato:

Aí trouxeram trator pros ervais pra ir tirando e levava tudo pelo meio do caminho. Foi destruindo. Eles viam os fazendeiros fazendo na região e sem fazer uma reflexão foram fazendo aqui. Não sei quem financiou isso. Houve incentivo pra criar gado. Trouxe semente da braquiária, em que planta uma 
vez, não precisa ficar cuidando pra fazer pastagem. Planta uma vez e vai embora. Eles plantaram braquiária achando que era uma coisa boa.

Ela prosseguiu afirmando: “onde há sombra não há braquiária, nem sapé. O cupinzeiro também não se dá com a mata. O cupim se alimenta da raiz da braquiária. Onde a natureza tá detonada, em que só há braquiária se vê um monte de cupim". Os cupinzeiros e formigueiros também fazem parte da paisagem nas terras indígenas, em alguns espaços parecem colônias, tamanha a sua concentração em áreas devastadas. A mesma professora completou: "em lugar destruído onde tem braquiária é lá que o cupim sobrevive. O SAFE (com a adubação de compostos orgânicos) é uma forma de combater a braquiária. E faz a plantação em consórcio com várias culturas".

Já o rezador de Mbokaja, em Te'ýikue, revelou que: "aí braquiária trouxe a gente mesmo quando ia trabalhar na fazenda. Trouxe no pé, a semente da braquiária. Aí espalhou". Interessante este registro, pois, revela que o trabalho temporário nas fazendas (changa) ocasionou uma das causas da infestação da braquiária nas terras indígenas, ou seja, a presença da semente nos sapatos dos trabalhadores indígenas que ao retornarem para casa traziam a braquiária "no pé".

Segundo a visão do professor da unidade experimental da escola em Te'ýikue, foram os fazendeiros que trouxeram a braquiária porque as fazendas estão próximas: "eles plantam pra pastagem e as sementes acabam vindo pelo vento, pássaros. Aí foi tomando conta". Sobre as formas de combater a braquiária e o colonião, a orientação da unidade é utilizar o adubo verde. E, indicou as espécies: "tem o guandu, o feijão de porco (curé), a mucuna que são feijões que vão subindo e fazem aquela sombra e vai abafando a braquiária porque ela não gosta de sombra. Ela vai morrendo".

Para o rezador de Sucuruíy quem jogou a braquiária na terra foram os fazendeiros. Perguntei se existe reza para acabar com a braquiária. Ele respondeu: "não tem. Não tem jeito". Então, como fazer para tirar a braquiária e a terra nascer de novo, as coisas da terra daqui? Ele afirmou: "só acabar mundo e Deus esse aqui terra vai virar. Terra nova. Mato novo. Acaba pessoa, acaba mundo. Faz tudo novo. Pessoal novo. Terra novo. Mato novo. É o que vai acontecer". E prosseguiu com seu pensamento: "O mundo pra acabar é difícil. As pessoas sim, o mundo não. Vai acontecer".

Em Jatayvary, a liderança também confirmou que não existe reza para acabar com a braquiária. Diante da pergunta: Reza serve pra braquiária? Ao que ele respondeu: "Só serve o trator. Não tem reza. Produzir, se alimentar é no muque, né. Mas produzir o dinheiro tem que ser na máquina".

Nestas conversas há uma unanimidade de que não há reza para acabar com a braquiária, ou seja, ela não existe ou não é conhecida. O que revela como a introdução de elementos externos pode afetar a manutenção dos equilíbrios promovidos pela 
espiritualidade do povo. A inexistência ou o desconhecimento da reza não oferece respostas para atenuar/exterminar algo que afeta a qualidade da terra, da agricultura, da paisagem e que gera dependência de fontes externas como o trator e o combustível.

Respeitadas algumas variações e níveis de intensidade, parece uma constante a presença de um ciclo que revela os seguintes aspectos: desmatamento - fazenda de gado com introdução da braquiária - fogo para combater a braquiária e fazer roça desmatamento ampliado.

Sobre o monocultivo da cana-de-açúcar, a terra que mais sente os seus efeitos é Jatayvary (capítulo 5), pois, existem plantações no seu entorno e dentro da área que foi identificada e delimitada como indígena. Além disso, há uma usina a poucos quilômetros da área em que vivem. No entanto, outros aspectos podem ser sentidos, como a presença de caminhões que cortam as terras indígenas ou no seu entorno; poluições de todas as ordens: dos corpos hídricos, do ar, do solo e sonora e dos aspectos sociais referentes ao trabalho dos homens no corte da cana-de-açúcar.

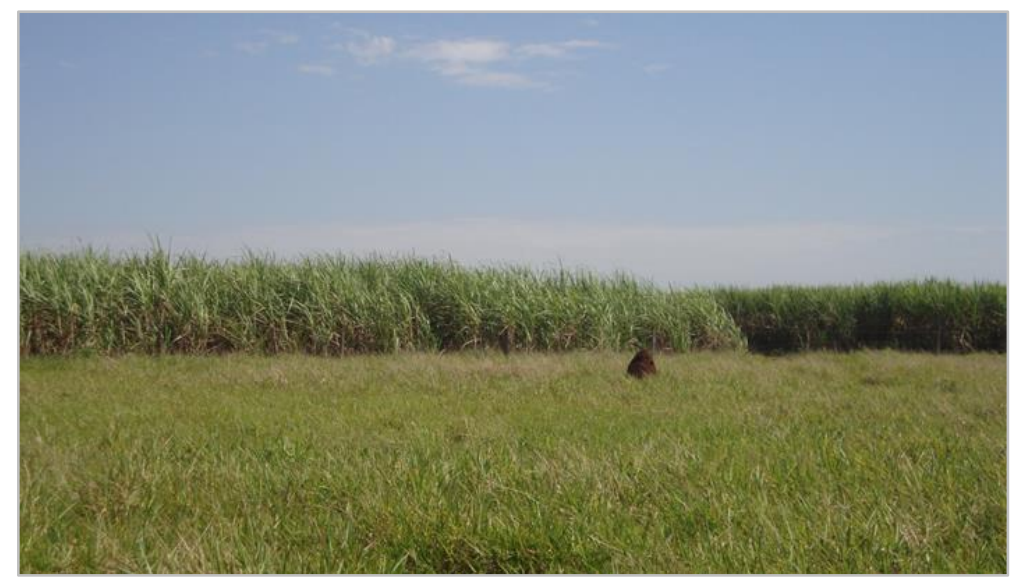

Fotografia 3 - Plantação de cana-de-açúcar, braquiária e formigueiro em Jatayvary.

Fonte: Autoria própria.

Sobre a deposição de resíduos sólidos, os municípios não realizam o serviço de coleta nas terras indígenas. No máximo, o caminhão que recolhe o lixo passa uma vez por semana nas escolas. Então, a maioria das famílias abre um buraco na terra e queima o lixo, que, hoje em dia, é bem diversificado, com dejetos plásticos, de metal, alumínio, dentre outros. Em Te'ýikue o caminhão de coleta da prefeitura passa uma vez por semana na escola, mas próximo ao viveiro de mudas há um lugar onde é realizada a queima lixo.

Diante deste quadro, percebi determinados problemas ambientais que comprometem a terra pela herança colonial em diversos contextos de expansão econômica da região, gerando degradação, tais como: desmatamento; introdução de espécies invasoras como braquiária e colonião; desequilíbrio ambiental com superpopulação de formigas, de cupins e 
de outras pragas; solos degradados; rios e córregos assoreados; redução/extinção de espécies; poluição de corpos hídricos; uso de agrotóxico e outros defensivos químicos; dependência de insumos, como trator e outros na prática da agricultura; arrendamento de terras para uso de práticas de agricultura das fazendas do entorno e ampliação do consumo com geração de resíduos difíceis de serem absorvidos pela terra.

A herança colonial gerou um passivo de problemas ambientais que foram sendo introduzidos e acumulados no decorrer das diversas fases colonizadoras através da espoliação das terras tradicionais. O tempo de recuperação natural da terra não é respeitado. A voracidade da exploração dos elementos/recursos da natureza em atividades econômicas esteve dissociada de dimensões socioculturais. Conforme demonstra, um recente atlas socioambiental do território da grande Dourados:

A porção sul do estado de Mato Grosso do sul se consolidou, ao longo das
últimas décadas, como uma das mais importantes áreas de produção
agrícola do Brasil, cujos reflexos podem ser observados, sobretudo, pelo
desenvolvimento econômico proporcionado por esta atividade nas cidades
da região da Grande Dourados. Por outro lado, porém, a utilização
econômica a que foram submetidos os recursos naturais, distantes de uma
preocupação com os princípios de sustentabilidade ambiental, implicaram
na geração de uma série de passivos ambientais que começam a
comprometer a capacidade desses mesmos recursos em continuar
sustentando os atuais níveis de desenvolvimento da região (ESAT-GT,
2012, p. 5).

Tudo isso em meio a uma frágil normatização que viesse a proteger não só as populações indígenas como também o meio ambiente. Historicamente, o direito brasileiro protege a propriedade individual, estimulando uma produtividade que explora os elementos naturais sem levar em consideração as suas valorações intrínsecas; os impactos multidimensionais dos projetos econômicos e a capacidade de recuperação dos "recursos ${ }^{44 "}$ ambientais.

Se levarmos em consideração a normatização que tratou de questões ambientais da primeira Constituição Republicana (de 1891) até a Constituição de 1988, foram raros os textos que incorporaram uma visão coletiva de meio ambiente. Mesmo após o considerável avanço normativo ocorrido a partir das regulamentações da chamada Constituição ambiental ou verde (1988) e da burocratização de órgãos que compõem o SISNAMA em todos os níveis da federação, a chamada "questão ambiental" continua sendo uma questão marginal do ponto de vista das políticas institucionais de governo. O que se reflete em baixo orçamento e em perdas quando há disputa com outras pautas mais econômicas, pois, também continua a prevalecer uma visão setorial da temática, mesmo havendo uma incorporação do discurso da interdisciplinaridade nas legislações pós-1988.

\footnotetext{
${ }^{44}$ Esta é a razão pela qual prevaleceu e prevalece a ideia de meio ambiente como recurso econômico no sentido de monetarização do mesmo.
} 


\section{SUSTENTABILIDADE DA VIDA NA TERRA}

\subsection{SUSTENTAR A TERRA}

\subsubsection{Sustentabilidade substantiva, sustentabilidades adjetivas ${ }^{45}$}

Apesar do debate e do conhecimento sobre meio ambiente ter avançado bastante nas últimas décadas, observa-se que as pressões sobre os ecossistemas também cresceram, assim como as diversas formas de ocupação do homem no espaço físico-territorial, gerando um aprofundamento da crise na disponibilidade, no acesso e na utilização dos bens naturais. Os limites naturais do planeta parecem ofuscar a racionalidade econômica e política. O crescimento econômico contínuo e ilimitado se contrapõe a um meio ambiente finito.

No território ${ }^{46}$ estão presentes muitas disputas de poder pela reapropriação da natureza $^{47}$, neste espaço existem muitas "racionalidades". Leff a partir do conceito de racionalidade ${ }^{48}$ em Weber constrói um conceito de racionalidade ambiental passando pela crítica da racionalidade econômica capitalista tecno-científica rumo a um encontro ou diálogo de racionalidades que vão além da mera razão e por diferentes formas de imaginar, sentir, significar e valorar as pessoas e coisas do mundo. A racionalidade ambiental se constrói a partir da articulação de quatro níveis de racionalidade: substantiva, teórica, técnica ou instrumental e cultural. O que implica na valorização de: "pluralidade étnica, racionalidades culturais, economias autogestacionárias não acumulativas e diálogos de saberes" em contraposição a meios instrumentais. Seria uma articulação de processos ecológicos, culturais e tecnológicos (LEFF, 2006, p. 262).

A crítica à racionalidade econômica hegemônica, consistente na mercantilização da natureza, na modernização ecológica e nos valores da produtividade e da eficiência pode conduzir a uma outra racionalidade que leve a sustentabilidade. As diferenças entre as

\footnotetext{
${ }^{45} \mathrm{O}$ título foi inspirado em Boff (2012a, p. 9) no qual ele coloca que sustentabilidade "como substantivo exige uma mudança de relação para com o sistema-natureza, sistema-vida e o sistema-Terra", enquanto que, "como adjetivo, a expressão sustentabilidade é agregada a qualquer coisa sem mudar a natureza desta".

${ }^{46}$ Por isso, é importante não perder de vista que: "el território es cultura-naturaleza, lugar-soporte de la existencia humana. El territorio es el espacio-tiempo en el que se expresan los procesos de apropiación de la naturaleza en su organización ecogeográfica, pero sobre todo es el lugar donde se reconstruyen los modos de habitar el mundo desde racionalidades diferenciadas y alternativas" (LEFF, 2014, p. 467).

47 "A reapropriação da natureza é uma ressignificação da natureza nas sendas da vida aberta pela existência. Implica um pensamento, mas também tomar a palavra para renomear, ressignificar e dar novos sentidos à vida cultural em sua conexão com a ordem natural, para fazer manifesto o ente desde o ser através da linguagem, para reincorporar-se ao mundo através do discurso" (LEFF, 2006, p. 445).

${ }^{48}$ Nesse contexto, a racionalidade social é definida como: "o sistema de regras de pensamento e ação que se estabelecem dentro de esferas econômicas, políticas e ideológicas, legitimando determinadas ações e conferindo um sentido de organização da sociedade em seu conjunto. Essas regras orientam processos, práticas e ações sociais para determinados fins, através de meios socialmente construídos, que se refletem em sistemas de crenças, normas morais, acertos institucionais e padrões de produção" (LEFF, 2006, p. 243).
} 
racionalidades econômica e ambiental são o que determinam as estratégias de apropriação da natureza. Uma vez que:

\begin{abstract}
a submissão da natureza às leis do mercado coloca em risco a preservação do equilíbrio ecológico e da complexidade organizativa que sustenta sua coevolução com as diversas culturas que integram a raça humana. A organização das culturas e dos ecossistemas aparece assim como condição de sustentabilidade, como um conjunto de princípios criativos e potenciais produtivos que orientam a reconstrução social diante da racionalidade econômica que domina o valor da vida e o sentido da existência (LEFF, 2006, p. 263).
\end{abstract}

Para Leff (1994, p. 103-4) "la racionalidad económica dominante se caracteriza por el desajuste entre las formas y ritmos de extracción, explotación y transformación de los recursos naturales y las condiciones ecológicas para su conservación, regeneración y aprovechamiento sustentable". A uniformização de cultivos e redução da biodiversidade está associada a este tipo de racionalidade. Diferentemente das economias indígenas e campesinas que possuem uma racionalidade não-cumulativa. Leff (1994, p. 175) situando suas análises na América Latina, conclui que:

La racionalidad de la producción rural y de las economías de autosubsistencia integran valores culturales orientados por objetivos de estabilidad, prestigio, solidariedad interna y satisfacción endógena de necesidades, así como normas sociales de acceso de la comunidad y de distribución equitativa de los recursos ambientales. Esta racionalidad productiva se contrapone a la especialización y homogeneización de la naturaleza y a la maximización del beneficio económico en el corto plazo.

Porto-Gonçalves (2004, p. 58-60) também coloca o território como uma questão central para o debate do desafio ambiental contemporâneo. É emblemática a sua afirmação de que "o Estado territorial moderno tende a ser monocultural". Em um contexto, no qual "a colonialidade é mais que o colonialismo". A propriedade privada instaura "a ideia de territórios mutuamente excludentes". A acessibilidade aos recursos naturais, "revelará a natureza das relações sociais de poder entre os do lugar e os de fora do lugar onde se encontram". E tudo isto é revelador das "relações de pertencimento e estranhamento (um nós e um eles), assim como relações de dominação e exploração, através do espaço, pela apropriação/expropriação de seus recursos" (Idem).

Um desenvolvimento que leve em consideração a vida das pessoas e do meio ambiente ainda é bastante desigual e injusto. Por isso, neste contexto, ainda são reveladoras as ideias do icônico "Small is Beautiful" de Schumacher (1981), pois, em um mundo em que ser "grande" é a meta da maioria dos países e das suas populações, a Terra tem se tornado um lugar "pequeno" para a voracidade das nossas "necessidades". 
O termo ecodesenvolvimento foi proposto por Maurice Strong e aprofundado por Ignacy Sachs ${ }^{49}$, mas paulatinamente foi sendo substituído pela expressão desenvolvimento sustentável que passou a ser utilizada em documentos internacionais ligados a atividades do PNUMA. A definição institucional mais adotada é a da proposta da CMMAD, conhecida como comissão Brundtland que em 1987, no seu relatório chamado de Nosso Futuro Comum, fixa o desenvolvimento sustentável como "aquele que atende às necessidades do presente sem comprometer a possibilidade das gerações futuras de atenderem as suas próprias necessidades" (BARBIERI, 2000, p. 23). Por ocasião da CNUMAD, conhecida como Rio ou Eco/92, a Declaração do Rio sobre Meio Ambiente e Desenvolvimento, incorporou no seu texto o termo desenvolvimento sustentável.

Sachs (2008, p. 85-8) identifica vários critérios de sustentabilidade, são eles: social; cultural; ecológico; ambiental; territorial; econômico e político (nacional e internacional). Três destas dimensões ficaram discursivamente mais populares e passaram a formar o modelo do tripé da sustentabilidade. As dimensões foram adjetivadas e para se alcançar a sustentabilidade, o desenvolvimento deveria ser harmonicamente: socialmente justo, economicamente viável e ecologicamente correto. Se isto ocorrer, teremos uma sustentabilidade forte; caso contrário, a sustentabilidade será fraca, pois, um dos tripés estará mais em evidência que o outro, geralmente, o econômico, formando o que alguns autores chamam de esquema Mickey Mouse ${ }^{50}$.

Para além das três consagradas dimensões do desenvolvimento sustentável: econômica, ambiental e social; existem muitas faces que nem sempre são colocadas abertamente nos processos decisórios sobre atividades e empreendimentos que causam profundas transformações nos territórios urbanos ou rurais. Como lembra Pinheiro do Nascimento (2012a, p. 51) o desenvolvimento sustentável:

se tornou um campo de disputa, no sentido utilizado por Bourdieu, com múltiplos discursos que ora se opõem, ora se complementam. O domínio da polissemia é a expressão maior desse campo de forças, que passa a condicionar posições e medidas de governos, empresários, políticos, movimentos sociais e organismos multilaterais.

O campo interdisciplinar da sustentabilidade possui regras próprias, regularidades, agentes identificáveis e formas exclusivas. A noção de campo, que também é um espaço

\footnotetext{
${ }^{49}$ Sachs em 1972 estava engajado na preparação da Conferência das Nações Unidas para o Meio Ambiente, em Estocolmo, em que duas posições ficaram muito evidentes: a dos partidários do crescimento selvagem e a dos diferentes partidários do crescimento demográfico zero. De acordo com o seu balanço, esse primeiro encontro mundial promovido pela ONU para tratar desse tema foi fundamental para a articulação do social, do meio ambiente e do econômico, além de, a partir dela, ter sido criado o PNUMA. O secretário-geral da conferência, Maurice Strong, lançou o termo "ecodesenvolvimento". Nos anos seguintes, Sachs conduziu uma missão das Nações Unidas sobre uma estratégia de longo prazo para a Amazônia peruana, onde foi produzido seu primeiro texto sobre ecodesenvolvimento; participou do colóquio de Cocoyoc, no México em 1974, onde a discussão sobre subdesenvolvimento implicava em parar o sobredesenvolvimento dos ricos, o que gerou uma má apreciação da palavra ecodesenvolvimento e uma substituição progressiva por desenvolvimento sustentável (SACHS, 2009, p. 230-247).

${ }^{50}$ Vide BURSZTYN, BURSZTYN (2012, p. 51-2) para a visualização destes esquemas.
} 
de luta no microcosmo do macrocosmo social, reside em um jogo com regras que seguem e mudam conforme os atores agem nas suas relações sociais. No campo específico da sustentabilidade há diversos agentes com diferentes saberes e práticas que se unem em torno da "preocupação com o futuro da humanidade", cujas concepções, muitas vezes, são diversas e contraditórias.

A ideia de ameaça à humanidade permite quatro leituras, que vão da mais radical a moderada: a) a de que a Terra estaria ameaçada pelo aquecimento global; b) a de que a vida estaria ameaçada pelo aquecimento global e pela destruição dos recursos naturais; c) a de que o gênero humano seria extinto pelo aquecimento global e outros fatores; d) a da degradação das condições de vida de grande parte da humanidade por fatores ambientais, sociais e econômicos. Para enfrentar essas ameaças, Pinheiro do Nascimento (2012b) sistematiza três correntes de pensamento: a) a de que o desenvolvimento econômico traz bem-estar e as inovações tecnológicas irão utilizar menos recursos e energia, representada por R. Solow; b) a de que o atual modelo de desenvolvimento é autodestrutivo, por isso, propõe-se um decrescimento com a construção de novos valores, representada pelo relatório do Clube de Roma, por N. Georgescu-Roegen e Serge Latouche; c) a do desenvolvimento sustentável, corrente hegemônica, sintetizada pelo Relatório Brundtland.

Diversos setores econômicos incorporaram nas últimas duas décadas discursos de sustentabilidade para atender, em grande medida, as necessidades de financiamento, do cumprimento de normas e as novas exigências consumeiristas. Valendo-se da abertura semântica do conceito normativo de desenvolvimento sustentável, estabelecido no Relatório Brundtland, a sua apropriação, em grande medida, tem ocorrido de modo vago e banalizado.

O desenvolvimento sustentável, conforme análise de Hannigan (2009, p. 61) situa-se num âmbito do discurso como "categoria mais geral da produção linguística e abrange um número de outras táticas e métodos incluindo a narrativa (escrita e oral) e a retórica". Neste sentido, é perspicaz a discussão do "free-rider discursivo", com base na lógica da ação coletiva de M. Olson, em que Bursztyn e Ferraz da Fonseca fazem ao analisarem a teoria e a prática dos discursos de sustentabilidade.

O "free-rider discursivo" (aplicado à questão ambiental) é aquele que, ao
manifestar apoio discursivo ao desenvolvimento sustentável, desfruta dos
benefícios de ser "ecologicamente correto" sem de fato sê-lo; ou seja, é
aquele que se apropria dos bens simbólicos sem que essa adesão
discursiva tenha respaldo na prática, que continua sendo guiada por
interesses individuais. (BURSZTYN, FERRAZ DA FONSECA, 2007, p. 181).

As críticas ao desenvolvimento sustentável, mesmo com a sua consolidação discursiva, surgem no contexto em que se verifica a ampliação da degradação ambiental, principalmente pela diminuição da biodiversidade e pelo aumento das emissões de $\mathrm{CO}^{2}$ e do 
hiperconsumo. Surgem outras abordagens ou releituras de análises pretéritas em que questões éticas e de justiça se entrelaçam com a questão ambiental. Mas o mágicoespiritual ainda é uma dimensão ignorada no discurso e práticas ditas sustentáveis.

Dentre as diversas abordagens, destaca-se uma que está centrada no desenvolvimento visto como um processo de expansão das liberdades substantivas das pessoas. Isto requer uma compreensão integrada das instituições e dos seus valores para alcançar o desenvolvimento como liberdade de acordo com a proposta de Sen (2000). Seu enfoque nas liberdades humanas ${ }^{51}$ contrasta com visões mais restritas de desenvolvimento, como àquelas que o identificam com crescimento meramente econômico, por exemplo, o PNB, porque as liberdades dependem de outros fatores, como os direitos civis, sociais e econômicos.

Daly, um dos economistas mais críticos tanto da economia convencional quanto do desenvolvimento sustentável, defende a ideia de que o termo desenvolvimento sustentável muito usado como um sinônimo para o oxímoro crescimento sustentável, só faz sentido para a economia se for entendido como desenvolvimento sem crescimento ${ }^{52}$, ou seja, "a melhoria qualitativa de uma base econômica física que é mantida num estado estacionário pelo transumo de matéria-energia que está dentro das capacidades regenerativas e assimilativas do ecossistema" (DALY, 2004, p. 198).

Neste contexto, é emblemática a obra de Karl Polanyi (2000) que trata da formação do processo da economia de mercado autorregulável dissociado das transformações sociais, que atingiram a sua plenitude no século XIX, baseada em estudos da Revolução Industrial e de suas consequências na civilização moderna. A crença no progresso econômico relegou os acontecimentos sociais a um plano inferior, gerando grandes desarticulações.

Nas duas grandes guerras ocorreram crises no sistema econômico internacional. As transformações ocorreram na terra, no trabalho e no dinheiro, na medida em que passaram a ser mercadorias numa sociedade que se industrializava cada vez mais dependente de leis como oferta e procura em esferas interligadas de comércio. Segundo Polanyi (2000, p. 107): "o pauperismo fixou a atenção no fato incompreensível de que a pobreza parecia acompanhar a abundância".

O contramovimento ao liberalismo econômico deu origem ao princípio da proteção social, que visou preservar o homem (com sua mão-de-obra colocada à venda pelo salário)

\footnotetext{
${ }^{51}$ Para Sen (2000), há duas razões pelas quais a liberdade é central para o processo de desenvolvimento: a avaliatória (a avaliação do progresso tem que ser feita verificando-se se houve aumento da liberdade das pessoas) e a da eficácia (a realização do desenvolvimento depende inteiramente da livre condição de agente das pessoas).

52 Para Daly (2004, p. 198), "crescer significa "aumentar naturalmente em tamanho pela adição de material através de assimilação ou acréscimo". Desenvolver-se significa: "expandir ou realizar os potenciais de; trazer gradualmente a um estado mais completo, maior ou melhor". "Quando algo cresce fica maior. Quando algo se desenvolve torna-se diferente. O ecossistema terrestre desenvolve-se (evolui) mas não cresce. Seu subsistema, a economia, deve finalmente parar de crescer mas pode continuar a se desenvolver".
} 
e a natureza (entendida como terra regulada pelo mercado), bem como apoiar as classes trabalhadoras e fundiárias na sua organização produtiva. Isto gerou o desenvolvimento de algumas normas protetivas ao trabalhador e ao meio ambiente. O sistema econômico do estado liberal difere significativamente da economia das chamadas sociedades primitivas, em que a reciprocidade, a redistribuição e a domesticidade da produção para uso próprio são as suas características marcantes.

As discussões sobre sistemas econômicos e ecologia política caminham juntas. Com diferentes nuances, há certo consenso de que os sistemas econômicos hegemônicos aprofundaram a crise ecológica contemporânea a partir da Revolução Industrial. Nas abordagens sobre a relação entre comunismo e natureza há basicamente duas posições sobre a compatibilidade do pensamento de Marx ${ }^{53}$ com a ecologia moderna: a) não há como extrair um pensamento ecológico da teoria marxista; b) há como fazer uma análise ecológica através da crítica ao capitalismo em Marx.

De toda forma, a exploração desenfreada da natureza, vista como recurso, é uma tônica do processo de industrialização, não sendo uma característica identificada apenas ao capitalismo. Como lembra Bursztyn e Bursztyn (2012, p. 76): "os países do bloco soviético, que durante várias décadas ao longo do século XX implantaram sistemas de produção e de infraestrutura segundo princípios socialistas também protagonizaram grandes desequilíbrios ecológicos".

Uma construção teórica que tem ganhado um maior nível de discussão na academia de vários países e, que aos poucos tenta se inserir na representação da pauta política é a ideia de decrescimento ${ }^{54}$. Segundo Latouche (2009), um dos seus precursores, é necessário observar que existem diversos níveis de decrescimento a serem aplicados segundo o modelo de desenvolvimento de cada país. Neste contexto, quem deve decrescer são as populações de alta renda, que existem tanto nos chamados países mais desenvolvidos como nos menos desenvolvidos. Essa ideia vai além dos modelos economicistas, por isso, é considerada como uma alternativa aos modelos tradicionais de crescimento e

\footnotetext{
${ }^{53}$ Para Löwy (2005, p. 37-8): "Não resta dúvida de que falta a Marx e Engels uma perspectiva ecológica de conjunto. Por outro lado, é impossível pensar em uma ecologia crítica à altura dos desafios contemporâneos sem ter em conta a crítica marxiana da economia política, o questionamento da lógica destrutiva induzida pela acumulação limitada de capital. Uma ecologia que ignora ou negligencia o marxismo e sua crítica do fetichismo da mercadoria está condenada a não ser mais do que uma correção dos "excessos" do produtivismo capitalista". Foster (2011) é mais enfático ao identificar as preocupações ecológicas em Marx. Para este autor, "desde o princípio, a noção de Marx da alienação do trabalho humano esteve conectada a uma compreensão da alienação dos seres humanos em relação à natureza" (FOSTER, 2011, p. 23). Ele reconhece que descobriu a ideia de que: "foi a investigação sistemática da obra do grande químico agrícola alemão Justus von Liebig, partindo da sua crítica do malthusianismo, que levou Marx ao seu conceito central da "falha metabólica" na relação humana com a natureza - sua análise madura da alienação da natureza" (FOSTER, 2011, p. 10).

${ }^{54}$ Para Latouche (2009) o círculo virtuoso do decrescimento sereno é composto por vários " $r$ ", como: reavaliar os valores; reconceituar a riqueza e a pobreza; reestruturar o aparelho produtivo e as relações sociais; redistribuir a riqueza e o acesso ao patrimônio natural entre Norte e Sul, dentro de cada sociedade, classes, gerações e indivíduos; relocalizar os produtos necessários à satisfação da população; reduzir o consumo excessivo e o desperdício; reutilizar e reciclar.
} 
desenvolvimento. É voltada para o respeito aos limites ecológicos do planeta, de modo que os recursos naturais sejam usufruídos de modo mais equânime pela sociedade mundial.

A ideia de uma outra sustentabilidade ou uma sustentabilidade substantiva, sem adjetivos faz parte do contexto de críticas sobre o debate do desenvolvimento sustentável. Neste sentido, muitos foram os documentos internacionais produzidos sobre meio ambiente e desenvolvimento sustentável, mas dentre eles, um se destina a pensar a terra como uma comunidade de vida na diversidade, destacando-se por seu caráter ontológico e existencialista. Em dezesseis princípios, a Carta da Terra (sua íntegra encontra-se no Anexo), aprovada em 2000 pela UNESCO, trata do respeito e do cuidado ${ }^{55} \mathrm{com}$ a comunidade da vida; da integridade ecológica; da justiça social e econômica; da democracia; da não-violência e da paz. Nela, há um reconhecimento dos fortes processos de degradação da Terra, daí a necessidade de um "novo começo", mas para isto ocorrer é imperioso transformar mentes e corações para criar um modo sustentável de vida com responsabilidade em todos os níveis, do local ao global.

Há uma diferença de origem e de uso para os termos sustentabilidade e desenvolvimento sustentável. Boff (2012c, p.31-3) traça um caminho da sustentabilidade desde seu significado etimológico, proveniente da palavra latina sustentare, que significa sustentar; passando por seu significado em dicionários: destacando um sentido passivo, como suportar ou segurar por baixo e, um sentido ativo, como conservar, proteger e viver; até o seu primeiro registro na Alemanha, em 1569, empregado na silvicultura para o manejo de florestas. Já desenvolvimento sustentável, como visto, passou a ser empregado institucionalmente a partir do Relatório Nosso Futuro Comum ou Brundtland, em 1987 pelo PNUMA. A partir daí os documentos da ONU, dos governos nacionais, das empresas, das ONG's e da mídia passaram a adotar esta designação.

Também foram muitos os adjetivos dados à concepção de sustentabilidade ${ }^{56}$. Ao criticar os atuais modelos de sustentabilidade, Boff (2012c) identifica o modelo-padrão de sustentabilidade ao de uma sustentabilidade retórica; o modelo do neocapitalismo a ausência de sustentabilidade; o modelo do capitalismo natural a uma sustentabilidade enganosa; o modelo da economia verde a sustentabilidade fraca e o modelo do ecossocialismo a sustentabilidade insuficiente. $\mathrm{E}$, aponta alguns caminhos de esperança ao vislumbrar o modelo do ecodesenvolvimento de Sachs e a bioeconomia de GeorgescuRoegen como sendo a sustentabilidade possível; o modelo da economia solidária como

\footnotetext{
${ }^{55}$ Segundo Boff (2012b, p. 22-9) a palavra cuidado vem do latim cura, significando cuidar e tratar. Refere-se a um sentimento de mútua pertença, ou seja, cuidar e ser cuidado. Seu uso foi primeiramente aplicado na área de saúde, depois na educação, passando pela filosofia e teologia, constituindo uma discussão ecológica central na Carta da Terra. Para conhecer os quatro sentidos de cuidado, vide BOFF (2012b, p. 34-7).

${ }^{56}$ Para uma revisão dos adjetivos e predicados atribuídos a noção de desenvolvimento, vide: BARRETO FILHO (2006).
} 
sendo a microssustentabilidade viável e o bem-viver dos povos andinos como a sustentabilidade desejada.

A proposta de Boff (2012c) é de uma sustentabilidade integradora que leve em consideração pressupostos cosmológicos e antropológicos, tendo como componente o cuidado essencial com a Terra, valorizando a sua dimensão espiritual, bem como a do universo e do ser humano. Independentemente da concepção que se tenha de sustentabilidade, a ideia motora é que:

Não é correto, não é justo nem ético que, ao buscarmos os meios para a nossa subsistência, dilapidemos a natureza, destruamos biomas, envenenemos os solos, contaminemos as águas, poluamos os ares e destruamos o sutil equilíbrio do Sistema Terra e do Sistema Vida. Não é tolerável eticamente que sociedades particulares vivam à custa de outras sociedades ou de outras regiões, nem que a sociedade humana atual viva subtraindo das futuras gerações os meios necessários para poderem viver decendemente (BOFF, 2012c, p. 64-5).

$\mathrm{Na}$ visão de sustentabilidade de Boff, destaca-se a ética do cuidado e o princípio da prevenção e da precaução. A definição integradora de sustentabilidade de Boff pretende ser holística, sistêmica, eco e biocêntrica e, resulta na compreensão de que é:

Toda ação destinada a manter as condições energéticas, informacionais, físico-químicas que sustentam todos os seres, especialmente a Terra viva, a comunidade de vida e a vida humana, visando sua continuidade e ainda atender as necessidades da geração presente e das futuras, de tal forma que o capital natural seja mantido e enriquecido em sua capacidade de regeneração, reprodução e coevolução (BOFF, 2012c, p. 107).

Mas como criar sustentabilidade em um mundo insustentável? As desigualdades no campo econômico e social também se estendem ao campo ambiental, ampliando as injustiças e aprofundando as crises. Neste contexto, a busca por modelos torna-se uma tônica, em que os modelos indígenas (que também tem suas crises, pois, passam e passaram por diversos processos de colonização e de relações interétnicas) são considerados por parte de muitos autores e movimentos ecológicos como inspiradores e detentores de saberes e de sensibilidades; de relações mais profundas, sábias e holísticas com a terra. E, de certa forma, representam a busca de uma essência perdida, esquecida ou subjugada pelos modelos econômicos dos quais somos herdeiros.

Muitas sociedades indígenas não usam o discurso da sustentabilidade, mas suas práticas poderiam aos olhos dos analistas serem vistas como tal. Conforme Azanha (2005, p. 15), sustentar-se, para estas sociedades, "significa manter o equilíbrio das trocas com o mundo natural (e sobrenatural) visando à segurança dos parentes mais próximos e repondo, no processo, os estoques de corpos humanos, das almas e dos seres (recursos) "naturais"”.

Entendo que para os kaiowá-guarani a sustentabilidade da terra está profundamente ligada à espiritualidade que orienta o seu modo de ser. $O$ profundo conhecimento que 
possuem da terra leva ao cuidado e respeito, numa relação de interdependência entre todos os seres. Conforme Eliel Benites (2014, p. 67):

Todos os seres existentes, os animais, as plantas, a natureza são representações físicas da espiritualidade. Dessa forma podemos nos conectar com as plantas, os animais e a natureza em geral, se compreendermos as linguagens da própria espiritualidade, a partir das outras sensibilidades que foram apagadas pela racionalidade e objetividade de percepção de mundo. A espiritualidade é o pensamento e a lógica dos Kaiowá e Guarani.

No trabalho de recuperação ambiental que resultou na construção de um Atlas da terra indígena de Te'ýikue, foi registrado que:

Nós, Kaiowá e Guarani, tradicionalmente sabíamos da interdependência entre os elementos na natureza. Não separávamos o mundo natural, o espiritual e o social. Nossos costumes respeitam essas relações. Rituais, rezas e cantos, que acompanhavam a coleta, a caçada e o plantio da roça confirmam isso. Não plantávamos sempre no mesmo lugar e sabíamos os locais adequados para cada tipo de planta. Não deixávamos esgotar o solo, mantendo-o sempre em condições de ser utilizado em novo plantio" (UCDB, 2009, p. 4).

A cosmologia dos kaiowá-guarani que alimenta o seu modo de ser conduz a algo que, na minha interpretação, pode ser descrito como uma sustentabilidade da vida ${ }^{57}$. Partindo de uma ontologia da diversidade, onde natureza e cultura coexistem na complexa construção de territorialidades, Leff (2014, p. 492-3) propõe que a sustentabilidade da vida se concretiza: "en el encuentro y convergencia de las diferentes matrices de racionalidad cultural, en un diálogo de saberes que constituyen diferentes seres culturales en su relación con sus imaginarios, sus saberes y prácticas, en sus entornos habitados".

\subsubsection{Percepções de topofilia: fenomenologia do pertencer}

Um dos caminhos analíticos adotados neste trabalho é o de que a noção de pertencimento, calcado na filosofia da fenomenologia e da percepção, conduz a sustentabilidade da vida baseada em fortes vínculos entre o humano e a terra que habita com todos os demais seres.

Inicialmente a percepção como "objeto científico" teve seu desenrolar a partir de estudos no campo da fisiologia e da psicologia. Mas foi na fenomenologia que encontrou um campo fecundo para pesquisas e investigações. Como aponta Escobar (2011, p. 59):

Como filosofia de la experiencia, el objeto de estudio de la fenomenología es el ser-en-el mundo, es decir, antes de que los fenómenos sean capturados por el pensamiento y sin su reducción a cualquier verdad o

\footnotetext{
57 Sobre esse tema, discorrem Leonardos e Costa (2008, p. 113): "À beira do abismo, parte de nossa cultura nada mais sabe sobre a sabedoria da Terra e a sustentabilidade da vida. Mas, dentro dela, há alguns mais sensíveis, ligados à arte ou à ciência que em momentos de silêncio interior, de sonho, devaneio ou poesia, acessam conhecimentos maiores do que podem verbalizar, momentos de iluminação e criatividade onde se redescobre algo que nos traz novo sentido". Vide também: LEONARDOS, BILIBIO (2012b).
} 
esencia transcendental. En lugar de intentar dar con una visión objetiva de la realidad, la fenomenología comienza con la hipótesis de que el mundo es primero y después conocido, y que es mundo-vida (como dominio de la existencia social cotidiana y la actividad práctica), más que una visión del mundo, lo que cuenta en la explicación de la forma en que el mundo se nos presenta. De este modo, la fenomenología prioriza la experiencia vivida por encima de los conocimientos teóricos, considera diversos tipos de conocimientos en pie de igualdad y reconoce que el sujeto siempre está implicado en el mundo y en el conocimiento mismo.

O pertencer passa pelo perceber, conceito que envolve ideia, sentidos e sentimentos. Para Aristóteles (385-322 a. C.), a percepção percorre os sentidos: visão, audição, olfato, paladar e tato. A percepção sensível está articulada aos objetos sensíveis e as partes do corpo capazes de percebê-los. É uma operação dinâmica articulada que não precisaria recorrer ao pensamento: "os sentidos podem, inclusive, perceber que percebem" (SAES, 2010, 11-4).

Para alguns filósofos modernos, a percepção é uma representação de pensamentos e ideias, neste sentido, passa por processos racionais. Em Descartes (1596-1650), a percepção é um ato intelectual. Em Hume (1711-1776) a percepção é ampliada em duas categorias: impressões, que são mais fortes e vividas e pensamentos ou ideias, que são percepções mais tênues. São gradações interdependentes, pois, "as ideias dependem das impressões para existir" (SAES, 2010, p. 20).

Na filosofia de Kant (1724-1804): "as coisas que existem na realidade e que podem ser objetos da nossa experiência somente aparecem para nós como fenômenos, nunca como coisas-em-si. Assim, o que podemos legitimamente perceber são fenômenos" (SAES, 2010, p. 23). A percepção pelos fenômenos se dá pela consciência das sensações que são apreendidas pela intuição empírica de um objeto representado como real no tempo e espaço (SAES, 2010, 25).

Os estudos mais contemporâneos sobre percepção encontraram na fenomenologia um campo fecundo de reflexões e de desenvolvimento. Para Cerbone (2013, p.13) que estudou os principais filósofos da fenomenologia - Husserl, Heidegger, Sartre e MerleauPonty - a palavra fenomenologia significa: "o estudo dos fenômenos, onde a noção de um fenômeno e a noção de experiência, de um modo geral, coincidem. Portanto, prestar atenção à experiência em vez de àquilo que é experienciado é prestar atenção aos fenômenos".

Apesar dos autores acima citados serem identificados como fenomenólogos, cada um deles deixou uma marca própria na filosofia dos fenômenos. Vou discutir algumas ideias de Maurice Merleau-Ponty (1908-1961), em seu livro Fenomenologia da Percepção pelo fato do autor ser uma das bases teóricas de Tim Ingold um dos autores aqui adotado por analisar a percepção ambiental. 
Merleau-Ponty parte de uma crítica de posições dualistas como mente-corpo e sujeitoobjeto. Para Merleau-Ponty (1999, p. 1-2) a fenomenologia é "o estudo das essências", de todas elas: essência da percepção, da consciência... Mas também: "uma filosofia que repõe as essências na existência". É transcendental e ao mesmo tempo "um relato do espaço, do tempo, do mundo "vivido"'. O autor rompe com o causalismo, o empirismo e o intelectualismo moderno, pois, para ele a fenomenologia: "é a tentativa de uma descrição direta de nossa experiência tal como ela é, e sem nenhuma deferência à sua gênese psicológica e às explicações causais que o cientista, o historiador ou o sociólogo dela possam fornecer".

"O mundo é aquilo que nós percebemos". Mas também, "o mundo é não aquilo que eu penso, mas aquilo que eu vivo; eu estou aberto ao mundo, comunico-me indubitavelmente com ele, mas não o possuo, ele é inesgotável" (MERLEAU-PONTY, 1999, p.14). Ele constrói sua teoria da percepção de base fenomenológica a partir de críticas ao empirismo ${ }^{58}$ e ao intelectualimo ${ }^{59}$, que ele chama de prejuízos clássicos. A partir daí propõe a ideia de retornar aos fenômenos, redespertando e redescobrindo a experiência perceptual. O autor procura restituir a percepção no seu sentido originário. Esta operação passa pela corporificação da própria experiência do ser. A nossa existência está interconectada a consciência, a corporificação e ao mundo manifesto através de nossa experiência perceptiva:

A vida da consciência - vida cognoscente, vida do desejo ou vida perceptiva - é sustentada por um "arco intencional" que projeta em torno de nós nosso passado, nosso futuro, nosso meio humano, nossa situação física, nossa situação ideológica, nossa situação moral, ou antes que faz com que estejamos situados sob todos esses aspectos. É este arco intencional que faz a unidade entre os sentidos, a unidade entre os sentidos e a inteligência, a unidade entre a sensibilidade e a motricidade (MERLEAU-PONTY, 1999, p.190).

Ingold (2000, p. 168-71) ao revisitar a fenomenologia de Merleau-Ponty coloca em perspectiva as superações das dicotomias entre biologia e cultura; mente e corpo, pois, para ele, isso tudo faz parte do mesmo processo de pensar, de perceber, de lembrar e de aprender no contexto ecológico das interrelações das pessoas com seu meio ambiente.

\footnotetext{
${ }^{58}$ Segundo Cerbone (2013, p. 173): "a descrição empirista da percepção, como recepção de estímulos e posse de sensações, converte a experiência em algo completamente passivo e inerte: uma série de eventos que surgem de um modo causal, quase mecânico. (...) Na verdade, o empirismo parece negligenciar inteiramente o fato de que a experiência perceptual é vivida por alguém que percebe. Nas palavras de Merleau-Ponty (1999, p.26): "construímos a percepção com o percebido".

${ }^{59}$ O intelectualismo trata a percepção como um ato mental do juízo. Segundo Merleau-Ponty (1999, p.60): "o intelectualismo vive da refutação do empirismo e nele o juízo tem frequentemente a função de anular a dispersão possível das sensações".
} 
Ingold (2000, p. 139) ao analisar a relação entre a terra e a memória ${ }^{60}$, concebe a terra como um campo de moradia para seres de todo tipo: humanos e não-humanos geneticamente inspirados por uma concepção de diversidade biocultural. Habitar a terra é constituir um lugar como um locus de crescimento pessoal e de desenvolvimento em que cada lugar forma o centro de uma esfera de nutrição (INGOLD, 2000, p. 149). Neste modelo relacional, Ingold concorda com a ideia de J. Leach, em que "parentesco é geografia", então "as vidas das pessoas e a história das suas relações podem ser traçadas nas texturas da terra" (INGOLD, 2000, p. 150). Nesta perspectiva, as relações das pessoas derivam da sua identidade e pertencimento à terra, elementos que caracterizam os povos indígenas e podem servir de inspiração:

\begin{abstract}
Indigenous people regard all products of the human mind and heart as interrelated, and as folowing from the same source: the relationships between the people and their land, their kinship with the other living creatures that share the land, and with the spirit world. Since the ultimate source of knowledge and creativity is the land itself, all of the art and science of a specific people are manifestations of the same underlying relationships, and can be considered as manifestations of the people as a whole (INGOLD, 2000, p. 150).
\end{abstract}

A percepção do meio ambiente também é uma construção cultural da natureza. Sobre o conceito de meio ambiente, Ingold (2000, p. 20) tem a seguinte posição: 1) meio ambiente é um termo relativo. Não pode existir um organismo sem meio ambiente, nem meio ambiente sem organismo. Seria algo como: eu sou o meio ambiente, o meio ambiente sou eu; 2) o meio ambiente nunca está completo, está sempre em construção; 3) não se deve confundir o meio ambiente com a natureza.

Steil e Carvalho (2012, p. 11) em obra que analisa a dimensão ecológica no pensamento de Ingold situam o seu pensamento sobre o ser humano como o de: "um ser imerso no fluxo da vida e dependente dos processos e movimentos dos materiais que constituem nossos corpos e nossas mentes, com os quais traçamos as linhas de nossa história natural e cultural". Para os autores, nesta interpretação, Ingold:

\begin{abstract}
leva a sério o pertencimento de todos os seres que habitam o mundo à trama da vida, ele retira o caráter de externalidade dos seres humanos em relação ao mundo, ao mesmo tempo em que o apresenta como um ser menos potente para controlar os destinos do planeta e mais partícipe das linhas de vida que o atravessam, constituem e ultrapassam (STEIL, CARVALHO, 2012, p. 11).
\end{abstract}

\footnotetext{
60 "Land and history, in short, figure as mutually exclusive alternatives. For indigenous people themselves, by contrast, it is in their relationships with the land, in the very business of dwelling, that their history unfolds. Both the land and the living beings who inhabit it are caught up in the same, ongoing historical process" (INGOLD, 2000, p. 139).
} 
A prática do oguatá dos kaiowá-guarani simboliza uma percepção através do movimento do caminhar. Como coloca Ingold ${ }^{61}$ (2011), o mundo é percebido através dos pés e a locomoção é a porta de entrada para a nossa percepção do mundo. Ele argumenta que a noção de espaço é abstrata, vazia e distante da realidade da vida e da experiência. Enquanto que a ideia de lugar é definida pelo movimento onde as pessoas habitam. Ao refletir sobre um trabalho de campo do povo Evenki na Sibéria ${ }^{62}$ acerca da localização das suas terras originais por David Anderson, constatou-se que no passado as pessoas viajavam e viviam não em qualquer lugar, mas em todo lugar. Contudo esse "todo lugar" não é "lugar nenhum". Eles habitavam a terra ao longo de caminhos que os conduziam de um lugar a outro lugar através do movimento. Esta análise parece ser bastante esclarecedora e se aproxima da filosofia do caminhar, da andança, do oguatá dos kaiowá-guarani.

Esta reflexão sobre o "lugar" e suas inúmeras possibilidades de percepções, inclusive como algo ideal construído coletivamente por uma cultura faz pensar no profetismo tupiguarani da Terra sem Mal, que nas palavras de Clastres (2007, p. 38) é um lugar "privilegiado, indestrutível, em que a terra produz por si mesma os seus frutos e não há morte", situado às vezes a leste, outras a oeste, para onde iriam as almas dos mortos, mas também, os vivos. Danças, festas e bebidas seriam as regras existentes em um lugar inicialmente descrito como de abundância: "o milho cresce sozinho, as flechas alcançam espontaneamente a caça...Opulência e lazeres infinitos" (Idem, p. 85).

O lugar constitue os territórios existenciais, vistos como uma "construcción eco-cultural del território-región" (ESCOBAR, 1999, p. 271). Neste sentido, "o lugar é central no tema do desenvolvimento, da cultura e do meio ambiente, e é igualmente essencial, por outro lado, para imaginar outros contextos, para pensar acerca da construção da política, do conhecimento e da identidade" (ESCOBAR, 2005, p. 11).

A fenomenologia de pertencimento a um lugar se relaciona com o que o geógrafo humanista Yi-Fu Tuan, em sua obra seminal chama de topofilia, ou seja, "o elo afetivo entre a pessoa e o lugar ou ambiente físico" (TUAN, 2012, p. 19). Os laços afetivos do ser humano para com o meio ambiente podem se expressar de diferentes formas: estética, tátil ou sentimentalmente. A primeira pode ser sentida, por exemplo, através da beleza paisagística de um determinado lugar, como uma praia, uma montanha ou uma floresta.

\footnotetext{
61 "But if perception is thus a function of movement, then what we perceive must, at least in part, depend on how we move. Locomotion, not cognition, must be the starting point for the study of perceptual activity. Or more strictly, cognition should not be set off from locomotion, along the lines of a division between head and heels, since walking is itself a form of circumambulatory knowing" (INGOLD, 2011, p. 46).

62 "Evenki herders did not formerly live in space rather than place. The illusion that they did is a product of our own cartographic conventions that lead us to imagine the surface of the earth divided into a mosaic of areas, each occupied by a named nation or ethnic group. On a map drawn according to these conventions, the few thousand Evenki appear to occupy an area almost twice the size of Europe! The Evenki people, however, did not occupy their country, they inhabited it. And whereas occupation is areal, habitation is lineal" (INGOLD, 2011, p. 149).
} 
Revela o prazer em se estar em um lugar que desperta ou evoca sensações de prazer estético.

O contato físico ou tátil apresenta muitas nuances, mas uma delas pode ser descrita pelo contato profundo com a terra. Tuan cita a relação do trabalhador rural com a natureza, em que esta formaria parte dele, o personificando. Para o autor: "esse sentimento de fusão com a natureza não é simples metáfora. Os músculos e as cicatrizes testemunham a intimidade física, da dependência material e do fato de que a terra é um repositório de lembranças e mantém a esperança" (TUAN, 2012, p. 141). O que não significa dizer que devido a esta proximidade ou personificação não ocorram sentimentos ambivalentes como os de amor e ódio a depender das condições ambientais existentes no espaço e no tempo.

Já os sentimentos associados com o lugar podem gerar imagens e estímulos sensoriais potencialmente infinitos. Para Tuan (2012, p. 161): "aquilo em que decidimos prestar atenção (valorizar ou amar) é um acidente do temperamento individual, do propósito e das forças culturais que atuam em determinada época". Há lugares que despertam "sentimentos topofílicos". Para o autor: "o meio ambiente pode não ser a causa direta da topofilia, mas oferece o estímulo sensorial que, ao agir como imagem percebida, dá forma às nossas alegrias e ideais" (Idem).

Para Eric Dardel, na sua também geografia humanista, há uma reflexão sobre a ligação do homem com a Terra em uma perspectiva mítica. Para o autor, a Terra é: origem, nutrição, regeneração e fonte de vida, onde: "vir ao mundo é se destacar da terra, mas sem romper jamais, inteiramente, com o cordão umbilical pelo qual a terra nutre o homem" (DARDEL, 2015, p. 48). A origem mítica da Terra é uma presença contínua, em que:

o mito não é de forma alguma a narrativa de um acontecimento ocorrido em uma data precisa e única. Ele é absoluto, isento do tempo como data ou momento. Essencial, ele engloba todos os existentes. Essa "essência", realidade típica e exemplar, os diversos seres a atualizam, a repetem e a manifestam (Idem, p. 51).

Dardel afirma o poder telúrico da terra que não se limita a superfície visível das coisas. Há um lado da terra que está sempre pronto a se manifestar: a dimensão do sagrado, que caminha junto com a estética e a capacidade de contemplação. Para o autor: "habitar a Terra, percorrê-la, plantar ou construir é tratá-la como um poder que deve ser honrado: cada um de seus atos é uma celebração, um reconhecimento do laço sagrado que une o homem aos seres da Terra, das águas ou do ar" (Idem, p. 54).

No sentido etimológico, a Terra deve ser "contemplada". Consequentemente, geografia e cosmologia seriam a mesma coisa. Dardel é enfático: "nenhum fato pode refutar jamais a interpretação mítica, porque só o que é garantido pelo mito se torna verdadeiramente real" (Idem, p. 54). A realidade do mito é vivida pelos sujeitos coletivamente através da vida diária e fortalecida em alguns momentos, como cerimônias e 
festas. Dardel coloca que a geografia não pode afastar-se do mito, pois, "o mito, sempre colocado sobre as coisas, para as fundar, é precisamente o que faz a realidade aparecer como realidade, e a realidade confirma a todo momento o "fundamento" mítico" (Idem, p. $65)$.

Mitos e memórias através das paisagens constituídas por árvores, águas e rochas no ocidente compõem o livro de história e arte ambiental de Schama (1996), onde considera que os velhos mitos da natureza nunca desapareceram, embora nem todas as culturas abracem a natureza com igual ardor e possuam suas fases de maior e menor entusiasmo. $O$ autor reconhece a importância da complexidade de mitos, metáforas e alegorias da natureza para a constituição da memória em um mundo movido a máquinas, cuja inventividade constitui nossa tragédia, uma vez que o domínio da natureza parece ser nossa marca registrada, podendo levar a nossa destruição (Idem, p. 24-5).

O sentido de pertencimento a um lugar constitui um elemento importante para a construção do movimento de ecocrítica ${ }^{63}$ na literatura, como mostra Heffes (2013) ao percorrer diversos textos e representações artísticas do que ela chama de "políticas da destruição e poéticas da preservação" do meio ambiente na América Latina. O pertencimento mostra a nossa relação com um lugar específico, determinando nossas formas de ser e atuar que está representada de diversas formas na literatura (Idem, p. 29).

Speller (2005, p. 133) faz uma ampla revisão de literatura sobre o tema da vinculação da pessoa ao lugar com base em processos cognitivos, afetivos e comportamentais. Sua argumentação se baseia em três conceitos centrais: a) identidade de lugar; b) vinculação ao lugar e c) tempo e lugar. A ideia de lugar tem sido trabalhada por diferentes perspectivas desde muito tempo. Aristóteles já invocava o lugar através de uma dimensão proveniente da relação entre a pessoa e o ambiente físico pelos sentimentos de pertença.

A construção da identidade de lugar é um processo dinâmico que pode ser percebido através dos espaços de pertencimento e de vivência cujos vínculos cognitivos e emocionais traduzem significados para indivíduos ou grupos sociais. Neste sentido, poderia dizer que a identidade étnica se relaciona com a identidade de lugar. Como pontuam Mourão e Cavalcante (2011, p. 212), "a função primária do lugar é a de gerar um senso de pertencimento e de conexão".

Para Elali e Feijó de Medeiros (2011, p. 55), a vinculação ao lugar possui muitas dimensões, dentre as quais se destacam: a dimensão funcional, que se refere ao papel desempenhado pelo espaço físico; a dimensão simbólica, em que a memória de lugares

\footnotetext{
63 "La ecocrítica consiste en el estudio de la literatura y el medio ambiente a través de un espíritu de compromiso con la práctica ambiental". O temo foi possivelmente cunhado em 1978 por William Rueckert em um ensaio chamado "Literature and Ecology: an experiment in ecocriticism". (HEFFES, 2013, p. 29-30).
} 
experenciados constitui uma fonte importante de estudos e a dimensão relacional, referente às interações entre pessoas e espaços.

A vinculação ao lugar pode estar associada ao que Escobar (1999) chama de defesa do lugar. A defesa é feita pelos povos para a manutenção do seu modo de se relacionar com a natureza/cultura. O autor, ao analisar a defesa do lugar, realizada pelos movimentos sociais com ênfase na população das florestas tropicais, verificou que esta se baseia em quatro direitos fundamentais: a identidade, o território, a autonomia política e a visão própria de desenvolvimento" (ESCOBAR, 2005, p. 12-3).

O tempo é um elemento imprescindível para a constituição de lugares, com seus vínculos, afetos e significados e, de experiências ambientais. A memória reforça positiva ou negativamente as lembranças vividas em um lugar. De modo que o passado ambiental de indivíduos ou grupos contribui para a constituição da vinculação ao lugar.

O lugar pode possui um viés individual e/ou coletivo que perpassa uma linha do tempo entre passado, presente e futuro. E, dependendo da formação e orientação do pesquisador, são destacados elementos físicos, sociais, culturais, comportamentais, espirituais, telúricos, poéticos, dentre outros, relativos ao lugar. Um lugar também pode ser o que Tuan (2013, p. 240) chamou de "uma pausa no tempo", baseado em aportes da fenomenologia e do existencialismo, para situar a experiência humana com o lugar. Os pontos principais do seu pensamento são:

1) Se o tempo for concebido como fluxo ou movimento, então lugar é pausa. De acordo com esse enfoque, o tempo humano está marcado por etapas, assim como o movimento do homem no espaço está marcado por pausas. Do mesmo modo como o tempo pode ser representado por uma flecha, uma órbita circular ou caminho de um pêndulo oscilante, assim também os movimentos no espaço; e cada representação tem seu conjunto característico de pausas ou lugares. 2) Leva-se tempo para se sentir afeição por um lugar, a qualidade e a intensidade da experiência é mais importante do que a simples duração. 3) Estar arraigado em um lugar é uma experiência diferente da de ter e cultivar um "sentido de lugar".

Experienciar um lugar passa pelo racional, mas também pelos sentidos (tato, paladar, olfato, audição e visão) e pelos sentimentos. Metáforas, gestos e falas kaiowá como: "comer a terra", "terra não me pertence, eu é que pertenço a terra", "eu sou a terra", "a cor da terra é a cor da pele" revelam muito do pertencer à terra. Há um sentimento étnico coletivo de pertencer à terra que perpassa a flecha do tempo. Pertencer à terra é diferente de dominar, ter ou apropriar-se da terra.

A ideia de sacralidade e de pertencimento à terra aparece no famoso discurso de Seattle, cacique dos Duwamish, em 1856, como resposta ao então governador do território de Washington, Isaac Stevens, sobre o seu intuito de comprar a terra dos indígenas. A íntegra do discurso pode ser encontrada em Boff (1999a, p. 335-41), do qual destacarei alguns trechos que se relacionam mais diretamente com os temas aqui tratados. $O$ cacique 
questiona: "Como podes comprar ou vender o céu e o calor da Terra?" Ele contrapõe a ideia do branco, que não compreende o modo de viver dos Duwamish, ressaltando a sacralidade da natureza: "Cada torrão desta terra é sagrado para o meu povo". A interdependência de todos os seres está evidente nesta passagem: "Se todos os animais se acabassem, o homem morreria de solidão de espírito. Porque tudo o que acontece aos animais, logo acontece também ao homem. Tudo está relacionado entre si”. E sobre o forte vínculo de pertencimento:

De uma coisa sabemos: a Terra não pertence ao homem. É o homem que pertence à Terra. Disto temos certeza. Todas as coisas estão interligadas como o sangue que une uma família. Tudo está relacionado entre si. O que fere a Terra fere também os filhos e filhas da Terra. Não foi o homem que teceu a trama da vida: ele é meramente um fio da mesma. Tudo o que fizer à trama, a si mesmo fará (BOFF, 1999a, p.339).

A Terra tem uma dimensão material e terrenal da existência em que pertencemos a ela, viemos dela e somos ela. Pertencer a terra é senti-la e conhecê-la como unidade, no sentido de que o homem é mais um dos seres que habita a terra e não o seu dominador. Pertencer é ser e não ter, a ideia de que não é a terra que pertence ao homem e sim o homem à terra se aproxima mais das éticas não-antropocêntricas. Ser Terra significa que: "temos elementos-Terra no corpo, no sangue, no coração, na mente e no espírito" (BOFF, 2012b, p. 85).

A relação de pertença é ontológica, existencial e recíproca. Por isso, a transformação da terra e dos seus "recursos" em mercadorias é incompatível com o vínculo de pertencimento étnico, que é passado de geração em geração pela oralidade como principal sistema de aprendizagem e de sensibilidades. Pertencer a uma terra por nascimento ou opção possui vários sentidos individual e coletivo de ordem: social, política, econômica, espiritual... Mas, "a relação de pertença resultante pode ser caracterizada como uma relação de intimidade ou de inerência. A terra está envolvida na constituição de um povo. Caracteriza-o, tal como ele a caracteriza" (WHITT, 2003, p. 21). A terra é o local do conhecimento. Conforme Whitt, 2003, p. 29:

Narrar histórias é uma forma de conversação com o mundo natural, parte da maneira como as coisas chegam a ser conhecidas. Transmite importantes informações sobre a natureza desse mundo, dos seus seres e dos seus processos. As histórias são um meio de relacionar conhecimento e de correlacionar comportamentos. Mostram como "os do passado" estão ligados à terra, aos do presente e aos "ainda não nascidos", e como os do presente se devem comportar à luz destes factos.

A relação de pertença é reafirmada pelos laços genealógicos, gerando vínculos de filiação e morais entre gerações. "Como tal, ela persiste, não cessa como resultado de "remoções" nem termina com a morte. Os seres individuais estão situados no interior de uma família, no interior de uma geração e no interior de uma terra cheia de outros seres, humanos e não humanos" (Idem, p. 22). 
Pertencer é não estar preso. É ter liberdade para desenvolver potencialidades em perspectiva individual e coletiva em um lugar. O que para os kaiowá-guarani, em condições ideais, se revelaria pela mobilidade de habitar, de praticar agricultura, de caminhar, de viver conforme a tradição, no teko, no modo de ser através dos vínculos afetivos e espirituais com a terra.

Pertencer à terra também implica em responsabilidades e cuidados na sua conservação. "Cortar esses vínculos é cortar o conhecimento neles embebido e abandonar o seu papel no desempenho das responsabilidades que cada um tem como guardião dessa porção do mundo natural. É alienar, se não for destruir, todo um sistema de conhecimento e de valores" (Idem, p. 30).

Devido ao forte vínculo de pertença, por mais destruído que se encontre um lugar as pessoas a ela vinculadas não cortam a sua ligação com ela. São precisas as palavras de Whitt (2003, p. 25): "Por mais profanado que esteja um lugar, as responsabilidades de custódia do povo permanecem. Não importa quanto possa estar estragada, a terra conserva o seu poder e o seu significado". O importante nessa relação de pertencimento é que sejam mantidos seus guardiões, pois, "o estado de uma terra que perdeu os seus guardiões, e de um povo que perdeu a sua terra, são comparáveis: abandono e desterro" (Idem, p. 25).

\subsubsection{Terra: resistência pela diversidade}

Existem singularidades no território brasileiro que o colocam em uma posição de destaque face ao cenário internacional quanto à riqueza de diversidade natural. Como destaca Pádua (2009), o fato de compormos "um país e seis biomas" faz o Brasil liderar a lista dos países mais megabiodiversos do mundo. Os biomas: amazônia, mata atlântica, caatinga, cerrado, pantanal e pampa, constituem mosaicos de ecossistemas. O bioma é um conceito que "unifica um conjunto de ecossistemas que tem identidade física e ecológica" (PÁDUA, 2009, p. 122).

Em instigante ensaio sobre a biodiversidade brasileira, Drummond (2014, p. 66) defende que: "a biodiversidade é um patrimônio integralmente natural construído pelo processo evolutivo, e cujo valor maior reside nela mesma". Para ele, os humanos necessitam e modificam a biodiversidade, mas não a criam, nem a recuperam. Há uma distinção entre a biodiversidade natural (selvagem, nativa ou in situ) e a biodiversidade construída ou modificada pelos humanos, como a agrobiodiversidade (agropecuária, jardins, hortas, viveiros, florestas plantadas, jardins botânico, zoológico etc).

A biodiversidade natural além de ser biologicamente mais rica é também mais difícil de proteger. Já a "agricultura e pecuária são operações culturais que, por definição, modificam, simplificam e empobrecem a biodiversidade nativa" (Idem, p. 90). A biodiversidade natural é 
pouco conhecida em termos científicos, principalmente, em se tratando de biomas e ecossistemas dos trópicos. Também não há uma valoração social hegemônica do seu papel para a vida no planeta e por ser um patrimônio difuso, muitas vezes não há sentimento de pertença e normas para efetivamente protegê-la. Diferentemente dos sistemas agropecuários, que são melhor protegidos, pois, social e economicamente possuem uma valoração positiva, dispõem de conhecimentos científicos, tecnologias, práticas, normas jurídicas, sistemas de propriedade e políticas públicas que melhor os protegem.

Com base nas provocativas perguntas de Drummond (2014, p. 103): quem já ouviu falar que a soja, a cana-de açúcar ou os bois estivessem em perigo de extinção? Principalmente, em um estado como o Mato Grosso do Sul onde demograficamente há mais cabeças de gado do que de seres humanos. No entanto, a rica confluência de três biomas: mata atlântica, cerrado e pantanal, que o tornam singular, está em acelerado processo de destruição. E, em particular, no sul do estado, embora, não existam estudos mais avançados sobre a perda de biodiversidade (daí mais um dos elementos que dificultam a proteção!), percebeu-se através dos estudos etnográficos e do trabalho de campo um amplo processo de transformação das paisagens naturais, de perda e diminuição de espécies animais e vegetais e de degradação do solo e dos corpos hídricos.

Por mais óbvio que possa parecer, estamos de olhos fechados para ver como alerta Drummond (2014, p. 125) que: "qualquer país pode plantar soja e criar bois. Nenhum país pode, como o Brasil, combinar em seu próprio território tanta agricultura e pecuária com a proteção e o conhecimento de uma biodiversidade natural tão rica". A condição de país megadiverso, que também constitui a nossa identidade, deveria, como aponta Drummond (Idem), colocar o Brasil como "guardião" desse patrimônio natural e diverso. Nesse papel, devem ser combinados usos moderados da biodiversidade, estudos científicos da biodiversidade e esforços de recuperação de áreas degradadas.

Os projetos de recuperação de áreas degradadas, de restauração ecológica ou de reflorestamento enfrentam dificuldades de diversos níveis, tais como: o conhecimento das espécies que ocupavam a área; a sua reprodução e transplante e a sua adaptação em um ambiente profundamente modificado, muitas vezes ocupado com espécies invasoras e exóticas. São recentes as experiências de restauração de ecossistemas nativos no Brasil. A transformação de espaços degradados exige décadas, conhecimento científico, recursos financeiros e cuidado humano e, mesmo assim, as chamadas florestas secundárias são mais pobres em termos de biodiversidade do que as florestas primárias ou nativas. 
Para Pádua (2009, p. 135), "a ecologia de restauração será uma marca do século XXI". A ecologia da restauração insere-se no contexto da biologia da conservação ${ }^{64}$, ciência interdisciplinar que busca responder a crise ambiental resultante do efeito das atividades humanas sobre os ecossistemas e restaurar processos ecológicos essenciais. Conforme a definição da Society for Ecological Restoration, é "o processo de alterar intencionalmente um local para restabelecer um ecossistema que ocupava aquele local originalmente. $O$ objetivo deste processo é copiar a estrutura, o funcionamento, a diversidade e a dinâmica de ecossistemas específicos" (PRIMACK, RODRIGUES, 2001, p. 251).

Existem alguns princípios gerais que orientam a ecologia da restauração: a) nenhuma ação, deixar a área se recuperar por si mesma; b) substituição de um sistema degradado por outro tipo de ecossistema produtivo; c) reabilitação para recuperar algumas das funções do ecossistema e algumas espécies; d) restauração da área com base na sua composição original (Idem, p. 255-6).

Mas seria possível restaurar a biodiversidade? Depreende-se da fala de muitos dos meus interlocutores, principalmente, dos mais velhos e dos rezadores e, de algumas interpretações da cosmologia kaiowá-guarani que não. Os animais e as plantas estão escondidos debaixo da terra por causa das perturbações humanas no equilíbrio da terra. Eles voltarão, mas é preciso deixar a terra quieta para que o mato volte a crescer e com ele todos os seus seres. Conforme Brand (1997, p. 210):

Nas discussões em torno desta problemática específica emergiu claramente
que os Kaiowá/guarani seguem movimentando-se dentro dos mesmos
princípios orientadores próprios da agricultura tradicional, segundo os quais
a mata é algo que se recupera por força da natureza, ou melhor, por força
da prática das rezas. Por isso mesmo não há que se preocupar em
replantar árvores.

No entanto, Brand, foi coordenador de um exitoso projeto de recuperação ambiental em Te'ýikue (tema aprofundado no capítulo 3) onde os conhecimentos tradicionais dos antigos, dos avós e dos pais foram dialogados com conhecimentos científicos para fazer a terra renascer. Nesta experiência, verificou-se a possibilidade de conduzir processos que induzissem a recuperação natural.

Existem leituras sobre biodiversidade que associam a diversidade cultural e os saberes tradicionais como elementos propulsores para a manutenção da biodiversidade. Há uma coincidência: onde há diversidade cultural e linguística também há diversidade

\footnotetext{
64 Para Primack e Rodrigues (2001, p. 9-10) os fundamentos da biologia da conservação consistem nos seguintes aspectos: a diversidade de organismos é positiva (condiz com o que Edward Wilson chamou de biofilia, ou seja, uma predisposição genética para gostar da diversidade biológica); a extinção prematura de populações e de espécies é negativa; a complexidade ecológica é positiva; a evolução é positiva e a diversidade biológica tem valor em si.
} 
biológica $^{65}$. Existe uma sobreposição entre a presença de povos com diversidade cultural em áreas ricas em termos de biodiversidade. Por isso, as estratégias de proteção de ambas devem caminhar juntas. Concordo com o axioma biocultural proposto pelo ecólogo mexicano Víctor M. Toledo (2003, p. 80), ao afirmar que: "la biodiversidad del mundo sólo será preservada efectivamente si se conserva la diversidad de las culturas y viceversa". Toledo (Idem) se baseia em algumas evidências:

el traslape geográfico entre la riqueza biológica y la diversidad lingüística y entre los territorios indígenas y las regiones de alto valor biológico (actuales y proyectadas), la reconocida importancia de los pueblos indígenas como principales pobladores y manejadores de hábitats bien conservados y la certificación de um comportamiento orientado al conservacionismo entre los pueblos indígenas, derivado de su complejo de creencias-conocimientospráticas, de carácter pre-moderno.

Existem vários pontos em comum entre os estudos sobre conservação ambiental e cosmologias indígenas. De um modo geral, são ressaltadas outras dimensões, para além da econômica, na relação com a terra. Dimensões do sagrado, de respeito e de veneração são trazidas por Toledo (2003, p. 77 ) ao se referir aos povos indígenas que:

No consideran a la tierra meramente como un recurso económico. Bajo sus cosmovisiones, la naturaleza es la fuente primaria de la vida que nutre, sostiene y enseña. La naturaleza es, por lo tanto, no sólo una fuente productiva sino el centro del universo, el núcleo de la cultura y el origen de la identidad étnica. En el corazón de este profundo lazo está la percepción de que todas las cosas vivas y no vivas y los mundos social y natural están intrínsecamente ligados (principio de reciprocidade).

A sabedoria ecológica dos povos indígenas se revela através da relação do que pode ser nomeado como biodiversidade nativa, ou seja, biomas, ecossistemas e florestas naturais e, também agricultura, em que prevalece a diversidade de sementes e de alimentos.

As práticas de agricultura exercidas pelas famílias extensas kaiowá-guarani se aproximavam do que chamamos de sistemas agroflorestais e estavam baseadas em um profundo conhecimento da terra, o que se nomina, atualmente, de etnobotânica. Noelli ao tratar de antigas formas de assentamentos guarani (1993, p. 247-249, 251) descreve algumas características de manejo, como: a) plantio de diversas espécies de modo consorciado; b) respeito a processos ecológicos, como a vegetação sucessional natural para fazer as roças; c) plantio diversificado de espécies e descanso da terra após algumas colheitas com a rotação e o multiuso de plantas e espaços; d) desmatamentos seletivos, conservando-se algumas árvores; e) plantio em áreas de trilhas, clareiras, bordas de matas e locais alagadiços. O calendário agrícola acompanhava os momentos de festas e rituais. As roças eram feitas seguindo as fases de limpeza, derrubada e queima da mata. Nos diários

\footnotetext{
${ }^{65}$ A diversidade biológica existe em diversos níveis: a) no nível das espécies, incluindo todos os organismos da Terra; b) na variação genética dentre as espécies; c) nos ecossistemas, onde as espécies se encontram e realizam as interações (PRIMACK, RODRIGUES, 2001, p. 10).
} 
de campo de Eduardo Galvão de 1943, ele narra que "a roça na mata é melhor, porque não exige tanta limpeza. Em uma capoeira, a cada 10 ou 15 dias, há a necessidade de carpir, porque o mato rasteiro se desenvolve com muita facilidade. Na mata, apenas de mês em mês, há a necessidade de carpir" (GALVÃO, 1996, p. 204).

Neste contexto, é emblemática a relação das sociedades mesoamericanas com o milho. No México se diz que não se sabe se foi o homem que domesticou o milho ou se foi o milho que o domesticou. São chamados de "pueblos del maíz", cuja domesticação remonta a cerca de sete mil anos, com uma imensa variedade de espécies. Tamanha é a identificação nacional com a planta que Guillermo Bonfil Batalla escreveu: "sin maíz no hay país".

O milho tem uma dimensão sagrada, associado a "planta de los dioses", prevalecendo a visão de que o homem é formado a partir do milho. Um exemplo bem conhecido dessa noção se encontra na primeira parte do livro sagrado dos mayas conhecido como Popol $V_{u h}{ }^{66}$, que trata da descrição da criação do homem, após várias tentativas infrutíferas, foi, finalmente, feito do milho. De certo modo, o ciclo de vida do milho - que se inicia com a colocação da semente abaixo da terra até o seu crescimento rumo ao céu - é considerado uma metáfora do renascimento. Ampliando-se mais o seu significado, o mundo é concebido como um campo de quatro lados em que os deuses cultivavam o milho. Isto simboliza a estrutura do universo em que o milho constitui o eixo do mundo (VELA, 2011, p. 32).

O manejo tradicional do milho ocorre nas "milpas ${ }^{67 "}$ que segundo Toledo (2003, p. 114) é um espaço sagrado onde a natureza e o agricultor ajustam-se de modo flexível conforme a estabilidade e a resiliência dos ecossistemas. Manejar os recursos naturais significa: "comprender la dinámica cíclica de los sistemas ecológicos, sus diferentes capacidades para absorber el disturbio y lo impredecible y los ritmos y temporalidad de sus procesos" (Idem, p. 116). É o que se chama de manejo ajustável ("manejo que se ajusta" ou "adaptative management").

\footnotetext{
${ }^{66}$ Cito um trecho curto, mas muito significativo da criação do homem a partir do milho e do tzité (uma árvore, cujo grão vermelho é parecido com o do feijão). Os mayas usavam os grãos do milho e do tzité para fazer adivinhações e feitiçarias. "Echad la suerte con vuestros granos de maíz y de tzité. Hágase así y se sabrá y resultará si labraremos o tallaremos su boca y sus ojos en madera. Así les fue dicho a los adivinos. A continuación vino la advinación, la echada de la suerte con el maís y el tzité. -!Suerte! !Criatura!, les dijeron entonces una vieja y un viejo. Y este viejo era el de las suertes del tzité, el llamado Ixpiyacoc. Y la vieja era la adivina, la formadora, que se llamava Chiracán Ixmucané. Y comenzando la advinación, dijeron así: - !Juntaos, acoplaos! !Hablad, que os oigamos, decid, declarad si conviene que se junte la madera y que sea labrada por el Creador y el Formador, y si éste (el hombre de madera) es el que nos ha de sustentar y alimentar cuando aclare, cuando amanezca! Tú, maíz, tú, tzité; tú, suerte; tú, criatura: luníos, ayuntaos!, les dijeron al maíz, al tzité, a la suerte, a la criatura. !Ven a sacrificar aquí, Corazón del Cielo; no castigues a Tepeu y Gucumatz! (POPOL VUH, 1960, p. 29).

67 No manejo tradicional das milpas se pratica o sistema de "roza-tumba-quema" para promover uma regeneração ecológica e também procura-se manter uma diversidade de paisagens, espécies e variedades, "expresado en mosaicos espaciales, policultivos y germoplasmas poligénicos, la rotación espacial y temporal de prácticas, la creación de sistemas de carácter híbrido (agroforestales, agro-pecuarios, agropiscícolas y agrosilvopecuarios), y la manipulación integrada de procesos a diferentes escalas de tiempo y espacio" (TOLEDO, 2003, p. 114-5).
} 
Diferentemente, do que ocorre com os sistemas de agricultura monocultural, baseados em regime de propriedade privada onde produzem um rastro de destruição sobre os recursos naturais. Existem diferenças significativas entre as formas de cultivo e o grau de utilização dos recursos naturais entre sistemas monoculturais e a agricultura nativa. Segundo Shiva (2003, 56-8), nas monoculturas há o predomínio da "integração de sementes e os produtos químicos", visando tornar uma cultura "extremamente produtiva" e para isso são usadas "sementes, fertilizantes químicos, pesticidas, petróleo e irrigação intensiva e acurada", o que gera uma série de impactos ecológicos negativos. Na agricultura nativa prevalece uma "relação simbiótica entre solo, água, plantas e animais domésticos", em sistemas de "rotação de culturas" complexos e diversificados com insumos orgânicos (Idem).

Monoculturas geram uniformização; destruição e empobrecimento da natureza e da diversidade; concentração dos sistemas de produção e consumo; homogeneidade; dependência de insumos e vulnerabilidade ecológica. Esse modelo monocultural também atinge o pensamento e se expande para as práticas relacionais com o meio ambiente. Segundo Shiva (2003, p. 17):

\begin{abstract}
as monoculturas ocupam primeiro a mente e depois são transferidas para o solo. As monoculturas mentais geram modelos de produção que destroem a diversidade e legitimam a destruição como progresso, crescimento e melhoria. Segundo a perspectiva da mentalidade monocultural, a produtividade e as safras parecem aumentar quando a diversidade é eliminada e substituída pela uniformidade.
\end{abstract}

A imposição da uniformidade cultural gera instabilidade e vulnerabilidade natural e social. Mesmo devendo atender a uma função socioambiental (de acordo com a Constituição de 1988), o exercício da propriedade tem, histórica e prioritariamente, atendido a lógicas privatísticas, tendo levado a diversas situações de exclusão e injustiças sociais e ambientais. Por isso, o direito a terra (entendida esta como um ser vivo e com dinâmicas próprias) e o direito ao território (entendido com um viés étnico e de ocupação tradicional) devem auxiliar na construção de um diálogo mais harmônico entre os direitos indígenas, ambientais e econômicos.

A perda da diversidade biológica leva a perda da diversidade de saberes locais, resultando em um duplo empobrecimento: de natureza e de cultura. A ancestralidade do saber indígena no trato da terra tem sido subjugada em nome de um ideal universal de técnicas, políticas e economia que colonizam povos e ambientes.

Contudo, a ideia de resistência ${ }^{68}$ da Terra e dos povos do mato que vivem na sua terra formando, juntos, um mosaico de diversidade da vida, não é algo meramente passivo. As

\footnotetext{
${ }^{68}$ Por ocasião da pré-banca da presente tese, a professora Graciela Chamorro sugeriu a ideia de "persistência" ao invés de "resistência", pois, estaria associada a uma postura ativa, neste caso, mais condizente com a história dos kaiowá-guarani. No entanto, optei por manter o termo resistência e firmar o seu sentido como uma via de
} 
formas de resistência também adquirem um papel ativo diante da razão econômica hegemônica e devastadora de matas e de vidas. Leff (2014, p. 494) ao falar de histórias de lutas de resistência de povos em vários continentes, também as situa como estratégias de "reexistência" no caminho da sustentabilidade da vida. Uma resistência contra o extermínio cultural e a destruição ambiental para que a vida continue a existir. Nas suas palavras:

Las experiencias recientes de los movimientos socioambientales en América Latina, em Asia y em África, muestran no sólo la capacidad de la población local para resistir a la razón económica, instrumental y utilitarista hegemónica a través del cual el capitalismo penetra en sus territórios geográfico-socio-culturales de vida, sino también para crear visiones alternativas y nuevos caminos hacia la sustentabilidad desde sus racionalidades culturales, reinventando sus identidades, sus prácticas productivas y sus medios de vida (LEFF, 2014, p. 494).

A ideia de resistência se estende tanto para as culturas que possuem uma visão integral da Terra, pois, se sentem parte da mesma e se relacionam com seus elementos naturais com atividades de baixo impacto ambiental; quanto para as espécies ou seres nãohumanos. Esta ideia se coaduna com o pensamento de Wilson (2008, p. 25), quando afirma: "pode-se dizer que a humanidade alterou este planeta tão profundamente como permitem os nossos consideráveis poderes. E a despeito disso grande parte da Natureza resiste".

Os movimentos de resistência dos guarani remontam a época colonial e como interpreta Meliá (1988, p. 37), eles foram:

una afirmación de la identidad y una voluntad de autenticidad, permaneciendo en el modo de ser tradicional, específicamente religioso. La religión guaraní en este caso no es instrumentalizada en vistas a la liberación, sino que es la forma que da sentido al movimiento. Más que una reacción es una búsqueda.

Brand (1993, p. 78) situa a resistência dos kaiowá-guarani do seguinte modo: "resistem em torno de dois pontos básicos: a terra e o seu modo de ser". A dupla resistência de seres e saberes pode ser visualizada ao longo dos capítulos 3, 4 e 5 em que a força da tradição oral e da palavra constrói pontes para perpetuar os saberes sobre como ser na terra.

A resistência existe apesar das situações adversas nas terras indígenas regularizadas ou não. E prossegue mesmo diante da devastação das matas. Se poderia dizer que a resistência dos kaiowá-guarani nas terras em condições de acentuado processo de degradação decorre da presença da mata no seu ser interior ${ }^{69}$. A mata ou o mato estaria dentro deles. A resistência, com fortes conotações cosmológicas, somada a recuperação

mão dupla, em que ora se sobressaem atitudes passivas, ora ativas em relação aos mecanismos de luta política sobre as suas terras tradicionais. A resistência com esse duplo sentido também se estende a própria Terra como um ser vivo, originalmente, dotada de diversidade biológica.

${ }^{69}$ A ideia de floresta ou mata interior para pensar a fenomenologia dos kaiowá-guarani em relação à situação ecológica das suas terras tradicionais foi proposta por Graciela Chamorro por ocasião da realização da prébanca da presente tese. 
das terras tradicionais e a vivência do bom modo de ser faria com que a mata exterior se renove e os animais voltem a repovoar a terra. A força da espiritualidade e da palavra faria o caminho da expansão da mata interior dos kaiowá-guarani para a revitalização das matas biológicas.

Ao refletir sobre a ética da terra proposta por Boff creio ser possível fazer conexões entre a ecologia e mata interior dos kaiowá-guarani. Para Boff (1999) existe uma ecologia exterior e uma ecologia interior ou mental, em que o universo está dentro de nós. "As coisas todas estão em nós como imagens, símbolos e valores. O sol, a água, o caminho, as plantas e os animais vivem em nós como figuras carregadas de emoção e como arquétipos" (Idem, p. 37). E mais ainda:

A ecologia da mente procura recuperar o núcleo valorativo-emocional do ser humano em face da natureza. Procura desenvolver a capacidade de convivência, de escuta da mensagem que todos os seres lançam por sua presença, por sua relação no todo ambiental, a potencialidade de encantamento com 0 universo em sua complexidade, majestade $e$ grandeza. Ela procura reforçar as energias psíquicas positivas do ser humano para poder enfrentar com sucesso o peso da existência e as contradições de nossa cultura dualista, machista e consumista. Ela favorece o desenvolvimento da dimensão mágica e xamânica de nossa psique (Idem, p. 39).

Neste momento, gostaria de destacar alguns pontos referentes ao zapatismo, por sugestão da banca de avaliação da tese. Apesar do presente trabalho não ter como objetivo fazer estudos comparativos com os povos indígenas de outras partes, mas para valorizar a experiência vivida no período do doutorado no México, passo a trabalhar a ideia de que movimentos como o zapatista tem o mérito de apontar algo novo ${ }^{70}$ em diversos pontos de vista, passando pelo político, social e até mesmo poético. Ele constitui uma busca por respostas em um mundo dominado por processos de colonização, dominação, destruição e injustiças. Por isso, sinaliza lugares de esperança e demonstra que vale a pena lutar e resistir.

O movimento zapatista apesar de ter sua própria história, lógicas, colocações e processos revela que há valores universais que dialogam com questões de diversos povos nativos, originais ou indígenas de diversas partes do mundo. Valores como a reinvenção da democracia; o reforço às bases identitárias de poder; respeito à diversidade; proposições e novas formas políticas; autonomia e dignidade lançam perspectivas de esperança e de reencantamento do mundo.

\footnotetext{
${ }^{70}$ Para Díaz-Polanco (2011a, p. 171) o mérito dos zapatistas está baseado em duas coisas: "en su capacidad para enlazar las demandas de democracia, justicia y libertad que elllos enarbolaban, con la demanda indígena de autonomía, y en la tribuna nacional que construyeron para el debate de este tema, con lo que lograron que la reivindicación de los pueblos indios alcanzara una resonancia inusual. El vínculo resultó enormemente fecundo, y eficaz la apertura del espacio público".
} 
A ideia de diversidade natural e cultural numa perspectiva que supere dualismos dialoga com o a filosofia do movimento zapatista ${ }^{71}$ no México que propugna: "un mundo donde quepan todos los mundos". Um mundo onde unidade e diversidade formam a base de valores reivindicados pela democracia, justiça, liberdade e dignidade. O movimento foi um sopro de esperança, de imaginação e de resistência contra os processos de colonização, imperialismo e opressão verificados em séculos de história contra os povos indígenas na região. A originalidade e a criatividade do movimento reacendeu a chama do reencantamento do mundo através das possibilidades de transformações das terras e da diversidade nela existente.

Os processos de luta pela autonomia dos povos indígenas no México são inspiradores para outras áreas do mundo ${ }^{72}$. Foram muitas as fases de negociação em que se verificaram avanços e recuos entre as diversas fases de negociação e conversação nas esferas governamentais. O processo foi sendo construído paulatinamente entre os diversos povos, seus tradutores e governos. O México, por ser signatário da Convenção 169 da OIT possuía uma base normativa em que poderiam operar as mudanças constitucionais rumo a um novo modelo de federalismo. A construção de um pluralismo jurídico, de uma descentralização autêntica, de autogovernos e de uma lógica de poder heterônoma entre estado e povos indígenas constituíram as bases reivindicatórias do movimento que obteve alguns avanços e formalização de acordos.

\subsection{GAIA, PACHAMAMA E YVY}

\subsection{1 Ética e direito da natureza}

A Terra possuiu uma dimensão planetária no sistema solar e um tempo cósmico que ultrapassa em milhões de anos a existência humana. A dinâmica de composição das diversas formas de vida vem tecendo um intricado complexo de entes bióticos e abióticos formando possibilidades de coexistência na biosfera. Como lembra, um dos maiores estudiosos da biodiversidade, Edward O. Wilson (2012, p. 437):

\footnotetext{
${ }^{71}$ O ano de 1994 é tido como emblemático para vários atos do Exército Zapatista de Liberação Nacional (EZLN), em que várias cidades tiveram a sua influência como, San Cristóbal de las Casas, Las Margaritas, Altamirano e Ocosingo. A partir desse ano, o zapatismo teve muitas faces, como a militar/armada; civil e social. E suas projeções nos âmbitos nacional e internacional.

72 As novidades do movimento, segundo Díaz-Polanco (2011b, p. 234) foram que: "los alzados pertenecían a los núcleos indígenas de la región, estaban armados de un aliento moral y de un singular lenguaje que lograron fascinar a propios y extraños, y sus reivindicaciones eran una feliz combinación de reclamos nacionales y hondas aspiraciones de los pueblos originales. En buena medida por ello, el movimiento atrajo rápidamente simpatías dentro y fuera de México".
} 
a humanidade é parte da natureza, uma espécie que evoluiu ao lado de outras espécies. Quanto mais nos identificarmos com o restante da vida, mais rapidamente seremos capazes de descobrir as origens da sensibilidade humana e de adquirir o conhecimento sobre o qual fundamentar uma ética durável, um verdadeiro senso de direção.

As cosmologias ocidentais, andinas e dos kaiowá-guarani possuem teias de ligação, por isso, buscarei ressaltar canais de comunicação entre elas através da análise da percepção das diversas formas de vida na Terra, em particular, dos modos em que os seres humanos se relacionam com o que identificamos como natureza, meio ambiente e terra.

Gaia proveniente do termo grego simboliza a deusa da Terra $^{73}$ e, surgiu para Lovelock, em 1972 - o teórico que desenvolveu uma hipótese e, depois uma teoria, com a colaboração de Lynn Margulis - como uma metáfora para a Terra viva, termo sugerido pelo romancista William Golding ${ }^{74}$. No primeiro livro sobre o tema, Gaia foi definida como:

a complex entity envolving the Earth's biosphere, atmosphere, oceans, and soil; the totality constituting a feedback or cybernetic system which seeks an optimal physical and chemical environment for life on this planet. The maintenance of relatively constant conditions by active control may be conveniently described by the term 'homoeostasis' (LOVELOCK, 1997, p. 250).

A Terra vista como um sistema de vida autorregulável formado de componentes físicos, químicos, biológicos e humanos foi testado por Lovelock em 1981 através de um modelo matemático-computadorizado chamado de "Mundo das Margaridas" (Daisyworld) em que ele simulava o crescimento de uma planta escura e outra clara competindo em um planeta com o aumento progressivo da luz solar (LOVELOCK, 2006, p. 34). Esse modelo foi comprovado cientificamente e serviu de base não só para a biologia populacional, mas também para pensar o clima. Segundo Lovelock (2010, p. 169): "o que o fez especial foi que pela primeira vez o crescimento e a seleção de plantas foram rigidamente vinculados num modelo dinâmico com sua capacidade de afetar o clima e ser afetado por ele".

A ideia central é a de que a autorregulação da Terra tem como finalidade a manutenção da habitabilidade. Para isto, Gaia "resiste às nossas intervenções através de uma autorregulação, opondo-se ao modo como alteramos o ar com gases de efeito estufa e removemos sua cobertura natural de florestas para a lavoura" (LOVELOCK, 2006, p. 174-5). Em um mundo onde prevalece a lógica do crescimento e do desenvolvimento, a teoria Gaia - ciência holística da Terra - apresenta-se, nas palavras de Lovelock (2006, p. 130) como a

\footnotetext{
${ }^{73}$ A Terra constitui um dos mitos centrais para todas as culturas. Na cultura ocidental, a Terra pode ser para os gregos: Gaia, Deméter e Héstia e para os seus correspondentes latinos: Tellus, Ceres e Vesta. De acordo com Boff (2012b, p. 71): Gaia/Tellus é "a Grande Mãe, representava o planeta Terra como um todo vivo e produtor de vida". Deméter/Ceres, "representava a parte cultivada da terra. Aqui entra a colaboração humana com o trabalho e a arte do cultivo. Era a deusa das sementeiras". Héstia/Vesta "simbolizava aquela parte da terra que reservamos e delimitamos para construir o lar humano".

${ }_{74}$ "Gaia, às vezes, recebe o nome alternativo "Ge". Ge, obviamente, é o prefixo das ciências da geologia, geofísica e geoquímica. Para Golding, Gaia, a deusa que do caos criou a ordem, era um título adequado para a hipótese sobre um sistema Terra que regulava seu clima e química de modo a preservar a habitabilidade" (LOVELOCK, 2010, p. 189).
} 
base para um ambientalismo coerente e prático. Esta visão, se opõe a ideia de que a Terra é uma propriedade, um bem a ser explorado em benefício da humanidade. Para ele, "esta falsa crença de que somos donos da Terra, ou seus dirigentes, permite que nos declaremos a favor das políticas e programas ambientais, mas continuemos deixando as coisas como estão" (LOVELOCK, 2006, p.130).

A Terra como ser vivo tem suas eras geológicas, mas em termos históricos nunca a intervenção humana causou tanta intervenção nos ciclos de vida quanto nos séculos XX e XXI. A força destrutiva tem sido tão intensa e acelerada, que levou ao vencedor do Prêmio Nobel de Química (em 1995), o holandês Paul J. Crutzen, a nomear uma nova era geológica, chamando-a de era do Antropoceno. O termo foi criado em 2002 devido as fortes alterações do ser humano no planeta (MACHADO, 2014, p. 39). Daí pode-se dizer que geologicamente estamos no Holoceno, mas vivendo o Antropoceno.

A discussão sobre correntes de ética ambiental se desenvolveu a partir do reconhecimento de que existe uma crise ecológica que afeta de diversas maneiras a vida na Terra. Alguns a situam como uma crise de civilização ${ }^{75}$ em que seria necessário mudar o paradigma técnico-científico que tanto influencia os comportamentos socioeconômicos para promover as transformações que assegurem a vida no planeta.

Existem muitas concepções éticas sobre as relações entre seres humanos e natureza. Teoricamente, as abordagens estão divididas em dois grupos: antropocêntricas e nãoantropocêntricas. A ética antropocêntrica ${ }^{76}$ possui um viés utilitarista e coloca o ser humano numa posição de superioridade perante os demais seres da natureza. Esta é a posição hegemônica que guia a esfera econômica. Diferentemente das éticas não-antropocêntricas que defendem um valor intrínseco para a natureza independentemente dos interesses humanos. Neste campo, destacam-se: o biocentrismo, o ecocentrismo, a ecologia profunda (deep ecology) e o ecofeminismo.

Em linhas gerais, o biocentrismo atribui valor ético a todos os seres vivos, enquanto o ecocentrismo vai mais além, atribuindo valor a todas as entidades bióticas ou abióticas que compõem a biosfera. O ecocentrismo inspirou a filosofia da "ética da Terra" desenvolvida por Aldo Leopold entre as décadas de 1930-40.

Já ecologia profunda teve como precursor o norueguês Arne Naess, na década de 1970, tendo como base a ecosofia, que prega o direito à existência a todos os seres que compõem a vida na Terra, pois, são possuidores de valores intrínsecos. Os oito princípios

\footnotetext{
${ }^{75}$ Para Leff (2007, p. 9), a crise ambiental é uma crise civilizatória e de conhecimento: "la degradación ambiental es resultado de las formas de conocimiento a través de las cuales la humanidad ha construido el mundo y lo ha destruido por su pretensión de universalidad, generalidad y totalidad; por su objetivación y coisificación del mundo". Vide também: LEONARDOS, BILIBIO (2012a).

${ }^{76}$ Viola (1997, p. 58-9) alerta que na ética antropocêntrica podem ser depreendidas duas versões: uma extrema e outra moderada. A primeira visa à exploração e um expansionismo ilimitado (cowboy ethics). Já a moderada, admite a conservação ambiental com limites à exploração e ao crescimento material.
} 
básicos do movimento da ecologia profunda, cuja filosofia se baseia no valor inerente dos seres, na sua diversidade e na proteção das formas de vida influenciaram o desenvolvimento de teorias e práticas ecocêntricas. Conforme Moran (2008, p. 190): "um desmembramento do movimento de ecologia profunda é o ressurgimento do biorregionalismo, da ecologia de restauração e da agricultura com base local".

Outra corrente é o ecofeminismo, possuidora de várias linhas de debate e atuação sobre as relações mulher-natureza. A visão de mundo androcêntrica que domina a ciência, o saber e a cultura seria responsável pelo estado do mundo que ocasiona a crise ambiental. Por isso, a visão feminina de mundo seria importante para a efetivação de políticas ambientais.

Estas correntes de ética são as mais influentes no debate ambiental. Porém, delas se podem extrair vários desdobramentos e críticas. Destaco o posicionamento de François Ost que ao considerar tanto o dualismo quanto o monismo reducionistas, propõe uma mediação através da ideia de "retorno ao terceiro" através de um saber que seja realmente interdisciplinar. Para Ost (1995, p. 16):

A única maneira de fazer justiça a um (o homem) e a outra (a natureza), é afirmar simultaneamente a sua semelhança e a sua diferença. Se o homem é um ser vivo, ele tem também - o que é um privilégio exclusivo - a capacidade de liberdade e é gerador de sentidos, sujeito de uma história, autor e destinatário de regras. Se a natureza, no decorrer da sua evolução, produziu a espécie humana à qual assegura diariamente as condições de sobrevivência, ela é também, para o homem, "completamente diferente", absolutamente estranha. Homem e natureza têm um "vínculo", sem que, no entanto, se possam reduzir um ao outro.

A ideia de um caminho do meio e a referência a uma ética ambiental duradoura, também está presente na visão de Wilson, segundo o qual se deve superar as concepções filosóficas do antropocentrismo ou do biocentrismo, pois, o que importa é a conservação de espécies. Sua concepção ética dialoga com a prudência e considera cada elemento que compõe a biodiversidade como inestimável e insubstituível. Por isso, não se deve permitir que nenhuma espécie ou raça se extingua. Para ele, "há uma infinidade de indícios de que a perda da diversidade da vida põe em risco não apenas o corpo mas também o espírito" (WILSON, 2012, p. 441).

A perturbação ou a perda de biodiversidade leva a desestabilização do ambiente que sustenta as espécies e a diminuição dos serviços prestados pelos ecossistemas, o que pode ocasionar, nas suas palavras: estranheza e hostilidade (WILSON, 2012, p. 436). Esta situação pode levar a redução e extinção de espécies:

Estudos de campo mostram que, quando a biodiversidade é reduzida, também diminui a qualidade dos serviços prestados pelos ecossistemas. Estudos de ecossistemas sob estresse também demonstram que a degeneração pode ser imprevisivelmente abrupta. À medida que a extinção se espalha, algumas das formas desaparecidas revelam ter sido espécieschaves, cujo desaparecimento provoca o fim de outras espécies e tem um 
efeito multiplicador sobre a demografia das sobreviventes (WILSON, 2012, p. 436).

Destes estudos deve florescer a percepção e a ação do que ele chama de "uma era de restauração, recuperando a diversidade sublime da vida que ainda nos cerca" (WILSON, 2012, p. 441). Nas atuais condições ambientais que a Terra se encontra não basta impedir a destruição dos processos naturais, o que por si só já constitui um enorme desafio planetário, mas também atuar para a restauração dos ecossistemas, com o consequente repovoamento da diversidade de vida.

Mas o que é Natureza ${ }^{77}$ ? As tradições filosóficas apontam para inúmeros caminhos. As culturas indicam um arsenal de interpretações. Natureza e cultura ora se comunicam, até mesmo se fundem; ora se dicotomizam e se hostilizam.

Wilson, em um dos seus textos, coloca que: "a Natureza é aquela parte do ambiente original e de suas formas de vida que permanece depois do impacto humano. Natureza é tudo aquilo no planeta Terra que não necessita de nós e pode existir por si só" (WILSON, 2008, p. 23). Sua ideia reside na concepção de que o humano deve "ascender rumo à natureza, e não para longe dela" (WILSON, 2008, p. 188). O que consistiria em uma aliança pela vida e por suas diversas formas de manifestação.

Pierre Hadot (2006) no seu ensaio sobre a história da ideia de natureza articula mitologia grega com história da arte, tomando como ponto de partida o aforismo de Heráclito: "a natureza ama ocultar-se" e as noções de véu e desvelamento da deusa da Natureza, através de uma fusão entre Ártemis de Éfeso e Ísis egípcia. A partir daí constrói uma metáfora da revelação da natureza e das atitudes humanas com relação à natureza. $O$ enigma do segredo da natureza em Heráclito, segundo a interpretação de Hadot (2006, p. 335-6), significa que:

tudo que nasce tende a morrer, que a natureza é difícil de conhecer, que ela se encobre em formas sensíveis e mitos, que esconde em si mesma virtudes ocultas, mas também que o Ser está originalmente num estado de contração e de não-desdobramento, e, finalmente, com Heidegger, que o Ser desvela velando-se.

A representação de Ártemis/Ísis é a de uma figura feminina que tem na cabeça uma coroa e um véu, possui vários seios e na parte inferior do seu corpo há a figura de muitos animais. O véu que lhe cobre o rosto faz alusão ao véu da Natureza, que oculta segredos. Seu desvelamento mostra a possibilidade de revelação dos mistérios da Natureza. Há

\footnotetext{
77 Etmologicamente, conforme Pelizzoli (2002, p. 169): "a palavra Natureza vem do latim (nasci, nascor), e designa o nascer, crescer, ser criado; é uma visão processual da vida. Conhecer a Natureza é relacionar-se à sua gênese e a seu processo de nascer/crescer. A palavra grega evocada aí é Physis, significando a natureza como um todo, incluindo os aspectos humanos; daí a palavra "física", donde phy significa "germinar"'.
} 
inúmeras representações na arte ${ }^{78}$, como mostra Hadot (2006, p. 264), mas uma que parece emblemática é a de que o seu desvelamento leva ao triunfo do lluminismo e a construção de toda uma racionalidade científica que levou a dominação da natureza.

Partindo para a análise da Pachamama, numa perspectiva normativa, passo a discutir alguns aspectos referentes ao direito à natureza. Recentemente, a natureza adquiriu o status de um direito fundamental na pioneira Constituição do Equador, de 2008, ao incorporar no seu texto regras e princípios que reconhecem a natureza como sujeito de direitos. Este reconhecimento inaugura uma nova fase no constitucionalismo latinoamericano, pois, abala as estruturas tradicionais da teoria geral do direito ${ }^{79}$. A base do direito da natureza provém do direito à existência com um forte sentido de valor intrínseco e de comunidade da vida. Difere-se do direito ambiental, que é um direito humano, baseado em concepções antropocêntricas.

Do preâmbulo da Constituição de Montecristi, como é conhecida, destacam-se as partes referentes à celebração da natureza; a Pachamama, de que somos parte, sendo vital para a nossa existência e a busca de uma nova forma de convivência cidadã, na diversidade e harmonia com a natureza, para alcançar o buen vivir, o sumak kawsay (que na língua quéchua significa vida harmoniosa). $O$ artigo 71 traz expressamente a identificação da natureza com a Pachamama. $\mathrm{O}$ art. 72 dispõe sobre o direito da natureza a restauração e 0 art. 74 trata do buen vivir. Estes dispositivos que compõem o capítulo sétimo da Constituição esquatoriana podem ser vistos na íntegra através do Anexo.

Segundo Zaffaroni (2011, p. 112) a ideia de Pachamama tem uma origem andina significando: "una deidad protectora - no propiamente creadora, interesante diferencia cuyo nombre proviene de las lenguas originarias y significa Tierra, en el sentido de mundo". A Pachamama exige respeito, cooperação e reciprocidade, constituindo a regra ética e constitucional do Buen Vivir. Por estarmos nela, ela não tem localização espacial e não há um templo ou morada em que viva porque é a vida mesma, está por toda parte (Idem).

A diversidade de culturas que concebem as suas naturezas ou pachamamas revelam uma abertura na construção das redes de relações entre humanos, outros seres vivos e os objetos inanimados (GUDYNAS, 2011, p. 264). O olhar quéchua ou aymara no Equador, Peru ou Bolívia sobre pachamama possui muitas vertentes, mas todas apontam para um

\footnotetext{
${ }^{78}$ Para Hadot (2006, p. 338): "a natureza é arte e a arte natureza". Sua abordagem filosófica aponta que o melhor caminho para se conhecer a natureza seria através de um conhecimento racional que dialogue com as manifestações artísticas.

79 Santamaría (2011, p. 226) destaca alguns pontos importantes da ruptura da concepção da Constituição do Equador com as estruturas tradicionais do Direito. Para ele: "No cabe ya el término genérico de "derechos humanos" para referirse a los derechos que tienen una protección especial en las Constituciones. Conviene denominarlos derechos fundamentales o derechos constitucionales. Otra ruptura es que la protección a la naturaleza no se la hace porque conviene al ser humano, sino por la naturaleza en sí misma. En consecuencia, la concepción jurídica de los derechos deja de ser antropocéntrica. Terceira ruptura, la teoría jurídica tradicional para entender el derecho tiene que buscar nuevos fundamentos y renovadas lecturas, que tienen que ver con la ruptura del formalismo jurídico y con una superación de la cultura jurídica imperante".
} 
vínculo mais igualitário com o ambiente. Para Nina Pacari, uma importante liderança do movimento indígena do Equador, o mundo dos povos indígenas é a "allpa-mama" que, significa "madre-tierra". E, indaga: Por que allpa-mama? "Primero, hay una identidade de género: es mujer. Segundo, es lo más grande y sagrado, es la generadora de vida y producción; sin ella, caemos en la nada, simplemente somos la nada o no somos nadie, como dicen nuestros abuelos". E lembra a sabedoria dos mais velhos: "a una madre no se la vende, la allpa-mama no está para ser vendida" (PACARI, 2009, p. 34-5).

A ética do "buen vivir" e o direito da natureza constituem o que Leff (2014, p. 361) chama de imaginários do viver bem, que além de expressar suas formas de ser desde dentro do cosmo e da Terra, também instituem práticas de convivência e de transformação do local onde vivem, conjugando condições ecológicas do território com a arte do manejo cultural da natureza. Esses imaginários sociais da sustentabilidade:

Se presentan como las raíces profundas de formas de sociabilidad de la naturaleza instauradas em los hábitus y prácticas que se han instituido en las formaciones histórico-culturales de los pueblos y sus ecosistemas, que han resistido a las formas de dominación de la racionalidad moderna, y que hoy ofrecen vías para el reordenamiento de la vida en el planeta, en la perspectiva de la sustentabilidad de la tierra y la producción de la existencia humana (LEEF, 2014, p. 363).

Chegando aos kaiowá-guarani e a sua ética de vida na terra, "o teko porã ou as regras do bom viver kaiowá se constitui enquanto edifício conceitual normativo e representa a situação ideal de vida, em que se atingiria o coeficiente ótimo de estabilidade nas relações sociais em geral" (PEREIRA, 2004, p. 293).

Na sua concepção, o cosmos possui dois eixos: 1) vertical, composto por três planos: a) yvy - a terra; b) pa'irei - o mundo subterrâneo; c) yvaga - o céu ou paraíso; 2) horizontal, formado pelo leste, associado ao sol e, pelo oeste, vinculado a seres imperfeitos. No mundo subterrâneo habitam seres horripilantes que provocam terror. Ao céu estão reservados os atributos da perfeição e do divino, em que o humano deve se inspirar. Já a terra é o lugar da humanidade. A terra é um ser dinâmico, com ciclos de vida e morte. A síntese deste pensamento está expressa em Pereira (2004, p. 251) em que:

\begin{abstract}
a terra "nasce, vive e morre" e, as transformações pelas quais ela passa podem derivar de uma ordem de causalidade interna, dependendo do estágio de seu desenvolvimento ou das relações entre a diversidade de seus habitantes: humanos, espíritos, seres míticos e espécies de jara. Os homens não possuem e dominam a terra, ela não está inteiramente sujeita aos seus desígnios, eles simplesmente a habitam juntamente com outros seres, com os quais negociam o tempo todo as condições para o desenvolvimento de sua formação social. Ainda assim, a deteriorização das relações entre os homens, quando a ordem social é esfacelada, pode ser uma das causas de destruição da terra, e, nesse caso, os homens teriam uma participação determinante na sua destruição.
\end{abstract}

Yvy é o habitat da humanidade e também dos vegetais e animais e dos seus jara, ou seja, dos seus donos. Já a yvy maranéy yé o solo ou a terra intacta. Melía, ao analisar a 
acepção mais antiga do termo, ou seja, a de um solo virgem, conclui que a sua busca pode ter provocado deslocamentos e migrações pelos guarani. Para ele:

En la búsqueda de un suelo donde poder vivir su modo de ser auténtico, los Guaraní pueden haber hecho cristalizar tanto sus antiguas aspiraciones religiosas como la consciencia de los nuevos conflitos históricos. Yvy marane'ỹ se convertía en "tierra sin mal", tierra física, como en su acepción antigua, y a la vez tierra mística, después de tanta migración frustada (Meliá, 1988, p.108).

Tanto yvy quanto os ava (homem guarani) fazem parte do cosmo e foram criados por Ñanderú Guasu (nosso grande pai) através das primeiras sementes por ele plantadas na terra. Esse ato reforça o forte sentimento de pertença dos ava à terra. Portanto, as ações através do seu modo de ser devem ser voltadas para a manutenção e cuidado da terra e do equilíbrio cósmico. As metáforas da cosmologia kaiowá-guarani são ligadas ao corpo humano e as suas funções, como alimentar e descansar são consideradas importantes para a fisiologia da terra. São exemplos, a prática da coivara e o plantio do milho.

É por isso que os Kaiowa e os Ñandéva entendem que a prática da coivara possibilita que a terra "se alimente" em repouso por longos períodos, com o que recupera robustez que se manifesta no reflorestamento espontâneo (omboka'aguyjevy) decorrente do período em que está em repouso; no lugar do cultivo, interrompido temporariamente, nascerá, da terra, com o que o homem se alimentar. As plantas, em especial o milho, considerado sagrado, são tratadas como criança, colocando-se mais uma vez em destaque a visão antropomorfa dos elementos da natureza (THOMAZ DE ALMEIDA, 2005, p. 32).

O fortalecimento das relações dos ava com o cosmo é feita pelas rezas e rituais através da ação xamânica para conservar a terra, esta considerada também um ser vivente. O modo de ser dos kaiowá-guarani (ñande reko) está associado à qualidade da terra. O seu descumprimento implica no risco de catástrofes e de destruição da terra, que segundo Thomaz de Almeida (2005, p. 32), "pode ser exposto sob forma de uma equação: terra reduzida $=$ modo de ser (teko) enfraquecido".

\subsubsection{Interfaces indígenas: natureza e sociedade}

Existem alguns pontos de contato entre as chamadas éticas ambientais desenvolvidas teoricamente por autores americanos e europeus para pensar as relações entre humanos e não-humanos e as cosmologias indígenas na América. São as correntes nãoantropocêntricas que mais se aproximam destas cosmologias. Uma relação de complementariedade e uma visão holística, de que somos parte de um todo, é o que prevalece. No entanto, há peculiaridades que foram bastante trabalhadas por Descola e Viveiro de Castro ao discutem as relações entre humanos, natureza e sobrenatureza em povos indígenas na América, que passo a analisar. 
As chamadas interações/relações natureza/sociedade invocam uma série de posições teóricas. O pensamento ocidental hegemônico historicamente se pautou no dualismo entre natureza e cultura. A antropologia estruturalista ou simbólica utilizou esse dualismo como categoria analítica, que segundo Descola e Pálsson (2001, p. 13) teve o:

\begin{abstract}
objeto de dar sentido a mitos, rituales, sistemas de clasificación, simbolismos del cuerpo y de la comida y muchos otros aspectos de la vida social que implican una discriminación conceptual entre cualidades sensibles, propiedades tangibles y atributos definitorios.
\end{abstract}

As críticas mais comuns sobre essa dicotomia recaem nos seguintes argumentos: a dificuldade de uma compreensão que seja verdadeiramente ecológica, pois, não enxergam as formas locais de saber ecológico; o predomínio da relação de poder do conhecimento ocidental; uma epistemologia que se estende a outras oposições, como: mente-corpo, sujeito-objeto, indivíduo-sociedade etc (DESCOLA, PÁLSSON, 2001, p. 12-5).

Para que se possa superar o dualismo é necessário criar alternativas teóricas e metodológicas. Para além das tradições biológicas e antropológicas, Descola e Pálsson (2001, p. 30) propõem um sistema irredutível entre pessoa e meio ambiente, em que a pessoa é parte do meio ambiente e o meio ambiente é parte da pessoa. Nesta concepção, o foco são os processos e as relações.

As visões monistas que são localizadas e específicas de uma dada cultura em termos de poder são subjugadas. No monismo podem ser encontradas algumas relações, tais como: animais e plantas têm comportamentos humanos; animais e plantas são regulados por regras sociais; humanos podem transformar-se em animais; relações entre humanos e não-humanos fazem parte de uma dinâmica de transformações e reciprocidade.

As relações dos humanos com não-humanos são identificadas através do naturalismo, do totemismo e do animismo, que podem interagir, criando novos modos entre si. $O$ naturalismo é originário das cosmologias ocidentais desde Platão e Aristóteles e estruturou nossa epistemologia. Resulta na ideia de que a natureza existe e os entes devem a sua existência e seu desenvolvimento a um princípio alheio ao acaso, bem como aos efeitos da vontade humana (Descola, 2000, p. 161). Sua ontologia se baseia na justificativa através de causas, quer sejam realistas ou transcendentais.

No totemismo as plantas e os animais possuem atributos antropomórficos, como intencionalidade, subjetividade, afetos e características sociais, porém, não é relacional. No animismo, humanos e não-humanos possuem uma mesma natureza. Para Descola (2011, p. 91), plantas e animais são concebidos "como personas dotadas de un alma que les permite comunicarse con los humanos, y es en razón de esta esencia interna común que los no humanos son llamados a llevar una existencia social idéntica a la de los hombres". Em comparação, o totemismo e o animismo: 
Nos sistemas totêmicos, as plantas e os animais funcionam como operadores privilegiados do pensamento taxionômico; nos sistemas anímicos, plantas e animais aparecem propriamente como pessoas, são singularidades irredutíveis, e não classes. Nos sistemas totêmicos, em suma, os não humanos são tratados como signos; nos sistemas anímicos, são tratados como o termo de uma relação (DESCOLA, 2000, p. 160-1).

Pensando essa interação Descola e Pálsson (2001, p. 29) formularam um modelo transformacional a partir de três dimensões da vida social ${ }^{80}$ : modos de identificação; modos de interação e modos de classificação. Para isto, é necessário ir mais além da mera descrição de sistemas locais de relações humano-ambiente. Neste contexto, a riqueza da experiência etnográfica pode apontar caminhos para um projeto comparativo mais criativo e imaginativo. Descola chama os povos indígenas de "sociedades da natureza", em que:

las plantas, los animales y otras entidades pertenecen a una comunidad sociocósmica, sujeta a las mismas reglas que los humanos; cualquier descripción de su vida social debe, por fuerza, incluir los componentes del medio ambiente que son vistos como parte del dominio social" (DESCOLA, PÁLSSON, 2001, p. 25).

Já Viveiro de Castro (2011) propõe a ideia relacional de perspectivismo para pensar o binarismo natureza/cultura. Na sua concepção, baseada em etnografias de povos indígenas da Amazônia, o perspectivismo não se aplica a todos os animais ${ }^{81}$ e a "personitude" e a "perspectividade", ou seja, a capacidade de ocupar um dado ponto de vista constitui uma questão de grau e de situação do não-humano. Outro ponto importante nesta relação é que alguns seres podem se apresentar de modo mais completo do que outros e até mesmo do que o ser humano (VIVEIRO DE CASTRO, 2011, p. 353). A noção de espíritos ou "donos dos animais" está presente em várias cosmologias indígenas. Em sua análise:

\begin{abstract}
Esses espíritos-mestres, invariavelmente dotados de uma intencionalidade análoga à humana, funcionam como hipóstases das espécies animais a que estão associados, criando um campo intersubjetivo humano-animal mesmo ali onde os animais empíricos não são espiritualizados. Acrescente-se que a distinção entre os animais vistos sob seu aspecto-alma e os espíritosmestres das espécies nem sempre é clara ou pertinente; de resto, é sempre possível que aquilo que, ao toparmos com ele na mata, parecia ser apenas um bicho revele-se como o disfarce de um espírito de natureza completamente diferente (VIVEIRO DE CASTRO, 2011, p. 354).
\end{abstract}

\footnotetext{
80 "Modos de identificación, o el processo por el cual las fronteras ontológicas se crean y se objetifican en sistemas cosmológicos como el animismo, el totemismo o el naturalismo; modos de interacción que organizan las relaciones entre las esferas de humanos y no humanos, así como dentro de cada una de ellas, de acuerdo con principios como los de reciprocidad, rapacidad o protección, y modos de clasificación (básicamente el esquema metafórico y el esquema metonímico), por médio del cual los componentes elementales del mundo son representados como categorías socialmente reconocidas" (DESCOLA, PÁLSSON, 2001, p. 29).

81 "Ele parece incidir mais frequentemente sobre espécies como os grandes predadores e carniceiros, tais o jaguar, a sucuri, os urubus ou a harpia, bem como sobre as presas típicas dos humanos, tais o pecari, os macacos, os peixes, o veado ou a anta. Pois, uma das dimensões básicas, talvez mesmo a dimensão constitutiva, das inversões perspectivas diz respeito aos estatutos relativos e relacionais de predador e presa" (VIVEIRO DE CASTRO, 2011, p. 353).
} 
Existe uma série de possibilidades de estudos da antropologia contemporânea sobre a natureza. Ulloa (2011, p. 30) sintetiza alguns destes temas e do que poderia ser uma agenda de pesquisas futuras:

\begin{abstract}
El replanteamiento de las categorías de naturaleza/cultura, la pérdida tanto de conocimientos como de la biodiversidad misma, las propuestas concretas para confrontar el deterioro ambiental, la necesidad de etnografías densas sobre prácticas y conocimientos en lugares específicos, el seguimiento de las genealogías de los discursos ambientales, las políticas globales y su incidencia en lo local, hasta el activismo político frente a los derechos de los humanos y de los no humanos.
\end{abstract}

Tim Ingold propõe uma antropologia das pessoas que esteja contida em uma biologia dos organismos, em um contexto de pós-darwinismo, cujo enfoque está centrado nos processos mais do que nos eventos. É um diálogo entre a antropologia e a biologia que é diferente da sociobiologia. Na sua visão, o campo relacional da pessoa ocorre entre sua base biológica e a vida social, pois: "una adecuada integración de la antropología en el campo más amplio de la biología requiere que el estudio de las personas se incluya bajo el estudio de los organismos" (INGOLD, 2011b, p. 126). Sua proposta reside numa integração de uma teoria das pessoas com uma teoria mais geral dos organismos, todavia, "sin comprometer el rol de la agencia humana o negar la creatividad esencial de la vida social" (INGOLD, 2011b, p. 127).

\title{
2.2.3 Os jara como donos dos seres na terra
}

O mito de criação dos guarani tem como centralidade o ciclo dos gêmeos. Existem muitas versões a depender do narrador e do autor ${ }^{82}$ que o transcreveu e o interpretou. Muitas delas foram escritas com base em relatos de informantes e formam estruturas metodológicas com elementos comuns, mas também com variações episódicas. Além deste, existem vários outros temas míticos dos quais se depreende a origem de plantas e animais, revelando a sacralidade da natureza e suas relações com a humanidade.

Segundo Bartolomé (1991, p. 80), o panteão religioso dos Ava-Katu-Ete é formado por Ñanderú Guasu e Ñandesý como os deuses fundadores, depois pelos heróis culturais Kuarahy e Jasy, respectivamente, irmãos sol e lua (mito dos gêmeos). Seguido por uma deidade urânica, Tupã. Pelos pássaros mensageiros: Paraka'o, Tape, Maino, Kusuva. Abaixo vêm os Añag/jaguares, que são figuras malignas e pelos salvadores Jarýipire/xamãs divinos. A mediação é feita pelo xamã. Havendo também a presença de espíritos de plantas e animais (jara). Chamorro (2008, p. 123) ao narrar relatos míticos de grupos guarani mbýa e kaiová/paĩ-tavyterã faz a referência a Jasuka, uma espécie de "princípio ativo do universo". Sua narração sobre os heróis culturais encontra-se no Anexo.

\footnotetext{
${ }^{82}$ Vide as narrações em Unkel (1987), Bartolomé (1991) e Chamorro (2008).
} 
O mito é algo vivo, dinâmico, calcado em tradições orais em que uma geração transmite seu saber a outra através de narrações e ações. O mito é vivido pela realidade de quem o experimenta. Como pontua Overing (1995, p. 110):

(...) o mito é o gênero por meio do qual a cosmologia indígena se revela. É por intermédio do mito que os postulados referentes ao universo se exprimem e se explicam. Os ciclos míticos abordam questões metafísicas básicas a respeito da história e do desenvolvimento dos tipos de coisas ou seres que há no mundo, e também suas modalidades de ser e relacionamentos.

No trabalho de campo, em todas as terras pesquisadas ouvi histórias sobre mitos, principalmente, por parte de rezadores e lideranças. Em Jatayvary (capítulo 5), a liderança me narrou vários aspectos do mito de criação, com base na memória dos antepassados do que aprendeu ao longo da vida. Na sua interpretação aparecem vários elementos e personagens do mito de criação.

$\mathrm{Na}$ tradição oral da cosmologia guarani cada qual recria, reinventa, resignifica o mito de criação. E segue fazendo pontes e conexões com o mundo atual, com sua vida, construindo significados da relação dos seres humanos com os outros seres da natureza.

Cada qual vive o mito. Isto condiz com a análise de Eliade (1994, p. 21):

$\mathrm{Na}$ maioria dos casos, não basta conhecer o mito da origem, é preciso recitá-lo; em certo sentido, é uma proclamação e uma demonstração do próprio conhecimento. E não é só: recitando ou celebrando o mito da origem, o indivíduo deixa-se impregnar pela atmosfera sagrada na qual se desenrolaram esses eventos miraculosos. O tempo mítico das origens é um tempo "forte", porque foi transfigurado pela presença ativa e criadora dos Entes sobrenaturais. Ao recitar os mitos, reintegra-se àquele tempo fabulosos e a pessoa torna-se, consequentemente, "contemporânea", de certo modo, dos eventos evocados, compartilha da presença dos Deuses ou dos Heróis. Numa fórmula sumária, poderíamos dizer que, ao "viver" os mitos, sai-se do tempo profano, cronológico, ingressando num tempo qualitativamente diferente, um tempo "sagrado", ao mesmo tempo primordial e indefinidamente recuperável.

O mito constitui a própria verdade e orienta o modo de ser kaiowá-guarani e as práticas da cultura que são vividas individual e coletivamente. O mito precisa ser vivido, praticado, sentido e percebido. Como afirma Eliade (1994, p.11): "O mito é uma realidade cultural extremamente complexa, que pode ser abordada e interpretada através de perspectivas múltiplas e complementares".

Há várias explicações sobre a criação do mundo e formas de pensar a sua relação com o mundo. Apesar de existir uma unidade de explicação com elementos comuns, a experiência vivida por cada indígena revela peculiaridades. A rezadora de Jatayvary falou que: "a história não tá nos livros, tá na mente da gente. O que sabemos não tá escrito no papel". O mito ensina "'histórias" primordiais que o constituíram existencialmente, e tudo o que se relaciona com a sua existência e com o seu próprio modo de existir no cosmo o afeta diretamente" (ELIADE, 1994, p. 16). 
O mito também faz previsões. O mito guarani é apocalíptico sobre o fim do mundo. mundo ainda não acabou porque a reza mantém a sustentação do mundo fazendo a conexão entre terra, água e céu. Daí resulta a importância dos rezadores e dos rituais.

Há uma importante passagem narrada por Nimuendaju Unkel (1987, p. 71) ao tratar da profecia da catástrofe do dilúvio. Diante do relato: "hoje a terra está velha, nossa raça não quer mais se multiplicar; iremos rever todos os mortos, as trevas finalmente cairão, etc." Ele analisa:

Não é só a tribo dos Guarani que está velha e cansada de viver, mas é toda a natureza. Quando os pajés, em seus sonhos, vão ter com Ñanderuvuçú, ouvem muitas vezes como a terra Ihe implora: "devorei cadáveres demais, estou farta e cansada, ponha um fim a isto, meu pai!" E assim também clama a água ao criador, para que a deixe descansar; e assim também as árvores, que fornecem a lenha e o material de construção; e assim todo o resto da natureza. Diariamente se espera que Ñanderuvuçú atenda às súplicas da sua criação (Idem).

Os mitos guarani rompem epistemologicamente com pensamentos racionalistas duais. Aliás, como afirma Overing (1995, p. 112): "do ponto de vista do cientista, os postulados indígenas a respeito da mitologia são fantasmagóricos". Muitas das proposições científicas sobre a natureza são incompatíveis com a mitologia indígena, o que nos coloca mais uma vez diante dos dualismos face à relação do ser humano e dos outros (natureza e entes sobrenaturais). As metáforas da natureza reveladas pelos mitos carregam consigo preciosidades para ser e estar no mundo. Na mitologia kaiowá-guarani a relação com os jara aponta caminhos para uma melhor convivência.

Os jara são espíritos ou donos de diversos seres que habitam a terra. Segundo Chamorro (2008, p. 166): "a terminação jára, "dono", indica que os seres denominados sob o epíteto Tekojára são os que conferem características animistas à religião guarani". A comunicação entre os kaiowá e os demais seres não-humanos com os jara ocorre através da linguagem religiosa.

Para Pereira (2004, p. 232-3) existem diversas categorias de jara ${ }^{83}$, conforme a relação estabelecida entre os kaiowá e os seres não-humanos em um dado espaço (domínios):

Assim, temos os jara para: morros de pedra, pântanos, florestas, plantas agrícolas e os diversos tipos de animais silvestres (mymbá) e domésticos (rymbá). Esta classificação parte do postulado da existência de vida social e disposições antropocêntricas de intensidade variável em cada uma destas modalidades. Cada modalidade de interação segue o estilo de vida impresso por seu jara, com o qual os indivíduos aí residentes desenvolvem uma relação de deferência, respeito e dependência.

\footnotetext{
${ }^{83}$ Para uma análise sobre outros jara, como: jakaira (dono das plantas agrícolas); so'o jara (dono dos animais) e kaja’a (dono dos seres da água), vide Pereira (2004).
} 
Os espaços socializados pelos kaiowá são as casas e as roças. A floresta (ka'aguy) segundo Pereira (2004, p. 171-2) pode ser pensada de duas formas: 1) como espaço com cobertura vegetal, onde vivem os não-humanos, animais e espíritos; 2) como espaço onde ocorrem atividades de caça e coleta. Para os kaiowá, além dos conhecimentos sobre o manejo da mata, o grande diferencial, é o estabelecimento de boas relações com os jara que vivem lá (Idem, p. 173).

Os ka'aguy jara, dono da floresta, é aquele responsável pelo crescimento das plantas na floresta. Os kaiowá tinham a percepção de que as matas eram infinitas no seu território de ocupação tradicional. "A existência da mata não era motivo de preocupação, ela sempre se manteve praticamente inalterada, regenerando-se dos impactos resultados da ação antrópica pontual para a realização de roças, casas, caminhos, etc" (PEREIRA, 2004, p. 248).

Os processos de colonização impuseram uma realidade de destruição de ecossistemas e escassez de elementos da natureza. Como resultado dessas ações humanas, o ka'aguy jara lança doenças sobre a terra. "Via de regra, a origem da doença está na infração de uma regra de convivência com algum ser xamânico, seja alguma espécie de jara, seja um xamã humano. Assim, na maioria dos casos, a doença é produto da vingança" (PEREIRA, 2004, p. 248-9).

A entrada na mata pelos kaiowá deve ser feita com um pedido de licença para o ka'aguy jara, sob pena de se sofrer algum mal. Da mesma forma, se precisar retirar algo da mata, como madeira, planta medicinal ou caçar. O ritual da reza para a entrada na mata e para a retirada da raspa de algumas árvores estão descritos no capítulo 4, sobre o dono da mata. É ilustrativa a citação de Pereira (2004, p. 249) sobre o corte de árvore:

Essa entidade é muito ciosa dos seres sob seus cuidados: a madeira quando cortada sente dor, geme e chora. Seu dono logo vem em seu auxílio, podendo ser mortal para o desavisado. Segundo os kaiowá, antigamente o xamã chegava no lugar escolhido para a derrubada da futura lavoura, rezava convocando o ka'aguy jara para explicar que eram humanos pobres, não tinham de onde tirar o sustento, por isso necessitavam de derrubar um pequeno pedaço da mata para plantar seu alimento. $O$ pedido era sempre atendido e poderiam plantar tranquilamente, pois não seriam atingidos por nenhuma moléstia.

Os donos ou guardiões podem ser encontrados em diversas culturas indígenas americanas. Sobre as cosmologias amazônicas, Descola (2000, p. 154), percebe que não existem diferenças ontológicas absolutas entre humanos e boa parte dos animais e vegetais. Suas diferenças seriam de grau e não de natureza. Para os achuares da Amazônia equatorial:

(...) a maior parte das plantas e dos animais possui uma alma (wakan) semelhante à dos humanos, uma faculdade que os põe entre as "pessoas" (aents), uma vez que lhes garante a consciência reflexiva e a intencionalidade, torna-os capazes de experimentar emoções e permite-lhes 
trocar mensagens com seus pares e com outros membros de outras espécies, entre as quais os homens" (DESCOLA, 2000, p. 151).

Já para os macunas, Descola (2000, p. 153) coloca que:

As categorizações ontológicas são, entretanto, ainda muito mais plásticas do que entre os achuares, em razão da faculdade de metamorfose atribuída a todos: os humanos podem tornar-se animais, os animais podem converter-se em humanos e o animal de uma espécie pode transformar-se em um animal de outra espécie.

As percepções sobre a terra podem se expressar através dos mitos e de como eles são vividos por um determinado povo. Os mitos da natureza trazem consigo uma ética ou normatividade ambiental. Os jara simbolicamente servem para regular o acesso aos recursos naturais. Para os nahuas do sul de Veracruz, Mx, são os chaneques e dueños de los animales.

Apesar desta tese não ter como objetivo a comparação de sistemas sociais indígenas entre os kaiowá-guarani e os nahuas da Sierra de Santa Marta ao sul de Veracruz, impressiona as semelhanças descritas por Lazos e Paré (2005, p. 199) sobre a relação do corpus mítico dos nahuas, através dos chaneques ${ }^{84}$ e dueños de los animales e os jara ou donos dos seres para os kaiowá-guarani, bem como suas regras de acesso aos recursos naturais:

Las prohibiciones que se ponen en boca de los chaneques constituían medidas para vivir de la tierra com un respeto hacia ella, para mantener los recursos que en ella proliferan. Éstas no sólo representaban una normatividad de tipo restrictivo, sino que entrañaban beneficios toda vez que los seres sobrenaturales ofrecían protección si se cumplía con los códigos de conducta. Fundamental en estas reglas es la idea de reciprocidad (LAZOS, PARÉ, 2005, p. 199).

Os chaneques funcionam como uma instituição regulatória entre a economia e a ecologia para os nahuas, em que as regras de comportamento destes para com os demais seres vivos se baseiam na ideia de reciprocidade. Segundo Lazos e Paré (2005, p. 66):

Hasta donde entendimos su pensamiento, los humanos comparten el mundo con estos seres y no deben servirse de ellos más allá de lo necesario para sobrevivir. Se podría decir que la satisfacción de las necesidades individuales y de las familias de la comunidad marca el límite de un uso correcto, o como se diría hoy, sustentable. Esto no excluye la posibilidad del intercambio por trueque o comercial pero dentro de los límites de las necesidades comunitarias. Cazar, pescar o recolectar para lucrar significa una extracción desmedida que tiende a una acumulación

\footnotetext{
84 "Los chaneques, personajes pequeños o grandes, femeninos o masculinos, blancos o negros controlaban, a través del imaginario colectivo de los nahuas, el acceso a los recursos naturales. Estos duendecillos que se aparecen bajo distintas formas podían enojarse y provocar enfermidades, sustos y encantos cuando alguien transgredía las limitaciones impuestas en la apropiación de la naturaleza. Los chaneques son el fruto de la imaginación, la concretización de los miedos y angustias y expresan la voluntad de um respecto. Moradores de las florestas, son dueños de los recursos que en ellas proliferan. Por tanto, tienen derechos y obligaciones: exigen respecto a las regulaciones pero también otorgan protección" (LAZOS, PARÉ, 2005, p. 56).
} 
mediante la cual uno se vuelve "más rico" que los demás y ocasiona desequilibrios tanto sociales como ecológicos.

Também na Serra de Santa Marta, os nahuas adotavam um sistema de agricultura baseado em "roza-tumba y quema" que foi desestruturado pelo avanço da fronteira agrícola. Outro ponto em comum entre os kaiowá e os nahuas sobre a percepção dos mais velhos ${ }^{85}$ acerca da recuperação da terra diante da degradação ambiental é que:

Los ciclos naturales se encargarán de restaurar lo dañado. Entre estas personas mayores, las explicaciones míticas son recurrientes para explicar lo que está pasando. Los chaneques castigan las faltas cometidas por los hombres em su relación con los seres del monte, pero también tienen la capacidad de perdonar y cesar los castigos. Entonces, cuando los hombres sean perdonados, volverá la abundancia y la riqueza de flora y fauna (LAZOS, PARÉ, 2005, p. 201).

A ideia cosmológica de que os donos ou senhores dos animais retiraram ou guardaram os seres das matas ou florestas como uma consequência das transgressões a normas estabelecidas perpassa muitas culturas indígenas latinoamericanas. Para Lazos e Paré (2005, p. 68-9) analisando o simbólico dos nahuas, há dois caminhos: a) os humanos não podem intervir na restauração da natureza porque não têm este poder de atuação. As autoras se referem a uma fala de um ancião nahua sobre o fracasso de um projeto de reflorestamento: "dice que el proyecto de reforestación fracasó porque no se había pedido permiso al Dueño del monte"; b) há possibilidade do restabelecimento da ordem natural quando se recupere as normas estabelecidas com os donos dos seres. Esta concepção é importante para todo trabalho de educação ambiental de restauração.

Para Viola (1997, p. 20) a interdisciplinaridade exigida pelos estudos científicos da natureza tem propiciado um interesse pelos significados cosmológicos e junto com ele uma visão unitária da natureza. Esse "retorno à cosmologia" é um sinal da entrada da ciência na pós-modernidade. Isto porque:

Durante la modernidad la cosmología y la filosofía de la naturaleza habían sido eliminadas, por considerarlas un residuo molesto de las viejas cosmologías míticas, que explicaban narrativamente el orden del mundo como un proceso contigente, que dependía de las vicisitudes de los dioses o de los héroes (VIOLA, 1997, p. 20).

Os processos de colonização subjugaram os conhecimentos das populações nativas, colocando o mito em um lugar menor e distante, como algo mentiroso e falso. Interessante pensar como Overing (1995, p.111), ao afirmar que: "o "problema" do mito não é uma questão de deficiência, e sim de excesso".

\footnotetext{
85 "Para muchos ancianos y ancianas, la deforestación y la pérdida de biodiversidad animal - tanto de la fauna acuática como de la fauna selvática - se atribuyen a que el Señor del monte escondió adentro de los cerros y montes - em el bayo - a toda la fauna y a la vegetación con el fin de protegerlas del humano. Es reiterativa la referencia a que los animales se fueron a otro lado en lugar de pensar que quizá ya se hayan exterminado". Esta assertiva também existe para várias partes do mundo rural do México, como em Oaxaca, Chiapas, Veracruz e Tabasco (LAZOS, PARÉ, 2005, p. 67).
} 


\section{TERRA TE' ÝIKUE}

\subsection{A ALDEIA ANTIGA E SEU POVO}

A constituição da reserva Indígena Te'ýikue, no município de Caarapó, está inserida no contexto das oito reservas, no total de 18.297 ha, que foram criadas pelo SPI entre os anos de 1915 a 1928. Inicialmente, a chamada de Reserva Indígena José Bonifácio ${ }^{86}$ foi criada por Decreto Presidencial em 20/11/1924, com uma área de 3.600 ha e, posteriormente, reduzida para 3.594 ha. Juridicamente se encontra homologada a demarcação administrativa pelo Decreto n. 250 de 29/10/91 e com registro pelo SPU.

Foi a terceira das oito reservas criadas no sul de MS, cuja finalidade era "aldear os índios que prestavam serviços nos ervais, uma vez que a fazenda campanário, de propriedade da Cia. Matte Larangeira, estava localizada nas proximidades", (MOREIRA DA SILVA, 2002, p. 56). Conforme os mais antigos, "no começo não tinha mais do que 30 pessoas morando na Aldeia. Tudo era mato fechado, com muita caça e pesca. Dizem eles que usavam o fogo para preparar as roças e que havia muita união e respeito entre as pessoas" (UCDB, 2009, p. 12). Com o tempo, a população foi aumentando vertiginosamente, pois, as famílias indígenas de outras regiões foram sendo expulsas e levadas para as reservas criadas.

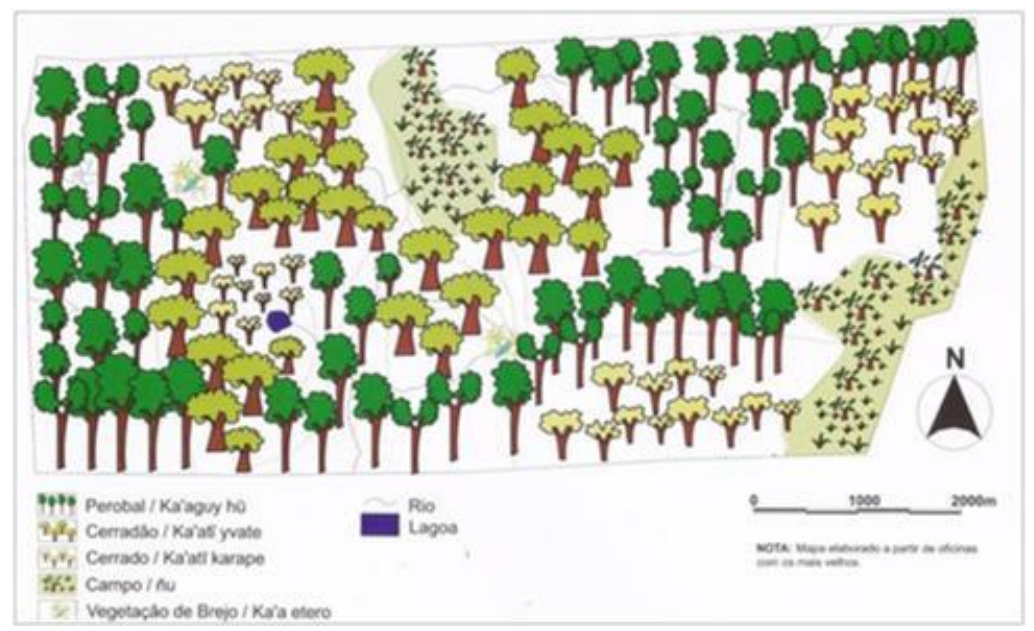

Mapa 2 - Representação da Reserva Indígena Te'ýikue na época da criação.

Fonte: UCDB, 2009, p. 15.

\footnotetext{
${ }^{86}$ Segundo Relatório do inspetor Antonio Estigarribia e do seu auxiliar Genésio Pimentel Barbosa sobre a situação do Posto Indígena José Bonifácio: "em 20 de novembro de 1924 o Governo do Estado, no exercício do Sr. Dr. Estevão Alves Correia, pelo decreto n. 684, reservou para os índios Cayuás, 3.600 hectares de terras no lugar denominado Rincão do Bonfim, satisfazendo assim a solicitação desta Inspectoria em offcio n. 352 de 22 de Outubro do mesmo anno. Medidas essas terras, foi fundado ahi em Abril de 1927 o posto que, pelo numero de índios, sua boa disposição para o trabalho e qualidades dos hervaes é certamente dos mais esperançosos de Matto-Grosso. Antes da fundação, vivião os índios brigados entre si e explorados por traficantes de herva que no seu interesse promovião taes dissenções" (MONTEIRO, 2003, P. 34).
} 
Segundo Eliel Benites (2014, p. 42), "a palavra Te'ýikue significa te'ýi (gente, homem) e kue como sufixo da palavra para designar o passado, ou aquilo que já foi; assim, o termo Te'ýikue foi sendo traduzido como aldeia antiga". Os nomes das regiões de Te'ýikue segundo os mais velhos se remetem a animais, a plantas e a aspectos geográficos, como: Sãka Pytã: voçoroca vermelha; Mbokaja: coqueiro; Jaicha Syry: córrego da paca; Jakaira: dono do milho; Yryvu Kua: buraco do urubu; Mbopiy: córrego do morcego; Ñumbuku: campo extenso; Kuchui Ygua: bebedouro dos pássaros; Kanguery: córrego dos ossos; Ju'i Rase: choro da rã; Mbói Passo: passo da cobra; Ñandu Potrero: potrero de ema; Yvu: nascente e Itakuruvi: pedra que amola. (UCDB, 2009, p. 19-20).

Devido à ocupação e as transformações ambientais houve uma modificação na identificação das regiões, alguns nomes permaneceram e outros foram criados, conforme ilustra o mapa abaixo com as áreas atuais. Te'ýikue tem muitas paisagens. Os biomas presentes nessa terra são o cerrado e a floresta estacional semidecidual.

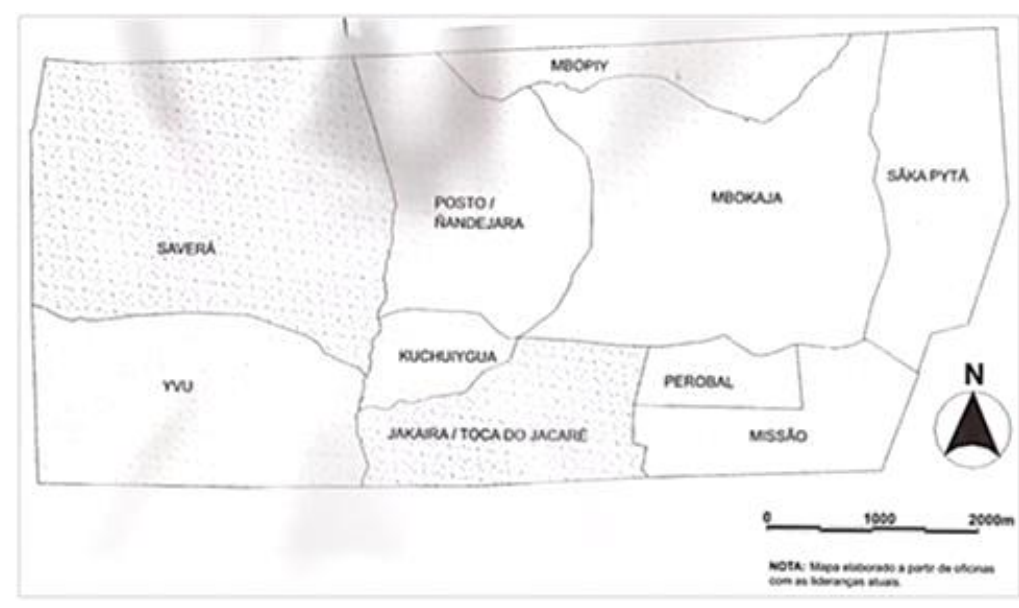

Mapa 3 - Regiões atuais da Reserva Indígena Te'ýikue. Fonte: UCDB, 2009, p. 15.

Sobre a população atual, segundo a liderança, existem cadastradas cinco mil e poucas pessoas, mas tem mais gente que não tem documento. Por isso, deve haver cerca de seis mil habitantes. Nem todos têm acesso à água encanada. Há duas torres de abastecimento: uma na região Posto/Ñandejara e outra na Missão. Então, as famílias que moram nessas redondezas são atendidas. As demais retiram água de poço, de córregos e de nascentes.

A região da Escola Municipal de Ensino Fundamental Ñandejara é como se fosse uma área central de Te'ýikue, pois, lá também se encontram a escola de Ensino Médio, o viveiro, o posto de saúde do SESAI, o CRAS (criado em 2004) e outros equipamentos. Foi nessa localidade onde se deu a criação do Posto Indígena pelo SPI. 


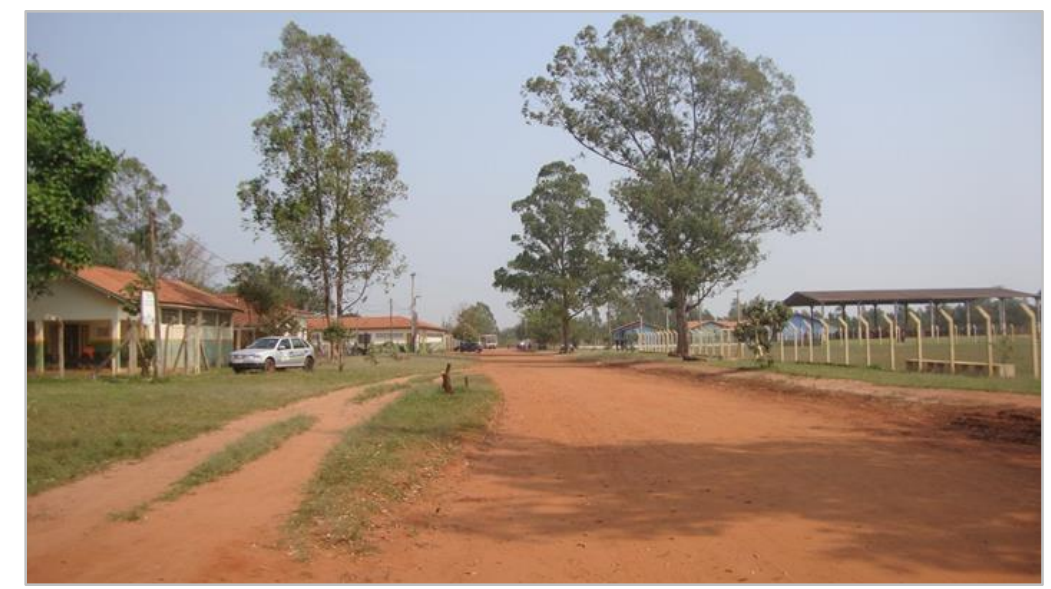

Fotografia 4 - Centro da Reserva Indígena Te'ýikue. Fonte: Autoria própria.

A justificativa das categorias de pessoas com as quais busquei conversar durante a pesquisa de campo está presente na introdução. Porém, em se tratando de uma terra com um alto contingente populacional, como é o caso de Téýikue e, com um número considerável de professores, foi necessário delimitar o processo de investigação para algumas pessoas centrais que fizeram parte da história da construção do modelo escolar implantado a partir de 1997.

Por isso, priorizei o contato com duas professoras da escola de ensino fundamental Ñandejara Pólo: uma indígena e outra não-indígena; com o diretor da escola de ensino médio; com o professor que coordena o projeto na unidade experimental e com os servidores do viveiro, no que diz respeito ao universo escolar. Quanto aos rezadores, foi possível a convivência com dois deles, os que mais colaboram com as atividades da escola, sendo que os demais estavam trabalhando ou passando uma temporada em outras terras no período em que realizei a pesquisa. Dos idosos, além dos rezadores, estive em contato com uma idosa e sua família na região de cerrado próxima aos limites da terra indígena. $\mathrm{E}$, por fim, mantive conversas com a liderança.

As pessoas com as quais conversei durante a pesquisa de campo, cujas falas estão presentes mais fortemente neste capítulo serão referenciadas como: professora indígena; professora não-indígena; diretor da escola; professor da unidade; servidor 1; servidor 2; servidor 3; rezador de Mbopiy; rezador de Mbokaja; idosa e liderança. 


\subsection{A ESCOLA E O TEMPO}

\subsubsection{O antes e o depois de 1997}

A educação indígena ${ }^{87}$ é algo sempre presente na vida das famílias, sendo uma atribuição passada de geração para geração através de ensinamentos, de vivências e da oralidade dentro da cultura e das interações realizadas interna e externamente. Ela se diferencia da educação escolar indígena, atribuída historicamente a diversas instituições na qual prevaleceu formalmente um modelo integracionista até bem pouco tempo.

Inicialmente, foram as primeiras ordens religiosas católicas que se instalaram no Brasil as responsáveis por essa função. Através do SPI, "instalou-se uma rede de escolas para educação de índios com ensino das chamadas "primeiras letras" e, sobretudo, de ofícios que os situassem como futuros trabalhadores" (LIMA, BARROSO, 2013, p. 49).

$\mathrm{Na}$ década de 1980/1990, diversas ONG's, a OPAN (Operação Anchieta) e o CIMI propuseram outros modelos de educação. As conquistas sociais previstas na Constituição de 1988 e as normas regulamentadoras deram o suporte normativo para mudanças em curso. O Plano Nacional de Educação, Decreto 10.172 de 09/01/2001, previu a formação superior de professores indígenas. Foi o primeiro plano posterior ao art. 214 da Constituição de 1988 e da Lei de Diretrizes e Bases da Educação Nacional (LDB), de 1996, principalmente, nos artigos 26, 32, 78 e 79.

Em Te'ýikue, "até 1997 a escola da aldeia, em Caarapó, era extensão da escola Tiradentes Pólo, Colônia Saiju localizada na área rural e adotava o modelo integracionista e/ou assimilacionista, oferecendo aos índios Kaiowá e Guarani o mesmo currículo das escolas da zona rural" (BATISTA, 2005, p. 14). Era uma educação em português que priorizava os conhecimentos não-indígenas. A evasão escolar e a repetência eram a regra, como demonstram os dados estatísticos levantados no início de 1997. Dados que: "comprovaram o descaso das administrações anteriores para com a educação escolar nas escolas da reserva indígena, que tinha, em 1996, 365 alunos, com uma média repetência de $47 \%$ e abandono escolar de $22 \% "$ (Idem, p. 76).

\footnotetext{
${ }^{87}$ É preciosa a lição de Meliá (1979, p.7) sobre o tema: "Educação pode dar-se muito bem sem alfabetização. Alfabetização, no entanto, nem sempre assegura uma boa educação. As sociedades indígenas brasileiras, como aliás, muitas outras sociedades em todo o mundo, se educaram perfeitamente durante séculos sem recorrer à alfabetização, conseguindo, com meios quase que exclusivamente orais, criar e transmitir uma rica herança cultural. A educação baseada na comunicação oral até apresenta não poucas vantagens sobre a baseada na escrita. Nas culturas orais nota-se uma participação mais homogeneizada e plena de todo o saber tradicional, uma grande riqueza de sabedoria proverbial, uma visão mais unitária do mundo, uma forte vivência do presente como tal, uma captação da vida como um todo e não simplesmente acumulação de coisas separadas. A alfabetização, de fato, incentiva a privatização do saber e contribui para um tipo de individualização que logo se manifesta fonte de tensões e conflitos sociais entre dominante e dominado".
} 
A ideia prevalecente para o professor não-índio era a de que dar aula na aldeia constituía um castigo ou uma perseguição política. Na dissertação de Batista (2005, p. 745), há um depoimento revelador de uma professora não-indígena, que trabalhou de 1980 a 1996 na escola de ensino fundamental em Te ýikue, sobre as dificuldades enfrentadas: falta de transporte, de água, de material escolar e dificuldades de comunicação. De acordo com essa professora, quando ela foi trabalhar na reserva não era porque queria. Era por ser adversária política. Então foi mandada para lá como castigo para que pedisse as contas. Como ela sabia o guarani por ser descendente de paraguaios, costumava iniciar o processo de alfabetização e depois os alunos seguiam com as demais professoras, já entendendo melhor o português (Idem).

Diante desse quadro, uma série de esforços começou a germinar no sentido de uma transformação não só da educação escolar indígena, mas também da melhoria das condições ambientais da terra. E, daí emergiram outras questões como a formação do professor, a melhoria da saúde e do meio ambiente, este um tema transversal da escola.

No início, houve muita resistência de algumas famílias ao ensino na língua materna, pois, entendiam que o guarani já era ensinado em casa e que a escola era o lugar de aprender português e com professores não-indígenas. Então, foi feito um trabalho de reflexão sobre o processo de alfabetização na língua materna, ou seja, como se pensa. A professora não-indígena pontuou que os pais tinham muita resistência com o guarani na escola, pois, pensavam o seguinte: "já falamos guarani com nossos filhos, pra quê estudar guarani?" No princípio, foram feitas aulas separadas em guarani e em português. Como o resultado dos alunos em guarani foi melhor, os demais migraram. Atualmente, os ensinos de educação infantil e os de $1^{\circ}$ e e $2^{\circ}$ ano só ocorrem na língua indígena. Do $3^{\circ}$ ano em diante é introduzido o português. E para o $6^{\circ}$ ao $9^{\circ}$ ano há também aulas de inglês, língua ensinada por solicitação dos alunos.

Segundo a professora indígena foi adotada a metodologia dos chamados temas geradores, que conduziram a teoria e a prática escolar a partir das realidades vivenciadas na comunidade:

na escola, a cada bimestre tem um tema. Se trabalham com temas geradores. Por exemplo: meio ambiente, então no primeiro bimestre, a questão da água, do reflorestamento, a queimada. Cada etapa do bimestre, se trabalha determinado assunto. Trabalha na sala e tenta colocar na prática, a importância que traz pra gente. Alguns têm consciência e questionam os adultos, por exemplo quando põe fogo. Antes fazia dos pais ensinar, fica meio ao contrário, dos filhos para os pais, lembrar o que não pode fazer. A maioria dos conteúdos é ligado ao meio ambiente.

A professora não-indígena relembra o início do da transformação do processo educacional:

o material didático era produzido por nós mesmos. Aulinha por aulinha. Semana por semana. Estudavam e preparavam todo o material pra sala de 
aula. Um trabalho pioneiro e muito bonito que deu muito resultado. Em 2003, o prefeito ganhou o prêmio Prefeito Criança da Abrinq, em nível nacional. Pegou uma educação com um resultado péssimo e em poucos anos, dá uma virada de qualidade e diferenciada pra realidade deles. Nós nos tornamos referência em nível estadual, nacional. Defender um projeto diferenciado que tem que respeitar uma cultura, pensa na dificuldade que é. Porque todo programa que vem, vem engessado, igual pra todo mundo.

O ano de 1997 foi o tempo da virada na construção das mudanças operadas em Te'ýikue através de articulações e de muitos diálogos. Várias parcerias entre a comunidade e instituições externas foram realizadas e resultaram em processos de transformação. $A$ parceria entre a secretaria municipal de educação, o CIMI e o Projeto Guarani Kaiowá, da UCDB foi fundamental para a construção de um novo modelo de educação escolar indígena. Modelo baseado no ensino da língua; numa gestão compartilhada da escola; na valorização do conhecimento da cultura kaiowá-guarani; na construção de metodologias e de recursos didáticos próprios; na formação de professores indígenas para atuarem nas escolas das terras indígenas; na criação de cursos específicos como o de formação de professores para o ensino fundamental, que foi chamado de Ará Verá.

E também, na construção e realização de projetos ambientais com a participação dos alunos e de suas famílias, da comunidade, de lideranças e de professores; de atividades de extensão e pesquisa como o viveiro de mudas e a unidade experimental; de reflorestamento; de recuperação de nascentes e de microbacias e o desenvolvimento de um Fórum de discussões das questões relevantes para Te'ýikue. Segundo Eliel Benites (2014, p. 92), "o espaço escolar foi se caracterizando como uma escola além das paredes. Quando a instituição foi absorvida pela comunidade, desnorteou a rigidez do espaço e do tempo escolar".

O modelo de escola e de recuperação ambiental foi muito dialogado com a comunidade, com as pessoas idosas, o que gerou um forte envolvimento com todas essas questões. Foram feitas reuniões com os mais velhos, os professores indígenas e os pesquisadores da universidade que passavam dias inteiros conversando. A escuta atenta aos problemas revelou porque na cosmovisão kaiowá-guarani o meio ambiente estava daquele jeito. Porque a vida deles estava difícil. Porque tinha acabado a mata. Porque o fogo comia tudo. O fogo entrava num canto da aldeia e saia no outro. Como ressaltou a professora não-indígena: "não tinha nada, era só sapé e braquiária. A maioria ficava sem casa porque o incêndio era muito grande".

Essa professora que acompanha desde 1997 o processo de construção da educação escolar em Te'ýikue reconheceu que: "para fazer um trabalho de recuperação ambiental, que é de longo prazo, exige-se mudança de comportamento, de envolvimento". Ela relembrou que quando Brand conheceu a área anos atrás disse que tinha muita erva-mate, muita mata e que era lindo o lugar. Em dez anos muito foi destruído: "tinha virado sapé e 
braquiária. Não tinha mais água. Água só nas voçorocas. Os poços sépticos estavam contaminados". Ela ressaltou que dentro de Te'ýikue existem cerca de sete nascentes:

todas as águas da aldeia nascem aqui dentro. É um privilégio. Aqui é um divisor de bacias hidrográficas. As nascentes daqui abastecem a bacia do rio Amambai. As que estão pro lado de lá da MS 280 vão pra bacia do rio Dourados. Alimentam duas bacias. As nascentes saem daqui sem contaminação.

$E$, seguiu descrevendo com emoção o processo de transformação a partir das intervenções que foram geradas: "a coisa mais bonita da gente ver foi que, na medida em que a gente foi cuidando das matas ciliares, das árvores de proteção das nascentes, a água foi aumentando de novo e onde tinha as voçorocas enormes fizeram as represas". Estas foram feitas com a finalidade de conter a voçoroca; de captar água para a comunidade tomar banho; de lavar roupa e, também, nelas se criavam peixes para ajudar na alimentação porque havia muita desnutrição.

Foi bastante dialogado o modelo da nova proposta de educação, se baseando no tripé: professores, lideranças e comunidade. Conforme Eliel Benites (2014, p. 81): "com a participação assídua da comunidade nas reuniões houve uma grande mudança na sua dinâmica interna, porque se tornou uma vivência contínua ouvir os "outros"”. A partir desta experiência: "a aldeia começou a se redescobrir, porque muitas demandas saíam destas discussões e redescobertas" (Idem).

As questões ambientais permearam todo o processo, envolvendo a escola com as crianças e a comunidade. A professora não-indígena falou com entusiasmo: "todo mundo era soldado de combate ao fogo pra não destruir as matinhas que a gente tinha plantado. $E$ o que aconteceu de mais bonito? As famílias que entenderam isso começaram a fazer a recuperação em torno da casa deles". Muitas matinhas foram ressurgindo no entorno das casas de muitas famílias. É o que pude verificar na região da Missão e de Mbopiy, conforme descreverei no tópico 3.3. O ciclo do desmatamento - braquiária - fogo - desmatamento ampliado foi rompido na medida em que contiveram o fogo e foram brotando as arvorezinhas.

A professora não-indígena ressaltou o trabalho conjunto da escola com as crianças, os pais, a liderança e a comunidade sobre o combate ao fogo e o plantio de árvores. Para isso, muitas reuniões foram realizadas. E se colocavam fogo, havia denuncia e a liderança aplicava castigo. Assim, o meio ambiente foi sendo repovoado. Atrás da escola de ensino fundamental foram plantadas as primeiras mudas do viveiro onde cada aluno plantou uma muda com o seu nome e assumiu a responsabilidade de cuidar da mesma. Até os eucaliptos foram plantados pelos alunos em lugares de banhado, pois, eles crescem rápido e podem ser usados para atividades domésticas. 
A mesma professora falou sobre o que poderíamos chamar de um trabalho de história do ambiente, ou seja, a busca da identificação das espécies que no passado compunham o cenário paisagístico e natural de Te'ýikue:

Como saber o tipo de árvore que tinha aqui? Conversamos com os professores, os pesquisadores. Fizemos um trabalho com os alunos para eles conversarem com os mais velhos da família pra descobrir os tipos de árvores que tinham. Quem sabia escrever, vinha com as listinhas escritas nos caderninhos. Os que não sabiam, falavam os nomes em guarani. Traduzíamos. E corríamos atrás da semente ou muda dessas árvores pra trazer pra cá. Porque eram essas árvores que queríamos, que eram nativas.

Depois de identificadas as espécies, o desafio foi onde encontrá-las para, posteriormente, fazer sua reprodução. Um desses lugares foi a terra indígena de Pirakuá, onde a equipe de trabalho ia para lá nos meses de agosto e setembro, como destaca a professora não-indígena:

era a época de semente, íamos com professor, pesquisador, alunos maiores. Acampávamos por duas semanas com duas caminhonetes. Durante o dia a gente ía garimpar as sementes. Voltávamos cheios de carrapato. Voltavam com as duas caminhonetes cheias de semente. Preparávamos, armazenávamos. Na sementeira. Tinha uma equipe muito atuante no viveiro. Tinha técnico agrícola. Tinha planejamento de coleta de semente, produção de muda, depois escoar essa muda pro meio ambiente.

As transformações do projeto de educação escolar indígena andaram de mãos dadas com o projeto de recuperação ambiental e com a solução de alguns problemas da comunidade. Como ressaltou a professora não-indígena: "a escola aqui é uma escola da comunidade". Reconheceu que: "a gente errou muito, mas errou junto com eles. E acertou e acertou junto também".

Com o plantio das mudas feitas no viveiro, foram realizadas as recuperações: da área atrás da escola; da mata ciliar das nascentes da unidade experimental e da microbacia. Conforme relembrou a professora não-indígena: "foi formando tudo. Pensa nas coisas bonitas que foi virando. Lá pra dentro eles fizeram corredor ecológico, tinha resquício de mata de um lado e do outro, mas os bichinhos não sabiam como passar. Eles plantaram as mudinhas e fizeram a ligação". Os alunos também incorporaram a defesa da mata. Ela relatou:

se você derrubar alguma árvore aqui no bosque da escola, os alunos pulam na tua cara. Teve que tirar umas árvores nativas pra construir a escola. Houve protesto. Agora fazemos reunião com eles e explicamos tudo. Algumas árvores tiramos com retroescavadeira e plantamos em outro lugar, ou fazemos mudas pra repor. Até com o eucalipto ocorre isso. Já incorporaram. Mas sinto que nos últimos anos tá enfraquecendo isso.

O grande desafio continua sendo manter as matas recuperadas longe do fogo. As árvores dos replantios são mais finas e queimam mais facilmente. Os aceiros constituem uma estratégia importante para prevenir e controlar as queimadas. Mas hoje em dia devido às dificuldades técnicas e de recursos financeiros, segundo a professora não-indígena, os 
moradores de Te'ýikue: "só ficam correndo atrás quando o fogo já vem. A gente não tem uma equipe que fizesse o planejamento mais amplo e que antecedesse as atividades. Diálogo tem, mas é difícil de fluir as coisas. É a ação".

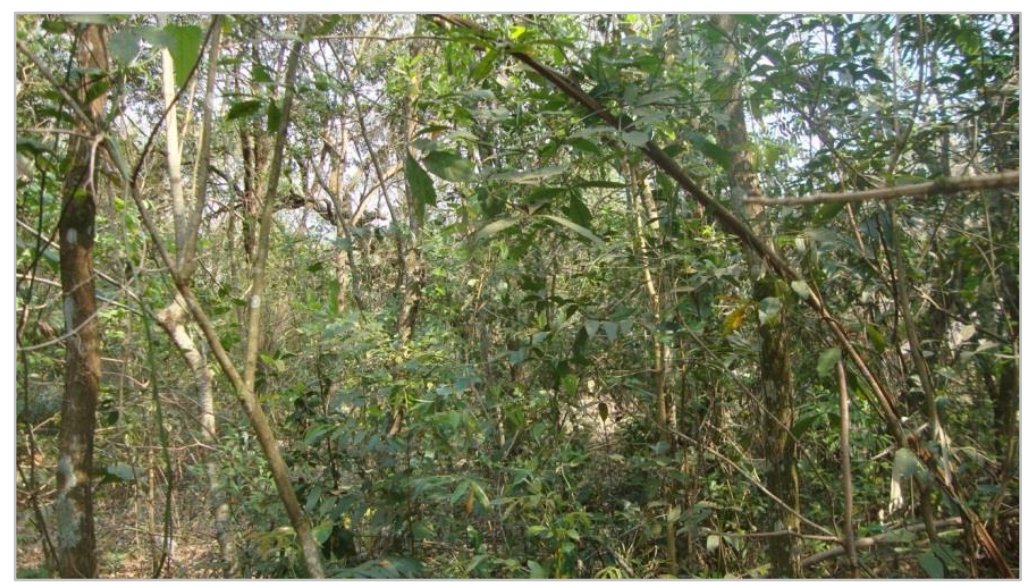

Fotografia 5 - Mata replantada atrás da Escola Ñandejara. Fonte: Autoria própria.

O uso do fogo e as queimadas eram e continuam sendo uma das grandes preocupações nas terras indígenas. De elemento tradicional nas práticas de agricultura em um tempo de condições ambientais mais estáveis a ameaça em tempos de braquiária e colonião. Com a perda das matas e substituição por essas espécies invasoras a paisagem nas terras indígenas foi paulatinamente se modificando. A estratégia imediata mais utilizada para limpar a terra para fazer as roças é promover a queima, que geralmente não tem controle, e acaba se espalhando por outras áreas, inclusive aos poucos remanescentes de florestas nativa ou secundária.

Em Te'ýikue, a grande preocupação é que o fogo não avance sobre as áreas de mata que foram recuperadas através dos projetos ambientais, além das áreas nativas ainda existentes. Daí o trabalho de diálogo para evitar a queimada que foi feito na comunidade concomitantemente com os replantios. Segundo a professora indígena:

a gente fazia reunião na comunidade primeiro por escolas, depois por região que era importante ter o mato, coisa boa que ele traz pra gente, e a questão do fogo também. Na escola, aquele espaço foi gradeado e foram plantados plantinhas. Aí cada sala adotava uma planta desde pequenininha. E naquelas planta colocava o nome dos aluno. A turma da manhã e a turma da tarde. De manhã molhava e a turma da tarde cuidava. Cada um foi cuidando da sua plantinha. Hoje lá, praticamente é como se fosse agroecologia. Tem inúmeras plantas alí atrás. $E$ também foi feito trabalho na comunidade, com as famílias. Cada um cuidar do seu mato, do fogo. Qualquer coisa quando via cobra no mato, botava fogo, aí depois diminuiu.

A resposta mais adotada para o uso do fogo reside na justificativa de fazer roça, ou seja, para limpar o terreno da braquiária/colonião. Estas, também atraem animais como 
cobras, então o fogo é usado para afastá-los. Já houve treinamento do corpo de bombeiros de Dourados e alguns indígenas foram treinados para atuar diante das queimadas.

A utilização do fogo pelos kaiowá é uma importante técnica de manejo na agricultura praticada imemorialmente. O sistema roça-queima-plantio é praticado por diversas culturas indígenas na América. Em espaços onde o acesso à terra e a floresta/mata ocorria em condições adequadas de suporte de regeneração da natureza esse sistema parecia funcionar de modo adequado. No entanto, a falta de terra para a demografia de terras indígenas demarcadas e para as poucas matas existentes tornaram inviável a prática cultural da queima.

Em todas as terras pesquisadas, o uso do fogo para preparar a roça e para combater as espécies exóticas (colonião e braquiária) põem em risco as poucas áreas florestadas existentes, gerando riscos de incêndios de grande proporção. A imagem de fumaça nas terras indígenas é uma presença constante, principalmente, no mês de agosto.

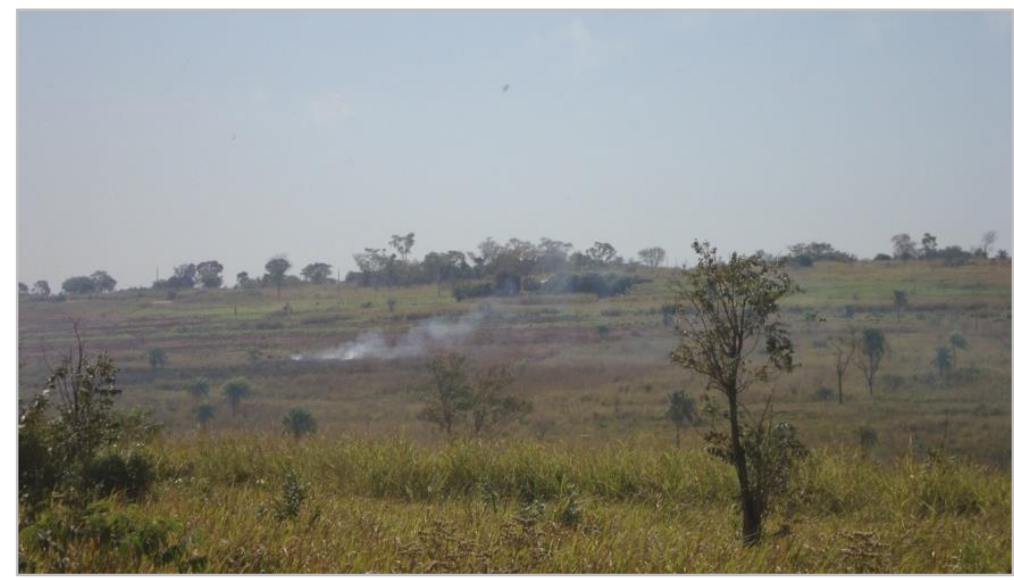

Fotografia 6 - Queimada em Te'ýikue Fonte: Autoria própria.

Voltando as questões da educação, na construção de metodologias, destacaram-se as figuras do professor-aluno pesquisador e interventor na comunidade, com o envolvimento das famílias. Optou-se pela utilização de temas geradores (temas de pesquisa e não de disciplinas pré-estabelecidas) a partir das realidades vivenciadas em Te'ýikue e a realização de planos de aula construídos coletivamente.

Sobre a formação dos professores, a maioria deles passou por processos de educação formal que os distanciou dos saberes da sua cultura. Com a criação de um magistério específico, chamado de Ará Verá, buscou-se fazer a ponte entre as diversas situações interétnicas vivenciadas por eles e o seu saber tradicional. Por isso, a fonte desse conhecimento situou-se na valorização dos idosos e rezadores. Era necessário nutrir-se 
desse saber, transformar-se como sujeito no papel de professor para trabalhar a educação escolar das novas gerações.

Eliel Benites, que nasceu em Te'ýikue, foi aluno das primeiras turmas do Ará Verá e do Teko Arandu e, também professor na sua terra, fala das dificuldades, mas também do clima de encantamento no processo de construção da escola e do momento que a comunidade passou a viver: "os professores indígenas jovens sentiam muita responsabilidade neste processo, porque assumiam uma postura de líderes antes do tempo. O diálogo com os mestres tradicionais, no primeiro momento, foi doloroso, porque precisávamos nos reconciliar com eles" (BENITES, 2014, p. 88). Mas, "aos poucos foi criado um clima de encantamento no processo de construção da educação escolar indígena, na Reserva Indígena Te'ýikue" (Idem).

A configuração atual das unidades escolares em Te'ýikue são as seguintes: no ensino fundamental: a Escola Municipal Indígena Ñandejara Pólo e suas extensões em Saverá; no Mbokajá e na região da Missão, chamada de Loide Bonfim Andrade. Devido à demanda pela continuação dos estudos foi inaugurada a Escola estadual de ensino médio Yvy Poty Flor da Terra.

A Escola de Ensino Médio iniciou suas atividades em 2006. São, aproximadamente, cento e trinta e oito alunos no ensino médio e trezentos e nove no EJA. A maioria dos professores não é indígena, diferentemente, do que ocorre na escola Ñandejara e nas suas extensões. No ensino médio, as aulas em guarani só são ministradas pelos professores indígenas. Há uma expectativa de ampliação dos professores indígenas devido à formação do Teko Arandu.

Segundo o diretor da escola Yvy Poty: "o intuito era de trabalhar com o jovem a questão ambiental. Através de aula integral em 2006 em que os alunos estudavam de manhã e a tarde tinham aula prática. Plantavam árvores nas nascentes e trabalhavam na roça coletiva com mandioca e outras plantações". Mas em 2008, a secretaria de educação não permitiu algumas atividades porque não tinha laboratório e biblioteca.

No ensino médio as disciplinas de geografia e biologia trabalham mais as questões ambientais. O diretor identificou que o maior problema da reserva são as queimadas. $\mathrm{Na}$ região do Mbokaja eles plantaram umas cem mudas, cuidaram, mas depois veio o fogo. Ele reconheceu que: "mesmo assim, melhorou um pouco com o trabalho da escola. Os alunos levam mudas do viveiro pra casa também. Tem famílias que cuidam bem do seu mato". Sobre a questão do lixo, os professores estão pensando em fazer um ponto de coleta em cada escola para o caminhão da prefeitura passar. O carro do lixo passa uma vez por semana em cada escola. No nível familiar, cada um cuida do seu lixo, mas a maioria o queima. 
O sonho da escola é oferecer um Curso Técnico em Agroecologia. A estrutura física dos laboratórios já existe, mas faltam equipamentos. Com esse curso, segundo o diretor, a ideia seria: "montar pequenos negócios pra os alunos permanecerem aqui. A maioria do pessoal daqui planta mandioca, mas não tem um esquema pra vender pra fora. Os que vem comprar, paga pouco. Com cooperativa seria uma possibilidade de vender sem atravessador". A criação de pequenos animais, como frango, seria outra possibilidade, assim como a venda de ovos. Ele disse que assentado e quilombola tem apoio, mas para indígena é mais difícil.

O diretor pontuou que a maioria dos alunos egressos vai trabalhar fora da reserva, principalmente, nas usinas. Uns procuram cursos técnicos, outros a universidade. A minoria segue estudando. Com o curso de Agroecologia, poderiam ser abertas possibilidades de trabalho na reserva. É difícil encontrar trabalho fora de lá. Atualmente, a maioria dos trabalhos internos é ocupada por indígenas, mas não se absorve toda a quantidade de alunos formados.

Os alunos chegam ao ensino médio com uma experiência de vivências ambientais na Unidade Experimental através das atividades do ensino fundamental, mas no ensino médio não há atividades na unidade. Existe certa descontinuidade dessa experiência. Hoje tem uma horta na escola, pelo Pronatec. De acordo com seu diretor: "se a gente tiver o curso de agroecologia vai trabalhar mais a questão ambiental e de sustentabilidade. Esse curso teria a duração de três anos. Nesse espaço, funcionaria a escola de ensino médio e o curso técnico, que pode ser integral, concomitante e subsequente". Segundo ele, a comunidade optou pelo modelo concomitante e subsequente. Ressaltou ainda, que "o conhecimento tradicional tem que vir com o conhecimento técnico. Tem que sempre caminhar junto".

O diretor lembrou que quando tinha uns sete anos presenciava queimada na mata para fazer coivara. Mas, "hoje não faz mais coivara. Porque não existe mais mato. Com o trator se evita mais a queimada. Tem que ensinar a plantar. $O$ jovem de hoje não gosta mais de plantar. Eu sou da geração de 80 , nasci em 82, eu não tenho roça”. Diferentemente do seu pai que tem roça, mandiocal e planta arroz. Seu pai foi uma das principais lideranças da reserva e fazia reza tradicional, guachiré e festa do milho. Mas, se converteu em evangélico.

$\mathrm{Na}$ visão do diretor, a escola do ensino médio deve dialogar com os mestres tradicionais. E alguns deles cobram, mas "ele acha isso certo porque tem professor de mestrado que cobra pra dar palestra, então eles tem que receber pelo conhecimento deles". Às vezes, ele faz uma cesta e entrega para os rezadores. Porque no ensino das práticas culturais: "o rezador vai passar a prática. O professor, a teoria". O diretor comenta que foi feita uma pesquisa na escola e descobriu-se que oitenta e sete alunos de cento e cinco são evangélicos. Por isso, "é difícil trabalhar práticas culturais no nosso modo de ser. Tem 
evangélico que proíbe tudo. Diz que é demônio, do satanás. A questão, educação indígena é complicada".

Percebi que as questões ambientais são trabalhadas na prática, de forma mais integrada, no ensino fundamental. No ensino médio não há projeto específico, algumas disciplinas trabalham conteúdos e ações pontuais. Estão à espera do curso técnico em Agroecologia.

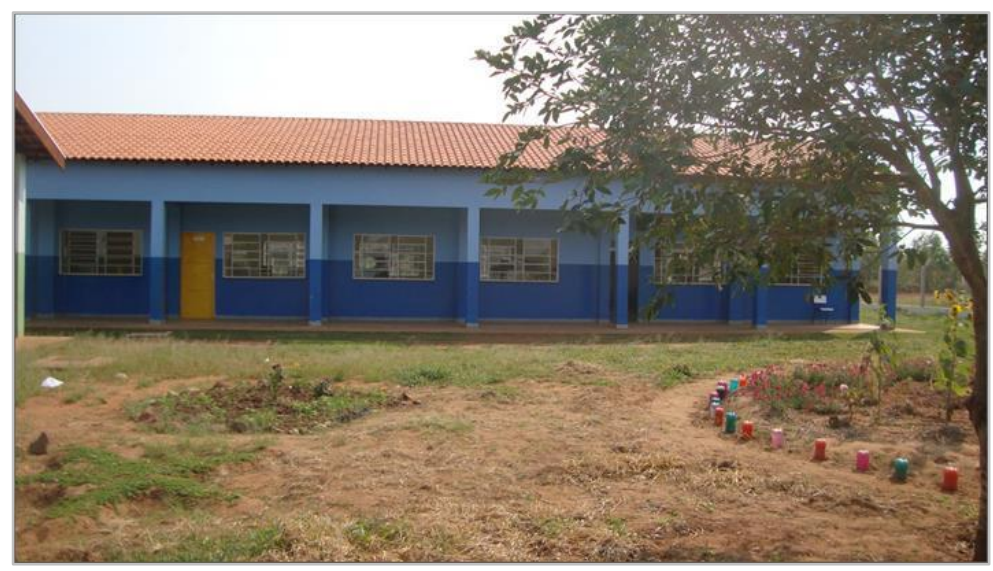

Fotografia 7 - Escola de Ensino Médio - Flor da Terra. Fonte: Autoria própria.

A partir de 1997 passou a ser constituído um Fórum de discussões sobre questões da comunidade, articulado a partir das escolas. Desde então, esse fórum ocorre sistematicamente a cada mês de abril, na semana dos povos indígenas. Segundo, Eliel Benites (2014, p. 95), "este trabalho coletivo dos Fóruns lembra como era nossa vivência tradicional no Tekoha Guasu no passado, onde todos se envolviam para realizar festas e cerimônias religiosas, cada um realizava as ações para um objetivo comum". A professora indígena reconheceu que:

\begin{abstract}
todas as conquistas até hoje é devido ao Fórum. Em abril, fazemos reuniões nas escolas para coletar sugestões para o Fórum. Depois, junta tudo e faz um grandão que é na última semana de abril, onde fazemos a Assembleia grande e chamamos as autoridades, aí entregamos os documentos pra eles. Tudo por meio desse Fórum e que temos os avanços daqui. Aqui apesar de ter problema interno na comunidade, mas nós conseguimos trabalhando tudo em parceria. Muitas das outras aldeias que tem esse problema, cada um trabalha no seu cantinho: educação pra lá, saúde pra cá. E aqui não. A gente tenta trabalhar junto.
\end{abstract}

Em relação às demais terras indígenas com população kaiowá e guarani de MS, Te'ýikue atraiu uma série de projetos e possui um número considerável de professores indígenas que atendem as escolas da sua terra. Sua experiência escolar indígena é paradigmática, assim como o projeto de recuperação ambiental. Conforme atesta Cariaga (2012, p. 106), "desde a década de 1990, Te'ýikue tem sido uma das áreas mais procuradas para realização de muitos projetos de pesquisa, que contam com financiamento". 
A formação de professores está associada ao cumprimento das normativas pósConstituição de 1988 por uma educação indígena específica, diferenciada e de qualidade e também aos movimentos políticos da Aty Guasu e do Movimento dos Professores Kaiowá e Guarani.

Em 1999 houve a implantação do curso de formação específica para professores em nível médio Kaiowá e Guarani, chamado Ára Verá (Tempo lluminado) através da Secretaria de Educação de MS em parceria com as prefeituras dos municípios que tem população kaiowá e guarani. Também foram parceiros desse processo: a UCDB, pelo Projeto KaiowáGuarani; a UFMS; a Diocese de Dourados e o Movimento dos Professores Kaiowá e Guarani. O Projeto Rede de saberes vem apoiando a permanência de indígenas no ensino superior nas seguintes universidades de MS: UCDB, UEMS, UFGD e UFMS. Está ligado ao projeto em nível nacional chamado Trilhas do Conhecimento, financiado pela Fundação Ford.

O trabalho de construção de materiais didáticos próprios a partir da realidade vivenciada pelos alunos (futuros professores) de cada terra, também se constituiu como uma ferramenta pedagógica importante para o ensino diferenciado. É o que atesta a feitura das representações cartográficas das suas terras realizado no ambiente do Ára Verá.

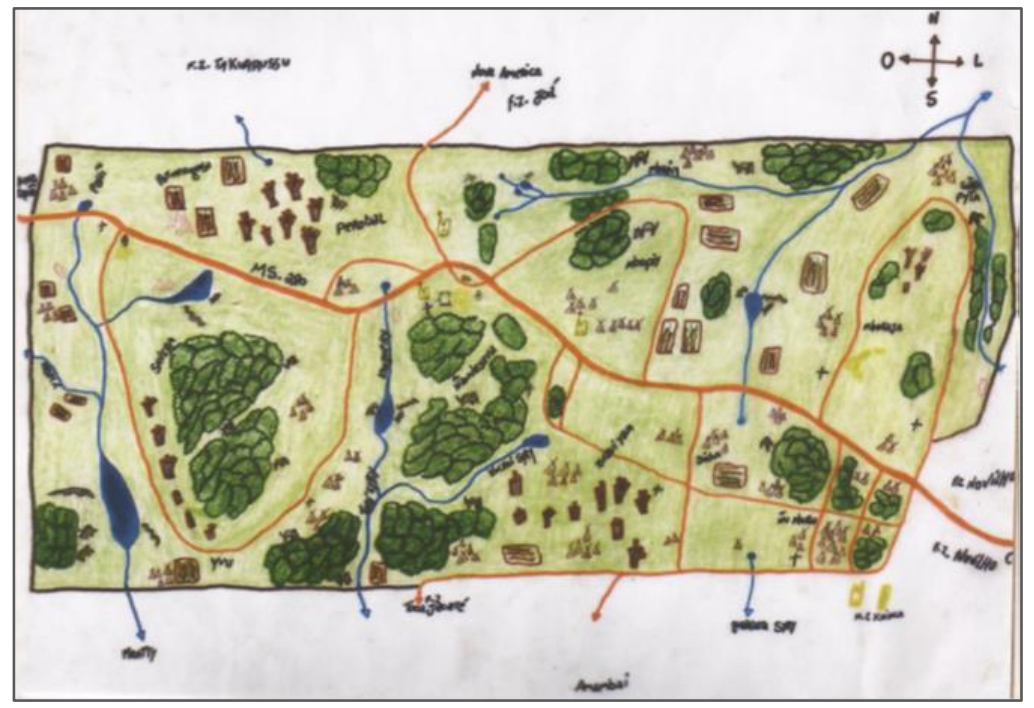

Croqui 1 - Cartografia étnica de Te'ýikue.

Fonte: GUARANI HÁ KAIOWÁ, 2011, p. 86.

Quando terminou a primeira turma do Ára Verá foi iniciada a discussão de um curso superior de licenciatura diferenciada. Foram alguns anos de discussão, iniciada no âmbito 
da UEMS, mas depois assumida pela UFGD onde ocorreu a criação da licenciatura específica chamada de Teko Arandu, atualmente na Faculdade Indígena ${ }^{88}$ (FAIND).

A formação dos professores indígenas através de cursos de formação específicos e da ampliação do acesso à universidade no Brasil fez com que houvesse uma ampliação da categoria desses professores e do que se poderia chamar de intelectualidade indígena, tema bastante discutido nacional e internacionalmente. Conforme atesta Lima (2013, p. 245):

\begin{abstract}
Essa intelectualidade indígena militante em surgimento e consolidação vem formulando concepções que partem de seu aprendizado - distributivamente variado - em suas tradições e do que tais tradições propiciam como chaves de leituras das intervenções de Estado em seus modos de vida, nos contextos locais e regionais específicos de seus povos no presente. Muito dessa reflexão vem sendo cunhada na militância e hoje em espaços acadêmicos de graduação e pós-graduação.
\end{abstract}

Este processo de formação de professores, de constituição de licenciaturas específicas e da construção da própria escola indígena não é imune a críticas. As principais delas residem nos dilemas entre a educação das famílias e da escola; nas dificuldades de se fazer o diálogo entre saberes indígenas e não-indígenas; na formação do professor; na construção de uma educação que seja realmente específica, diferenciada e de qualidade e na construção da categoria professor indígena.

Mesmo diante destas dificuldades, muito se tem refletido e construído no sentido de se romper com lógicas etnocentristas para se fazer uma educação que seja libertadora e apresente caminhos para as novas gerações. $O$ fato é que a escola tem exercido uma certa centralidade na vida das crianças e das famílias, bem diferente do modo de vida tradicional ideal kaiowá, pois, "a partir da escola desdobram-se muitas ações articuladas a fim de garantirem a ocupação do tempo das crianças, no enfrentamento à violência e como ações que possam "transmitir valores da cultura" para as novas gerações" (CARIAGA, 2012, p. 160). Em Te'ýikue, essa centralidade da escola na vida da comunidade "se tornou a estratégia política que busca assegurar a organização interna, diante dos novos problemas, inclusive das questões das quais as famílias dizem que "a cultura não dá conta"” (Idem, p. 165).

\title{
3.2.2 Renascimento da terra
}

Em 1996 começou a ser desenvolvido: "um amplo programa, de caráter interdisciplinar e interinstitucional, de pesquisa e de ações de apoio aos índios Kaiowá e Guarani no Mato Grosso do Sul, denominado Programa Kaiowá/Guarani” (UCDB, 2002, p. 1). Programa que

\footnotetext{
${ }^{88} \mathrm{O}$ Curso oferece Licenciatura plena em Educação Intercultural, com habilitações em quatro áreas de conhecimento: Ciências Humanas, Linguagens, Matemática e Ciências da Natureza.
} 
foi coordenado por Antonio Brand da UCDB através do NEPPI e da Diocese de Dourados em parceria com a prefeitura municipal de Caarapó.

A partir desse programa houve um amplo processo de transformações na escola e na comunidade, no sentido de construção de uma educação diferenciada de qualidade e de uma série de ações dirigidas à recuperação ambiental, produção de alimentos, a saúde preventiva e a história e sociedade Kaiowá e Guarani. O sub-programa de Educação Indígena Diferenciada auxiliou na implantação do curso de Magistério Específico, chamado Ára Verá para formação de professores indígenas da educação fundamental.

Já o sub-programa de Recuperação Ambiental e Produção de Alimentos baseou-se em várias ações como: a recuperação de duas represas e a construção de mais quatro; a criação de um viveiro de mudas; a recuperação da Microbacia de Jakairá; a implantação de Unidades de Pesquisa e Produção de Alimentos e Artesanato (UCDB, 2002, p. 4). E, teve como objetivo:

o estudo do território, recursos naturais e sustentabilidade e processo de comprometimento dos recursos, decorrente do processo de confinamento, incluindo, ainda, o monitoramento da cobertura vegetal, mediante técnicas de sensoriamento remoto e geoprocessamento; recursos e práticas alimentares tradicionais e contemporâneas, plantas medicinais manipuladas pelos Kaiowá e Guarani" (Idem).

Para tal, foi criado um "Plano de Gestão Ambiental na área indígena de Caarapó". O diagnóstico identificou que a mata vinha desaparecendo e a água estava em parte comprometida; a caça, a pesca, a coleta de alimentos e os medicamentos praticamente inexistentes; o solo empobrecido e as queimadas eram constantes devido à presença de colonião (Idem, p. 17).

Foram muitos os desafios identificados para a proposta de gestão. A equipe percebeu que a maior parte deles seria de caráter antropológico e não técnico, como: a aplicação de etnoconhecimentos em práticas de manejo; a participação da comunidade indígena, principalmente, no que toca à prática da agricultura de coivara; o uso do fogo e adoção de novas tecnologias (Idem, p. 18).

Um dos objetivos do Plano foi: "incentivar o envolvimento da comunidade indígena Kaiowá e Guarani com os ecossistemas locais, fortalecendo e expandindo os seus laços sociais, econômico, culturais, espirituais e ecológicos, objetivando a busca da sustentabilidade de forma integral, em todas essas dimensões" (UCDB, 2002, p. 20). Visou também estimular: "a implantação de culturas permanentes consorciadas com as culturas temporárias, viabilizando as chamadas "capoeiras melhoradas", áreas de roça que poderão se transformar em pomares e bosques, mediante os devidos tratos culturais" (Idem).

E, na questão de plantios, levar em consideração: "a dinâmica da sucessão natural, o tempo e o extrato que as plantas ocupam, o adensamento de plantas, o sombreamento, as 
podas para "rejuvenescimento", consórcios adequados, o aumento de massa orgânica, uso de adubação verde e de controles fitossanitários" (Idem). O plano de gestão ambiental está representado no mapa a seguir.

Passarei a descrever os projetos relacionados mais diretamente com as chamadas "questões ambientais e de sustentabilidade", juntamente com as falas de professores e dos atuais cuidadores do viveiro. Eles foram sendo construídos e executados através de diversos processos a partir de 1996, tendo sido articulados a partir desse Plano de Gestão Ambiental de 2002, com base nos diálogos com a escola, as famílias, a comunidade e o apoio de parceiros externos.

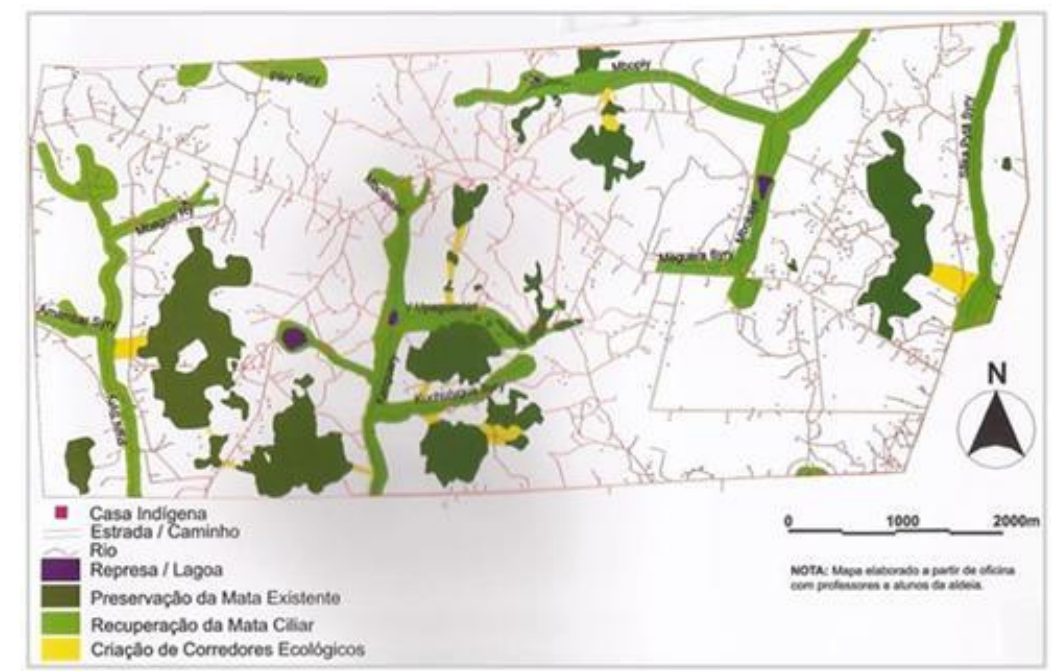

Mapa 4 - A aldeia que queremos.

Fonte: UCDB, 2009.

O Viveiro de Mudas está situado ao lado da escola Ñandejara. Nele, "foi criado um banco de dados fenológico onde encontram-se elencadas as espécies que compõem as fitofisionomias ocorrentes na região da Reserva de Caarapó e seu entorno" (UCDB, 2002, p. 27). Funciona também como centro de aprendizagem e prática de educação ambiental. Através dele, foram fornecidas mudas para que as famílias recuperassem o entorno das suas habitações com árvores, principalmente frutíferas, o que foi chamado de Projeto de Fundo de Quintais.

São quatro servidores indígenas que trabalham no viveiro. Destes, conversei com três. O mais antigo deles, o servidor 1, fica mais tempo lá e faz a germinação, o transplante e o plantio. Já o servidor 2 trabalha há onze anos no viveiro. Ele esclareceu que hoje em dia tem poucas sementes. A procura de sementes ocorre em vários lugares, como: nas matas de Te'ýikue; em algumas fazendas, como no Campanário, em que o proprietário permite a entrada e coleta e, na área urbana de Caarapó, onde tem jatobá, ingá e cedro. A equipe do viveiro possui um conhecimento sobre como fazer a coleta e as mudas. Como disse o 
servidor 2: "a gente já tem a manha, então já coleta. Em agosto e setembro é pra coleta de sementes". E prosseguiu: "dependendo da semente a gente já coloca na estufa ou direto no saquinho. Que nem jatobá vai direto pro saquinho. Tem outra que tem que colocar na estufa e começa a germinar".

Em alguns canteiros, adotou-se a técnica do plantio consorciado, onde, por exemplo, no segundo canteiro se encontravam pés de angico, jabuticaba, ipê roxo e mamão. Todos misturados. E, também, fruta do conde, guabiroba, cereja e jequitibá. São quase oito canteiros. Podem ser encontrados: ingá, canafístula, poncãn, jambo e tubercúlos. As hortaliças, como tomate e abóbora, são consumidas pelos servidores do viveiro e suas famílias. Lá são cultivadas mudas de eucalipto. As famílias que moram em Te'ýikue podem receber as mudas. Segundo o servidor 2: "tem família que leva de quinze a vinte muda. Agora tão incentivando o pessoal aí. Fizemos reunião. Tem família que não tem nenhum pé de sombra na casa". Mas depois que as famílias levam as mudas, a responsabilidade de cuidar é delas.

O servidor 3 trabalha no viveiro há cerca de onze anos. Ele se referiu à época em que o pessoal da UCDB estava junto com eles e da existência de recurso. Por isso, conseguiram fazer o viveiro e um trabalho preventivo das queimadas, pois, se fazia aceiro através do uso de trator e tinha combustível disponível. Agora ele reclama que: "acabou. Não tem mais estrutura adequada pra trabalhar. Semente tá meio parado. Nós sempre planta na beira dos açudes, na represa. Por três vezes, nós plantemos na nascente alí em baixo, mas o fogo vai lá".

O servidor 1 conhecia muitas árvores nativas de lá. Ele é um dos pioneiros do trabalho no viveiro. Afirmou que existem "quarenta e oito variedades de árvores. Tem aroeira, peroba rosa, jequitibá, canafístula, cedro". Pelo projeto de recuperação, ele descreveu que depois que as mudas se formaram, eles começaram a plantar na escola e na microbacia, onde existia muita braquiária. Ele mostrou algumas árvores por trás da escola que já estão grandes, mas que levaram quinze anos para atingir aquela altura. $O$ servidor 3 disse que atualmente a escola está sem projeto de replantio, mas às vezes o pessoal do viveiro faz algumas ações pontuais.

Sobre as projeções do "A aldeia que queremos" (Mapa 4), o servidor 3 disse que "o projeto do corredor ecológico não avançou muito". O local onde tem mais mato hoje em dia são nas regiões de Mbopiy e Yvu. Sobre o controle das queimadas ele disse que está difícil controlar atualmente. Na sua fala: "nós tinha falado com a prefeitura pra arranjar 200 litros de óleo por mês pra fazer aceiro. Mas o nosso trator tá quebrado. Tá parado. Foi trator do projeto da UCDB. Mas tem problema pra conseguir combustível, manutenção". A comunidade também não está colaborando, segundo ele: "tem que fazer palestra. A gente começou a fazer no Mbopiy e na Missão e deu certo. Aí depois pararam". Perguntei como 
eram essas palestras, ele pontou que: "chegava, conversava com a comunidade. Falava a importância do matinho, de não queimar. O que a matinha faz". Isso acompanhado de alguns professores e da liderança. Mas "hoje a liderança tá parado, não se envolve muito nessas questões. O certo era fazer uma palestra bem feito com eles. A importância das matinhas".

Partimos para uma caminhada por trás da escola para observar a matinha, seguindo por uma trilha. O servidor 3 foi narrando as experiências que deram certo e as que não foram muito bem sucedidas. Mostrou umas mudinhas de aroeira que estão pequenas apesar de terem sido plantadas há mais de dez anos. Já teve muda de erva-mate, mas agora não há mais: "frutífera e erva-mate são as mudas que o pessoal pede mais". Eles tentaram fazer um sistema agroflorestal com frutíferas, como banana e abacaxi. Mas, segundo ele não deu certo, porque não cuidaram direito.

O servidor 1 quase não falou quando estávamos sentados no viveiro, mas quando fomos para mata ele se sentiu mais à vontade e conversou. Segundo ele, a própria mata, através do plantio de árvores acabou com a braquiária: "a sombra mata". Então, alguns animais voltaram pra lá, como jacú e tatu. Mas ele observou diferenças entre a mata nativa e a que foi replantada, porque: "a árvore plantada tá em fileirinha. E a nativa já não, parece que tem mais hábito, se habitua mais". Eles procuraram diversificar o plantio das espécies em uma mesma área. $\mathrm{E} o$ viveiro fornecia as sementes. As árvores nativas têm uma casca mais grossa. Onde era a mata nativa tem outras árvores que ficam próximas, o mato é fechado e na mata plantada é mais aberto.

Durante a caminhada, vimos uma árvore de cedro que estava muito raspada para fazer remédio. Na observação dos servidores, como quase ninguém sabe a reza, então tiram a casca de qualquer forma. O servidor 3 falou do projeto sobre quintais para plantar frutíferas, nos anos de 2003 e 2004, quando foram plantadas árvores em várias casas. Principalmente, poncã, tangerina, manga, banana e acerola. Muitas famílias participaram do projeto e têm nos seus quintais as frutíferas.

Sobre os corredores ecológicos ${ }^{89}$ previstos no plano de gestão, alguns conseguiram se formar, como o que está na Unidade Experimental, em Mboipaso, conforme atestou o professor da unidade. Foi prevista a recuperação da vegetação ciliar, "com base na

89 Corredores ecológicos são faixas contínuas de mata visando conectar fragmentos florestais isolados. "Atualmente, a proposta de implantação de corredores ecológicos vem sendo defendida como uma estratégia de gestão da paisagem, principalmente tendo em vista a manutenção e ampliação dos processos ecológicos e ambientais de fragmentos que concentram grande biodiversidade, mas isolados por atividades antrópicas" (ESAT-GT, 2012, p. 25). Segundo a definição prevista na Lei 9.985/00, art. $2^{\circ}$, XIX, sobre unidades de conservação, "são porções de ecossistemas naturais ou seminaturais, ligando unidades de conservação, que possibilitam entre elas o fluxo de genes e o movimento da biota, facilitando a dispersão de espécies e a recolonização de áreas degradadas, bem como a manutenção de populações que demandam para sua sobrevivência áreas com extensão maior do que aquela das unidades individuais". 
sucessão ecológica e utilização de mudas produzidas no próprio viveiro da Reserva" (UCDB, 2002, p. 24). Sendo "priorizados os locais com maior nível de degradação e aqueles que foram indicados como prioritários pela comunidade na elaboração do plano" (Idem). E, também, o reflorestamento para uso coletivo através de espécies de rápido crescimento, aproveitando vazios ou áreas degradadas. Para o uso de madeira e lenha para usos diversos, inclusive a construção e reparação de casas. É o caso da área central onde houve o plantio de eucalipto.

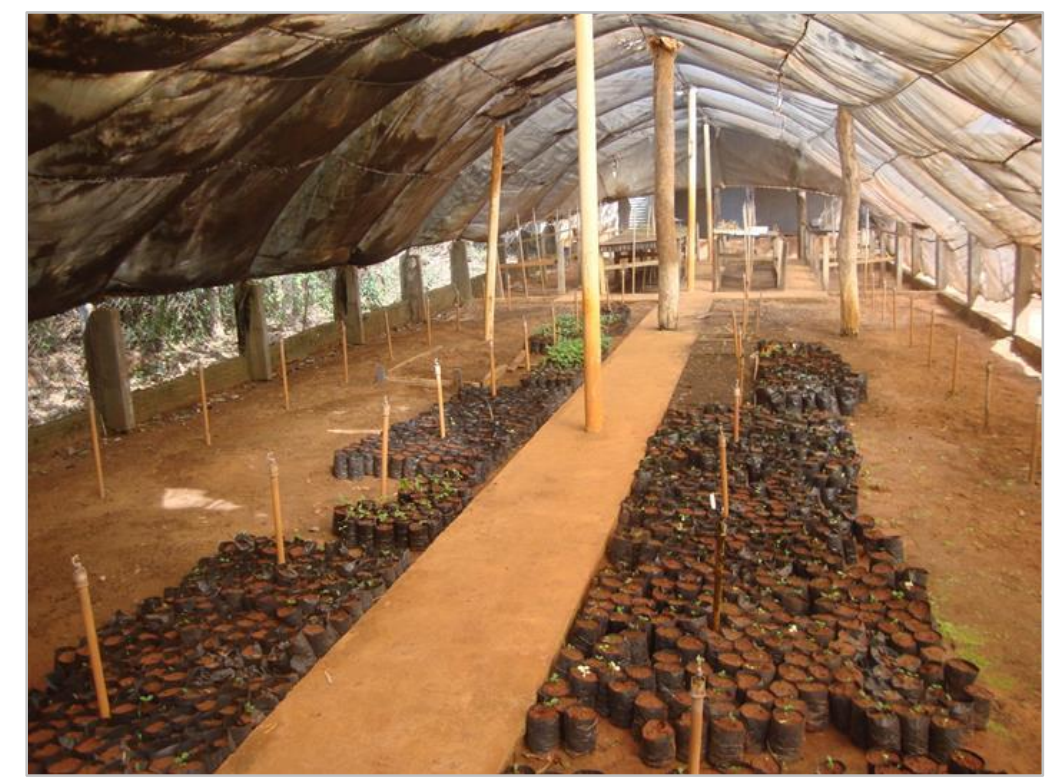

Fotografia 8 - Viveiro de mudas.

Fonte: Autoria própria.

Houve a construção de uma represa junto ao córrego Mbopey que visou à contenção de erosão ao longo desse córrego com a diminuição de assoreamento e também o aproveitamento de energia hidráulica através de bombeamento de rodas d'água, psicultura e lazer (UCDB, 2002, p. 26).

Foram feitos plantios de enriquecimento junto a fragmentos florestais visando favorecer a diversidade biológica e a ampliação da base genética de espécies (Idem, p. 26). Segundo Eliel Benites (2014, p. 120), "o plantio das árvores nativas tem por objetivo recuperar as nascentes, as microbacias, os corredores ecológicos, trazendo de volta os donos das matas (ka'aguy jára), dos animais, das plantas".

Na parte da educação, "os alunos começam a compreender que as árvores são como pessoas que estão morando na aldeia e que precisam ser respeitadas e valorizadas, num outro tipo de relação com o meio ambiente, constituindo um novo modo de ser kaiowá e guarani no processo de recuperação ambiental". (BENITES, 2014, p. 121). A educação ambiental foi considerada como algo central para a execução do Plano, entendida no seu: 
"caráter interdisciplinar, integrando a comunidade indígena, escolar, instituições e parceiros envolvidos, adequando conteúdo programático básico com atividades específicas quanto ao conhecimento cultural e tradicional sobre manejo e utilização dos recursos naturais". (UCDB, 2002, p. 28-9).

Ao mesmo tempo em que se deu um apoio ao desenvolvimento da agroecologia tendo como atividades: formar "agentes agroecológicos"; motivar os agricultores indígenas para a produção agroecológica; promover capacitação em agroecologia para os agricultores indígenas; ampliar as Unidades de pesquisa, produção de alimentos e artesanato; apoiar a produção de insumos alternativos (composto orgânico, biofertilizantes e defensivos alternativos); formar um banco de sementes de variedades agrícolas tradicionais, espécies nativas e adubos verdes; apoiar a implantação de sistemas agroflorestais (SAFs). (Idem, p. 30-6).

\title{
3.2.3 A unidade dos experimentos dialogados
}

O Projeto das Unidades de pesquisa, produção de alimentos e artesanato ou simplesmente "Unidades Experimentais" ou "Projeto Poty Reñoi" (o nascimento da flor) pretendeu, inicialmente, apoiar a permanência dos alunos na escola visando a minorar a evasão e a repetência. Iniciou-se em agosto de 2001 com as parcerias do Programa Kaiowá-Guarani da UCDB, da Prefeitura de Caarapó e de um órgão do Estado de MS, chamado IDATERRA (UCDB, 2002, p. 33-4). A professora não-indígena descreveu o que motivou a criação da Unidade Experimental:

\begin{abstract}
A juventude indígena, essas novas gerações se distanciou muito da cultura indígena. Historicamente, os Guarani-Kaiowá são pequenos agricultores. São coletores também. Mas sempre produziram as rocinhas deles de coivara pra se alimentar. E essa coisa foi acabando. O que acontece? Os homens vão pra usina, um trabalho doido, se matam lá, vem com dinheiro, vai pro mercado e compra até a mandioca já empacotadinha limpa. E aí essa meninada vai com quem pra roça? Vai aprender com quem? Ter que ter alguma coisa disso junto com a escola, né. Aqui quando os meninos tinham 12 anos pegavam registro de adulto e iam pra usina ganhar dinheiro e abandonavam a escola. Casava cedo. Era um desastre. Dificilmente um aluno de 14, 15 anos ficava na escola. Era o único jeito que eles enxergavam a vida aqui dentro. Como é que a gente faz pra reverter isso? Aí começamos. No governo do Estado foi estabelecida uma bolsa pra manter 0 aluno na escola. Eles ganhavam a bolsa com as atividades complementares da Unidade Experimental e atividades de artesanato, de esporte, informática e pesquisa bibliográfica e de campo, sobre cultura, natureza, plantas medicinais.
\end{abstract}

No início do projeto, eram setenta alunos e para mantê-los na escola havia o apoio de uma bolsa de $R \$ 70,00$ do Programa Bolsa Família do Governo do Estado, que começou com atividades de produção de alimentos. Após alguns anos, as bolsas não foram mais disponibilizadas e a identidade do projeto foi se transformando. Passou a ser visto como um 
espaço de vivência e foi adotando práticas de sistemas agroecológicos. Hoje em dia, atende alunos do ensino fundamental do $4^{0}$ ao $9^{\circ}$ ano e algumas famílias da comunidade. (BENITES, 2014, p. 104-117). A partir do 4ํano, o aluno vai para lá uma vez por semana fazer atividades. O Projeto é ligado a todas as extensões da escola Ñandejara. O objetivo específico definido no Projeto Político Pedagógico é:

fazer com que os alunos percebam a importância da terra dentro da cosmologia tradicional, através do cultivo, do manejo, do reflorestamento das plantas que oferecem alimentos e bem estar a sua família, realizar plantio de sementes tradicionais como forma de fortalecimento e manutenção das espécies nativas Guarani Kaiowá. (BENITES, 2014, p. 116).

A Unidade Experimental é como se fosse um laboratório da comunidade. Desde o início desempenha uma função pedagógica-escolar, visando à manutenção do aluno na escola e a aproximação deste com práticas e vivências culturais e de agricultura. A unidade utiliza técnicas de adubação orgânica, plantio consorciado, inseticida natural e manejo de ervas daninhas.

O apoio à agricultura das famílias também é uma atividade que faz parte das suas funções, variando no tempo o número de unidades familiares atendidas a depender da estrutura de apoio existente. Muitos parceiros não-indígenas contribuíram de diversas maneiras para sua concepção e desenvolvimento. Participações que foram desde o apoio para estrutura física à filosofia das técnicas a serem adotadas. A recuperação das nascentes, o renascimento da mata, a construção da represa, frutos do Projeto KaiowáGuarani foram importantíssimos para a criação de um ambiente adequado para o desenvolvimento das atividades e para o envolvimento dos alunos e das famílias.

A atitude reflexiva sobre as técnicas e alternativas de recuperação da natureza e da produção de alimentos guiou a condução de vários experimentos. A adoção da agricultura orgânica com aplicação de adubos verdes e inseticidas naturais reflete essa postura. Nesse sentido, o uso de sementes nativas e de sistemas consorciados e agroflorestais parecem se harmonizar com a cultura kaiowá-guarani aliando conhecimento tradicional e técnicas modernas de manejo.

A experiência da Unidade mostra as inúmeras possibilidades de criação e de desenvolvimentos das diversidades biológica e cultural. Ela revela como é rico, belo e possível conviver na e pela diversidade; como se pode unir diversas gerações com um mesmo propósito; como a cultura se transforma através de conhecimentos que se harmonizam; como os encontros e diálogos são estimulantes e inspiradores. A Unidade é um oásis de vida e de esperança para índios e não-indios.

O professor atual da unidade começou a trabalhar lá em 2011. Muitos professores trabalharam neste espaço. Sobre as atividades com os alunos do $4^{\circ}$ ao $9^{\circ}$ ano, o professor 
disse que o planejamento é de acordo com o nível da turma, em 1 h30 de atividades. $O$ tempo é utilizado para conversar e para as práticas.

Já com as famílias o trabalho é de orientação. Elas têm compromisso com o banco de sementes, ou seja, pegam, plantam e quando colhem, devolvem a mesma quantidade para alimentar o repositório de sementes e também repassam para outras famílias para tentar multiplicar o conhecimento. A produção agroecológica também é estimulada. A Unidade chegou a atender oitenta famílias, mas os professores viram que a dificuldade aumentou, então diminuiram para quarenta. Atualmente, são dez famílias que estão nesse projeto e os professores atuam bem próximos a elas, que também se comprometem a recuperar a área no entorno de suas casas.

O professor narrou que antes do reflorestamento da área da Unidade havia muita braquiária e o solo era muito pobre. Mas como há nascentes dos dois lados da área, começou a ocorrer o processo de transformação. Foram usadas técnicas de agroecologia, de adubação verde e de compostagem. Foi feito o minhocário, com minhoca californiana (trazidas por dois pesquisadores da Embrapa) que produz o húmus. O professor refletiu sobre as condições ambientais do passado e as existentes atualmente sobre o uso do fogo:

naquela época era árvore, mata. Aí plantava. Só que hoje isso não funciona mais. Hoje é capim, braquiária, colonião, sapé. E se você limpar com fogo, no dia seguinte já tá tudo brotando. Essa técnica que a gente tenta tirar. $\mathrm{E}$ colocar um novo. A realidade que a gente vive hoje mudou muito. $O$ espaço tá pequeno e muita gente. A gente tem que saber produzir no mesmo espaço sem prejudicar o meio ambiente e sem prejudicar a produção também. O uso do veneno, que isso seja evitado.

A principal ameaça ambiental da reserva segundo a visão do professor é o fogo:

Por que ele vai desmatando, destruindo, vai acabando com a variedade de espécie. Aí só nasce braquiária, colonião, sapé. O pessoal coloca mais fogo na braquiária. A mata chegava no terreiro. Mas como foram destruindo, aí ela não consegue se recuperar, aí a braquiária vai tomando conta. Aí fica mais fácil de queimar. Não tem o controle, eles não fazem o aceiro. Tem pessoas que botam fogo pra limpar o terreno, e outras pessoas veem uma cobra e já quer se livrar do mato.

Sobre as formas de combater a braquiária e o colonião, a orientação da Unidade é utilizar o adubo verde. Essas espécies não convivem bem com a braquiária conduzindo-a a um sufocamento. A Unidade orienta as famílias para usarem feijões, como mucuna e guandu, para combater a braquiária:

a mucuna sobe nas árvores, é trepadeira e sufoca mesmo. E o guandu é porque é uma árvore, arbusto e faz aquela sombra. Elas vão arando, arejando o solo e aí produz matéria orgânica. $E$ pro colonião é a mesma técnica. A gente pede pras famílias não botarem, fogo. Cortar o colonião, que a própria palha vai abafando a raiz. A gente fala do solo que a gente tem que deixar coberto. 
O professor da unidade, nascido e criado na reserva, concluiu o Teko Arandu e faz pós-graduação em educação na UFGD, revela um forte sentimento de pertença ao lugar. Sobre o seu papel na Unidade, revelou:

\begin{abstract}
a gente vai lutando pra mudar pelo menos um pouquinho. A gente quer se tornar independente. Porque viver na dependência é muito difícil. A maioria das famílias fica dependendo muito do governo. Espera semente, trator, combustível da Funai. A época não espera, vai passando. E as sementes que vem da Funai são de péssima qualidade. Aí a pessoa planta e acaba se decepcionando com o resultado.
\end{abstract}

$\mathrm{Na}$ casinha onde fica o depósito das sementes, o professor mostrou com entusiasmo, várias delas, como milho (de várias cores: branco, vermelho e mesclado, com seis espécies); feijão (com vinte e três espécies); amendoim; gergelim preto; arroz (de três espécies: bico preto, amarelão e agulhinha), dentre outras. A casca de arroz é utilizada para adubar o solo. Sobre a conservação das sementes, o professor disse: "antigamente, conservava em cima da fogueira, aí a fumaça não deixava o caruncho estragar a semente. Hoje a gente tá tentando guardar nas garrafas. Aqui você só pode abrir e plantar. Senão, entra e estraga". As famílias pegam para plantar, levando um saquinho ou uma garrafinha. Hoje em dia, o professor exerce, dentre muitas atribuições, o papel de guardião das sementes.

Sobre a irmã Lucinda ${ }^{90}$, falou com nostalgia do tempo em que ela trabalhava pela Unidade e do seu empenho em levar adiante o projeto com as sementes crioulas. Atualmente, poucos trabalham no projeto da unidade e está difícil levar algumas tarefas adiante. Tem apenas mais outro professor que trabalha na Unidade e contam com o apoio da APOEMS, que é a instituição mais presente atualmente. Há dois técnicos que vão lá, na última semana de cada mês.

Perguntei se as atividades que são realizadas na Unidade são chamadas de Educação Ambiental. O professor respondeu que sim, mas "na verdade, o índio não tem o hábito de classificar as coisas, de dividir. Ele vê o todo".

Lá são produzidos inseticidas orgânicos com diversas espécies e através de várias técnicas. Um deles é feito com cebolinha. Atualmente, a maior ameaça é a lagarta. Outros inseticidas naturais são o fumo, a pimenta e o nim (plantinha que segundo o professor é a melhor de todas).

As famílias apoiadas pela Unidade produzem mais para uso interno. São produtos sem agrotóxico. Segundo o professor, quem vem de fora, frequentemente, do município de Caarapó, para comprar quer pagar muito pouco. Em geral, são alimentos como mandioca,

\footnotetext{
${ }^{90} \mathrm{O}$ projeto das sementes nativas recebeu o apoio fundamental de irmã Lucinda. O professor fala sobre ela: "Aí no ano passado, infelizmente, morreu dona Lucinda. Ela foi uma perda muito grande porque ela era uma aposentada voluntária onde dava uma direção, um caminho pro pessoal da unidade. A gente tinha muito esse aval dela".
} 
abóbora e batata. A unidade tenta orientar para que não haja exploração. Em Te'ýikue não há feira para trocar produtos. Conforme o professor explica, pensaram em fazer isso, mas não deu muito certo. Na época do plantio há reunião. Eles trocam sementes, pois, confiam no trabalho da Unidade. As famílias pegam as sementes depois devolvem. A troca de excedentes ocorre, principalmente, entre os parentes.

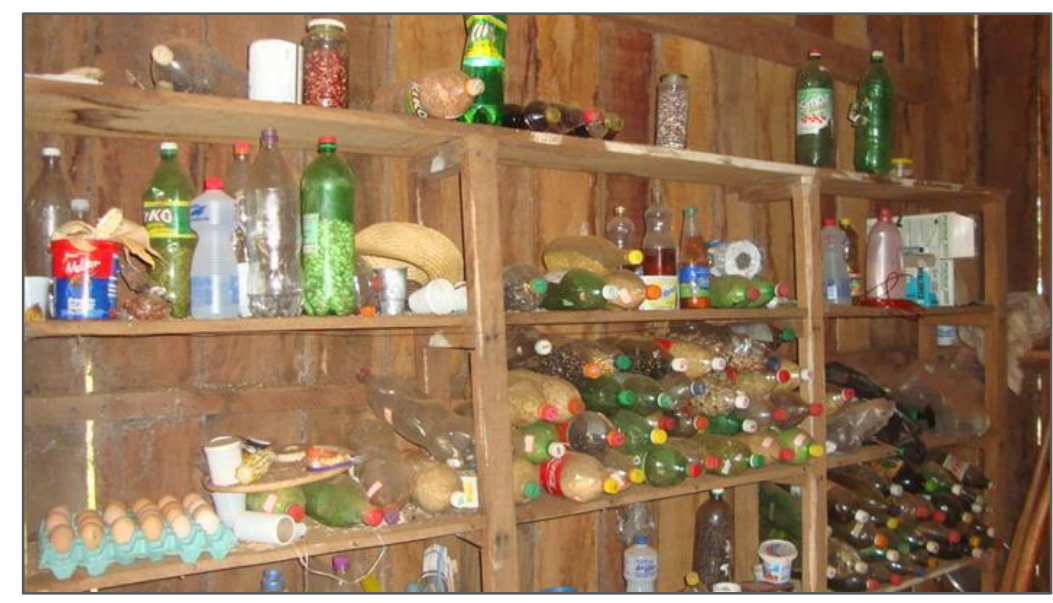

Fotografia 9 - Banco de Sementes. Fonte: Autoria própria.

$\mathrm{Na}$ nossa caminhada pela unidade, o professor foi apresentando: o minhocário, a criação de animais, a sementeira, a horta, as demais plantações, a mata, a nascente, a represa. A horta complementa a merenda da escola. A escola consome parte dos alimentos produzidos, mas ainda precisa complementar com os alimentos enviados pelo município.

Segundo o professor, a horta possui várias espécies, dentre elas a alface americana, roxa e crespa. O coentro é novidade, ninguém cultivava. Comer hortaliças não é da ancestralidade, mas eles estão tentando introduzir: "o alface é bem aceito. A cebolinha e salsa já não vai. Eles não gostam de coentro, beterraba, almeirão, jiló". Na verdade, ele acha que as verduras que não são bem aceitas deve-se ao fato de: "não saberem preparar ainda. Porque na escola, as cozinheiras colocam até a folha da beterraba no feijão e as crianças comem, sem saber". E, complementa: "o brócolis também, esse também tá sendo bem aceito na escola".

O professor mostra várias plantações em SAFE que estão dando certo. Uma delas é com banana, laranja, cará, milho e açafrão: "em volta das frutas, a gente planta o feijão de porco. As formigas não chegam nele e evita fungo. Faz um círculo". A Unidade tenta plantar consorciado $^{91}$. No sistema consorciado trabalham com duas ou três espécies, dependendo

\footnotetext{
91 "Aplicando o consórcio de espécies de distintas estaturas, a vegetação forma andares ou extratos, impedindo a incidência direta dos raios solares sobre o solo, o que provocaria a queima da matéria orgânica e a aceleração da volatização de determinados nutrientes. Em certos sentido, as espécies cultivadas imitam os processos que ocorrem na vegetação da floresta: plantas com distintos sistemas radiculares retiram nutrientes das diversas
} 
do que se vai plantar: "aí faz essa mistura, essa bagunça, como abacaxi com cana". Ele foi revelando que na natureza não existe uniformidade e, sim, diversidade ${ }^{92}$. A unidade faz ainda muda, como as de pimenta amarelinha ardida, pimentão e berinjela. Lá existe uma estufa pequena, então, quando é necessário expandir utilizam a estufa do viveiro que tem mais estrutura.

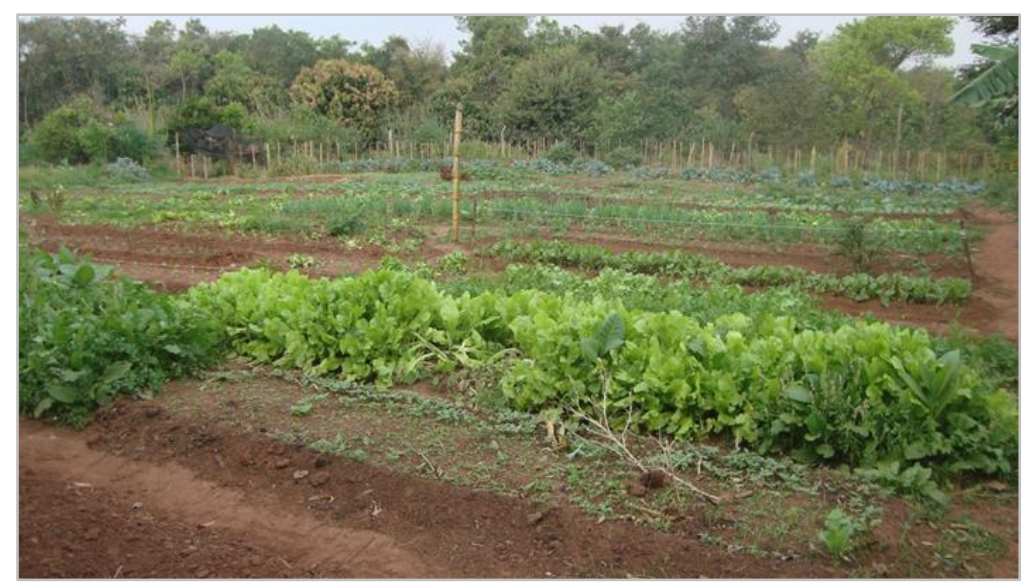

Fotografia 10 - Horta na Unidade. Fonte: Autoria própria.

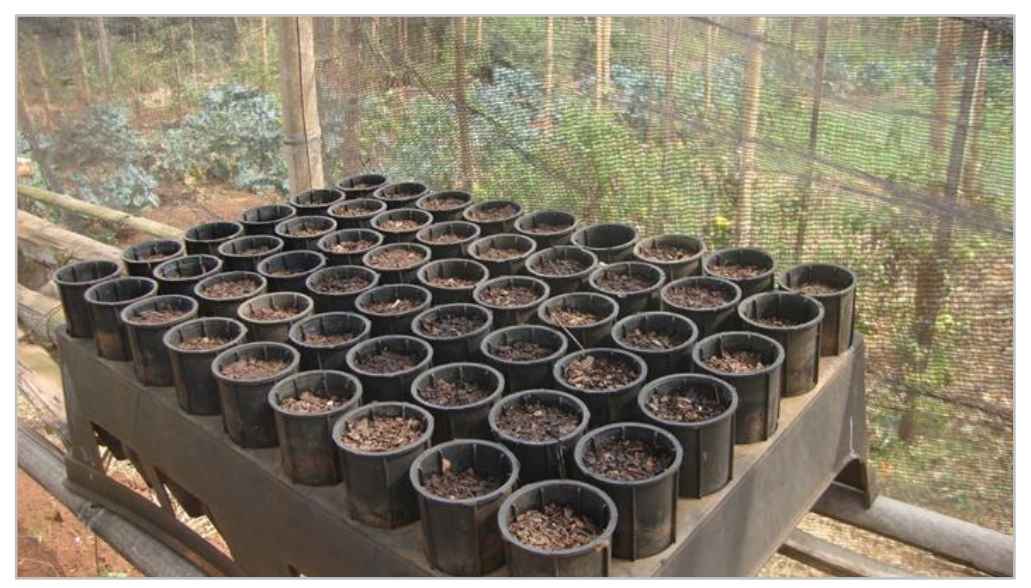

Fotografia 11 - Mudas da Unidade.

Fonte: Autoria própria.

\section{Ao chegarmos ao córrego que se chama Boypasso (o passo da cobra) o professor me} explicou sobre a recuperação da área. A matinha atrás foi do reflorestamento do projeto da

camadas do solo, realizando a sucção seletiva dos nutrientes de acordo com as necessidades de cada espécie. Isto possibilita o aproveitamento ótimo da água e dos nutrientes do solo. Por outro lado, os restos vegetais que permanecem sobre o solo (troncos, tocos e galhos) reduzem o impacto direto da água da chuva, reduzindo a incidência da erosão, principalmente quando se trata de solos porosos, sujeitos à lixiviação" (PEREIRA, 2004, p. 207-8).

${ }^{92}$ Existem diferenças significativas entre as formas de cultivo e o grau de utilização dos recursos naturais entre sistemas monoculturais e a agricultura nativa. Segundo Shiva $(2003,56-8)$, nas monoculturas há o predomínio da "integração de sementes e os produtos químicos", visando tornar uma cultura "extremamente produtiva" o que gera uma série de impactos ecológicos negativos. Na agricultura nativa prevalece uma "relação simbiótica entre solo, água, plantas e animais domésticos", em sistemas de "rotação de culturas" complexos e diversificados com insumos orgânicos. 
UCDB. O professor revelou que "Brand era apaixonado por esse lugar". A mata ciliar também foi replantio. A Área da Unidade Experimental tem 2.8 ha, excetuando a matinha.

Existe dificuldade de conscientizar as pessoas para não cortar a mata. Muitos precisam de madeira para fazer casa e/ou chiqueiro. Esta percepção também é compartilhada pela professora não-indígena que relembrou: "a Unidade é a microbacia recuperada. Alí não tinha nada. Há uns moradores novos que tão indo pra lá com foice e cortam onde reflorestamos com o apoio dos alunos e moradores antigos da área. Eles não sabem da história. Eu não vejo mais reunião da comunidade".

O professor mostrou o local onde é o encontro da mata atlântica com o cerrado, mas paramos no encontro das duas nascentes, onde se faz um "V" e conversamos com o barulhinho da água. Ele narrou que: "de vez em quando a molecada toma banho aqui e também pescam. Nosso trabalho é até aqui. O mais valioso é a mata. A gente trabalha com conscientização. Porque braquiária, colonião não serve pra nós". O encontro dos dois córregos foi recuperado com a matinha.

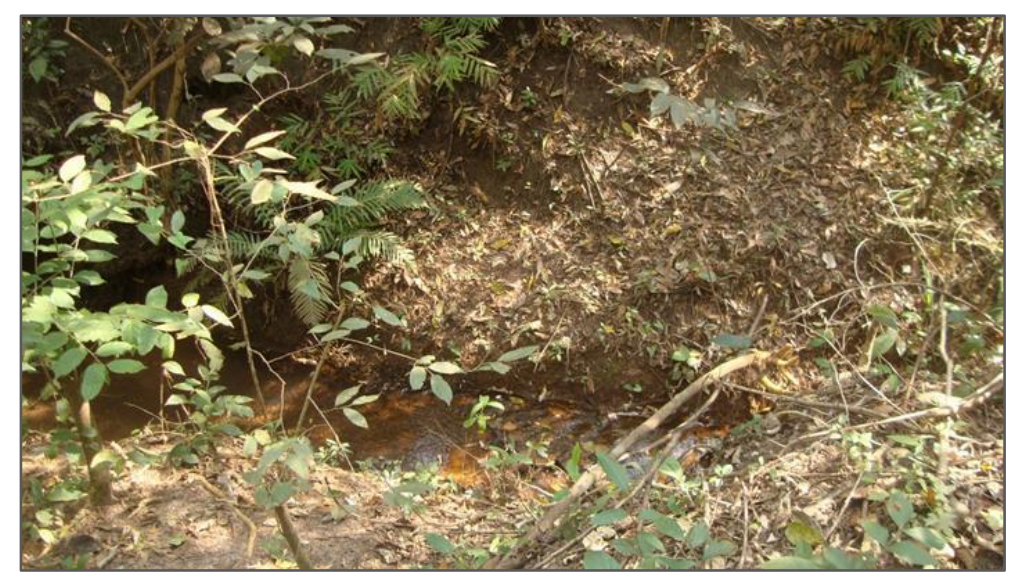

Fotografia 12 - Córrego na Unidade Experimental.

Fonte: Autoria própria.

No projeto de recuperação ambiental, a maior parte da comunidade de Te'ýikue se envolveu. A visão de mundo tradicional dos jara, das espécies sagradas, da utilização das espécies, das rezas foi cultivada. Para o professor, "essa ligação com a natureza é muito forte ainda. Eu tava conversando com um colega que dizia: parece que a cultura tá num leito de hospital. O modelo de vida do não-índio tá vindo com muita força e a gente não consegue segurar isso. E a gente precisa selecionar o conhecimento ocidental".

Foi recebida uma herança de muitos processos de destruição e de modelos de utilização dos recursos naturais que são muito diferentes dos que eles viviam. Era um mundo com melhores condições ambientais. Creio que muitas questões tradicionais têm dificuldade de lidar com as condições que são colocadas hoje. Por isso, é necessário visualizar os caminhos para lidar com a situação atual, porque, por exemplo, no passado 
mais remoto não existia a braquiária. É necessário construir um conhecimento pra lidar com ela. A Unidade já tem uma teoria e uma prática.

Para o professor a sobrevivência do indígena não deve estar no trabalho assalariado, nas usinas e nas fazendas. E, sim no cultivo da terra, com a melhoria da produção alimentar. Muitos não conseguem "enxergar que ele pode produzir aqui, na própria terra. Outra coisa, é o mau planejamento dos governos. Eles acham que o que vai funcionar no assentamento, vai funcionar na aldeia". Para o professor, o que atrapalha muito são as políticas públicas, pois:

A pessoa aposentada fica dependente daquilo. Aí deixa de cultivar, abandona muito coisa da cultura. São muitas coisas que a gente sente que atrapalha mesmo. O mais velho enxerga a simplicidade de viver. Já os mais novos não quer saber. A resistência tá com a geração mais nova de não querer aceitar. Querer viver o modelo de vida não-indígena. Acha que é melhor. Avaliando bem, muita coisa não é boa, como a alimentação mesmo.

Ele vê gente com trinta, quarenta anos sofrendo de pressão alta, de diabetes e de muitas doenças: "a gente tenta refletir isso com as crianças, quando eles vêm. Eles têm que saber selecionar. Viver bem assim na comunidade. Que a gente acredita que a melhoria tá na produção alimentar. Que tem que partir daí. Não é pela cesta básica. Aqui tem família que depende totalmente da cesta básica". E por outro lado, Há muitos casos de obesidade na reserva, pois, "a alimentação é totalmente contrária. Tem poucas famílias que produzem pra consumo. A maioria trabalha na usina, quase mil homens e, o pessoal que trabalha nas obras da rodovia". Segundo o professor, eles discutem: "sobre o modelo de vida caro, que muitos querem adotar. O não-índio paga pra emagrecer, vai na academia, tudo caro. $\mathrm{E}$ o índio não, tem a represa faz a natação; tem a mata, faz uma caminhada".

Prosseguindo na caminhada, chegamos em uma represa pequena no começo da nascente, onde há lambari. É como um córrego encanado que eles chamam de ladrão de água. Ao todo foram feitas seis represas pelo Projeto Kaiowá-Guarani. Elas deveriam servir para criação de peixe também.

Vimos um lado da mata que pegou fogo em 2013 e também na semana anterior a minha visita. Os professores da unidade se reuniram com os vizinhos pra combater o fogo: "no começo a gente fazia aceiro em volta com o trator, mas depois paramos e o fogo vem destruindo tudo".

Na matinha da unidade tem macaco e jacutinga (um pássaro grande), pois, quando a mata se recupera os animais voltam. E o professor seguiu com entusiasmo mostrando as espécies da mata e dos cultivos: buriti, erva-mate, chiru, maracujá, cará, café... mostrou aveia, que também é adubo verde e tirando a semente é só incorporar ao solo. A plantação de urucum fica nomeio da braquiária e com o tempo ela vai sumindo. A unidade possui todo um conhecimento de controle natural da braquiária. 


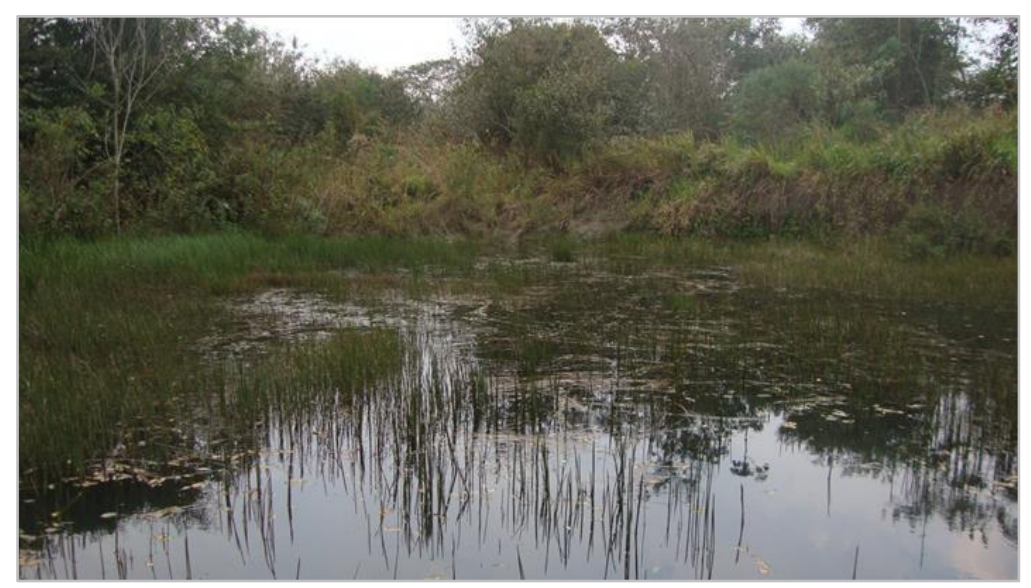

Fotografia 13 - Represa na Unidade. Fonte: Autoria própria.

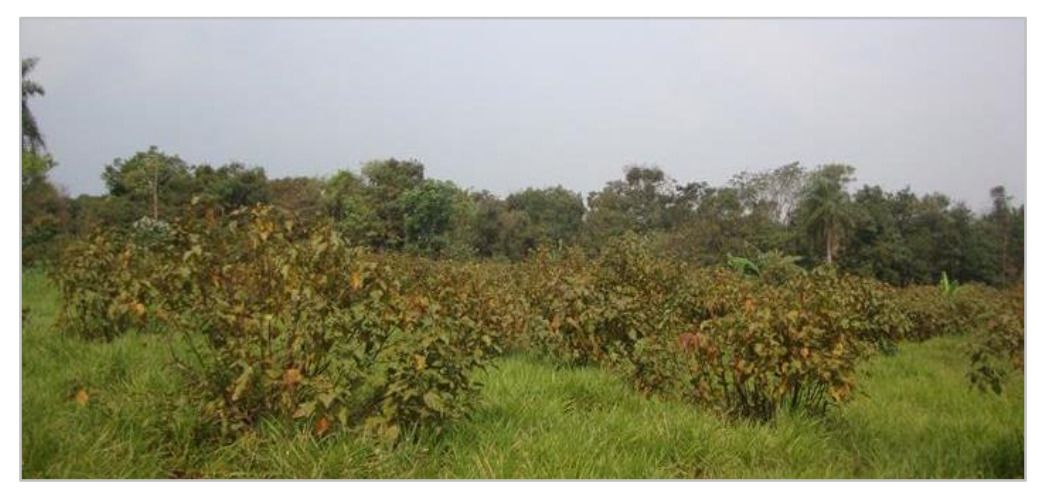

Fotografia 14 - Plantação de urucum no meio da braquiária. Fonte: Autoria própria.

O professor da Unidade acha que o projeto de recuperação ambiental avançou mais na região central e no Mbopiy, na área onde mora um dos rezadores, pois, esse rezador: "tem um contato muito forte com a escola em relação à preservação ambiental. Ele vem, aprende com nós, a gente aprende com ele também. E ele leva isso pra família dele também. Então, fica bem mais fácil de trabalhar alí". O rezador de Mbopiy é um líder espiritual para Te'ýkue. Segundo o professor: "o pessoal procura muito ele para benzer, fazer remédio caseiro. Ele é uma pessoa super aberta pra dialogar".

Em Te'ýkue há o predomínio de uma família ou parentela em cada região. O professor revelou que: "descendo o Mboipaso são famílias de diferente parentela e acabam não se entendendo. E não tem o líder, cada uma é separada". Há uma dificuldade de lidar com moradores novos que não acompanharam o processo de construção da escola e da gestão ambiental após 1997. Na região de Saverá onde existem remanescentes de mata atlântica há uma maior pressão ambiental para utilizar a madeira das árvores para construir casa, fazer cerca, chiqueiro e utilizar lenha.

O projeto do Plano de Gestão Ambiental em Te'ýkue foi encerrado em 2010, cujos resultados foram avaliados como positivos perante à comunidade, como: a construção de 
uma represa, com aproximadamente 12 hectares de lâmina d'água, sendo utilizadas para pesca e recreação; a produção e o plantio de mudas nativas; recuperação de nascentes e áreas degradadas e consolidação da temática ambiental" (UCDB, 2009, p. 1).

O legado do envolvimento da escola, da comunidade e dos parceiros é algo bastante significativo e sentido positivamente por todos com quem dialoguei nesta pesquisa. Porém, os desafios também são bem expressivos. Preservar o legado dos projetos que foram construídos em nível comunitário e levados adiante pelas famílias e a ampliação dos projetos escolares e de conservação ambiental são questões relevantes nesta conjuntura.

Do ponto de vista ambiental, o adensamento demográfico em franco crescimento com mais pressão sobre os fragmentos de mata; as constantes queimadas, em que pesem os esforços para combatê-las; o não-envolvimento dos novos moradores, por vários fatores, nas medidas de conservação; os riscos do distanciamento das novas gerações da cultura e das coisas da terra, dentre outros, desafiam professores, famílias e comunidade.

Há um saudosismo da época em que a equipe interdisciplinar do Projeto Kaiowá Guarani estava presente na vida da reserva. É visível o legado do projeto e de como várias parcelas da comunidade incorporaram os seus benefícios, que vão da educação a transformação dos seus quintais. Mas percebe-se um vácuo entre a época das atividades mais intensas do projeto com o agora, no sentido de levar adiante as conquistas. Pairam dúvidas. Preocupações para não perder o "encantamento" do passado recente. Várias falas se manifestaram no sentido de: "agora tá parado porque não tem mais assistência".

A professora indígena disse que "depois de um tempo, a UCDB se afastou e nós começamos a ter muita dificuldade agora". O professor da unidade tem a mesma percepção: "a UCDB é que se afastou da gente. A gente sente essa falta deles". O servidor 2 do viveiro também reforçou o pensamento: "faz tempo que o pessoal da UCDB não vem mais pra cá. Vinha muito, mas faz tempo que não vem". O servidor 3 afirmou:

\begin{abstract}
a gente tenta fazer reflorestamento, mas tá difícil, muita queimada. Naquela época tinha trator, combustível pra fazer aceiro. Agora acabou. Não tem mais estrutura adequada pra trabalhar. Semente tá meio parado. Nós sempre planta na beira dos açudes, na represa. Por três vezes, nós plantemos na nascente alí em baixo, mas o fogo vai lá.
\end{abstract}

Ele segue pontuando que na época do projeto tinha técnico agrícola, mas faz uns três anos que não tem mais. Mudou muito depois que a UCDB saiu de lá: "porque não tem mais a pessoa que faz a frente. $E$ a gente mesmo não tem como fazer a frente. Tem que esperar pelos outros pra decidir".

A professora não-indígena fala com pesar que: "hoje tem muito sentimento, o viveiro tá daquele jeito, abandonado. Não pode ficar assim. Temos que retomar aquilo alí." Não há recursos para produzir mudas e continuar a recuperação ambiental porque é caro: "não é só levar a muda. Tem que ter toda uma assistência pra aquela planta desenvolver". E sugeriu: 
"mas pelo menos que a gente produzisse muda, as frutíferas para os quintais. E as nativas pra comercializar e com esse dinheiro a gente conseguir verba pra continuar o trabalho aqui dentro".

Ela relembrou que houve "épocas lindas". Só que com o passar do tempo, o pessoal da Universidade foi diminuindo a atuação porque o dinheiro também acabou: "aí a gente não deu conta, como comunidade manter". Muitos não foram fazendo a manutenção das represas e foi perdendo a água: "quase todas as represas estão estouradas. A comunidade não tava amadurecida pra levar pra frente". E concluiu dizendo que: "a UCDB se afastou e depois da morte de Brand, aí que acabou tudo. Eu chamei alguns deles da UCDB que restaram, mas tá difícil. E não tem projeto, recurso que ajude a manter. Com a formação da UFGD não tamo conseguindo".

Em síntese, os períodos mais marcantes da atuação da UCDB foram: em 1996, quando foi feito o Diagnóstico Sócio-Ambiental; em 1997, o início da atuação; em 2008, término do projeto. Segue-se o dilema da construção e das garantias da autonomia de projetos pela comunidade.

\subsection{GUARDIÕES DA NATUREZA E MESTRES TRADICIONAIS}

Uma das regiões que mais circulei foi a região da missão, principalmente, por ser o lugar onde o tradutor que me acompanhou e uma das professoras moravam. É uma área próxima a uma das divisas da reserva, ou seja, está cercada de fazendas. Prevalece nesta região espécies típicas do cerrado. Lá conheci uma família de uma idosa com mais de oitenta anos, casada com um dos rezadores, que na ocasião não se encontrava, pois, estava trabalhando na roça da família que fica em outra região. Chegando lá estavam também a sua filha e alguns netos pequenininhos. Conversamos com a ajuda do tradutor que já conhecia a família e saímos para dar uma volta nos arredores das casas da idosa e dos seus filhos e netos. As casas eram de sapé, mas devido à dificuldade de encontrá-lo, as casas foram reformadas e hoje são de alvenaria. Essa região é abastecida com água encanada.

A idosa relatou que a família mora na área há bastante tempo, sendo seus filhos nascidos por lá também. No passado recente, houve vários casos de queimadas, mas hoje o fogo está mais controlado. Ela não corta árvores e, sim pega os galhos secos que caem e já estão no chão para fazer lenha. Os netos, que estudam na escola, trouxeram várias mudas de árvores, principalmente, frutíferas, para plantar ao redor das casas. Ela afirmou: "as crianças que estudam trouxeram plantas do viveiro, como poncãn, erva, pitanga". A neta falou que iria trazer outras árvores para plantar. 


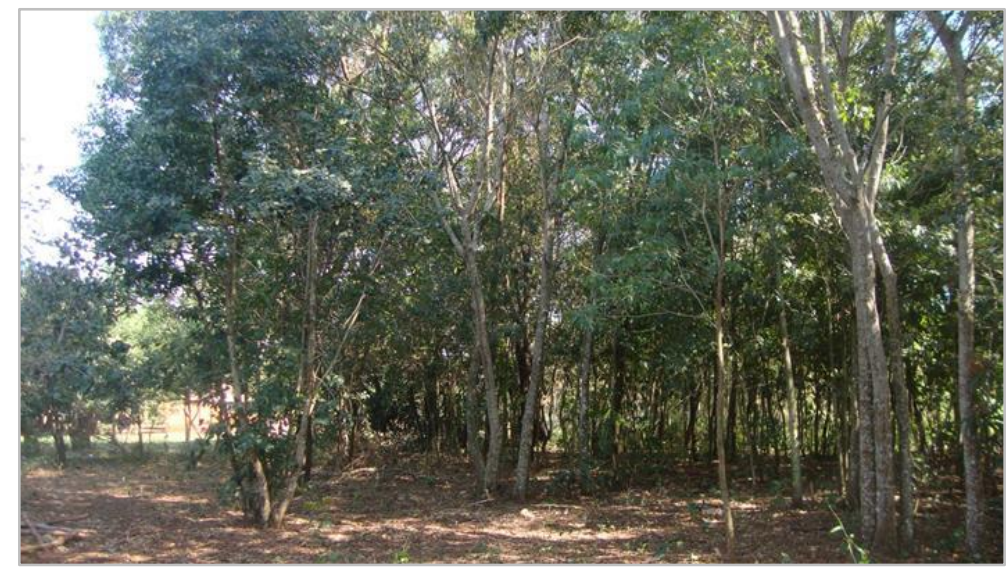

Fotografia 15 - Mata na Região da Missão.

Fonte: Autoria própria.

Há uma parte da mata da idosa em que há vários pés de guavira. Quando tem fruto, as aves vêm. Disse que com a mata muitos bichinhos voltaram, como: "tucano, lorito, papagaio, periquito, tatu, cotia, teju".

No entorno das casas há uma matinha com árvores mais velhas, provavelmente nativas e outras, com árvores jovens provenientes do replantio das atividades com o envolvimento das crianças. Toda a área possui sombra. A idosa mostrou com orgulho as árvores e plantas, identificando os seus nomes e para que servem.

Ao chegar à divisa, a idosa apontou para marcos antigos de madeira fincados na terra, que são os limites demarcatórios da reserva. Há uma estrada de terra e logo em seguida uma fazenda, como demonstra a fotografia abaixo. O trânsito de carro incomoda a ela e a família, pois, já teve atropelamento de pintinho e de cachorro.

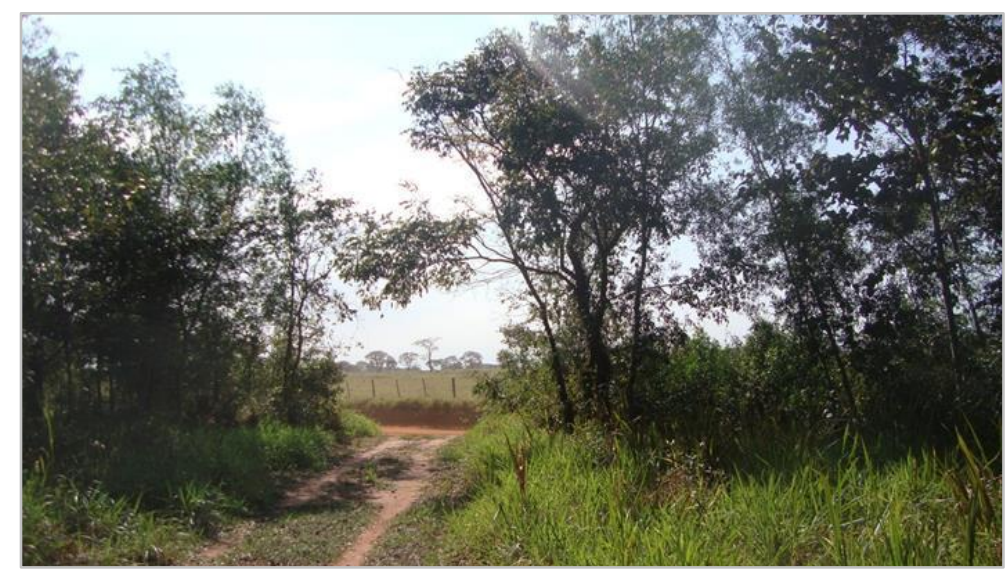

Fotografia 16 - Limite da Missão com fazenda.

Fonte: Autoria própria.

Quando a família chegou nessa região, estava cheio de mato na fazenda. Disse que antigamente ao lado era uma fazenda de gado, Fazenda Novilho. Ela acha que a braquiária veio de lá pra cá pelo vento. 
$\mathrm{Na}$ região da Missão o mato estava escasso de tanto se colocar fogo. Mas com o projeto do viveiro e das crianças levarem mudas para plantio, a mata foi renascendo, bem como com o trabalho dialogado de evitar o fogo.

Em relação aos rezadores, consegui identificar o nome de cinco deles. Um estava trabalhando na sua roça quando visitei a sua casa e dois deles estavam em outras terras indígenas por um tempo. Mantive conversa com dois, ao que me parece, os que mais colaboram com as atividades escolares e no diálogo com os professores sobre assuntos referentes à cultura.

Eliel Benites e vários professores chamam de "mestres tradicionais" os detentores dos conhecimentos kaiowá-guarani mais profundos. Para "construir a escola com a "cara" indígena era necessário retomar os conhecimentos tradicionais e, para isso, foram chamados os mestres tradicionais, para contar e partilhar os seus conhecimentos, em diversas reuniões na aldeia e na escola". (BENITES, 2014, p. 87).

O rezador de Mbokaja, com quase setenta anos, aprendeu a rezar com seu pai, avô e bisavô e também com outra família. Ele é rezador de plantas e do milho para que cresçam bem. Ele relembrou o passado ao dizer que: "a gente se reunia junto e cantava junto e rezava junto. Fazia isso quando eu era criança". Perguntado se repassa seus conhecimentos para outras pessoas, ele disse: "se alguém quiser aprender, eu ensinaria. Tudo da reza não tem no papel. Mas agora já entram de todas as coisas. Outra religião, Deus é Amor".

Ele mostrou o seu Mbaraka que usa para acalmar o vento. Ele tinha um chiru que queimou quando sua casa sofreu um incêndio. Era um chiru antigo. O que chama atenção na entrada da sua casa é um cocho de madeira onde se fazia chicha. O cocho de cedro, feito por seu pai e seu tio, tem cerca de sesenta anos, o rezador disse: "quando havia festa a gente cantava com o Mbaraka e se reunia. Agora a gente não consegue mais". Ele sabe cantar e tocar o Mbaraká, pois: "a gente acredita no sol. Cantava pro sol. Pra que o sol sempre ilumina o nosso caminho".

Seus filhos e netos moram ao seu redor, nesta região. Ele faz roça na frente de casa e também numa área abaixo da casa da sua filha. Planta mandioca e amendoim. De lá se pode avistar um dos limites de Te'ýkue na divisa com uma fazenda arrendada para o plantio de cana-de-açúcar.

Ele diz que Te'ýkue era pura mata, tinha erva, tinha tudo. Mas que hoje algumas plantas para remédio acabaram. O rezador pegava remédio na mata do fazendeiro. Mas 
hoje tem medo porque bem perto dalí uma criança foi morta por um fazendeiro quando estava pescando num córrego ${ }^{93}$.

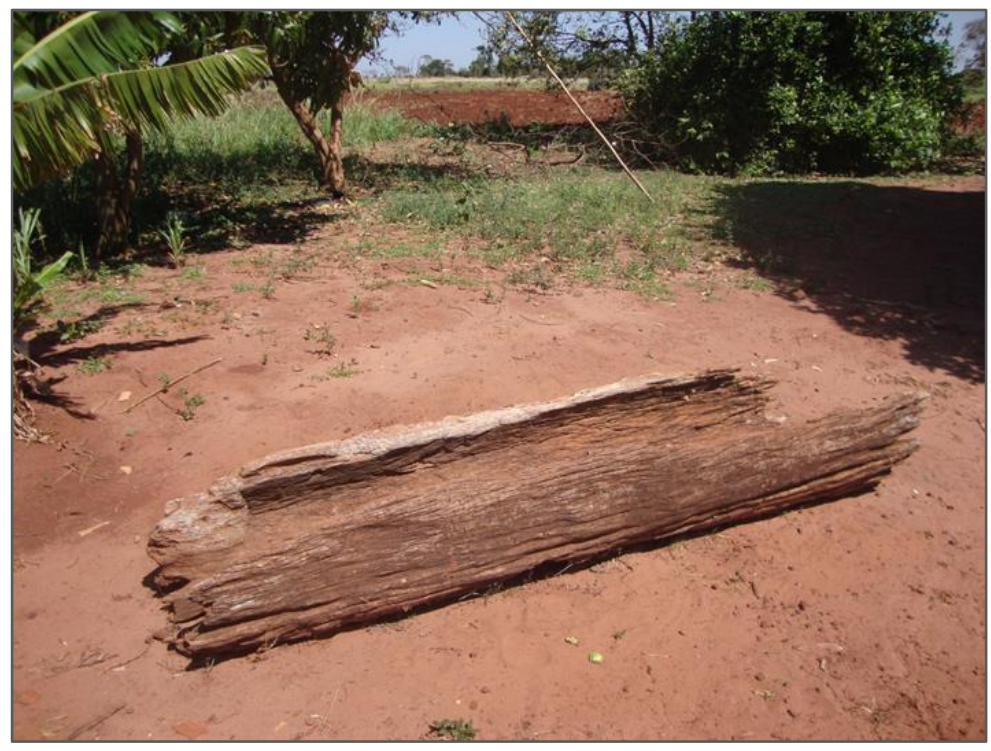

Fotografia 17 - Cocho de Cedro em Mbokaja.

Fonte: Autoria própria.

A região que mora está devastada e descampada, tendo muita braquiária e pontos de queimada. Caminhamos até sua roça onde há uma plantação de amendoim. A terra estava preparada, só faltava a chuva, mas ele iria rezar para a plantação. Ele mostrou as poucas plantas que servem para fazer remédio. Está difícil encontrar remédio no mato. Disse que: "tem no mato, mas a gente não consegue mais ir lá porque o fazendeiro proibiu entrar lá". Chegamos em um ponto no qual é possível ver a plantação de cana da Fazenda Novilho. Ele costuma pegar remédio na matinha ao fundo. A matinha faria parte do Tekohá Guasu, mas está fora da aldeia, perto de Pindoroky. Segundo ele:

\begin{abstract}
tem um córrego aí em baixo. Tatu, javali talvez tenha no mato. Antigamente, era cheio de bicho. O veneno matou tudo. A usina só trabalha por dinheiro. Desmata tudo. A gente precisa de remédio, mas se a gente vai lá, expulsa tudo. Ele não foi expulso do mato, mas teve gente que foi. Todos os animais eram nossos. Tatu e outras coisas. A gente queria matar, mas fazendeiro não deixa mais. A fazenda não deixa tirar os peixes. Por isso, o menino foi morto em Pindoroky. Se ele vai pescar, talvez o fazendeiro pode matar. É perigoso.
\end{abstract}

Sobre os animais, Ihe perguntei como fazer para eles voltarem. Ele respondeu:

\footnotetext{
${ }^{93}$ Foi o que ocorreu em 2013 numa área chamada Pindoroky, em que três indígenas estavam pescando em um córrego que passa numa fazenda e o proprietário atirou em um menino de doze anos, que veio a falecer. Este episódio levou um grupo de indígenas a ocupar a área e reivindicar a terra. Visitei a área e conversei com a liderança que disse esperar a demarcação, pois já foi feito o estudo de identificação e delimitação. A Funai solicitou uma ampliação do Grupo de Trabalho AmambaiPeguá para incluir a área de Pindoroky. Segundo a liderança, no início tinha umas trinta e seis famílias, mas agora (em agosto de 2014) restaram menos da metade. Eles têm necessidade de serviços de água, saúde e educação. O que precisam vão até Te'ýkue, mas é difícil pela falta de transporte.
} 
a gente pode chamar. Tem reza pra fazer os animais voltarem. Tem o nome do deus que manda os animais. A gente tem que chamar pra voltar, pra formar de novo o mato. Cada um deles tem um jára. Tem a reza do jára. Dois ou três rezador já faz voltar. A gente sabe a reza, mas os fazendeiros não deixa. A gente tá na divisa. Toda a terra pertence a nós. Fizeram fogo e algumas árvores acabam morrendo. O fogo que sempre não acaba.

Como a braquiária tomou conta daqui? Ele respondeu: "aí braquiária trouxe a gente mesmo quando ia trabalhar na fazenda. Trouxe no pé, a semente da braquiária. Aí espalhou. No vento. Quando a gente trabalhava na fazenda, plantava braquiária e ficou preso no pé do sapato. A gente veio e a semente se produziu aqui". Para fazer a roça tem que ter o trator porque a enxada não dá conta. O que fazer para acabar a braquiária? Ele disse: "não tem reza pra acabar".

Ele gosta de comer milho, mandioca, batata e amendoim disse que: "antigamente era mais fácil de fazer roça, de carpir. A gente quer plantar milho, mandioca. O governo não ajuda nós, não tem trator. Nós não temos condições de fazer plantação".

Os professores com quem conversei se referem ao rezador de Mbopiy como o cuidador, o guardião da mata de Mbopiy, que fica numa parte mais alta da reserva, já na divisa com uma fazenda. Relembram que a área estava muito devastada, mas com as transformações que ocorreram após 1997 ele e sua extensa família incorporaram o espírito da revitalização da terra. Hoje, apesar da insistente existência do colonião nesse pedaço de terra, uma parte considerável das árvores e plantas rebrotaram, assim como o retorno de animais silvestres. A professora não-indígena comenta sobre o rezador:

\begin{abstract}
Esse senhor ficou escutando a gente falar da questão ambiental e que se não passar fogo a mata cresce. Lá era horrível a região que ele morava. Não tinha uma sombra. Quando fomos pra lá começamos a levar as primeiras mudinhas de laranja pra ele plantar. Era um lugar que só tinha braquiária. Ele sempre foi de plantar as rocinhas dele. Mas era tão escorrido aquilo lá e sem nada que quando a chuva vinha lavava tudo. E ele começou a cuidar do fogo. Você precisa ver a parte ambiental, a coisa mais linda que tá, virou matinha mesmo. Chega é fresco lá. Renovou. Não tem mais essa parte da erosão. Ele continua plantando a rocinha dele, mas com um ambiente totalmente diferente. Continuou criando as vaquinhas dele, os cavalos, tudo que ele tem lá de bichinho. A qualidade de vida daquele povo foi lá em cima. Ele reclama do pessoal do Bocajá que vai lá pegar madeira pra fazer as casinhas. Ele falou: porque eles não recuperam lá também. Ele foi iluminado.
\end{abstract}

Além da referência como guardião da natureza é também um dos principais interlocultores culturais na reserva e participa de muitas atividades com professores e alunos. A casa de reza (óga pysy), que foi inaugurada em 2010, estava situada nessa região. É o guardador do chiru de um dos rezadores importantes, que também foi o seu mestre. Procurado por toda a reserva para batizar crianças. Mas também sofre com as dificuldades para fazer sua roça, para ter acesso à água e as constantes invasões das queimadas da redondeza e dos vizinhos que buscam a madeira das árvores que ele cuida. 
O rezador de Mbopiy, que tem quase sessenta anos, não nasceu em Te ýkue, mas mora em Mbopiy desde 1977. Para ele: “o nome Mbopiy é do buraco de morcego, que fica lá embaixo. Tem cobra de dois pés. Agora acabou, caiu o raio. Tá morando abelha lá. Lá é lugar de morcego". Sobre a origem do nome Mbopiy: "contam que antigamente tinha um buraco enorme nessa região onde viviam muitos morcegos. Certo dia caiu um raio no buraco, matou todos os morcegos e fez brotar uma nascente de água. Por isso a comunidade passou a chamar a região de 'mbopiy, córrego do morcego'" (UCDB, 2009, p. 19).

Ele chegou em Te'ýkue com catorze anos. Seu pai morreu em uma fazenda quando ele tinha onze anos. Primeiro, a mãe o levou para Reserva de Dourados, mas depois que chegou a Te'ýkue não saiu mais. E, relembrou: "o tempo aqui era tudo mato. A terra onde tá o fazendeiro era mato". Mbopiy fica na divisa da reserva. Ele disse que o lugar na reserva está pequeno, agora tem quase 7.000 pessoas: "tá tudo apertado. A gente tem bastante família, tamo precisando de terra".

Sua mãe mora em Guaimbé e tem parentes em várias terras. Todos os seus seis filhos/as moram por lá, assim como seus muitos netos/as e já vai ter bisneto. Ele afirmou: "eu tenho bastante neto e família. Quem vem aqui me procura porque tá precisando qualquer coisa pra eu fazer pra ele. Tô morando no meio da minha família. Qualquer coisa que tá errado, senta lá e eu chamo, falo que tá acontecendo. Eu sou o encarregado da família". A área é ocupada por sua família extensa e fica um pouco mais afastada das demais regiões. Alí é um dos lugares onde há nascente d’água e córrego. A família, através do rezador, assumiu a recuperação da mata.

Quem the ensinou a reza foi um rezador que era como se fosse um professor (da cultura). Este mesmo rezador ensinou a vários outros que se interessaram. Para ele, quem quer saber tem que perguntar e relembrou: "naquele tempo não tinha crente, irmão. Tinha mais rezador". Ele, por sua vez, está transmitindo seu conhecimento para um dos filhos.

Ele afirmou: "todos tem cultura não é só o rezador que tem cultura. Tem rezador, tem nosso naturalidade. Tem o chicha, tem algum guavira de campo. Tem a cana. Tem passarinho que assa e come assim mesmo. Pra nós alcançar aquilo que nós tamo deixando, tá difícil. Mas um pouco vai recordar". Durante nosso convívio, entoou alguns Porahéi (cantos) e Ñembo'e (rezas). Há uma entonação de voz diferente para cada uma.

Ele não fez o tembetá porque quando estava na idade morava na fazenda. E disse: "agora não existe mais porque a criançada não gosta. Nossa cultura não vão alcançar mais não. No Paraguai ainda tem tembetá". E, emendou: "a chicha agora é difícil porque a gente não tem mais o milho saboró".

O rezador de Mbopiy é responsável por batizar crianças. E disse: "a gente não pode batizar criança e batizar o milho. Batizar o milho é quente". Não falta gente que o busca para 
o batismo. Por isso, ele passa a maior parte do tempo lá devido a procura. Ele conhece os remédios do mato e onde mora também há alguns deles. Seu mestre foi mostrando os remédios no mato, enquanto caminhavam, durante seu processo de apredizagem. $O$ rezador revelou que: "seu mestre sabia de tudo, a mesma coisa do professor da escola. Ele aprendeu na naturalidade". Disse que há remédio para tudo e procurando se encontra. rezador se refere ao conhecimento das plantas, dos remédios e das rezas como sendo a naturalidade: "isso é nossa naturalidade mesmo".

Disse que por enquanto ainda se encontram os remédios de que precisa, mas para achar tem que andar. Na região do Mbopiy não tinha matinho, havia muito colonião. Primeiramente, ele comprou um cavalo e colocou na área do colonião. E alguns dos seus parentes compraram vacas, pois, esses animais também comem o colonião. Segundo o rezador: "a vaca comeu o colonião, acabou. O colonião não aguenta, não, um ano já é muito. A vaca passa e pisa na raiz e ia apodrecendo. Mas a braquiária não, a vaca pisa, mas sempre ela não morre".

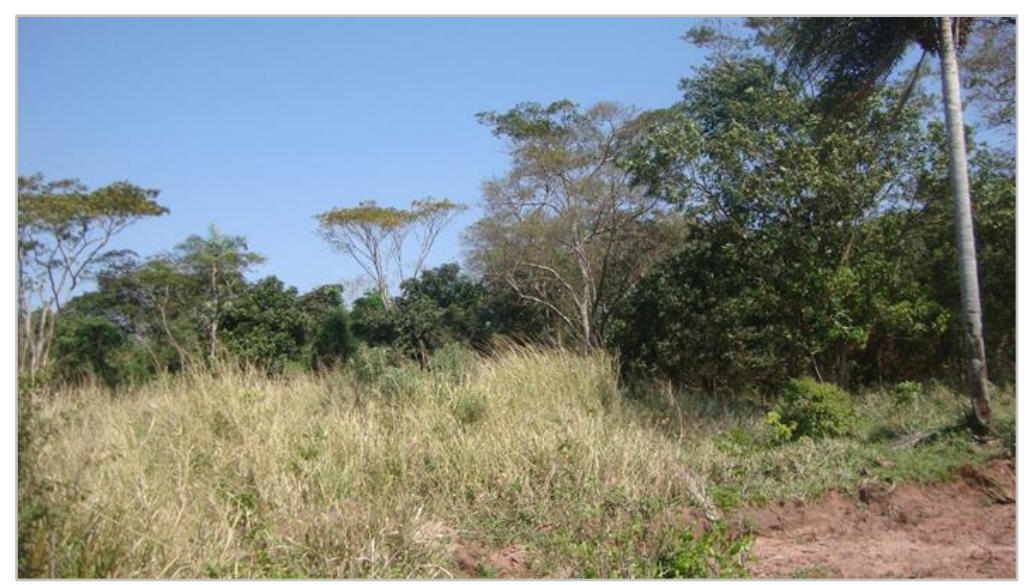

Fotografia 18 - Colonião em Mbopiy.

Fonte: Autoria própria.

Afirmou que têm uns cinco alqueires de mata em Mbopiy. Sobre o reflorestamento disse: "o projeto de Brand ajudou". Mas ele mesmo: "fez reza, batizando. A mudinha veio da própria terra mesmo". E seguiu dizendo: "tem aqui o chiru. Eu plantei tudo aí, ele já foi batizado. A gente planta aquele pedaço de chiru alí, vai virar onça aqui, ninguém não chega. Por isso que a gente não sai daqui". $\mathrm{O}$ chiru $^{94}$ do seu mestre está com ele. Depois que o mestre faleceu, seu sobrinho disse que não saberia usar e por isso seria melhor ficar com o rezador de Mbopiy: "trouxe e disse que queria que eu cuidasse dele. Se queimar produz

\footnotetext{
94 Os chirus, segundo Mura (2010, p. 11), "assumem a forma de cruzes e varas que podem variar de poucos centímetros a aproximadamente 1,2 metros de comprimento". Os chirus, "estão ligados a famílias específicas e, em seu interior, a indivíduos igualmente específicos. Assim sendo, existe um paralelismo entre a trajetória histórica das famílias (e dos xamãs que delas fazem parte) e a trajetória dos chiru a elas relacionada" (Idem, p. 4).
} 
alguma doença". Ele acredita que a presença do chiru traz harmonia. Por isso, na sua família não há briga, diferentemente das demais regiões da reserva.

Geralmente, o chiru passa de um membro da família para outro, desde que se tenha aprendido a rezar e se saiba de questões mais profundas da cultura. Quando a cadeia de parentela não consegue levar adiante este propósito, o chiru é passado para outra pessoa que conheça os ensinamentos, como foi o caso do rezador de Mbopiy que recebeu o chiru do seu mestre. $O$ chiru estava sendo guardado na casa de reza. A madeira da casa de reza era de peroba que veio da própria reserva. Mas hoje é difícil encontrar peroba ${ }^{95}$. Como a casa de reza caiu, ele agora guarda o chiru na própria casa.

Fizemos uma caminhada, na companhia de algumas de suas netas que munidas de garrafas de plástico foram para a nascente em busca de água, conforme fotografia a seguir. Percorremos uma parte da divisa de Te'ýikue que margeia uma fazenda que planta aveia. As meninas foram muito animadas à frente enquanto o avô mostrou com sabedoria as diversas árvores e plantas, bem como suas serventias medicinais, que encontramos pelo caminho.

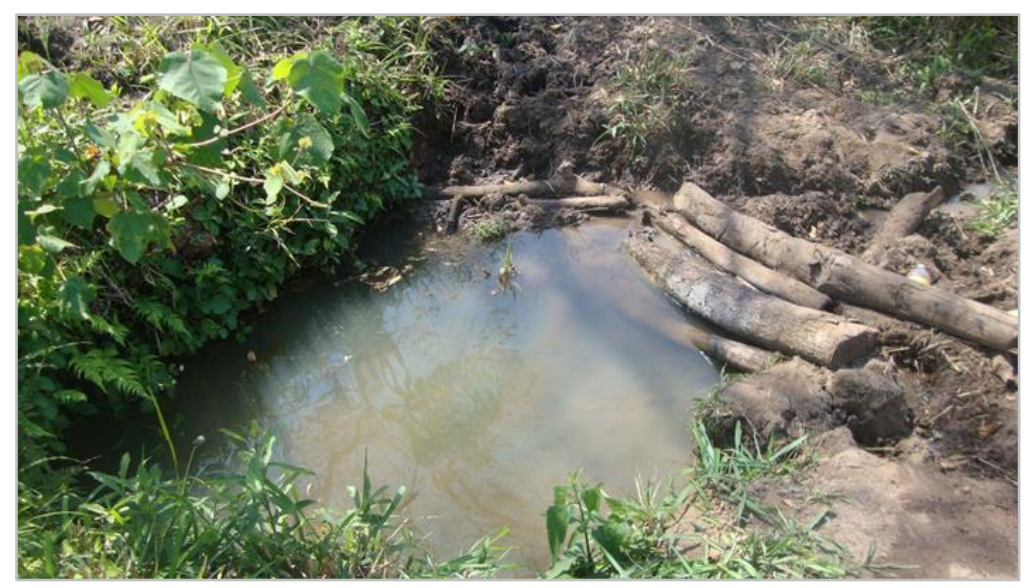

Fotografia 19 - Nascente em Mbopiy. Fonte: Autoria própria.

O rezador, que já foi ervateiro, assim como seu pai, disse que sabe fazer todo serviço. Ele tem planos de planos de seguir plantando na sua matinha e na sua roça. Inclusive, quer plantar uns pés de eucalipto para usar como lenha e parede da casa para não cortar as outras árvores. Afirmou: "a gente corta aí, vai perdendo".

Sobre a sua interação com a escola, disse que eles o procuram muito: "trabalha junto com eles e as crianças sempre vão lá para aprender". Narrou que: "um dia veio irmão. Pra começar a gente faz um Jeovasá. E ele não quer fazer. Eu disse: isso aqui é a mesma coisa da igreja. Você tá lembrando com Deus, eu também". Nenhum dos seus parentes é

\footnotetext{
${ }^{95} \mathrm{O}$ rezador falou de um chefe antigo da Funai que vendeu peroba e outras árvores: "a gente era bobo. Pode vender, nós tá precisando trator. Pegou vendeu". Deixava cortar a madeira, por volta dos anos de 1970.
} 
evangélico, mas afirmou: "o pessoal da missão vem um dia aqui pra fazer um cultinho. A gente deixa porque eles ajudam a pessoa que tá carente. Dando roupa. A gente deixa aí. Outros crente a gente não deixa".

Passamos por uma área extensa em que havia colonião muito alto, acima da altura do rezador. Mas, mesmo no meio do colonião, ele conseguiu identificar plantas para fazer remédio. Mostrou que também existem brotos de árvore no meio do colonião, porque seria o lugar original dele. Por isso, disse que é contra o fogo: "se queimar, se perde". E seguiu: "eu quero que nasça de novo isso aí. Se queimar vai terminar".

Para ele, o que acaba o colonião são as vacas que o vão macetando. Ao ser perguntado sobre o que gostaria de plantar na terra caso acabe o colonião, ele respondeu: "colocar outra qualidade de muda". A matinha do rezador é um oásis no meio do colonião. Há vários brotos de árvores e de plantas medicinais no meio do colonião e da braquiária.

Revelou que tem gente brigando com ele porque quer derrubar a mata para pegar madeira: "tem gente dizendo: vou pegar aquele veinho, amarrar no pau". No limite de Mbopiy ele colocou uma cerca para os animais não passarem: "mas sempre o pessoal vem tirando a mata". Mostra onde alguns cortaram árvores, inclusive a própria madeira da cerca. Nas suas observações, tem gente da reserva que queima o mato: "teve uma vez que o vizinho queimou o roçadinho e passou pra cá o fogo".

Ao dizer: "a gente precisa a melhoração aqui", falou da importância da reconstrução da casa de reza e da necessidade de acesso a água e do apoio para fazer roça. Nessa região não tem água da Sesai. "A gente tá tomando água há uns 700 metros daqui". Para ele é preciso "fazer o projetinho".

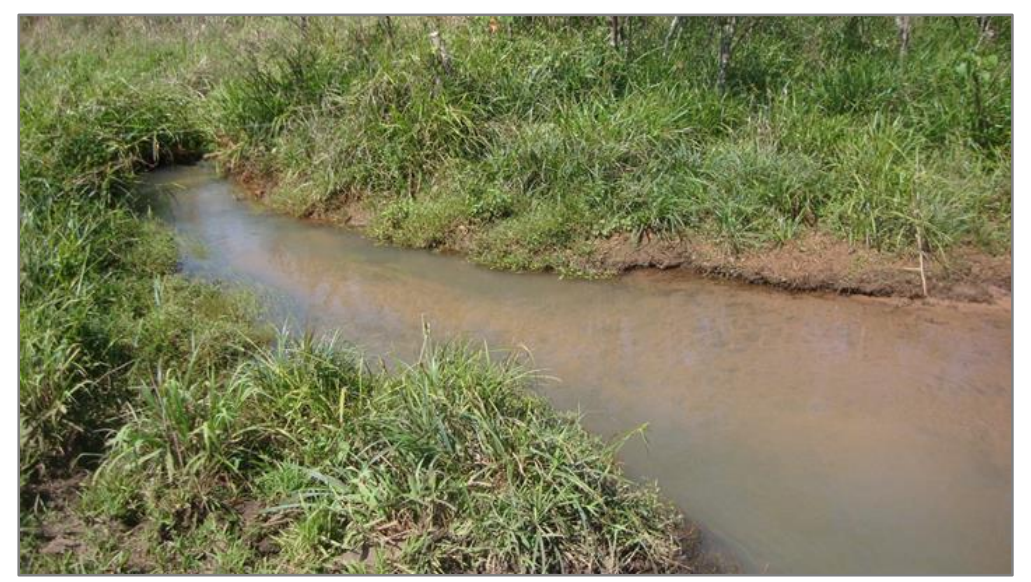

Fotografia 20 - Córrego em Mbopiy.

Fonte: Autoria própria.

Pergunto o que seria sustentabilidade. Ele respondeu: "como que a gente vai melhorar. Achar o caminho mais limpo pra ficar bem mesmo, contente, dentro da família. 
Tudo a coisa que a gente tem. Tem porco, galinha, arroz. Não vai mais precisar de dinheiro pra tratar a família. A gente não pensa isso aí".

Ele tem dois filhos e genros que trabalham na usina: "quando acabar a cana, acaba esse trabalho. A gente trabalha no natural. Dá a sustentação pra pessoa". E prosseguiu: "eu tinha bastante mandiocal. Aí acabei. Aí eu comprei $R \$ 2,50$ o quilo mandioquinha em Caarapó. Aí eu falei pra mulher, a gente sabe plantar, como é que a gente vai comprar?" Agora, toda a família tem mandiocal e milho. E concluiu: "primeiro a gente começou o projetinho com Brand, ajudar aqui, ele não volta mais. Por isso que a gente ficou parado. Não sabe mais como vai organizando. A gente pensa como vai vivendo".

O rezador guarda o mato, mas também o jeito de ser. Guarda o chiru, que foi passado das mãos de rezadores antigos e importantes. Alí que esteve e estará a casa de reza. Ele instrui o filho para continuar com sua função. Faz encontro com outros rezadores e mantém diálogos com a escola. Por isso, exerce um papel simbólico para toda a Reserva. Por isso, ele assumiu uma liderança nesses aspectos. Mas, ao mesmo tempo, ele precisa de alternativas de sobrevivência.

Durante a pesquisa de campo foi possível acompanhar um encontro dos professores com o rezador de Mbopiy, na Escola Loid, para dialogar sobre aspectos da cultura e de como transformar esse conhecimento em prática pedagógica. Sua fala foi em guarani, mas um dos professores traduziu seu discurso. Reproduzirei alguns trechos que considero mais relevantes para a análise da tese.

O rezador de Mbopiy disse que: "o aprender no sistema Guarani-Kaiowá é amplo, complexo. É bom ficar atento porque o ensinamento Guarani-Kaiowá usa muito a metáfora. Como é feito no dia-a-dia e levar pra escola. Pro aluno ser crítico na sua realidade, no seu contexto". Muitos professores reclamam que o aluno não se comporta na sala de aula e têm dificuldade de manter o domínio da turma. Para o rezador, isso ocorre porque: "muitas crianças não são batizadas na cultura. Isso gera criança rebelde na família e na escola. Por falta desse acompanhamento desde criança. O professor indígena tem que ficar atento para dialogar. Repensar a prática na sala de aula. Sentir para repensar a prática". Sobre a relação da educação tradicional indígena e a escola formal indígena:

desde criança, se aprende na prática Guarani-Kaiowá. A escola ensina a
teoria. Nem sempre se consegue fazer essa conexão. O aprendizado
Guarani-Kaiowá tem um jeito de ensinar. Professores devem pensar a fala,
o jeito, a metodologia de ensino. Ensinar e aprender Guarani-Kaiowá.
Aprender e ensinar através da natureza. Trazer a referência dos líderes
espirituais e políticos Guarani-Kaiowá para a aprendizagem Guarani-
Kaiowá. São mestres, doutores na nossa cultura. Conviver com isso,
crescer com isso. Teatralizar a cultura: viver e mostrar.

Uma apresentação de dança na escola para representar a cultura, por exemplo, é um teatro da cultura, não é mais o que se está vivendo. Por isso, é necessário trazer a reflexão 
da prática da escola e fazer a interação entre a educação tradicional na família, na comunidade e na escola.

O professor indígena assimilou a cultura do não-índio, isso pode interferir na prática, na desvalorização da cultura, da língua, da identidade, da reza e da dança. É preciso criar estratégias de garantir a sustentabilidade da cultura e da identidade e enfrentar o que vem de fora. É importante incorporar o jeito próprio de ensinar - o teko - saber respeitar o outro, saber conviver com um grupo diferente. Para o rezador: "respeitar o diferente do outro. Isso é um ensinamento Guarani-Kaiowá. De ser solidário com o outro, de ser um jeito simples, de ser um exemplo de você ensinar o outro. A gente tem que começar por a gente mesmo pra ensinar o outro".

Foi muito ressaltada a questão de se tomar cuidado com a prática, sobre o que está sendo ensinado para os alunos. Porque se os professores não tomarem cuidado com a prática pode gerar algo positivo ou negativo, principalmente, na questão da cultura e da língua. Para o rezador: "se a gente sempre valorizar o que vem de fora, por exemplo, tecnologia, isso interfere diretamente na nossa cultura. Se a gente não tomar cuidado, pode perder a nossa identidade como Guarani-Kaiowá". Sobre o ensinamento, foi colocado como exemplo a família do próprio rezador, pois, "a educação começa dentro e vem da família. Isso deve ser levado em consideração na escola, pra dar a sequência da educação na escola. O que a gente aprende, não vão tirar da gente".

Ele reforçou a importância da parceria do trabalho entre escola e rezadores, pois, "esse é o momento da escola indígena trabalhar sempre com Ñanderu. Fazer essa troca de experiência. Dessa prática dele ensinar pra nossa escola". O jeito de ensinar do GuaraniKaiowá é através de metáfora e o professor-tradutor deve interpretá-la como "se fosse uma piada no meio de uma conversa".

Para Eliel Benites (2014, p. 76) a educação escolar indígena deve retomar a cosmologia tradicional e a espiritualidade, construindo um espaço onde se possa: "iniciar nosso exercício da autonomia, buscando caminhos para reafirmar e fortalecer os valores tradicionais, em diálogo com outros saberes; é um espaço que possibilita a retomada dos valores tradicionais, porque são eles que estimulam o ser Kaiowá e Guarani”. 


\section{TERRA SUCURUI'Y}

\subsection{O RIO DE SUCURI}

O reconhecimento de Sucurui'y como terra indígena, hoje em dia regularizada, deuse a partir de um amplo processo de luta iniciado nos anos oitenta, no contexto de reivindicações pelo qual também passaram outras terras. Entre a instauração do relatório de identificação e delimitação até a regularização foi um longo período marcado por inúmeros processos judiciais.

A portaria 1.154, de 17/11/1993, com suas retificações de no. 1.184, de 23/11/1993 e no. 552, de 06/06/1994, estabeleceu a constituição de um grupo de trabalho para proceder ao estudo de identificação e delimitação da Terra Indígena Sucurui'y, localizada no município de Maracaju, em MS. Por ocasião do início deste estudo e de seu relatório, grande parte da comunidade encontrava-se em uma pequena área na periferia do distrito de Aroeira (Prudêncio Thomás), no município de Rio Brilhante. Foi o que o relator chamou de "o desterro de Aroeira" (COUTINHO JR, 1995, p. 137).

Os kaiowá de Sucurui'y habitavam tradicionalmente o território localizado às margens do córrego cachoeira, como é chamado pelos não-índios, ou sucurui'y (rio de sucuri). nome vem da grande quantidade de cobras sucuris encontradas neste corpo d'água. A topografia revela marcos simbólicos do território que são identificados através de elementos da natureza como córregos, animais e pedras. Coutinho Jr (1995, p. 137) enumera alguns destes marcos sagrados significativos que estão ligados à memória coletiva: Yakãjú Ryapykua, pequena cabeceira do córrego amarelo, conhecido também como córrego Taperinha; Guyramba Tujukue, barreiro que foi do passarinho; Tujupirã, barreiro do peixe; Pirapo, lugar onde peixe vai muito; Jaguaretekue, lugar que foi da onça; Itapesy, grande pedra lisa; Yopantikue, lagoa parada; Añáyroka, terreiro do espírito; Yvyrakuãndy, lugar do incenso; Yvytyry, morro cujo dono canta a noite para chover; Hogãtáva, mundo subterrâneo. Alguns deles estão representados no mapa feito por uma das atuais professoras da terra.

A implantação das primeiras fazendas na região, seguida anos depois, por suas titulações cartoriais, fizeram com que, paulatinamente, os indígenas fossem expulsos ${ }^{96}$, gerando muitos conflitos entre os ditos proprietários, o poder local e os indígenas. Estes sempre estiveram, apesar dos inúmeros desterros, circulando por seu território, o que constituía uma "ameaça permanente" para os titulados da terra.

\footnotetext{
96 Segundo Coutinho Jr (1995, p. 81), "A raiz do progressivo desapossamento fundiário a que se viram sujeitos os índio que ocupavam as imediações do córrego Cachoeira está inextricavelmente ligada à chegada das famílias Alves de Lima e Corrêa da Silva no planalto de Maracaju. Aí estas famílias irão adquirir terras dos herdeiros do Barão de Antonina, ou transferidas por seus representantes, no interior das quais continuavam a existir inúmeras aldeias kaiowá".
} 


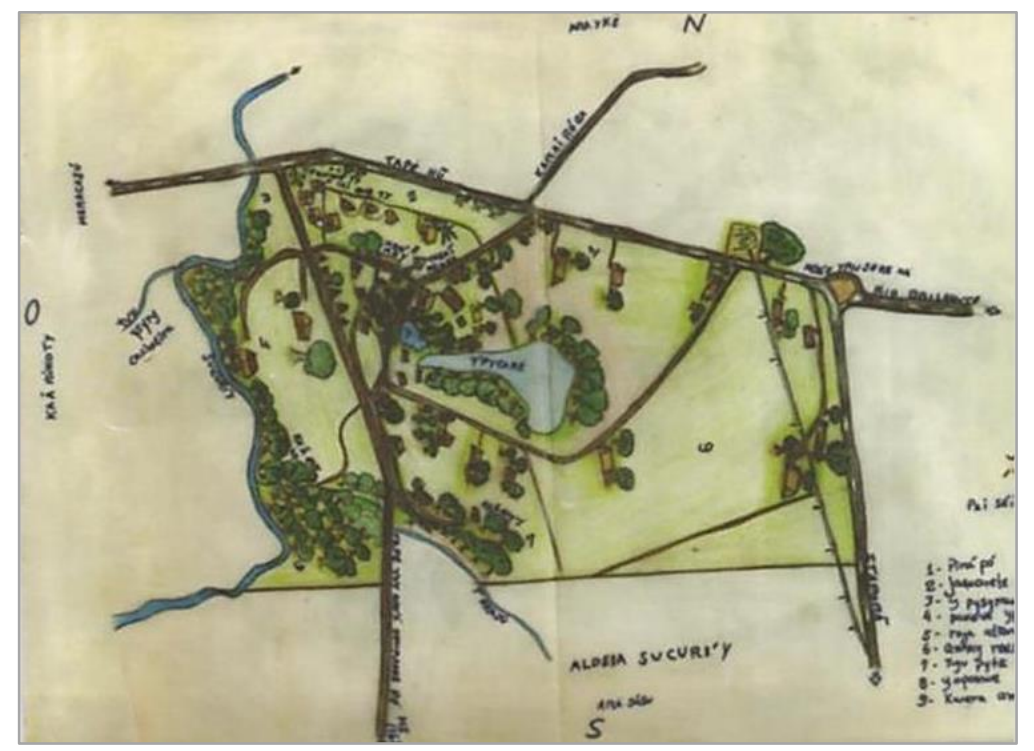

Croqui 2 - Cartografia étnica de Sucurui'y. Fonte: GUARANI HÁ KAIOWÁ, 2011, p. 77.

Em uma breve cronologia das saídas sofridas pelos kaiowá de Sucuruíy, percebe-se que as iniciativas ocorreram pelo titulado da Fazenda Alegria (cujo título de propriedade de 4.229, 762 ha, foi expedido na década de 1950), área incidente sobre a maior parte da terra indígena.

Em 1947, através de um decreto-lei de no. 86 foi criado um Posto Agropecuário do Ministério de Agricultura, desapropriando duzentos hectares da Fazenda Sete Voltas (pertencente ao mesmo proprietário da Fazenda Alegria). Isto resultou em uma demorada disputa judicial, por mais de vinte anos, entre o fazendeiro e o Ministério, na terra pertencente aos índios. O registro do título em favor da União só veio a ocorrer no início da década de 1980, após um intenso debate nos tribunais sobre a anulação da desapropriação e reintegrações de posse. Como a relação entre os servidores do posto e os indígenas foi amena, várias famílias passaram a ocupar a mata situada nos fundos do posto, junto ao córrego Cachoeira.

Coutinho Jr (1995, p.99) narra que o fazendeiro "desmatou grande parte da área recoberta em 1983 por vegetação nativa entre as instalações do Posto e o córrego Cachoeira, para o plantio de soja ou arroz". A partir daí, ocorreu a expulsão da comunidade que habitava a área do posto, pois, o fazendeiro soltou o gado nas roças dos kaiowá, que foram "obrigados a morar na beira da estrada Maracaju-Rio Brilhante em barracas de lona plástica”, na BR 267.

No início de 1985, os indígenas foram retirados das margens da rodovia pela polícia rodoviária federal e pelo DNER e a partir daí: "foram alojados em um terreno cedido pela Prefeitura de Maracaju na Vila Adrian, periferia pobre da cidade" (COUTINHO JR, 1995, p.100). Um ano depois, a prefeitura os desalojou e eles decidiram retornar a área do posto 
do Ministério. Isto reiniciou mais uma série de reintegrações de posse pelo fazendeiro. Três famílias "aceitaram dinheiro do fazendeiro e deixaram o local", enquanto que as demais "foram obrigadas a embarcar em dois caminhões 'caçamba' cedidos pela Prefeitura de Maracaju e transportados para a área indígena de Dourados" (Idem).

Em 1987, estas famílias por "pressões de espaço e desavenças com outras famílias locais", dirigiram-se a Reserva de Rancho Jacaré, onde também passaram pouco tempo e voltaram para a periferia de Rio Brilhante, em um espaço de um hectare para quarenta e duas pessoas, chamado Vila Aroeira, distante cerca de $100 \mathrm{~km}$ de Sucurui'y e por onde permaneceram por quase uma década. Quanto às demais famílias, estas se espalharam por fazendas ou outras terras indígenas (COUTINHO JR, 1995, p.101-2, 138).

O relatório de identificação e delimitação, de 06/03/1995, concluiu que Sucurui'y é uma área tradicionalmente ocupada pelo kaiowá, perfazendo quinhentos hectares e possuindo na ocasião:

uma pequena faixa de mata que margeia o córrego Cachoeira e seu pequeno afluente, o córrego Taperinha. Ali os kaiowá desenvolviam a caça, espalhando seus mundéus em locais visitados por pequenos animais, a pesca e a coleta. Aliás, a maior parte da zona compreendida entre o Cachoeira e o açude chamado pelos índios de 'barreio do Passarinho' foi desmatada em período não muito distante pelo fazendeiro, que ali passou a cultivar milho, arroz e soja (Idem, p.101-2, 150).

Em 17/05/1996, foi publicada no Diário Oficial a Portaria 300, declarando de posse permanente dos índios a Terra Indígena de Sucurui'y, com superfície aproximada de 500 ha. E pelo Decreto de 14/04/1998, foi feita a homologação da demarcação administrativa. Quando se pensa que a epopeia havia chegado ao fim, os kaiowá de Sucuruíy tiveram que esperar quase uma década, pois, a posse definitiva só veio a ocorrer em 2007, após inúmeras ações judiciais travadas pelos "ex-proprietários" da terra contestando os atos administrativos que deram origem a homologação.

Após a demarcação da terra, foi feito um acordo homologado pelo juiz da $1^{\text {a }}$ Vara Federal em Campo Grande, em 08/08/1997, no qual os indígenas puderam permanecer em 64,9 ha da terra homologada (de 535 ha) até o final da decisão judicial ${ }^{97}$. O MPF propôs Ação Civil Pública (no. 1997-00864-9) pleiteando a desocupação ou desintrusão da área pelos fazendeiros e pelo município de Maracaju visando a assegurar a reocupação da área indígena.

Entre 1997 e 2007, os processos de destruição da mata e da terra avançaram, pois, a mesma continuou sendo intensamente utilizada, inclusive com vários contratos de arrendamento, principalmente, à Fundação MS para Pesquisa e Difusão de Tecnologias

\footnotetext{
97 Enquanto pairam na justiça as ações que questionam atos administrativos da homologação de terras indígenas, o MPF tem utilizado a estratégia de propor acordos visando a assegurar uma parcela da terra pelos indígenas até a decisão final. É o que está ocorrendo em Jatayvary, como se verá no próximo capítulo.
} 
Agropecuárias. Segundo informação da Fundação, a área utilizada tinha aspectos de degradação, com a presença de compactação de solo, erosão, voçorocas, trilheiros de gado, cupins, formigueiros pedra, altos índices de acidez, baixos níveis de fertilidade e baixa capacidade produtiva.

Há uma dificuldade no reconhecimento de direitos, por parte principalmente do estado e do município, às comunidades indígenas que se encontram nas chamadas "áreas de litígio" para fornecerem serviços como energia elétrica, água, escola e outros benefícios. Em uma "Carta aberta à população", as lideranças de Sucurui'y denunciaram que aproximadamente cento e cinquenta famílias continuavam dispersas na beira de estradas ou em outras terras indígenas, enquanto que os indígenas que ficaram nos 64,9 ha da terra homologada estavam "rodeados de lavouras e cercados de arame farpado por todos os lados". E, alertaram: "Vivemos como numa prisão dentro de nossa terra". É revelador o processo de espoliação que se seguiu conforme a narração da carta de 14/06/2005:

Quando lutamos por alguma melhoria dentro de nossa terra, como escola
indígena, posto de saúde e água encanada, sempre ouvimos a mesma
resposta: esta área está em litígio. Então nos perguntamos, se os 535
hectares, totalmente regularizados como nossos, estão em litígio, como os
fazendeiros continuam plantando normalmente em mais de $90 \%$ de nossa
terra e nós continuamos na miséria? E mais grave ainda é que os
fazendeiros cercam nossa aldeia, usam grandes quantidades de veneno
que além de ir matando a terra, contaminando os rios, prejudicam muito a
nossa saúde. Cada vez que passam veneno ele vem até nossa casa e
ficamos com uma espécie de gripe, diarreia, vômitos, pneumonia e febre.
Estão nos envenenando. Nossa saúde vai se acabando e nossa terra
morrendo. Esta é uma situação muito triste que não pode continuar (grifos
deles).

Da constituição das primeiras fazendas na região em meados do século XIX até a retomada da reconhecida terra indígena em Sucuruíy nos anos 2000 com a declaração definitiva de nulidade e extinção dos títulos de propriedade dos fazendeiros, sem "direito a recurso", com as ações "transitadas em julgado" foi uma longa jornada. Principalmente, a partir da década de 1950, os processos de destruição e de expulsão do povo que pertence à terra foram se acumulando.

São muitos os desafios que se apresentam como poderemos analisar ao longo deste capítulo. Mas as margens do rio de sucuri, local de resistência por anos a fio das famílias, mostram que há muita vida nas águas que correm. As inúmeras idas e vindas a este local demonstraram a importância da mata para a sobrevivência nos períodos mais difíceis pelo reconhecimento da terra. Das gerações mais velhas, que acompanharam o processo de retomada e reverenciam a mata com as rezas, aos seus descendentes mais jovens, que a utilizam como local de lazer e aprendizado, sua conservação é importantíssima para suas vidas. 
Em Sucurui'y foi feito um trabalho de campo prévio, em dezembro de 2013. Na ocasião, estive com o professor, com a rezadora e, principalmente, com a liderança à época. No campo mais aprofundado, que foi realizado em agosto de 2014 foi possível conversar com todos os professores indígenas da escola, vivenciando um pouco a rotina escolar; fazer uma visita à lagoa com uma das professoras e sua turma; conversar com os rezadores, com a liderança e realizar uma caminhada na mata. O professor tem um tríplice papel: na escola onde trabalha; como vice da atual liderança (ele mesmo já foi liderança em outra ocasião) e como filho de um dos rezadores de uma família que é originária desta terra, estando à frente do processo de retomada da mesma. Destaco a gentileza e disponibilidade que todos tiveram comigo durante nosso período de convivência.

\subsection{TEMPO DE REALIDADES}

4.2.1 A terra: tem sucuri, tem onça, mas também braquiária

A MS-162 ou Rodovia João da Matta Côrrea, estrada de terra com cascalho, divide a terra indígena. Em um dos lados da MS vê-se mais mata com árvores de grande porte e umas poucas casas. Já do outro lado, há mais casinhas espalhadas, todas do mesmo modelo, de alvenaria, sem pintura e com telha. É mais comum encontrar casas de alvenaria em terras regularizadas. Muitas foram construídas através de políticas específicas. "Minha Casinha", em tradução do guarani "Che Rogami”, foi o nome do projeto do governo estadual que construiu casas nas aldeias, inclusive em Sucurui'y. São dois quartos, uma sala, uma cozinha e um banheiro, mas elas são fracas, quando bate um vento forte destelha o teto (vi algumas casas nessa situação).

Atualmente, é difícil encontrar madeira e sapé para fazer e manter as casas, por isso, algumas são feitas de lona. Muitos indígenas com quem conversei acham que se tivesse árvore e sapé seria melhor para construírem suas casas. Como as casas de alvenaria do governo são pequenas e as famílias são grandes, geralmente, se faz uma extensão do espaço construído, às vezes de madeira nas paredes e sapé no teto, como pode ser vista na fotografia abaixo, casa pertencente à rezadora.

Após os limites da terra indígena, percorri a MS-162 para sentir a paisagem e conhecer melhor o entorno, onde pude verificar que ao longo da estrada o plantio de soja e de milho se revessavam nas vastas extensões das fazendas, cujos nomes com placas indicativas são: Bálsamo; Cachoeira; Invernadina; Guariroba; Millenium; Nova Floresta; Nova Floresta II; Floresta; Bacurí; Volta Rica; Parte Voltas II e Arizona. São vistas ilhotas de vegetação nativa no meio das monoculturas. Em algumas delas, há também plantio de cana-de-açúcar. É frequente a presença de placas cor amarela com a mensagem: "Atenção 
Tráfego de Veículos Longos nos Próximos X Km". Há uma ponte na MS que estava quebrada, não aguentando muito peso. Além disso, a circulação de caminhões, que aumenta na época das colheitas, levanta muita poeira. O município de Maracaju é um dos grandes produtores de soja, sendo esta uma das suas principais economias.

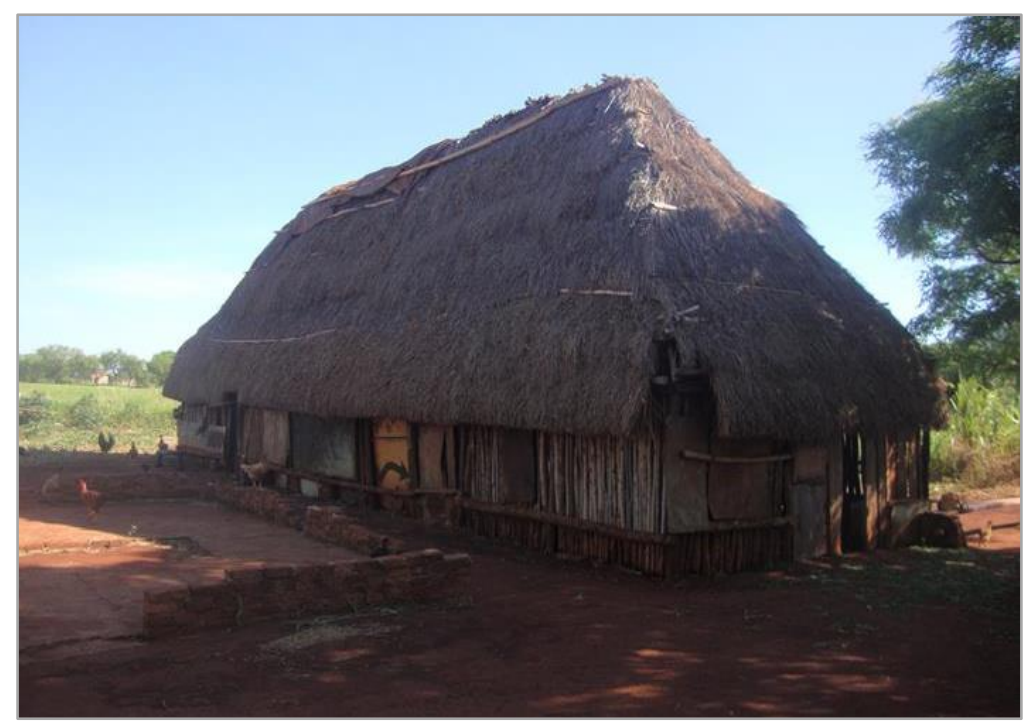

Fotografia 21 - Casa de sapé em Sucurui'y. Fonte: Autoria própria.

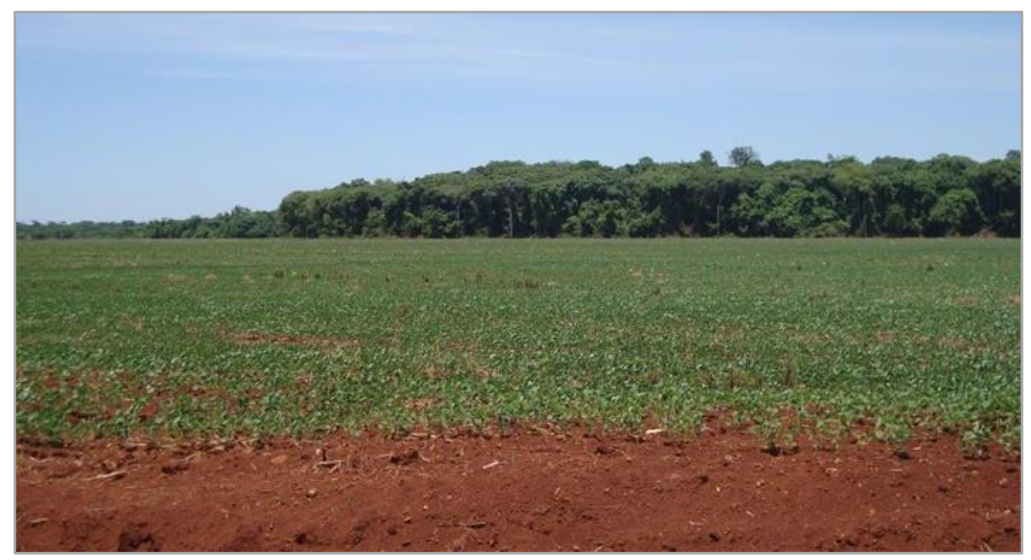

Fotografia 22 - Monocultura no entorno de Sucurui'y Fonte: Autoria própria.

Segundo a liderança, passando da cidade de Maracaju já começa o plantio de cana. Há muito tráfego de caminhões que passam na estrada que corta a terra indígena, principalmente, quando é a época da colheita de cana. Eles temem o trânsito de veículos por causa das crianças, segundo a liderança: "sabe como é, quando desce do ônibus quer sair correndo. Ainda não teve atropelamento, mas tem vez que a gente fica com medo. Tem um risco. Falamos com o DNIT e eles vão pôr quebra-mola. Em três lugares. Porque alí não temos a sinalização de placa". 
No centrinho de Sucuruíy estão localizadas a escola, o posto de saúde e a caixa d'água. É a área na qual as famílias entraram quando houve a demarcação. A caixa d'água foi construída em 2004 e a escola passou a atender alunos das séries iniciais do ensino fundamental, que fica ao lado do postinho de saúde, hoje gerenciado pela SESAI. Sobre o Posto de Saúde, inaugurado em 2006, a liderança esclarece que, funciona da seguinte forma: as terças e sextas ocorrem as consultas com um médico que vem de Dourados. Quando precisa exame é necessário fazer na cidade porque no posto não tem equipamento. Há uma dentista vai duas vezes por semana. E, também uma agente de saúde, duas enfermeiras e um motorista.

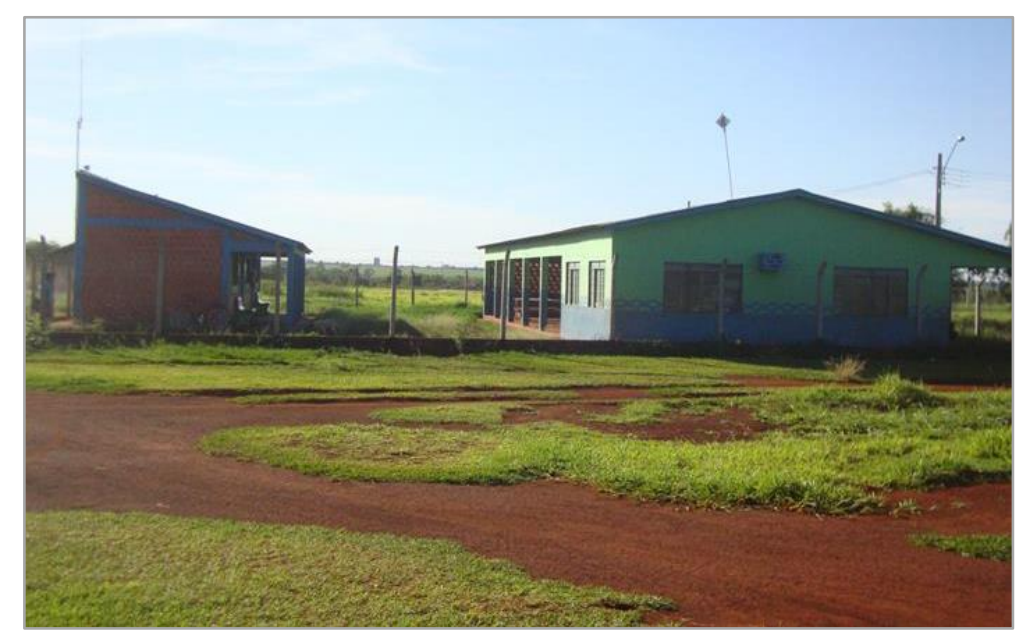

Fotografia 23 - Centrinho de Sucuruíy. Fonte: Autoria própria.

Para a liderança e o professor quando eles estão doentes procuram o médico; se o remédio não faz efeito, eles procuram o remédio caseiro com rezador. O próprio pai do professor, que é rezador falou: "tem que fazer essas duas coisa. Hoje em dia é assim, tem que experimentar o do branco, se não resolver, depois o nosso". Mas segundo a liderança, em Sucurui'y não tem muito problema de saúde: "é mais com criança e recém-nascido. $E$ também quando o clima está quente e por conta das queimadas".

Por ocasião do campo prévio, verifiquei que algumas famílias que moram perto da mata, ou seja, do outro lado da MS-162, não estavam sendo atendidas com serviço de água encanada. A comunidade é atendida com serviços de eletricidade, inclusive várias linhas de transmissão estão situadas na terra indígena. De acordo com informações da agente de saúde são duzentas e setenta e quatro pessoas e setenta e sete famílias em Sucuruíy.

A ex-liderança me explicou como foi feita a divisão interna da terra pelas famílias. Aquelas que lutaram mais pela terra ficaram com uma maior quantidade de hectares. Essa terra vai sendo passada dos pais para os filhos. Não há cerca entre a casa e a roça das famílias, todos podem circular, mas não podem pegar o que é do outro. Na comunidade não 
há excedente suficiente de lavoura para vender para fora, mas, às vezes, as famílias trocam o alimento entre si. Todos com quem conversei reclamam da falta de assistência técnica ou de projeto de agricultura e de desenvolvimento.

No campo aprofundado, a liderança, que tinha trinta e cinco anos, estava há cinco meses no posto. Ele é bem integrado com os professores da escola e com seu vice, que é professor. Sua presença é constante neste espaço, além disso, sua esposa também trabalha na escola. A liderança anterior (com quem conversei no campo prévio) é cunhado deste mesmo professor, que opina sobre o mesmo dizendo que: "ele é gente boa, mas não tinha muito diálogo, encaminhamento pra comunidade". Ele ficou três anos no cargo. Antes disso, o professor foi liderança por cinco anos e a liderança anterior (seu cunhado) era seu vice, ou seja, ele vem participando da vida política de Sucurui'y em vários momentos.

Sobre as regras políticas de escolha das lideranças, o professor esclareceu que o anterior não foi votado e sim, indicado: "aí depois a gente botou a comunidade pra votar". $\mathrm{E}$, fizeram duas chapas. A primeira, com a liderança anterior, que recebeu dezesseis votos e a segunda com a liderança atual, que venceu com oitenta e um votos. Cerca de vinte pessoas não foram votar. O curioso detalhe é que a partir dos doze anos poderia se exercer o direito de voto. O professor falou: "ganhou a 2 que é a nossa. Depois que a gente ganhou, falou pra comunidade: vocês tem que colaborar. Cacique é como juiz. Cacique prende e defende e o julga e vai indo. O cacique diz que o que fizerem tem que assumir o que faz". A atual liderança reforçou: "tem que agir com a lei. Qualquer coisa a gente procura a Funai, a Prefeitura, a polícia".

Para o professor, "com a comunidade tem que ter garganta, tem que falar, que perguntar: que que você pensa, que você sente?" Ele ficou responsável pela parte do jovem e tem projetos para ensinar a tocar violão e o mbaraka; a dançar e a fazer arte indígena, como cocar. Seguiu dizendo: "primeira coisa o jovem tem que pensar no futuro. Tem que saber trabalhar, argumentar, incentivar o jovem, psicologia". Ambos afirmam que querem mudar a imagem da aldeia.

Para começar, segundo a liderança: "a ideia é em um ano arrumar". Ele se refere a questões de roubo, espancamento e uso de bebida alcóolica: "a aldeia tá meio bagunçada". Para depois, reativar uma associação, que afirma existir em Sucurui'y, mas que está parada: "mas a comunidade até agora tá colaborando." Afirmou que lá não tem problema de arrendamento de terra.

Sobre as roças, o professor disse que quando a Funai liberar o combustível, eles vão fazer. O projeto da Funai é de um hectare por família. Seguindo a ideia de "mudar a imagem da aldeia", ele afirmou que "tá correndo atrás de advogado", pois, queria encontrar um caminho para plantar soja e milho. Ele sabe que segundo o MPF não poderiam fazer nem parceria, nem arrendamento e não pode ter transgênico e veneno. Mas, ele perguntou para 
um advogado terena como é que eles plantaram na aldeia de Dourados, que respondeu: "você não vai na cabeça do MPF porque MPF um dia ele defende indígena, outro dia ele julga. Porque aqui na aldeia a gente se reuniu tudo produtor indígena". Para ele, o procedimento seria conversar com a comunidade, fazer um relatório e fazer um termo com MPF pra justificar.

O professor achou boa a ideia de levar essas coisas para Sucurui'y, pois, eles querem "conquistar, achar o caminho pra plantar, plantar assim, individual e coletivo. Na aldeia seria melhor trabalhar coletivo. Porque individual cada um já tem seu pedaço individual". Ele relembrou que seu finado irmão em uma ocasião falou pro MPF:

eles queriam que o indígena plantasse só batata e mandioca. Mas nos
indígena tinha que acompanhar a tecnologia de hoje porque hoje em dia só
tecnologia. Claro que o nosso a gente não vai deixar de lado. Então, a gente
tem que acompanhar as duas bagagem, os dois barco. Aí o MPF não
respondeu nada. Porque pra plantar milho, soja tem que ter
acompanhamento da tecnologia.

Seguiu afirmando que quando tomaram posse não tinham dinheiro para adubar e tratar a terra, aí vieram as formigas. A terra está enfraquecida. Desde a posse a terra está parada. Ele que é filho do rezador, professor e liderança política afirmou: "nós queria achar um meio pra beneficiar. Pra ter um conjunto. O que a gente prometeu pra comunidade". Continuou com sua reflexão:

Tem o cacique que fica só pra ele. Tem o cacique que pensa com a comunidade. No meu mandato de 2000, eu falava pra comunidade: se encher meu barriga, vocês também vai encher; se eu passar fome, vocês também vão passar fome. Sou responsável. Só que nós queria achar esse projeto. Não é só nós que tá sofrendo. Toda aldeia tá. Eu fiz pesquisa: Caarapó, Porto Lindo, Lagoa Rica... a Funai diz que não tem dinheiro mas todo ano troca de carro e nós aqui sofrendo na aldeia, no dia-a-dia. A Funai é federal. Eu fiz pesquisa e quem mais tem dinheiro é Força Armada e Órgão Federal. Como é que cada aldeia tá passando precariedade, indigência?

Ele acredita que há uma questão que poderia fazer a diferença, trata-se da identificação da terra por etnia: "porque aldeia teria assim que colocar o nome dos kaiowá mesmo. Então, de cada aldeia tem que se pensar botar o nome do kaiowá. Se for dos kaiowá, exemplo, Sucurui'y, vai colocar: Aldeia Sucurui'y é dos kaiowá, depois pode colocar: da União Federal". Lá em Sucurui'y a maioria é kaiowá, mas tem alguns guarani. Eles não permitem que não-índio more lá, quem casar com algum tem que sair da terra indígena.

Em comparação com o antes e o depois da regularização, o professor acredita que melhorou: "porque antes a gente não tinha Posto de Saúde, não tinha escola. A gente sofria muito. Eu acompanhei a entrada, a posse". Na área central, seria construída a casa de reza, onde já havia sido reservada uma área para este propósito, mas a atual liderança, em conformidade, com os professores preferem que a casa esteja em um lugar mais calmo, 
pois, a proximidade da escola traria o inconveniente do barulho das crianças. Segundo o professor, o projeto da ex-liderança era de construí-la perto da escola. Mas, "agora na nossa administração a gente tá querendo mudar. Perto da escola é barulhento. A gente tá vendo um lugar específico pra isso. Tô vendo com meu pai pra levar dois ou três chiru pra cuidar. A madeira já tá pronto. Tem que correr prego, arame, sapé, transporte. Porque o pessoal daqui já sabe fazer". Mas teria que buscar sapé em outras áreas porque em Sucurui'y tem pouco. A liderança reforçou: "uma casa de reza é sagrada, respeitada, não pode fazer na correria pra não desabar em um ano e meio".

Em outro momento, conversei com o pai (rezador) e o filho (professor) embaixo de uma árvore na área onde vivem. Perguntei ao rezador, que tem mais de setenta anos, como era Sucurui'y quando ele era jovem. Ele respondeu: "esse aqui era tudo é mato, aí desmataram o fazendeiro alí. Desmataram bastante mato, desmataram, desmataram. Aí vieram de Brasília fazer pesquisa. Será que é verdade que o índio ocupou aqui? Alí morava mesmo". Referindo-se ao grupo de trabalho que fez os estudos de identificação e delimitação da terra.

"Fazendeiro judiá mesmo pra gente sair daqui", relembrou o rezador sobre a época em que lá era fazenda de gado. E, seguiu: "antes tinha mata, mas depois fazendeiro ganhou do governo e depois plantou tudo braquiária pra soltar vaca aqui. Aqui tinha bastante mato, pra lá um pouco do Corguinho tem uns 40 ha ainda tem mato alí. Esse aqui é nossa mesmo".

Prevalece em Sucurui'y a paisagem da braquiária, como herança das fazendas de gado. Algumas estruturas como currais e casas de madeira estão presentes em vários de seus espaços. A terra, depois da regularização em 2007, recebeu como passivo ambiental um vasto campo de braquiária. Antes das fazendas, prosseguiu o rezador:

a gente ocupava. Mas índio mesmo não para mesmo. Faz ogussu (casa grande) e depois largar. E de novo morar alí. Aqui pertinho tem rio. Rio Brilhante. Rio mesmo pra pescar alí. Quando saiu daqui, índio foi pra lá. Morar cinco anos por aí. E procurar de novo, outro lugar. E vai indo. Aí morava "Pita Alegre", alí. E morava pra alí. Sidrolândia. Todo esparramado índio morava pra cá. Até no Pirakuá, Ñanderu Marangatu, Campestre. Índio não para mesmo. Pra cá tudo índio guarani e kaiowá. Pra lá terena, kadiweu, guató. Eu tenho história pra contar. Se contar, você sai de noite daqui.

Segundo o rezador, o nome Sucurui'y vem do rio, que passa na terra indígena, onde há muita sucuri. Ele disse que na mata tem onça, cateto, tamanduá bandeira, macaco e bugio. Pai e filho falam das carnes de caça que já comeram e da saúde dos indígenas que comem só carne de caça. O rezador relembrou que caçava e "era uma festa caçar. Antigamente, tinha que rezar pra matar bicho: queixada, veado, quati, tudo bicho. Quando entrar no mato. Pra sorte". O filho complementou: "se for de manhã, já faz reza de noite. E quando entrar no mato faz reza". Ele quer aprender a reza do milho com o pai. E acredita que "leva uns dois meses pra aprender. As pessoas mais velha trabalha a linguagem do 
nosso mundo. $\mathrm{O}$ avô do pai tinha acesso com Ñanderu. E por isso que crente tirou o xérox de Ñanderu". Ao que o pai, disse: "já me falaram pra eu virar crente. Eu disse não. Minha cultura é Ñanderu". O filho confirmou: "nós somos família de Ñanderu".

Eles querem construir a casa de reza. Mas não têm chiru, por isso, o rezador vai pedir um deles para os rezadores de Panambizinho. Disse que vai rezar direto. Perguntei se existe reza para acabar com a braquiária. Ele respondeu: "não tem. Não tem jeito". Então, como fazer para tirar a braquiária e a terra nascer de novo, as coisas da terra daqui? "Só acabar mundo e Deus esse aqui terra vai virar. Terra nova. Mato novo. Acaba pessoa, acaba mundo. Faz tudo novo. Pessoal novo. Terra novo. Mato novo. É o que vai acontecer". E prosseguiu com seu pensamento: "o mundo pra acabar é difícil. As pessoas sim, o mundo não. Vai acontecer". Perguntei se Ñanderu falou alguma coisa para plantar aqui na terra para que os bichos voltem. Ele revelou: "bicho tem mesmo. Mas o dono escondeu. O Jara. Aqui mesmo tem. Mas tem que deixar o dono do bicho. Que não tem mais mato aí o dono do bicho esconde. Cada bicho tem um jara. Cada planta tem. Pedra também”.

Seguimos conversando e the perguntei qual seria o melhor caminho pra ser kaiowá legítimo. Ele disse que passa pela cultura: "não pode largar cultura kaiowá legítimo. 0 caminho é um só. Não pode largar. Se pegar outro caminho, já errou. Segurar nossa cultura". Ressaltou a ligação muito forte dos kaiowá com a terra, o mato e a comida: "antigamente, kaiowá comia carne de bicho. Mato tinha bastante. Acabou o mato, o dono do bicho escondeu tudo. Antigamente, comia só carne de bicho". O filho fez uma correlação entre a cor da pele e da terra: "na pele dos kaiowá puro você vai olhar na pele e na terra".

Eles adotam uma classificação de remédio conforme os ecossistemas existentes na sua terra: remédio do mato, do brejo e do campo. O rezador afirmou: "eu sei tudo. O pessoal não me procura muito porque tem doutor". E confirmou que mesmo tendo pouco mato ainda são encontrados remédios: "se sabe, acha. Sabendo acha". Ele compara a procura de remédio com o tatu, que se enfia no buraco, mas buscando, o encontra: "é preciso saber procurar e curar doença. O remédio acompanha com a reza. A reza não pode largar. Acompanha o Mbaraka. Cura mesmo doença, por isso que eu não vou largar o meu Mbaraka. Até o branco vem buscar rezador, remédio caseiro. Remédio não é brincadeira". Mas em Sucurui'y: "só não tem do campo. Esse encontra nas fazendas, lá encontra guavira. Aqui mesmo não tem guavira". Então, remédio do campo, teria que buscar fora da terra indígena.

\subsubsection{A escola: onde as sereias povoam a imaginação}

No primeiro dia de visita a Sucuruíy, comecei meu trabalho pela escola. Inicialmente, estiveram na sala de reunião da escola duas professoras, o professor e a liderança para 
uma conversa prévia durante o intervalo das aulas. Depois, as duas professoras voltaram para a sala de aula com seus alunos e eu segui por algum tempo conversando com 0 professor e a liderança até que elas voltassem.

Um dos assuntos preferidos deles gira em torno de plantas, de remédios do mato e de comidas através do que se pode ou não fazer de acordo com a cultura; de como o aprendizado é repassado a partir do momento em que se pergunta sobre algo e da importância de se perguntar aos mais velhos, já que eles têm mais conhecimento. A mesma lógica persiste para os processos de cura, ou seja, quem necessita deve buscar a orientação com quem tem o conhecimento devendo ter a crença de que o rezador vai indicar o tratamento com o remédio e a reza adequados. Creio que foi por isso que eles me contaram tantas histórias, já que disse que o meu interesse era a relação deles com a mata e a terra.

O professor disse que sempre fala para os seus filhos e alunos que os indígenas idosos devem ser procurados pelos mais novos: "é obrigação dos mais novos procurarem os mais velhos, porque eles são arquivo. Vocês tem que chegar nos rezadores porque os mais velhos tem arquivo, tem muito conhecimento. Conhece remédio sabe tudo das coisas". A função do estudante é procurar e fazer pesquisa, pois, se não fizerem isto, os rezadores não vão passar o que sabem.

Ele mesmo é curioso, já fez pesquisa com a rezadora sobre linguagem e passou para os alunos. Com o seu pai, que é rezador, vai aprender o batismo do milho. E prosseguiu: "o idoso tem conhecimento da parte espiritual. Tem arquivo de esclarecer o que é bom, remédio, cântico". Comparou o conhecimento do pai com o do doutor, ou seja, sabe o cântico, a reza, o remédio certo pra cada situação. A liderança reforçou: "agora tá dependendo $100 \%$ do médico. Mesmo se tá pra morrer. Os médicos acusam o rezador. Só que o rezador acredita no espírito da pessoa que faz a reza".

Liderança e professor se dizem indignados quando os mais jovens não respeitam os mais velhos. E que essa situação também acontece na cidade. A liderança ensinou aos filhos: "de véio e de morte não tem como escapar, é o futuro da gente". E seguiu afirmando: "a cultura dos indígena é muito rico. A gente que não tá percebendo, né. Eu respeito qualquer tipo de pessoa".

A escola atende alunos do ensino fundamental, da $1^{\underline{a}}$ a $5^{\underline{a}}$ séries. Da $6^{0}$ série em diante, os alunos que continuam seus estudos são direcionados para as escolas municipal ou estadual em Maracaju. São quatro professores, sendo um professor e três professoras, destas, duas concluíram o Teko Arandu. O professor disse que quer prosseguir nos estudos, inclusive, na ocasião da pesquisa havia feito o Enem e iria tentar o Teko Arandu. As professoras não são nascidas em Sucurui'y, mas devido ao trabalho na escola passaram a 
morar nesta terra. Mantive uma interação com três deles numa das salas da escola, junto com a liderança. Segundo a professora 1:

Nessa terra tá muito degradada, quando o pessoal planta, aí não tá
nascendo mais de acordo com o tamanho das plantações porque a terra tá
muito seca. Eu me preocupo de que lado a gente vai conseguir pra
revitalizar de novo essa terra. Principalmente, aqui nesses 65 ha. Tá tendo
muita formiga cortadeira. Quando a pessoa planta algumas coisas, não
colhe porque a formiga vai lá e ataca e por causa que não tem de onde
achar.

A terra não tem histórico de instituições que tenham feito parcerias e projetos para a realização de algum trabalho ambiental na aldeia ou na escola. Mas conforme a professora 1: "a gente passa pros nossos alunos de que jeito eles devem utilizar a terra. A gente sempre esclarece que a queimada traz prejuízo. Agora mesmo vai chegar à época da seca. Esse é que é o problema: a queimada".

Agosto, mês da seca e dos ventos, é quando aflora com mais tenacidade o fogo dentro das terras indígenas. Fenômeno verificado também na beira das rodovias, nas fazendas e nas cidades, onde muitos têm o hábito de queimar lixo, mesmo quando dispõem do sistema de coleta.

A queimada interna se espalha pela braquiária. A professora 1, denunciou: "aí quando a pessoa não tá bem conscientizado mesmo, queima. A gente briga mesmo. A gente chama o bombeiro. O cacique chama o bombeiro. Questão de saúde. Começa a vir as doenças respiratórias, diarreia. E com isso vem tudo".

Sobre o lixo da região central, a professora 1 esclareceu que: "o pessoal da saúde deixa o saco, bag". Complementou a professora 2 sobre o serviço de coleta da prefeitura: "no começo eles deixavam e depois eles recolhiam. Agora não. Acho que depois que o prefeito mudou, parou também, de fazer a coleta". Agora não tem mais: "cada um assim quando o lixo tiver bastante, queima ou faz alguma coisa. Antes o carro vinha pegar e levava pro lixão. O caminhão vinha pegar cada casa. Faz tempo. Eu mesmo tinha bastante lixo, aí eu tive que queimar, né". A queima do lixo por unidade domiciliar parece ser a regra, como mostra a fotografia a seguir.

A professora 1 estudou ciências da natureza pela FAIND/UFGD e lá conheceu através do curso uma experiência de sistema agroflorestal no distrito de Itahum, pertencente ao município de Dourados, pelos assentados e verificou que eles colhem tudo plantando debaixo da árvore, como milho, batata doce e tomate. Ela arrematou: "e de lá eles tiravam o seu sustento, num espacinho assim pequenininho. Esse sistema é que eu queria plantar aqui. Só que eu não tenho como começar. Porque a gente não tem semente, essas coisas pra gente começar, né". A sua intenção seria: "fazer um projeto experimental pra incentivar a comunidade a plantar". Ela fez um teste em sua casa ao plantar abacaxi na sombra de uma 
árvore. Segundo seus resultados: "até o aroma é diferente. Revitaliza. E tá dando. Não vai nenhum agrotóxico".

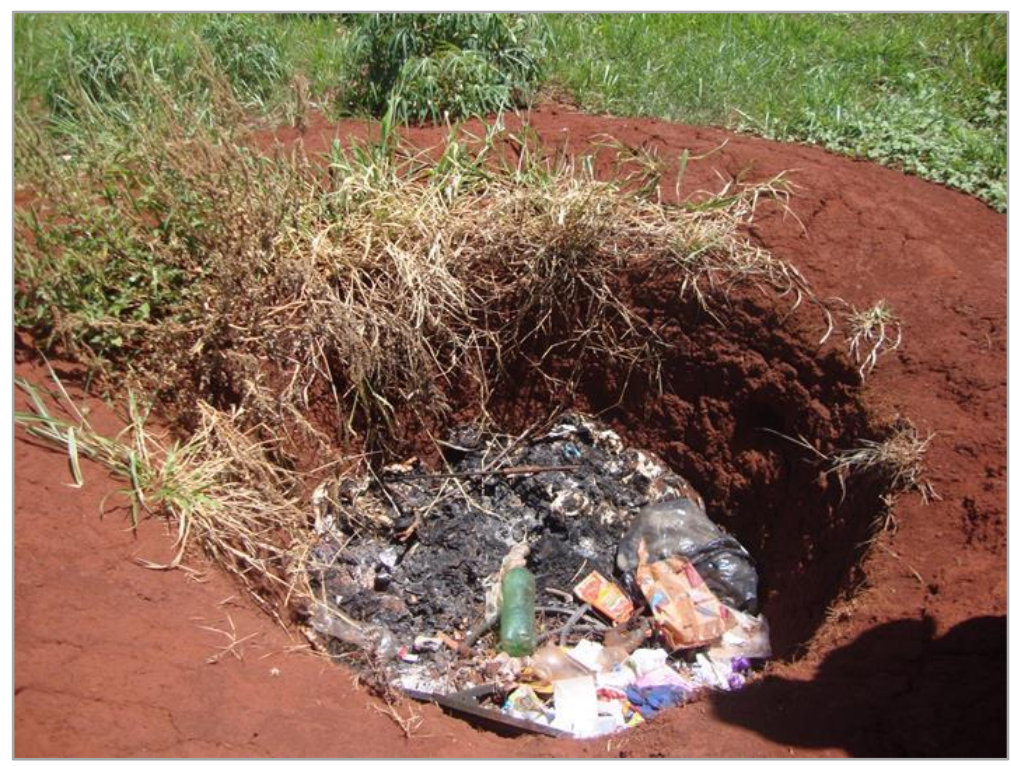

Fotografia 24 - Queima de lixo.

Fonte: Autoria própria.

A professora 1 refletiu que nas terras indígenas havia muitos recursos naturais. Mas os fazendeiros começaram a cortar e a vender madeira. Quando ocorreu a regularização, como foi o caso de Sucurui'y, a terra foi entregue muito destruída: "e pra gente começar do zero de novo é muito difícil". Foi uma herança de uma terra degradada que tem muitos problemas, como a formiga cortadeira, que se prolifera por não existir mais a mata, por isso ela: "vai comer o que você planta. Essa é a realidade, não é só aqui também". E concluiu: "o único problema que temos aqui são as terras degradadas".

Sobre o uso da mata, às vezes são feitas visitas com os alunos através da escola. Nem todos sabem andar por lá. A professora 1 reconheceu que na mata: "a gente tem os recursos aqui, mas tem que saber usar para não acabar. Tem que saber proteger os animais também, né. Até as árvores nativas”. E lembrou que em Sucuruiý tem nascente com árvore nativa que protege. A professora 2 complementou: "nesse mato tem muitos remédios". Sobre esse tema, ela revelou: "uma vez eu fiz um trabalho sobre remédio caseiro com meus alunos e a maioria sabe porque os pais usa".

Mesmo na braquiária encontram-se folhas e flores que servem para fazer remédio. $\mathrm{O}$ professor confirmou: "remédio tem na braquiária. Se você não souber, pisa, vai meter fogo, vai queimar porque você não sabe. No brejo, a maioria tem remédio medicinal, tradicional, mas tem que respeitar. E no matão, tem remédio, tem na árvore".

Eles são unânimes em afirmar que para a maioria das plantas e árvores não sabem o nome correspondente em português. O que às vezes gera alguma confusão. Por isso, 
sempre que podem, procuram conversar com os mais velhos, com seus pais para tirar dúvidas e retransmitir o conhecimento para seus alunos. A professora 2 descobriu quando a sua mãe foi visitá-la que havia muito remédio no brejo. E falou com espanto: "pra mim era só um brejo". A partir disso, falou para os demais da família não deixar ninguém tocar fogo: "eles protege agora, o brejo, tem bastante". Mas a liderança ressaltou:

remédio de brejo agora tá muito difícil porque a maioria toca o brejo e planta arroz e aonde que a gente vai achar o remédio caseiro. No lugar onde tem remédio, eles metem lavoura, a cana. O remédio some tudo. Por isso, os guri das família indígena, hoje em dia, quase não conhece mais os remédios. Porque os lugares onde tinha remédios caseiros não se acha mais. Você vai lá e só acha um pé de soja, vai achar um pé de cana, arroz, essas coisas, milho, mas remédio é difícil. Tendo a braquiária você vai caminhando, se você não conhecer os remédios, você vai pisando em cima. Agora se você vai caminhando e oiando a parte que você conhece os remédio qualquer folhinha que vai parecendo você diz que é um remédio.

O grupo se divertiu ao falar das espécies existentes na mata, como chiru, angico e canafístula. A liderança falou: "eu conheço vários remédios, mas no meu idioma. Pra explicar pra uma pessoa assim, eu já não entendo muito." Ele citou o exemplo do guacuri, que seria o limãozinho do mato. Mas, há uma dificuldade dos mais novos saberem os nomes e a serventia das plantas, pois, se o pai não souber o nome não poderá ensinar para os filhos, na sua visão. Os professores são muito curiosos e empenhados em aprender. A professora 1 contou que sempre nas visitas à mãe, que mora em outra terra, procura aprender algo. E reconheceu:

$\mathrm{O}$ conhecimento da nossa mãe tem bastante. A gente que não valoriza, às vezes. Isso que às vezes eu falo pros meus alunos. A gente tá trabalhando sobre lenda indígena, depois vai ser folclore nosso. Então, eu contei pra eles várias histórias, pra que eles pudessem um dia contar também pros filhos que vão vir. Se nós mesmo não contar, os pais não tá sabendo, se os avós estão se perdendo, assim também o nosso conhecimento sobre remédio tradicional.

A professora 1 revelou que interaje sempre com sua mãe no sentido de compreender que não é somente a planta, a árvore, o animal e, sim o conhecimento que se tem deles. Então, para protegê-los seria necessário utilizar a sabedoria a favor e repassar para os demais, principalmente, os mais jovens. Ao que ela confirmou: "repassar para os demais. Se não repassar também acaba". E, seguiu contando uma narração da sua infância:

quando eu era pequena meu pai contava um monte de história e eu não levava a sério. E agora que eu tenho que perguntar de novo pra ele pra passar pros meus alunos. Às vezes as crianças começam a questionar, como é isso? Se você não souber, não vai passar. Você tem que ser um bom pesquisador. Quando eu vou pra casa dos meus pais, eu vou perguntar pra eles porque o tamanduá tem olhinho pequeno. Ele já contou essa história, mas tô esquecendo. Então, vou trazer pros meus alunos.

Todos falaram como foi importante à realização do Aty Guasu das Mulheres em Sucurui'y, entre os dias 25 a 29 de junho de 2014 para que os alunos pudessem vivenciar 
algumas práticas que são estudadas na sala de aula e para muitas mães tirarem dúvidas sobre a criação dos seus filhos de acordo com o conhecimento da cultura kaiowá-guarani. A professora 2 relembrou do entusiasmo do seu filho ao ver o uso de alguns instrumentos como o Mbaraka, pelos homens e da Taquara, pelas mulheres. Na ocasião, só três mulheres usavam a Taquara: a esposa de um rezador importante da reserva de Dourados; outra de Panambizinho e a mãe da professora 1. São as mulheres que conhecem o sagrado. Por isso, ressaltaram que houve um grande aprendizado pela Aty Guasu.

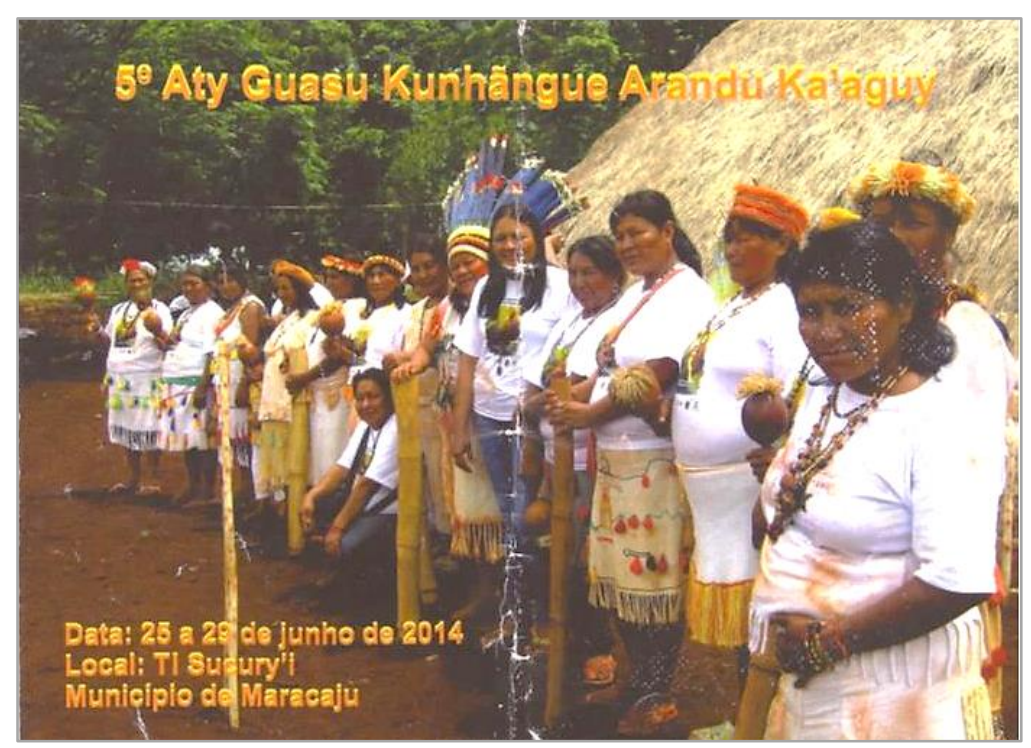

Fotografia 25 - Cartaz do 5ํA Aty Guasu Kunhãngue Arandu Ka'aguy. Fonte: Autoria própria.

A professora 2 contestou algumas lideranças que permitem a mulher pegar 0 Mbaraka. Ela os chamou de "cacique moderno". Já a professora 1, que também concorda com ela, denominou tais lideranças de "pirata", pois, haveria, nesse caso, um desrespeito a aspectos da cultura. Muitas crianças que hoje estudam em Sucurui'y vêm de famílias que moravam em fazendas, em acampamentos perto da estrada e de outras terras indígenas. Muitas chegaram sem saber falar direito o guarani. E as famílias não sabem muitas coisas da cultura.

A professora 1 narrou um caso em que uma mãe foi perguntar para ela qual a alimentação adequada para a filha que estava virando mocinha. Ao que ela respondeu: "tem que tirar a carne pra ela não ficar epilética. A mãe não sabia disso. Essa é a realidade. Comigo aconteceu, com a outra professora aconteceu. Nossa mãe tirou de nós. Por isso, nós somos gordinha. É da cultura".

A professora 2 esclareceu que até o segundo ano escolar as aulas são apenas em guarani. A partir do terceiro (até o quinto) é bilíngue. Um aluno ensina ao outro o guarani para aqueles que só falavam português. Porque os que vêm de fora falavam com palavras 
misturadas em português e guarani na construção das frases. A professora 1 completou: "essas crianças eram muito distante do conhecimento indígena. Depois que a gente começou a trabalhar sobre cultura, mito, lenda e eles já estão começando a diferenciar. Agora tó falando pra eles sobre lenda indígena, que mito é realidade. Só que a gente tá esquecendo".

Para o grupo de professores, o não-índio coloca o mito como se fosse uma fantasia ou inverdade ${ }^{98}$. Seus alunos já se posicionam, como atestou a professora 2: "quando a gente fala assim pra eles mito, eles falam ao contrário. Não é mito professora, é verdade. Eles colocam a verdade mesmo assim. A maioria vem de casa, a gente só reforçou mesmo. Eles já sabem".

E para reforçar o conhecimento do mito, os rezadores colaboram com a escola. Um dos rezadores é pai do professor e a rezadora é tia da professora 1. Sobre esta, sua sobrinha afirmou que, apesar da idade, ela é muito disposta: "se precisar, ela vai pra Aty Guasu. Vai à pé para a cidade, já foi para São Paulo e para Brasília para defender seus direitos. Ela é muito sábia". A rezadora recebe muitas visitas de gente que vem da cidade. Ela faz remédio, reza e batiza, dando o nome em kaiowá, pois, quando a criança fica doente, tem que chamar pelo nome. O filho da professora 2 teve o filho batizado por ela. $A$ professora 1 revelou que a rezadora: "não gosta dos evangélicos da Deus é Amor, porque disseram que ela é demônio e também porque essas igrejas tão cada vez mais espremendo ela e põem um som muito alto".

$\mathrm{Na}$ visita que fizemos com a professora 1 e seus alunos, ao redor da lagoa foi possível visualizar várias plantinhas "escondidas" por debaixo do vasto campo de braquiária, onde também prevalecem os montes de formiga cortadeira, como mostra a fotografia abaixo. Esta professora gostaria de fazer horta, compostagem, adubo orgânico e reflorestamento, inclusive com árvores frutíferas, com os alunos. Há uma dificuldade em se conseguir mudas. Ela comentou que fez dois anos que a Funai levou trezentas mudas (de jabuticaba, pitanga, jatobá, dentre outras) que foram plantadas no entorno da lagoa mas, os moradores do entorno fizeram queimada. Mas, mesmo assim, ela conseguiu identificar algumas mudas que resistiram ao fogo.

Havia alguns pés de guavira no meio da braquiária. Por isso, ela alertou para os perigos da queimada: "acaba destruindo outras espécies, como plantas medicinais, que ainda resistem enquanto que a braquiária sobrevive ao fogo". Na proximidade da lagoa

\footnotetext{
98 "O mito é considerado uma história sagrada e, portanto, uma "história verdadeira", porque sempre se refere a realidades". (ELIADE, 1994, p. 12). Mas existem aspectos negativos que são associados ao mito como: lenda, falsidade, insuficiência, ingenuidade, não cientificidade, não-rigor e engano. "Em ambos os casos (engano ou mistificação), o erro é de quem decifra, não do mito. A ambiguidade da linguagem que utiliza decorre da plenitude do simbólico, não da sua insuficiência" (CÉSAR, 1999, p. 38-9).
} 
existem várias áreas de brejo e uma matinha onde há uma "lagoazinha", que segundo a professora é a morada das sucuris. Essas áreas se comunicam com a lagoa maior, alimentando-a. Lá podem ser encontrados os remédios de brejo, que para a professora: "quem sabe e confia no remédio caseiro vai direto pegar, senão vai no postinho".

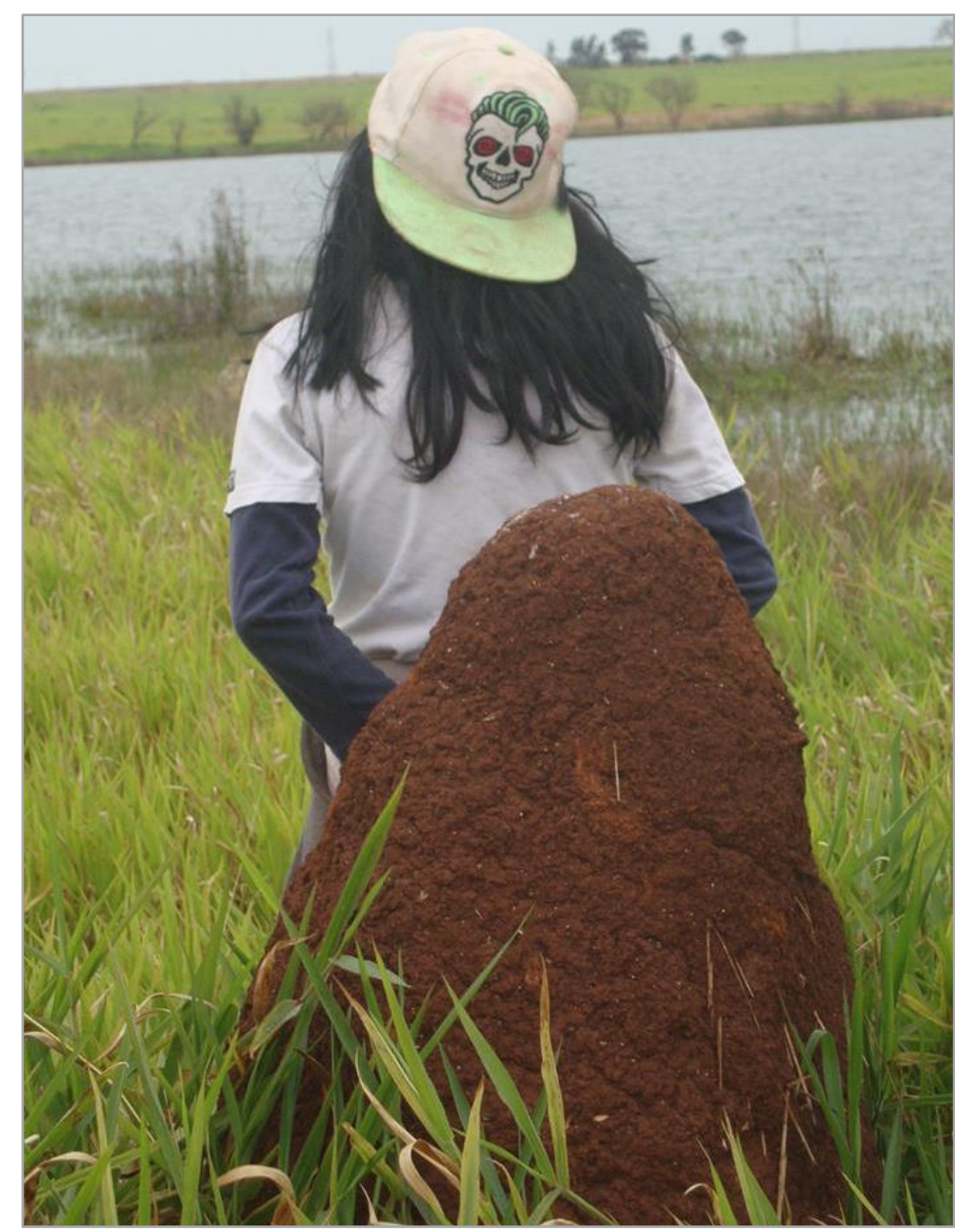

Fotografia 26 - Formigueiro pedra

Fonte: Autoria própria.

Sobre as formigas, ela disse que se lá tivesse tamanduá bandeira, ele comeria o cupinzeiro. Sua ideia seria plantar, novamente, árvores para recuperar toda a mata ciliar em torno da lagoa. Ela disse que antes da sua chegada a escola: "o pessoal de lá jogava garrafa e lixo na lagoa". Mas lá ainda podem ser vistos capivara, jacaré e falcão que pesca peixe $^{99}$. A comunidade costuma ir a lagoa pescar, geralmente, com vara de bambu até a

\footnotetext{
${ }^{99}$ Em 2013 quando fiz o trabalho de campo prévio, o professor contou sobre a caça de capivara, que segundo ele, foi promovido por assentados de um acampamento situado as margens da BR 267, que liga Maracaju a Dourados, ou seja, ao lado de Sucurui'y. Segundo ele, as invasões de sem-terra e de gente da cidade para caçar os animais fizeram com que a quantidade de capivaras diminuísse, pois, antes eram trinta. Depois desses episódios a comunidade se reuniu para proibir.
} 
cintura e alguns poucos tem barquinho de madeira para pescar mais ao fundo da lagoa. Uma das crianças disse que pesca com os pais e depois comem o peixe: "é divertido".

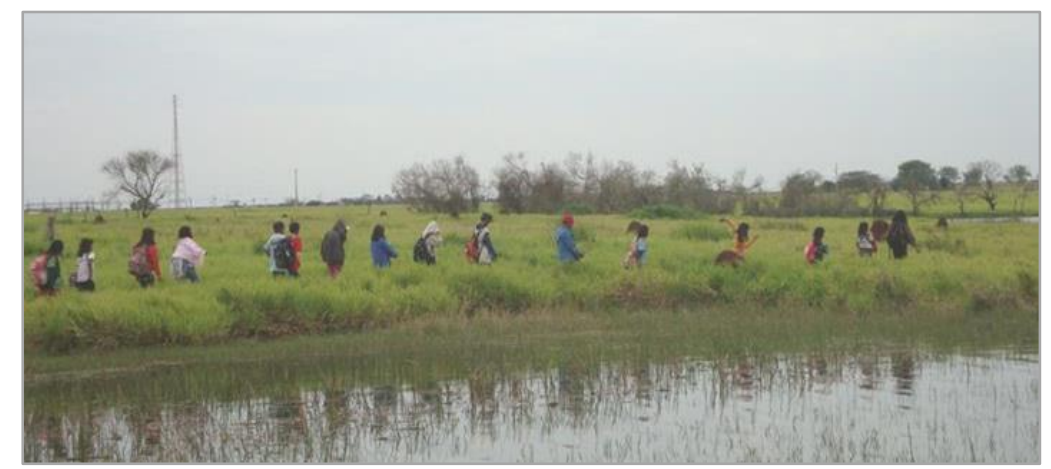

Fotografia 27 - Caminhada na lagoa. Fonte: Autoria própria.

O lugar, apesar de ter seus "problemas ambientais", é bonito e exerce uma função importante para a comunidade que o utiliza para: pescar, tomar banho e recreação. E a escola, para fazer várias atividades didáticas. A professora 1 disse que sempre leva seus alunos, que os chama de "filhos", no final da tarde para que possa contar estórias e eles, desenham com base nas atividades desenvolvidas. É o que demonstra a imaginação das crianças através dos desenhos que enfeitam as salas de aula, inclusive com sereias no lago, conforme fotografia.

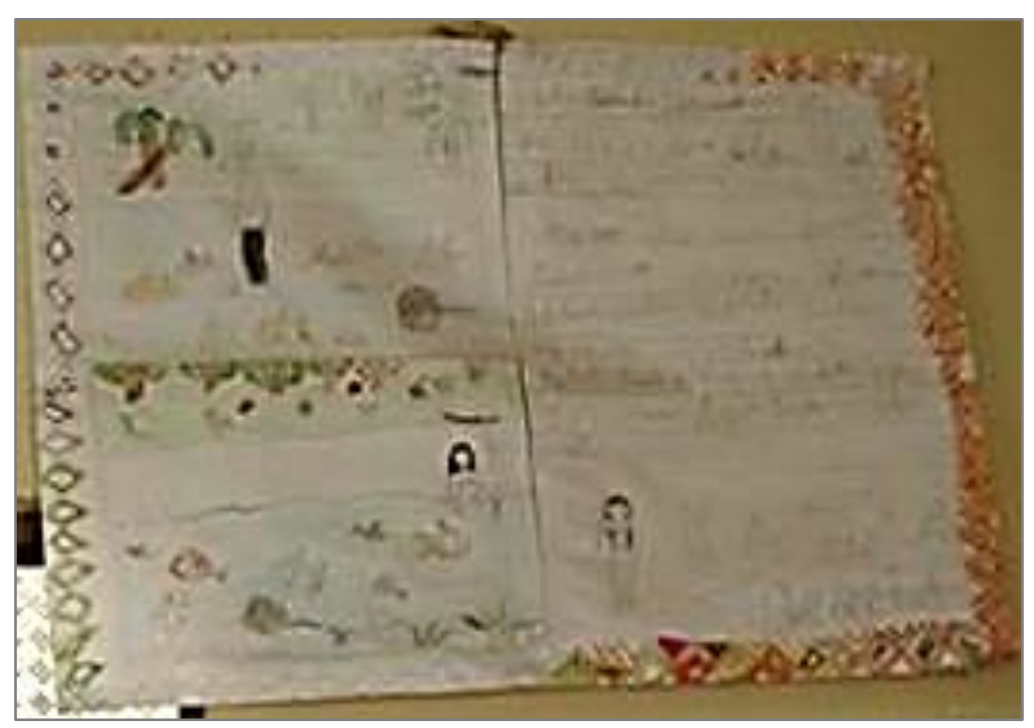

Fotografia 28 - Desenho de sereia.

Fonte: Autoria própria. 


\subsection{VIVENDO O MITO}

Esta parte é dedicada a um casal de rezadores que vive em Sucurui'y. Eles não são nascidos lá, mas participaram da retomada da terra. Passamos todo um dia conversando e foram extremamente amáveis. A maior parte da minha escuta girou em torno da formação e da compreensão cosmológica kaiowá-guarani do rezador, que na ocasião tinha sessenta e cinco anos. Ela, de setenta e oito anos, por sua vez, é uma respeitada rezadora e fazedora de remédios. Considerada como uma das mulheres poderosas de reza pelos kaiowá. Durante o tempo que passamos juntos, não lhe faltaram visitas em busca de cura, inclusive de muitos não-indígenas.

Ambos se conhecem desde 1988. E nas conversas, eles vão entrecruzando as histórias das suas vidas. Ela acredita ter direito a uma terra em Cerroí, no município de Guia Lopes. A busca por esta terra constitui uma verdadeira odisseia. Contam que já viveram na cidade, mas se empenharam em ajudar a retomada de Sucuruíy. Então, segundo o rezador: "aí nós viemos e ajudemos pra valer. Eu dizia que a aldeia vai acontecer pra valer. Eu era novo na reza. A turma não confiava muito em nós. Aí eu convidei Jaguapiré, Porto Lindo, Paraguasu, Caarapó... Trouxemo uma turma aqui pra ajudar nós. Reunimos uns 300 índios". Desde então, eles permaneceram em Sucurui'y.

O rezador ${ }^{100}$, que já foi ervateiro, reconheceu que a companheira tem mais conhecimento que ele: "eu aprendi com ela um bocado de coisa como trabalhar". Mas que os dois aprenderam juntos várias coisas. E, complementou: "tem que ter um rezador pra soprar no ouvido da gente pra aprender, pra não esquecer daquela palavra”. Ele começou seu aprendizado sobre o sagrado em 1992. Depois de narrar vários episódios da sua vida, disse: "eu virei conhecedor da história. Conheci muita história, mas queria conhecer mais ainda. Cada vez querendo conhecer mais". Para ele cada história tem um número e elas não estão escritas no papel.

A rezadora ${ }^{101}$ revelou como proceder para extrair remédios de árvores: "chega num pé, tem que rezar pra poder valer. Fazer rezar. Saber raspar. Não pode chegar na pele da madeira. Depois aferventar, tem que rezar de novo. Tomar o remédio, só isso vale". Sobre a relação com as árvores ele indicou como deve ser o diálogo ao se dirigir a elas: "árvore eu confia muito de você. Eu vai tomar esse remédio, com certeza, o deus vai te abençoar, vai me abençoar eu também. Vai abençoar todos nós. Agora tô tomando isso aqui pra me curar.

\footnotetext{
100 Ele nasceu na região do município de Douradina e quando tinha nove anos de idade foi para região de Ivinhema. Com doze anos, um tio o levou para colocar o tembetá, em Panambizinho (para ele, hoje em dia não se faz o tembetá, pois, "se for fazer tem que criar o sagrado". A rezadora completa: "não usa mais. Porque agora tudo é irmão, crente. Antigamente não tinha irmão, igreja, nada"). Ainda jovem, os pais e os cinco irmãos morreram todos de tuberculose. Ele ficou "solito", sem parente. Revelou: "a minha luta foi pra viver. Levar a vida". Seu padrinho, um baiano, tinha uma fábrica de farinha, então, foi aprendendo a trabalhar com ele.

${ }^{101}$ Ela nasceu e cresceu na reserva de Dourados. Aprendeu a rezar com o pai e a mãe.
} 
Pronto. Amanhã tá curado. Dor de cabeça. Tontura. Saiu tudo". E, assim, os dois passaram a trabalhar juntos nas questões espirituais.

Ele passou pela experiência de ter ficado doente e quase cego quando tinha dezenove anos. Isso o fez se aproximar do mundo espiritual. Ele trabalhava em uma fazenda perto de Ponta Porã. Um paraguaio que morava lá o levou até uma benzedeira, que o curou. Ela revelou que seu caminho era para trabalhar pelo espiritual.

Seu aprendizado começou quando conheceu seu mestre indígena, chamado Kati, que o encaminhou para um lugar na tríplice fronteira (Brasil, Paraguai e Argentina) e, inicialmente, passou um ano na mata. Então, primeiro, ele começou a aprender sobre o mato, sobre como conversar com ele. Seu mestre orientou: "pra você matar passarinho tem que rezar. Não mata sem rezar. Tudo isso ele passou pra mim como eu posso conseguir alimentação". Depois do período de conhecer as coisas do mato, prosseguiu o ensinamento para aprender a rezar: "rezar mesmo pra você conhecer o espírito. Eu sentia medo". E o mestre o incentivou: "é pra você criar coragem mesmo. Você vai ver até a sombra do humano". Passou mais um ano na mata: "fui rezando. Ele mandava espírito. O primeiro espírito que chegou lá não conversou comigo. Na segunda vez, conversou". Perguntou o nome do espírito, que disse: "nós somos do pai do mato. Depois do pai do mato, você vai conversar com o pai do vento. Depois do pai do vento, você vai conversar com o pai da lua. Depois do pai da lua, o pai do sol". E prosseguiu: "humano destruiu nosso mato, destruiu nossa coisa. Porque gente branca chegou e foi desmatando".

O mestre o indagou: "você já melhorou ou não? Agora quero ver teu trabalho". Ao que ele fez uma demonstração com folhas de ervas da mata. E o mestre concordou: "isso mesmo. Então você vai conhecer resultado do remédio da madeira como funciona". Foi chamado o espírito da floresta, mas ele não tinha mais medo. Nesse momento foi esquecendo dos sofrimentos e da morte da família: "eu tava solito ${ }^{102}$ mas eu criei coragem".

$\mathrm{Na}$ sua narrativa, enumerou cada estória dos pais da floresta, do vento, da terra, da água, do rio e outros como se fosse uma função. E foi contando, em sequência, seus aprendizados sobre cada um deles. Por exemplo, o pai da floresta é o número um.

Sobre o pai do rio, conversou com ele para pescar, pois, gosta de flechar e de comer peixe assado. O pai do rio falou para ele: "você quer pescar? Tem que fazer a reza pra pescar e a simpatia pra acertar". O rezador mostrou o seu arco e flecha e desenhou no chão o corpo do peixe, mostrando onde se pode flechar. Com seu aprendizado passou a reconhecer peixe de verdade, natural e original, pois, existe peixe pirata, que dá doença: "o peixe é uma coisa de Deus. Igual nós somos humanos. Todo humano é coisa de Deus. Então, o peixe é mais sagrado. O peixe bom não é arisco. Se é pra matar, já vem".

\footnotetext{
${ }^{102}$ É comum na sua comunicação misturar palavras em espanhol na sua fala em português, além do guarani.
} 
Quando seu mestre Kati falava, o rezador ficava sempre quieto, respeitava a palavra dele. Ele sempre repetia que: "tinha que acreditar mesmo. E depois o resultado aconteceu". Falou sobre o respeito à água: "porque o humano devemo respeitar a água. Ligar com o pensamento do pai antes de tomar a água. Muita gente morre de enfermidade. A água dá doença".

Sobre o pai do mato colocou assim: "humano não conseguiu acabar o mato por conta da reza. A vontade dele é acabar o mato. O guerreiro profissional do mundo é o branco, europeu, que queria acabar o mato e o humano pobre. O pai do mato, reza pra nós viver". Para ele, o humano pobre não pode acabar, pois, são os salvadores do mundo. Perguntei: quem são os humanos pobres? Ele respondeu: "todos nós somos pobres e trabalhador. Quem faz a construção do mundo é gente pobre: construção, ponte... a gente rico de dinheiro, estudou. Trabalha só no papel". E, prosseguiu: "gente rico enfiou no país: colocou veneno, colocou a cana, colocou o açúcar, que era pra saúde, depois veio bebida alcóolica". Outro problema identificado por ele são os remédios dados para o gado estufar porque isso transmite doença, engorda a pessoa com a carne gordurosa e engrossa o sangue: "a gente dura pouco. Isso foi o humano rico que criou isso. Deveria criar o animal naturalmente".

Para o rezador, depois de muita luta para retomar Sucurui'y e de inúmeros despejos com os ataques dos fazendeiros, tem que: "cuidar da aldeia pra conseguir uma coisa maravilhosa. Aldeia tem que cuidar bem cuidado pra servir muito tempo". Mas existem problemas em Sucurui'y e, enumerou: "índio falso entrou aqui dentro. Índio que não é original, pirata. O branco mesmo que se transformou como índio. Aqui já veio um desse. Hoje ele mora na cidade. Evangelho falso também. Mas existe evangelho de verdade".

Perto da casa deles, plantaram um mandiocal. O rezador percebeu que: "tava muito bonitinho. Aí veio a chuva, a raiz de mandioca apodreceu tudo". Depois, entendeu que precisava fazer valetas para a água da chuva correr e também botar calcário para corrigir o solo. E refletiu sobre a situação da terra:

Hoje tá matando a terra. Quando a terra morre, enfraquece. Pode plantar tudo aqui e amanhã depois tá tudo amarelo, não dá colheita, acabou. Então, pra fazer plantio pra devolver mesmo, agora tem que ter mistura. Mistura com calcário, calcário e gesso. Com certeza que vai dar um bom colheita. Precisa recuperar. A qualidade. Isso que toda aldeia precisa.

O rezador falou da origem da comida, sobre o pai da comida. A terra estava pronta só não tinha semente pra plantar: "aí o pai do mato resolveu. Quem colocou a comida foi o pai da comida, que a trazia na roupa. Se apresentou como pele, mas era roupa, onde trazia as sementinhas. O pai da comida colocou tudo: comida pra humano, pra pássaro, pra o bicharada do mato". O rezador observou que hoje pouca gente reza ao comer:

Quando vai comer, a comida tá pronta na mesa todo mundo tem que rezar. Quando acabou de comer, todo mundo tem que rezar para despedir da mesa. O pai da comida colocou isso. É um respeito pro pai, pra não deixar 
nada faltar aqui na terra. Porque se o pai olha por nós e a gente não obedecer àquela palavra, talvez hoje planta coisa e não dá pra colher. Planta, planta, mas não colhe. Então, o pai sempre fala ter que obedecer. Levar o pensamento do pai da comida.

Sobre a relação com os animais de caça que servem para a alimentação, disse o rezador: "vai na floresta pra matar pra comer tem que rezar pra trazer pra casa. Tem macaco que não serve pra comer. Serve pra comer o macaco amarelo, o quati, o bugio pequeno, paca, cotia, mateiro. Então, a gente faz reza pra trazer comida pra casa". No caso de animais domésticos, como galinha, porco, cabrito, carneiro e vaca, quando se vai pegar um animal para comer:

não pode falar assim: vamo matar galinha. Assim não serve não. Por exemplo, amanhã vamo matar galinha, escolhe três, mas não diz qual a que vai matar pra fazer comida. Não chegar e correr atrás da galinha, que ela grita. Todo bicharada da casa considera a mulher como mãe e o homem como pai. E pede socorro: pai não me mata, por favor. Então, a gente mata, faz comida e prejudica a barriga. A gente não pode correr atrás, pegar na marra. Se for pra matar, chega com porrete e mata. Já caiu aí. Não faz ele gritar. Aquele serve pra comer. Já leva lá na água quente. Tira pena. Aí pode fazer comida pra valer. Aquele é saúde, tudo de boa. E não pode correr atrás.

Para bovinos também se aplica o mesmo pensamento: "você vai matar uma vaca tem que ligar o pensamento lá e a Deus também". Narrou uma estória em que esses princípios não foram respeitados e ele passou mal. Ele gostava de comer bucho, então, decidiu ir ao frigorífico:

Quando cheguei lá vi um touro dando porrada. Ele tava saindo lágrima assim. Pedindo socorro. Eu falei e agora? O cara falou: daqui a pouco a gente vai matar o boi e você leva a bucharada. O cara matou o boi, carnearam lá. Eu pensei naquele boi que tava chorando alí. Aí a dona fez a comida. Eu fiquei pensando. Vou comer. Peguei mandioca, arroz de carreteiro, fui comendo. Mas a noite me deu aquele estufação. Agora eu lembrei daquele boi. Tá me fazendo mal. Porque o boi percebeu que ia morrer, tava saindo lágrima. Olhou assim, balançou a cabeça. Ele tava sofrendo da morte. Tava chorando. E o cara tava todo mundo alegre. Vamo matar esse boi.

A visão dele sobre os animais e de como extrair o alimento carregam consigo uma ética do não-sofrimento ou do mínimo do sofrimento possível ${ }^{103}$. O animal serve de alimento, mas não é todo animal. Ao animal que se pode matar para comer deve-se imprimir o mínimo

\footnotetext{
${ }^{103} \mathrm{O}$ pensamento/sentimento do rezador lembra o pensamento de uma corrente de ética ambiental nãoantropocêntrica conhecida como patocentrismo, ética do bem-estar animal ou extensionismo em que se atribui um valor intrínseco aos seres sencientes. O precursor desta linha de pensamento foi Jeremy Bentham, que dentro da escola do utilitarismo, desenvolveu uma filosofia moral que veio a influenciar a tese dos direitos dos animais. É bem conhecida sua frase, que diz: "não importa se os animais são incapazes ou não de pensar. O que importa é que são capazes de sofrer". Seus principais teóricos são Peter Singer e Tom Regan (1983), este escreveu sobre os direitos e a libertação dos animais. O fundamento do patocentrismo é evitar o sofrimento dos seres sencientes. Segundo Stöhr (2002, p. 325): "o patocentrismo surgiu no início da tradição utilitarista. O ponto de partida normativo do patocentrismo não é "eles são capazes de raciocinar?", mas "eles têm capacidade de sofrer?"”
} 
de dor possível. Porque se o animal sofrer, o ser humano pode passar mal, como ele mesmo já passou por essa experiência.

Sobre a braquiária, o rezador, tem o seguinte pensamento: "aqui tá cheio de braquiária se a gente queima transforma em doença do humano. Dá coceira. Transforma a doença no humano e no animal também. Primeira coisa vai, no animal, depois transmite no humano". A rezadora complementou: "cobra também cria". Mas para ele, existem alternativas: "a cinza da braquiária serviria para fertilizar o solo. É o calcário caseiro. Mistura bem misturadinho. A gente pode fazer. Daqui dois, três anos ajeitar a coisa". Mas acabar mesmo a braquiária é difícil: "depois que tá formado mesmo não acaba. Eu trabalhei dois anos na roça pra acabar a braquiária, mas não teve jeito: passemo veneno, passemo enxada, sempre continua".

Para a rezadora é por conta da semente. Não existe reza para acabar a braquiária. Segundo o rezador: "a braquiária tem umidade forte. Agora água acaba. Se fizer uma valeta pra braquiária acaba. Apodrece a raiz. O colonião também acaba assim. Com um mês mata". Para fazer roça com braquiária, ele sugeriu:

Agora pra acabar de verdade eu sei uma posição. Por exemplo, pode trazer uma máquina de esteira pra poder raspar de verdade, pra afundar. Aí pode jogar milho e depois que o milho tá formado pode meter a máquina por cima pra misturar tudo. Aí já começa a plantar. Dá um adubo. Um adubo diferente. Aí pode plantar arroz, feijão. Mas tem que cuidar a braquiária. Tem que cortar a braquiária. Aí dois, três anos acaba. Agora o globo não acaba. Nem veneno acaba. Mata só por cima e depois brota de novo.

A rezadora disse que consegue as plantas para fazer os remédios em Sucurui'y. Se chegar uma pessoa que precise do remédio, o rezador afirmou: "chama o espírito. O espírito já fala. Essa remédio é que vai servir. Nós faz o remédio e entrega. Pra poder acontecer o resultado. É assim que funciona. Cada remédio tem o jeito de curar".

Para o rezador: "quem trabalha com o espiritual, os animais e plantas falam. Os humanos não sabem. Quem é espiritual sabe o que sentem. A comida fala. A planta, quando faz uma roça, um plantio, se ela amarelou no sol, está pedindo socorro pra ajeitar". A rezadora confirmou: "tudo fala: esse mato fala, essa lenha fala".

O rezador circulou em diversos mundos, lugares e foi somando conhecimentos. sagrado se apresentou para ele através de diversas experiências, sensações e visões. Seu mestre foi fundamental para o início do seu aprendizado, mas também sua companheira, que como disse sobre ela: "eu sou aluno".

O rezador, de voz tranquila, se expressou de várias formas: pelas narrativas (da sua vida e dos seus aprendizados para se tornar rezador); por sua interpretação da visão de mundo kaiowá-guarani; por sua relação com o invisível; por suas impressões sobre as condições da terra e de Sucuruíy; pelos desenhos no chão (da criação do mundo); pelo canto; pela dança e por mostrar seus objetos, como arco e flechas. A rezadora, de jeitinho meigo, sempre quietinha ouvindo as histórias do seu companheiro, complementava uma 
coisa ou outra que ele dizia. Foram muito generosos em me receber e em compartilhar seus saberes.

\subsection{O DONO DA MATA}

Em um dos dias de campo, fiz uma visita a mata de 40 ha situada na terra indígena com a companhia do rezador 1; do professor e do seu filho; da liderança; da filha da professora 3 e do tradutor. Começamos de manhã e fomos até a tarde percorrendo uma vasta extensão deste espaço. Foram muitas as histórias contadas de forma espontânea. O momento foi de grande aprendizagem e satisfação. Presenciei o Ñembo'e (reza) para os Jara antes de adentrarmos na mata; a reverência e o respeito aos seres; o conhecimento e o senso de localização na mata; o cuidado e o saber ao extrair raspas de árvores para utilização de remédios; a identificação de plantas e de suas propriedades para a saúde e a alegria de compartilhar um tempo e um espaço onde eles se sentem livres e felizes.

A frente do grupo foi o rezador abrindo o caminho ao fazer a oração e tocar o mimbý. Segundo o professor: "pra entrar no mato, toca o mimbý, aí os bichos sabem que o dono que chamou ele, aí vai embora tudo. Aí pode entra pra caçar e não vai acontecer nada. $O$ bichinho mal vai correr. Quando chove, também toca o mimbý, quando tem o vento forte". Ele falou que tem dois mimbý: um deles foi o pai que deu. Há duas madeiras para fazê-lo: de chiru (que em português é o alecrim) e de guavira (a raiz). O mimbý que ele tem nas mãos é de raiz de guavira, como mostra a fotografia abaixo. Mas o de chiru não é qualquer um que faz, pois, tem que saber a reza.

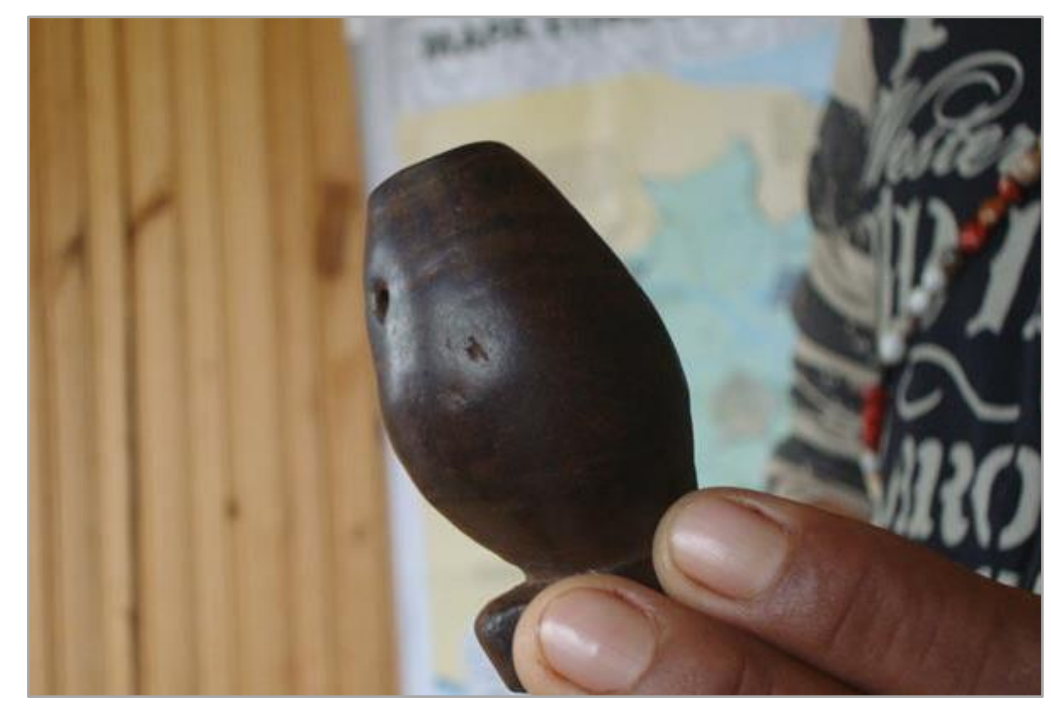

Fotografia 29 - Mimbý.

Fonte: Autoria própria. 
Existem várias árvores de chiru na mata. As árvores mais jovens possuem casca mais fina e folhas verde claras. As mais antigas tem casca grossa, para estas, se souber a reza, é possível extrair um pouco através da raspa superficial do seu caule, conforme a posição da luz do sol. Neste caso, é recomendável que ao final se deixe um pagamento ou oferenda para o chiru. Conforme demonstra o rezador: "tem que conversar com ele pra levar a casca dele. Tirar a roupa, deixar pra pagar". Quando o rezador precisa da raspa do chiru para fazer algum remédio, tira a casca do chiru mais velho que é mais forte. Pelo fato do chiru ser sagrado, existe a reza específica, por isso, não é qualquer um que pode pegá-lo.

O chiru, instrumento de reza, não pode ser colocado em qualquer lugar, de preferência deve ser colocado na casa de reza. Fica de pai para filho, desde que este saiba rezar. Conforme o rezador 2 , o chiru segura a terra através da reza. O rezador humano da terra faz contato com o chiru do céu. Cada lugar tem um chiru. A reza é como muro que segura a terra.

Para mim, começou uma grande aula ao ar livre, onde a cada passo todos indicavam pés de árvores e de plantas por seu nome ${ }^{104}$, a maioria em guarani, e as inúmeras propriedades das mesmas. A experiência foi seguida de estórias e comprovações de casos que povoam os seus imaginários.

O professor mostrou um rastro de onça próximo ao córrego. Para ele, como foi tocado o mimbý, a onça foi embora. Segundo ele, a água do córrego é limpa, dá para beber. O córrego cachoeira passa na divisa da terra indígena e sua nascente fica em Vista Alegre. $\mathrm{Na}$ retomada da terra, eles vinham tomar água lá e lavar roupa. Esse lugar se chama Itarerê: "as crianças pegam a varinha e vem pescar aqui. Pegam a bicicleta e vêm". No córrego tem lambari e bagre. A liderança afirmou que quando chegou a Sucurui'y pegou febre amarela, mas tomou a água do córrego e sarou.

Todo o tempo me mostraram com entusiasmo as plantas e, ao trocarem informações entre si, foram ensinando para mim e para as crianças. Estas se divertiram. E os adultos pareciam crianças nesse espaço. Houve um grande encantamento deles na mata: ingá, limãozinho, canafístula, peroba, jatobá... foram caminhando, conversando e mostrando. Com os sons da mata, os odores e as visões, foram despertando vários sentidos. Mostraram o que é bom para fazer flecha e cocar; a folha que o Ñanderu mistura com o fumo e a coloca no cachimbo; o buraco de tatu; quati; rastro de onça; bugio...

\footnotetext{
104 "As populações tradicionais não só convivem com a biodiversidade, mas nomeiam e classificam as espécies vivas segundo suas próprias categorias e nomes". "(...) essa diversidade da vida não é vista como "recurso natural", mas sim como um conjunto de seres vivos que tem um valor de uso e um valor simbólico, integrado numa complexa cosmologia". Neste sentido, Diegues (2000, p. 31) propõe o termo etnobiodiversidade, ou seja, "a riqueza da natureza da qual participam os humanos, nomeando-a, classificando-a, domesticando-a, mas de nenhuma maneira nomeando-a selvagem e intocada".
} 


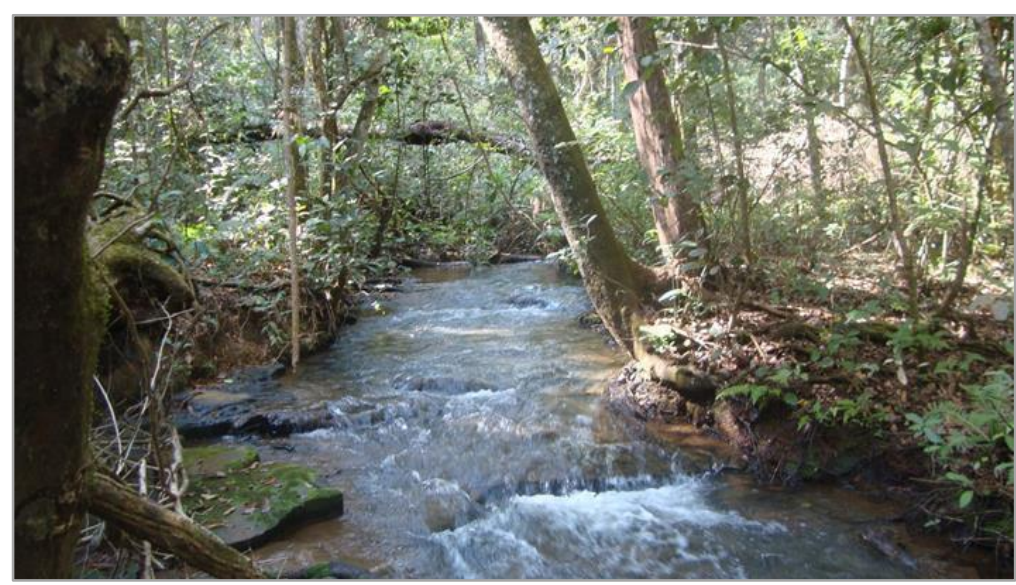

Fotografia 30 - Rio Sucuri ou Córrego Cachoeira. Fonte: Autoria própria.

Atravessamos o córrego, no qual tive dificuldade para atravessá-lo, mas o rezador, com mais de setenta anos o atravessou tranquilamente e, sem ajuda, o que mostrou sua resistência e autonomia. Ele disse que de uma mesma planta são retiradas várias partes para fazer remédios diferentes e uma mesma planta possue diversos jeitos de ser usada.

O rezador conhece muito da mata, como ele disse: "antes mesmo eu já conhece isso tudo aqui. Eu nascido por aqui mesmo. Então, sabe tudo. Fazendeiro tem que tirar chapéu, eu falo assim". Ele falou para a comunidade: "eu fala não pode mexer. Deixar herança todo ano aqui. Nós mesmo não pode mexer. Que é difícil achar peroba agora. O pau acabou, o mato acabou. Então, vamo deixar reservado". Mostrou uma peroba que para ficar grande demorou muito tempo, por isso: "tem que respeitar. Se não respeitar quer vender, então tem que ter a fiscalização pra não mexer. O que é reservado, já foi reservado". Seguiu a caminhada e mostrou o lugar onde o bugio sempre canta, perto de uma peroba bem grande: "bugio gosta de peroba".

Perguntei se já houve algum caso de derrubada de árvore para vender. A liderança disse que não. E, completou: "a gente não vai fazer, não vai deixar. Tem que preservar". O professor falou que a comunidade leva madeira de árvore que já caiu para fazer e reparar as casas. Ele esclareceu que a maioria das famílias utiliza fogão a gás. Seu pai, o rezador, confirmou: "meu filho usa mais gás. Eu não sabe acender o gás. Eu uso fogão de lenha". Perguntei se pode pegar qualquer pau para fazer lenha das árvores que caíram. Ele disse: "pode. Porque já perdeu. Aproveitar o podre. O fica seco, a lenha". E se for um chiru que caiu? Ele respondeu firme:

ah, não. $O$ chiru não pode. Se queimar, dá doença. $O$ chiru não pode nem mexer, tem que deixar alí mesmo. Nunca não fica podre não, ele aguenta. $A$ casca fica podre, mas o cerno não fica podre. Igual aroeira, só a casca, por dentro não, pode jogar na água. Atura mais que nós.

Três gerações da família que pertence tradicionalmente a Sucurui'y foram interagindo nesta caminhada: pai, filho e neto. O rezador falou da importância de conhecer os remédios: 
"eu fala em Aty Guasu que véio que sabe tudo remédio não vai durar, então tem que ficar o neto, caprichar, saber todo remédio quando crescer, o avô dele morrer. Igual minha esposa morreu, eu ficar sozinho". Disse que a esposa sabia dos remédios de mulher e ele sabe mais remédio de homem.

Paramos no lugar onde o rezador iria extrair a raspa da casca de uma árvore para fazer remédio para um menino pequeno. Vimos uma árvore em que alguém havia extraído a raspa da casca no lugar errado. Ele disse: "tem que tirar onde o sol nasce". Seu filho complementou: "remédio tem que saber tirar. Depois de dois ou três meses vai sarar". Havia uma retirada forte como se tivesse sido com um machado. O rezador falou: "se tirar tudo fica podre. Não pode extrair muito. Só pouco. Preservar". Ele retirou um pouco de uma árvore e disse que iria tirar de outra porque daquela já havia tirado bastante: "raspar do lado certo, para formar de novo, tudo a casca. Então, remédio não pode deixar tirar tudo".

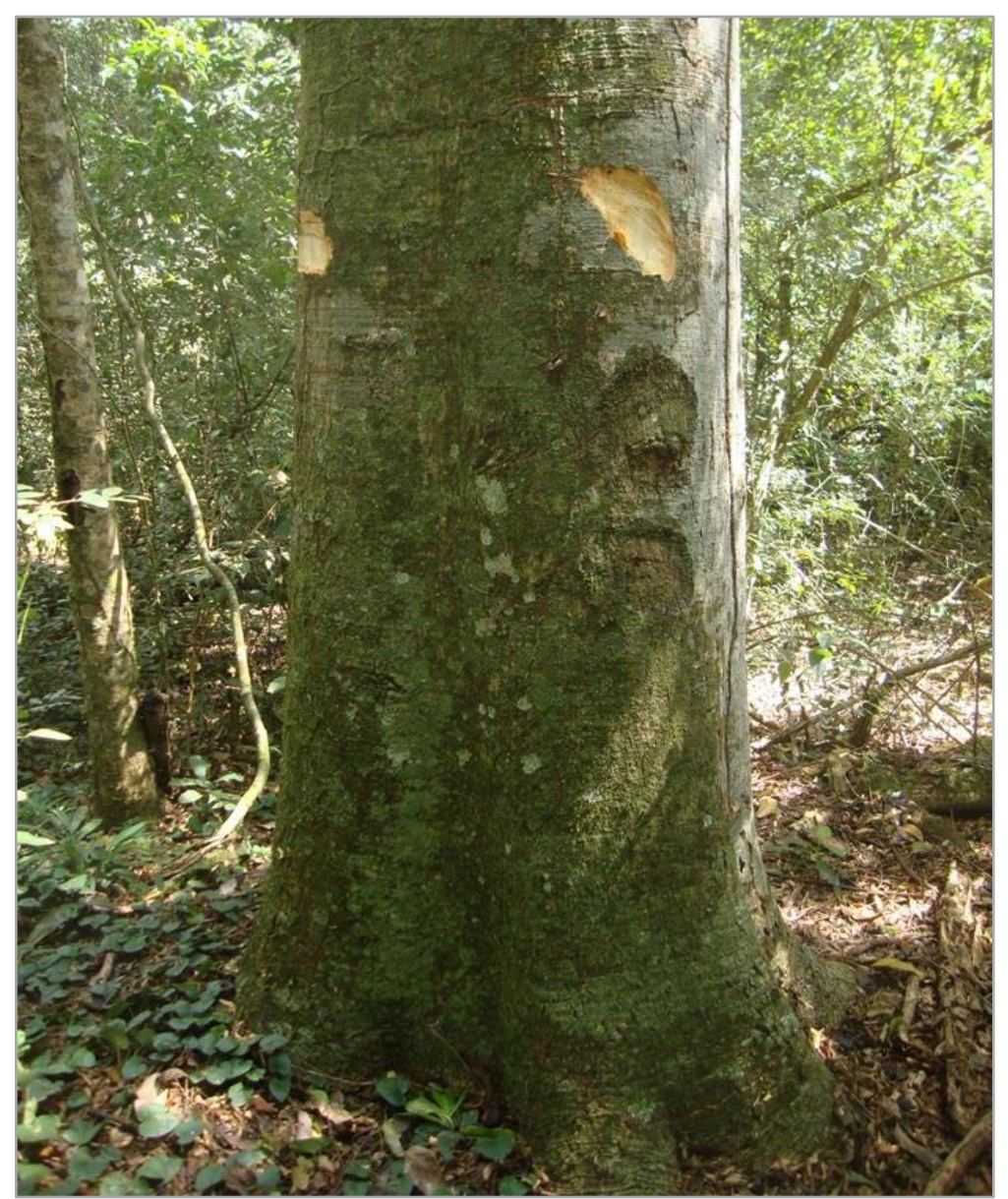

Fotografia 31 - Retirada da casca do chiru. Fonte: Autoria própria.

Nesta observação percebi que o rezador possui um conhecimento profundo sobre a mata e sabe onde estão as árvore e plantas, seus usos e o ritual para extrair delas o que necessita para fazer um remédio. Seu procedimento passou: pela identificação da árvore; 
escolha de qual seria a mais adequada conforme seu tamanho, localização e grau de extração; autorização através da reza para extrair a quantidade necessária para fazer o remédio, raspando a sua casca do lado e do modo certo. Foram feitas extrações de raspas de duas árvores, sendo que uma delas era o chiru, neste caso além das etapas acima descritas, ele "pagou" o chiru, oferecendo-Ihe um pedaço de tecido da sua camisa, que foi colocado no local onde retirou a sua raspa.

A liderança mostrou árvores de chiru e falou com reverência: "a gente respeita muito, que é sagrado. Se você vai descascando de qualquer jeito, pode acontecer alguma coisa no seu caminho. Pode quebrar o braço. Cair num toco de pau e se machucar. Porque ela tá aí e não tá perturbando ninguém". Havia chirus situados junto a outras árvores grandes, como peroba. Na parte mais central da mata estão as árvores nativas e maiores.

O professor também raspou um pouco da casca do chiru: "o remédio, como meu pai fala, tem que levar pouquinho. E depois tem que deixar algum pedaço, roupa. Algum. Porque você tá pagando pra ele. Pra não acontecer. Porque você tá tirando a casca dele". Afirmou que também fez a reza: "eu pedi. Então, na verdade pra tirar o casco. Não pode chegar, meter e levar. A gente kaiowá sabe que qualquer coisa acontece. Qualquer coisa eu vai pisando num buraco, vai quebrando, aí eu vou cair, vai acontecendo algumas coisa. Pra não acontecer, né".

Há como se fosse uma categorização das árvores de chirus, em que as árvores mais velhas e intactas são mais respeitadas. Para o professor: "cada chiru tem um poder". Ele mostrou uma e disse: "esse é mais respeitado porque ninguém tirou a casca".

O professor falou da época em que Sucurui'y era fazenda: "há muito tempo se tirava madeira grossa, forte pra fazer curral. Hoje em dia nós mesmo fala: tem que preservar. Nós temos regimento na aldeia. Se a gente quer, vem pegar lenha porque já tá apodrecido". E seguiu dizendo que: "antes tinha mais mato. Depois da retomada tinha menos".

Fomos até o centro da mata que fica perto da divisa (uns 500 metros). Segundo a liderança: "a mata fica bem na beirada. Quando nós demarquemos, nos pegamos uns 20 ha deles na divisa. E ficaram uns $15 / 10$ ha de mata pra eles, pra fazenda deles. Eles são arrendatários. Mas mexem mais com plantio de soja”. No entorno da terra indígena prevalece mais o plantio de milho e soja.

Chegamos até certo ponto da mata, mas de lá retornamos, pois, segundo o rezador: "desse ponto não vamos porque tem sucuri. Se o cachorro for aí não volta mais. Sucuri gosta de água. Sucuri come cachorro e come gente também. Não tem reza pra Sucuri. Tem pra peixe. Sucuri não tem jeito". Não teve ninguém de Sucurui'y que tenha sido mordido, mas teve gente que já matou sucuri. Segundo ele, a banha de sucuri é boa pra passar na coluna e tem gente que a come. 
No retorno, a liderança narrou uma situação em que passou de fato a acreditar na palavra do bisavô, numa experiência em que sentiu na pele a realidade do mito:

\begin{abstract}
Meu bisavô falava assim pra mim. Eu saia na mata com o machado e saia batendo com o machado nas árvores. Ele dizia não faz isso não que sua pele vai ficar tudo cicatriz. E eu não acreditava. E não é que com um tempo eu quebrei o braço, jogando bola, e fiquei com cicatriz grande. Aprendi para não tirar casca de árvore à toa. Aí agora eu ensina pros guri. Porque a madeira tem dono. Quando eu tinha quinze anos comecei a descobrir que é verdade mesmo. Se o cara não acreditar, depois que ele vê umas coisas, vai acreditar.
\end{abstract}

E seguiu muito falante, contando suas experiências na mata: "eu já andei nessa mata de ponta a ponta. Eu já vi bugio, onça na mata. Eu vi uma onça pintada, cheguei perto e voltei logo na divisa. A cachorrada não queria deixar eu passar". Ele está acostumado a entrar sozinho na mata porque assim não faz barulho: "no lugar que vou não faço barulho, você percebe, você tá vendo uma coisa na sua frente, uma cobra, um bicho assim mais grande". E, também para perceber melhor os animais: "você caminha e para. Aí o bicho fica no jeito pra ir lá na pessoa. Mas os bicho do mato é mais difícil pegar um índio porque o índio e o bicho é quase a mesma, né. Porque anda no mato, né. O índio sabe o lugar que tem bicho. E o índio sabe o lugar que tem cobra. E o cara não pode cruzar alí, né". Mas apesar de andar muito pela mata, uma vez se perdeu. Por isso, é necessário observar as marcações da mata e de como se localizar nela: onde o sol nasce, onde está o banhado e a picada... Sua estratégia foi fazer a reza de quando se está perdido para se achar e não se apavorar.

De regresso, paramos na margem do córrego para comer, onde compartilhamos os alimentos que havia levado. A liderança aproveitou para conversar sobre os problemas e as melhorias que gostaria de implementar. No quesito uso do fogo e queimada disse que: "queima aqui na mata nunca teve. Mas o pessoal queima na região onde não tem mato, tem capim braquiária. Mas a gente já fez reunião pra não acontecer mais. Porque o fogo termina a natureza. Se invadir aqui termina tudo. Não tem como controlar". O professor disse: "na aldeia era lugar de lavoura, vamos dizer assim. Por isso que a terra é assim". Então, perguntei sobre a braquiária e como vencê-la, ao que respondeu:

Num vence assim. Pra vencer mesmo tem que plantar as árvores nativas, seja qualquer árvore - calípio, árvore nativa, árvore frutífera. Porque aí ele cai a talha. Ele fica acabando. Se você não faz isso, não acaba. Meu pai tem prova. Ele plantava no mandiocal. Ano, ano. Desde que ele plantou até hoje. Não acaba assim. Ele carpe. Quando acaba o mandiocal nasce a braquiária. Quando acaba a mandioca, ele vem. Só debaixo da árvore. A árvore cresce, a folha cai. Aí ele morre.

Para a liderança, durante o período em que os fazendeiros estavam em Sucuruíy, houve muito desmatamento e reconheceu: no "tempo que a gente ficou de fora, derrubaram esse mato. Aí deixaram nesse pedaço aqui. Deixaram só na beira desse riozinho. Mas 
devagar a gente vamo chegando". Ele tem curiosidade sobre projetos de reflorestamento e revelou:

\begin{abstract}
a minha ideia antes era plantar eucalipto. Pelo menos uns 1.700 pé. Só que fui procurando. E me disseram: é bom pra cá. Calípio dá dinheiro. E depois pra tirar o pé do calípio que ficou, tem que pegar de novo? Aí eu desisti. Aí eu vi o projeto da erval. Era um projeto, se eu não me engano, do governo federal parece. Aí eu peguei essa muda. Inclusive eu plantei 2.500 pé de muda de erva-mate. Só que não pegou bem porque não tinha equipamento pra molhar as mudas. Eles traziam a muda pra mim e deixava. Só que não tinha pra mim molhar as mudas. Aí as mudas morreu tudo. Só os pé que tava pertinho de casa que eu molhava todo dia, aí pegou. Erva mate pra fazer tererê. Aí depois a Funai trouxe pra mim, se eu não me engano 120 muda. Aí eu plantei dentro do mato. E agora tá dando conta.
\end{abstract}

Desta experiência, tirou as seguintes conclusões sobre a época em que se deve plantar a muda de erva mate e sobre o seu cuidado:

em setembro que não precisa molhar muito que tem chuva. Mas se for em agosto, tem que aguar duas vezes por dia. No lugar que a gente tá morando agora, só tem braquiária, que já era uma lavoura, então, precisa de tratamento, né. Se tiver projeto de reflorestamento, vê se planta umas muda no meio das braquiária. Talvez a muda vai se desenvolver, talvez não. Porque a terra tá muito fraca. Precisa preservar mais, né. Os projeto de reflorestamento entra na preservação também, né?

A liderança citou seu exemplo, na relação com os tatus pretos que vivem perto da sua casa: "toda vez que eu vou pra escola a muiê fala assim: e esses tatu preto, aí? Não, esses aí eu vou criar". A ideia de projetos também o atrai, pois, sua intenção é: "vê se a gente consegue trazer uns projeto, uns curso pra cá". E, também de preservação: "aqui já tá ficando preservado, já é preservado. Agora a gente tá preservando mais. Viu como é que é a riqueza que a gente mostrou alí: tem onça, anta. Tem vários bichos, alí”. $\mathrm{E}$, com isso, pretende trabalhar para preservar mais:

a gente pesca mais do que caçar. A maioria vive aqui no mato. Na parte de preservar pra não queimar. É pra não destruir muito o que já é da natureza. Graças a Deus que não aconteceu nada com esse mato daqui. Tem aldeia assim que é muito explorado, né. Tem aldeia que pegam uma área preservada e começa a explorar a natureza, né. Pega árvore, corta, vende. Afora aqui não. Você viu como é eu é. Mas a gente tá preservando. Sabe que é difícil, né. Aqui na aldeia Sucurui'y a gente é mais assim da preservação. 


\section{TERRA JATAYVARY}

\subsection{O LUGAR DE JATOBÁ}

A terra é conhecida por diversas denominações. Além de Jatayvary (o lugar de jatobá), também é chamada de Rancho Kuña, uma das áreas de ocupação tradicional, ou Lima Campo, sobrenome de um dos primeiros fazendeiros da região.

Inicialmente, a área foi titularizada em 21/12/1898 pelo então estado de Mato Grosso como sendo de propriedade do Tenente Coronel João Lima, "que no final do século XIX detinha em seu poder 95.434 ha, seus descendentes foram pioneiros na ocupação dessas terras que, por isso mesmo, os índios viriam a denominar 'Lima Campo'”, relata Thomaz de Almeida (2005, p. 26) no Relatório circunstanciado de identificação e delimitação da Terra Indígena Jatayvary e, prossegue:

Trata-se, com efeito, de região que comporta campos naturais e que foi
controlada pela "família Lima", a partir de 1898, se considerada a análise da
cadeia dominial. Além disso, é um termo ou denominação historicamente
determinado, uma toponímia específica, condicionada à existência de
relações entre dois grupos humanos sobre um mesmo espaço territorial que
se processa no tempo pelo menos a partir do final do século XIX quando "os
Lima" ocuparam aquela parte do território Kaiowa. (...) Pela descrição dos
índios, os Lima surgem na região como produtores de erva-mate
associados ou a serviço da Cia. Matte Laranjeira - ao cotejar, com efeito, o
território arrendado por esta empresa extrativista que englobaria as terras
tituladas por João Lima, é de se supor a existência de negócios entre este e
Tomáz Laranjeira. Os descendentes de João Lima mantiveram o controle da
região depois de sua morte e do declínio da Cia. Matte Laranjeira, dividindo
em porções as 95.434 ha tituladas (Idem).

Enquanto o patriarca era vivo, os índios permaneceram por lá nos fundos da fazenda e realizavam trabalhos esporádicos. Já com os seus herdeiros, a situação se modificou e a tolerância aos índios da região piorou. Vários foram levados para áreas de reserva, principalmente, a de Dourados, mas também para outras terras indígenas, como Caarapó, Rancho Jacaré, Guaimbé e Pirakua. Outros, se mantiveram em fazendas das redondezas e grupos menores permaneceram no local. Os herdeiros foram vendendo e loteando a terra, fracionando-a e ampliando o rastro de desmatamento de uma área onde, originalmente, existiam densas florestas, campos naturais e ervais nativos.

Segundo o relator Thomaz de Almeida (2005, p. 27), Lima Campo é um "tekoha guasu, isto é, um espaço territorial ocupado por diversos tekoha relacionados entre si." Segundo os depoimentos de idosos e conhecedores da região: "até os anos 1950/60, pelo menos cinco tekoha estavam bem configurados na região: Manga'isyty, Yramõi (Rio São João) e Rancho Kuña. Os de Kuati Huguái e Camba Jety que não foram localizados” (Idem). Suas áreas naturais, pertencentes à bacia do Rio Dourados, abrangem: "o Ribeirão 
Douradilho, Córrego Lagoa Corona, o Rio Yramõi (São João), Córrego Fortaleza, Córrego Envernadinha, Córrego Jatayvary (Tronqueira), Córrego Paranerikue (Estiva), Córrego Teviy (Passarinho) e a Lagoa São Francisco" (Idem).

No movimento que propiciou a realização do relatório de identificação e delimitação da terra estiveram presentes três famílias extensas cuja história está relacionada à ocupação tradicional da área. Um episódio ocorrido em 1993, o assassinato de um kaiowá pertencente a uma destas famílias, instigou a organização do grupo para cobrar a demarcação da terra. Até então, eram trinta e sete pessoas, que segundo Moreira da Silva (2002, p. 95), "foram violentamente expulsos da área e refugiaram-se numa pequena mata na região de Lagunita, próximo a Lima Campo, local em que ficaram encurralados, sofrendo pressões e ameaças de morte pelos fazendeiros".

Os trinta e sete indígena foram removidos através do órgão indigenista para a Reserva Indígena de Dourados, em outubro de 1993, que já era superpovoada à época, porque dentre outros fatores, funcionava como um depósito de índios "desaldeados". Chegando lá, enfrentaram muitas dificuldades e perseguições de índios terenas: "ameaçados pelo capitão Ramão Machado e sua milícia particular, chamada de polícia indígena, os remanescentes de Lima Campo em Dourados, em reunião, tomaram a decisão de retomar a área Lima Campo" (Idem, p. 97).

Várias comunicações foram feitas pela comunidade à FUNAI para que esta providenciasse a constituição de um grupo técnico para realização de estudos de identificação e delimitação. Quando em 15/06/1998 a comunidade decidiu sair da reserva de Dourados e retornar para Lima Campo, onde "acamparam em precárias condições às margens do rio Dourados próximo à Rodovia Federal BR-463", eram duzentos e cinquenta, sendo noventa crianças (MOREIRA DA SILVA, 2002, p. 99-100).

No mesmo ano de 1998, a comunidade tomou conhecimento que um proprietário havia contraído um empréstimo rural no Banco do Brasil e não tinha quitado a dívida. A terra iria a leilão, quando os índios de Jatayvary, através de medida do MPF conseguiram permanecer neste local que abrange cerca de 181,43 ha. 


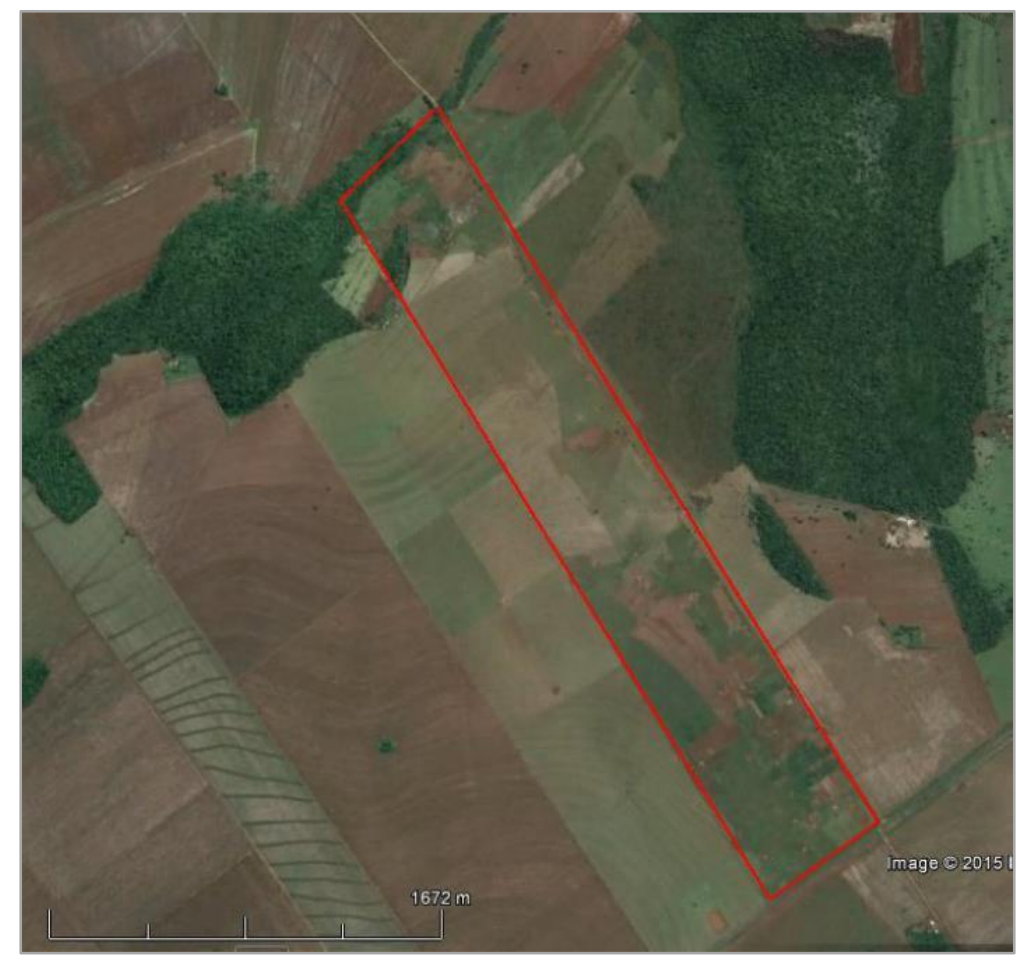

Fotografia 32 - Área de 181,43 ha em Jatayvary.

Fonte: IMAD, 2015, p. 39.

Esta é a área em que estão até hoje, como mostra a fotografia acima, juntamente com pequenos trechos de terra, situados à margem direita da estrada de terra que corta a área indígena, esperando o deslinde das ações judiciais. Lá podem ser vistos vestígios de construções do antigo proprietário. Enquanto isso, o restante das suas terras tradicionais, está sendo ocupada por fazendas que plantam soja, milho, cana-de-açúcar e criação de gado, produzindo a "riqueza" em terra indígena.

O grupo de trabalho para identificação e delimitação foi instituído pela Portaria 199 PRES/FUNAI, em 09/04/1999. O relatório final foi entregue em março de 2005 e publicado DOU n. 170 , de 02/09/2005, delimitando a superfície da terra indígena em 8.800 ha. A atual situação fundiária de Jatayvary é de terra indígena declarada, pela Portaria do Ministério da Justiça n. 499, publicada no DOU no 78, em 26.04.2011. Pode-se dizer que juridicamente, é uma terra indígena reconhecida, mas não regularizada. Houve a demarcação administrativa, mas falta a homologação e pendem sobre ela questionamentos judiciais sem decisão final com trânsito em julgado.

Embora esteja situada no município de Ponta Porã, a terra indígena encontra-se a uma mesma distância (cerca de $60 \mathrm{~km}$ ) entre os centros urbanos de Dourados e Ponta Porã, em um trecho da BR-463. Indo de Dourados para lá, Jatayvary fica localizada na margem direita da BR-463 e seus limites visuais, de acordo com a indicação de tamanho do Relatório, vão até as torres de sinais. Nesse sentido há uma entrada para Jatayvary e para as fazendas através de uma estrada de terra, como demonstra a fotografia seguinte. 


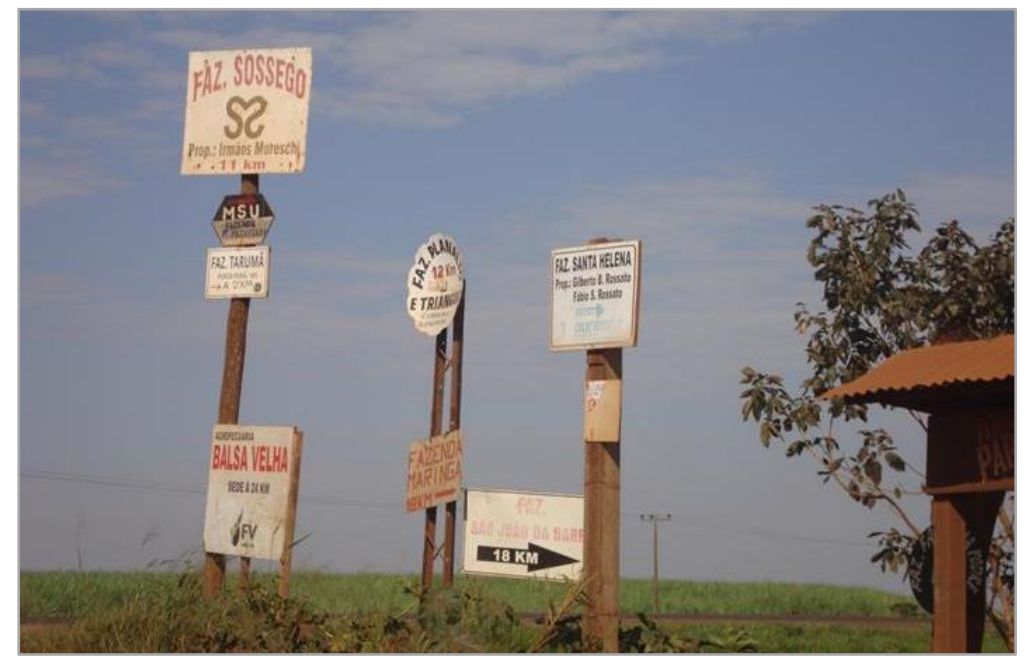

Fotografia 33 - Entrada de Jatayvary. Fonte: Autoria própria.

Ao entrar na estrada de terra (vide a próxima fotografia) percebe-se que o lado direito está desmatado, mas há a presença de uma vegetação de cerrado que está se recuperando. Este pedaço longo de terra (de aproximadamente 916 ha) foi, no passado recente (outubro de 2002), colocado à venda através de um loteamento para colonos pelo extinto Banco da Terra. Na ocasião, era sabido de todos que a terra indígena estava em fase de identificação por grupo técnico de estudos. Contudo, isto não impediu que o Banco da Terra adquirisse de um fazendeiro a área para recortá-la em oitenta e três lotes destinados aos colonos. O MPF interviu no sentido de barrar o projeto, por se tratar de terra indígena. Alguns lotes chegaram a ser comercializados, encontrando-se, até hoje, alguns colonos que plantam suas roças, gerando constantes focos de conflitos, principalmente, com os indígenas que moram neste lado, como se verá no tópico seguinte.

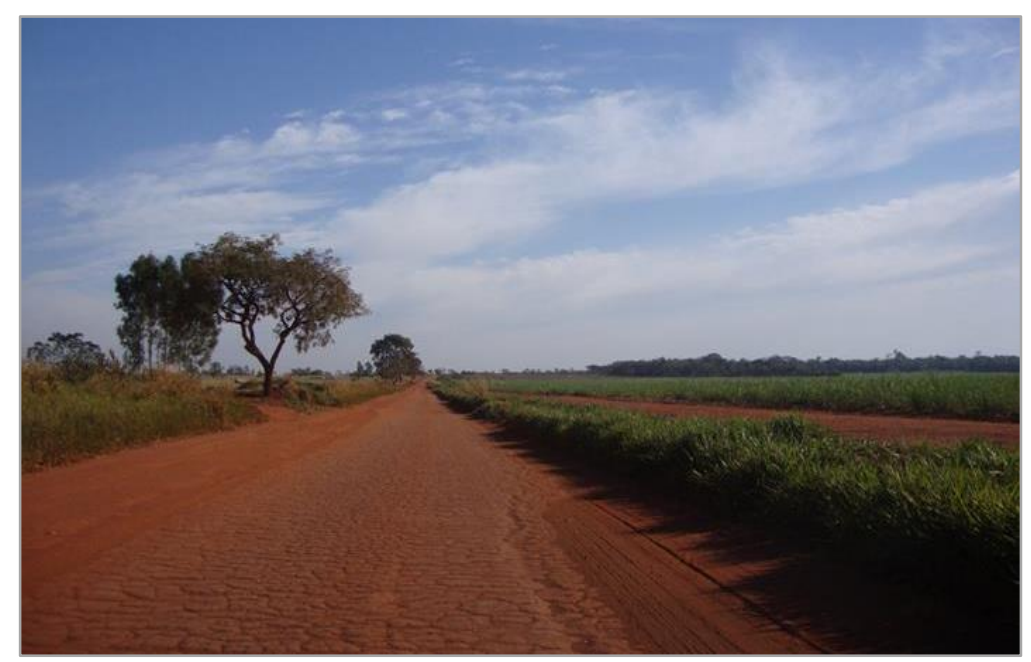

Fotografia 34 - Estrada de terra que corta a terra indígena. Fonte: Autoria própria. 
Nesta terra, foi feito um trabalho de campo prévio entre novembro e dezembro de 2013, quando conversei com o professor, algumas lideranças, e uma moradora da época da ocupação. Fizemos caminhadas às margens do córrego Jatayvary e como era época de guavira, visitamos uma área de guaviral nativo. No campo aprofundado, em agosto de 2014, voltei a conversar com a liderança e seus irmãos; com o professor; com duas famílias que pertencem à área de ocupação tradicional e o enfermeiro da SESAI. Fiz uma visita à escola rural, onde as crianças têm aula; e, também, à matinha situada no lado direito da estrada de terra.

Metodologicamente, adotei uma conversação livre com a indicação de temas relacionados à pesquisa, mas aqui prevaleceu muito a conversa de "denúncia", ou seja, referente aos problemas da comunidade, as reclamações da ausência das instituições, às reivindicações e os encaminhamentos de denúncias de serviços para órgãos ligados a questões indigenistas.

\subsection{A VIDA ENTRE A BRAQUIÁRIA E A CANA}

\subsubsection{Situações atuais}

Atualmente, a maioria das famílias vive do lado esquerdo da estrada de terra, ou seja, na área dos 181,43 ha. Neste lado fica a caixa d'água e um posto de saúde, conforme a próxima fotografia. Existe a presença de algumas igrejas evangélicas ${ }^{105}$. Segundo o enfermeiro, a população é formada por aproximadamente setenta e cinco e oitenta famílias, em torno de trezentas pessoas vivendo em Jatayvary. A maioria das famílias é Kaiowá ou Ñandéva. A divisa é composta por terras com plantios de soja e de cana-de-açúcar e fazendas de gado. Já do lado direito, próximo a colonos que vivem ou plantam no local, moram, de acordo com informações da liderança, cerca de dez famílias, em torno de sessenta pessoas.

O posto de saúde, ou postinho, funciona como uma área de encontro comunitário e de reunião, pois, como fisicamente não há uma escola, as reuniões da comunidade ocorrem neste local. Em conversa com o enfermeiro da Saúde Indígena - SESAI, ligado a Ponta Porã, ele relatou que seu expediente é de segunda a sexta e que realiza alguns trabalhos preventivos, como, palestras com crianças em idade escolar sobre drogas.

\footnotetext{
105 Verifiquei a presença de duas igrejas instaladas: a) Igreja da Missão Kaiowá, que possui duas instalações, uma onde são realizados os cultos no sábado e domingo e outra para realização de trabalhos comunitários; b) Igreja Pentecostal. A igreja Deus é Amor estava se instalando na terra indígena.
} 


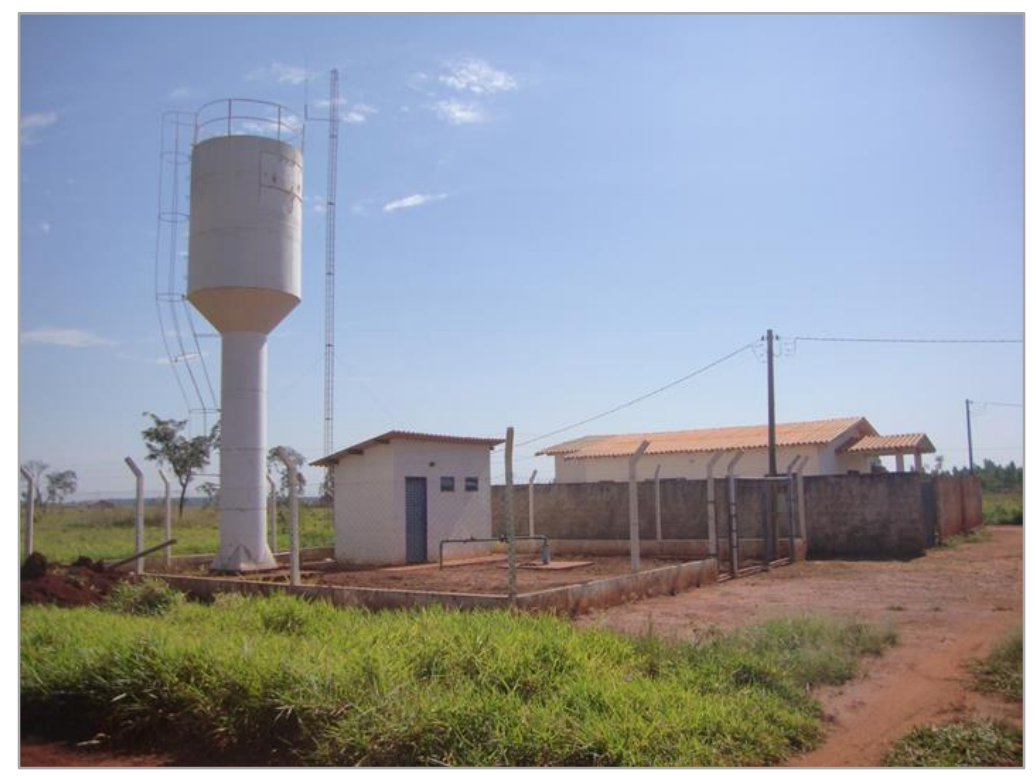

Fotografia 35 - Caixa d’água e posto de saúde. Fonte: Autoria própria.

De acordo com informações do enfermeiro, a estrutura de atendimento à saúde indígena em Jatayvary é composta também por: uma agente de saúde da comunidade; uma enfermeira, que cuida da prevenção da saúde da mulher; médicos; dentista; assistente social e nutricionista. O serviço da Pastoral da Criança vai quinzenalmente à comunidade, levando doações.

Por ocasião do campo realizado em 2014, pude verificar a previsão da realização de obras de "melhoria e ampliação do sistema de abastecimento de água", como indica a fotografia abaixo. Segundo o enfermeiro, o projeto de abastecimento de água visa atender a área dos 181,43 ha legalizados. A maioria das famílias não tem fossa. Quanto ao descarte de lixo, a queima é a estratégia mais utilizada.

Os moradores do lado direito seguem desassistidos de água e energia. Conversei com algumas destas famílias, que apontaram soluções provisórias para amenizar a luta diária em busca da água. Algumas moradias ficam distantes do córrego Jatayvary e vão até lá, a pé ou de bicicleta, com seus vasilhames, muitos deles são embalagens de agrotóxicos descartadas pelas fazendas, conforme o destaque da próxima fotografia. Segundo o Imad (2015, p. 45) o córrego "se encontra contaminado com os defensivos agrícolas provenientes da lavoura de cana ao redor da aldeia". Suas sugestões seriam: fazer poço; utilizar uma carriola formada por cavalo mais carroça para pegar água do córrego ou construir caixas $d^{\prime}$ água ${ }^{106}$.

\footnotetext{
106 Segundo a agente de saúde, a utilização frequente de embalagem de agrotóxico para pegar e armazenar água pela comunidade se dá pela falta de alternativas. Muitos fazendeiros e colonos deixam as embalagens no local de uso.
} 


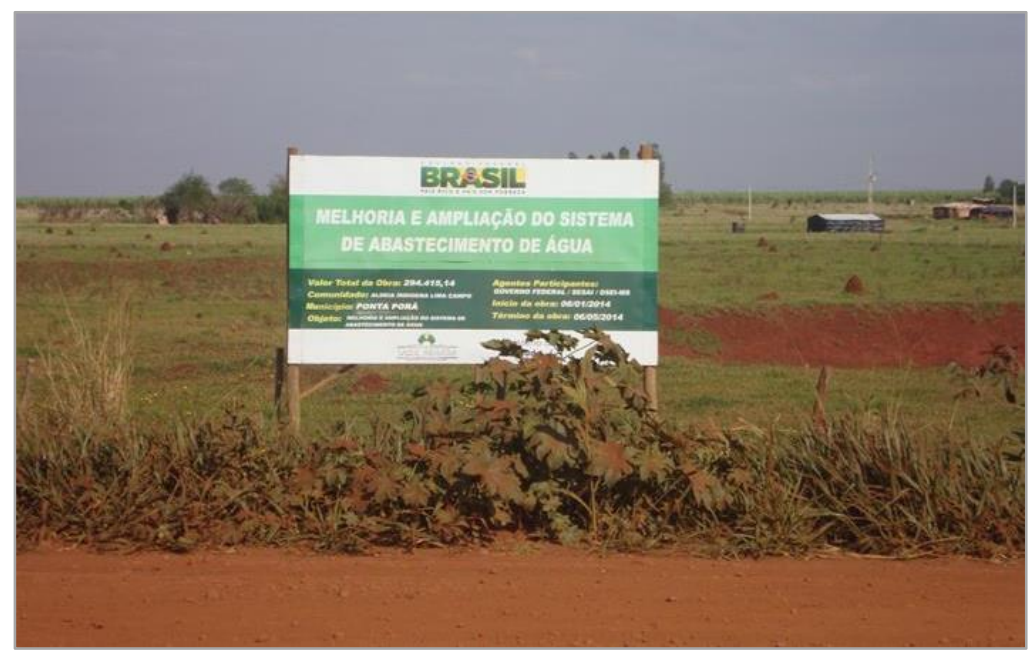

Fotografia 36 - Informação sobre o sistema de abastecimento de água. Fonte: Autoria própria.

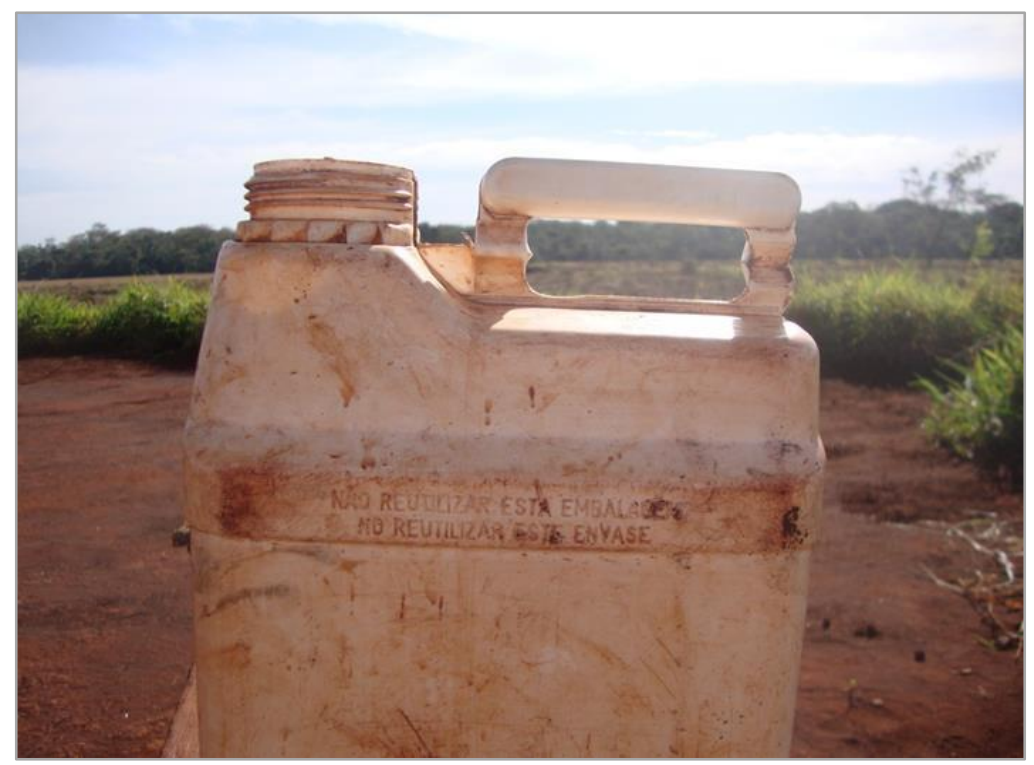

Fotografia 37 - Embalagem de agrotóxico para armazenamento de água. Fonte: Autoria própria.

Em contato com uma moradora que vive próximo ao córrego, fizemos uma caminhada rumo a ele através de trilheiros, cercados de braquiária por todos os lados e, chegamos a alguns pontos que ela indicou: lugares de tomar banho, de lavar roupa e de pegar água para beber. Ela é uma exímia conhecedora das plantas do local, principalmente, das plantas de brejo. O córrego também tem peixe, em que a comunidade pesca de vez em quando e aparecem alguns mamíferos, como paca.

Nesta caminhada, junto ao pouco que resta de mata ciliar, há um local próximo a fazenda de gado ao lado de Jatayvary, que tem uma pontezinha sobre o córrego. A moradora fez questão de mostrar onde ela estava, mas para isso tivemos que atravessar por baixo de uma cerca feita de madeira de aroeira com arame, que fixa os limites da 
fazenda. Lá existiam várias árvores "madeira de lei", como aroeira e jatobá. Neste local, a braquiária estava bem baixinha, pois, os bovinos e os cavalos ficam soltos ruminando o tempo todo.

Nesta parte, a mata ciliar é mais densa. Há uma cerca ao longo do córrego. Ela mostrou o lugar onde um tio seu foi enterrado e disse: "ele mordeu a cobra" perto do córrego e morreu ali ${ }^{107}$. Ela falou várias vezes que quando aquele fazendeiro deixar a terra, ela vai querer ficar naquele pedaço, pois, é muito bonito, por isso, não vai deixar cortar nada e que irá fazer uma piscina no córrego Jatayvary porque tem muito neto. Ela gosta muito de ir tomar banho e pescar naquele trecho do córrego.

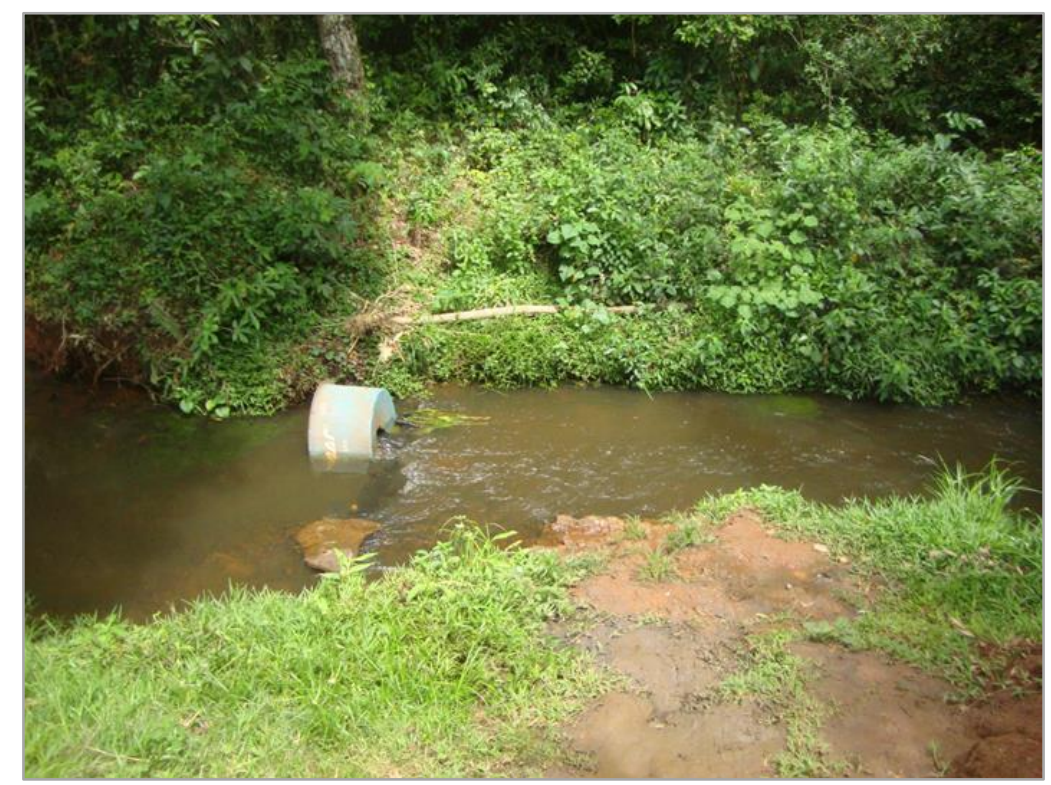

Fotografia 38 - Córrego Jatayvary.

Fonte: Autoria própria.

Ao regressarmos a sua casa, passamos por uma área em que o pai dela havia morado e tinha plantado muitos bambuzais, que estão lá até hoje. No tempo dele se plantava muita rama, milho, arroz e abóbora. Ela lamentou não poder plantar porque a terra está tomada de braquiária e não dá pra limpar com a enxada, por isso, gostaria que fosse passado o trator para poder plantar.

O professor, que é seu vizinho, se juntou a nós no terreiro da casa dela e começamos a conversar. Ele disse que Jatayvary não tem roça porque tem muita braquiária e precisa de trator para limpar a terra. A presença de braquiária gera uma dependência do trator para preparar o solo para o plantio. As dificuldades residem em ter o trator e o combustível disponível na época adequada para aqueles que dispuserem das sementes. O tempo da

${ }^{107}$ Significando que a cobra mordeu ele. O seu português não foi fácil para eu entender, na ocasião, estava sem tradutor. 
chegada do combustível e das sementes nem sempre coincide. Então, é frequente perder o calendário de plantio.

Em terras não regularizadas as dificuldades são ampliadas, pois, a depender da política local e regional, muitos serviços não são oferecidos pelo argumento de ser área de litígio. É o que se pode perceber na comparação feita pelo professor entre a gestão municipal passada de Ponta Porã e a atual. Segundo o professor, o prefeito atual: "não dá o trator porque é invasão" e que "nem lá (referindo-se a Jatayvary), nem em Kokue'i (outra terra indígena em "litígio") pode mexer". Na opinião do professor, este prefeito está sendo ruim para a comunidade, pois, cortou alguns benefícios como a lona e o trator. Na gestão do outro prefeito, ele mandava o trator todo ano.

Por conta da relação com os fazendeiros da área, os moradores de Jatayvary não trabalham nas plantações de cana-de-açúcar da redondeza. Mas às vezes os fazendeiros tentam arregimentar trabalhadores para poucos dias. Neste caso, eles só vão se forem em grupo de aproximadamente cinco pessoas para evitar confusão. A maioria dos índios que trabalham na cana vem da reserva de Dourados. O pessoal de Jatayvary trabalha mais no eucalipto, em empresas próximas chamadas COAMO e Pindorama. Mas a situação é bem difícil para quem não tem trabalho. Em área de litígio os estigmas e as dificuldades para conseguir trabalho são ampliados. Conforme o professor, a cesta básica da Funai vem certa uma vez por mês, mas a cesta do estado atrasa e chega a cada dois ou três meses.

Em 2013, a Funai foi colocar os marcos demarcatórios na terra indígena, o que conseguiu fazer do lado do ex-loteamento do Banco da Terra mas foi impedida de fazê-lo do lado das fazendas de soja e de cana-de-açúcar. Todavia, conforme o professor, os marcos postos foram retirados recentemente. É frequente os fazendeiros desmatarem os fragmentos remanescentes de mata. No ano de 2013, seguiu contando o professor, os fazendeiros tentaram desmatar, mas os índios fecharam a estrada, em sinal de protesto.

O professor ${ }^{108}$, que tem cerca de trinta anos, é da terra indígena Takuara e, mora há oito anos em Jatayvary com sua esposa e filhas, sendo hoje o único professor do lugar. Ele concluiu o Ará Verá e o Teko Arandu, na área de ciências humanas. É o autor da cartografia étnica de Jatayvary, trabalho realizado por ocasião dos seus estudos, como pode ser vista a seguir. A educação escolar indígena em Jatayvary enfrenta muitas dificuldades. A primeira delas é a inexistência de uma escola dentro da terra indígena. A escola constitui uma reivindicação da comunidade para que se possa evitar as constantes discriminações que os alunos sofrem, bem como o tempo e o risco do deslocamento.

\footnotetext{
${ }^{108}$ Mesmo não sendo original de Jatayvary, se sente responsável pela terra. Ele conhece muita gente da comunidade e suas dificuldades. É bem informado sobre o que pode ser melhorado na terra indígena e serve como um interlocutor da comunidade, porque fala melhor o português.
} 


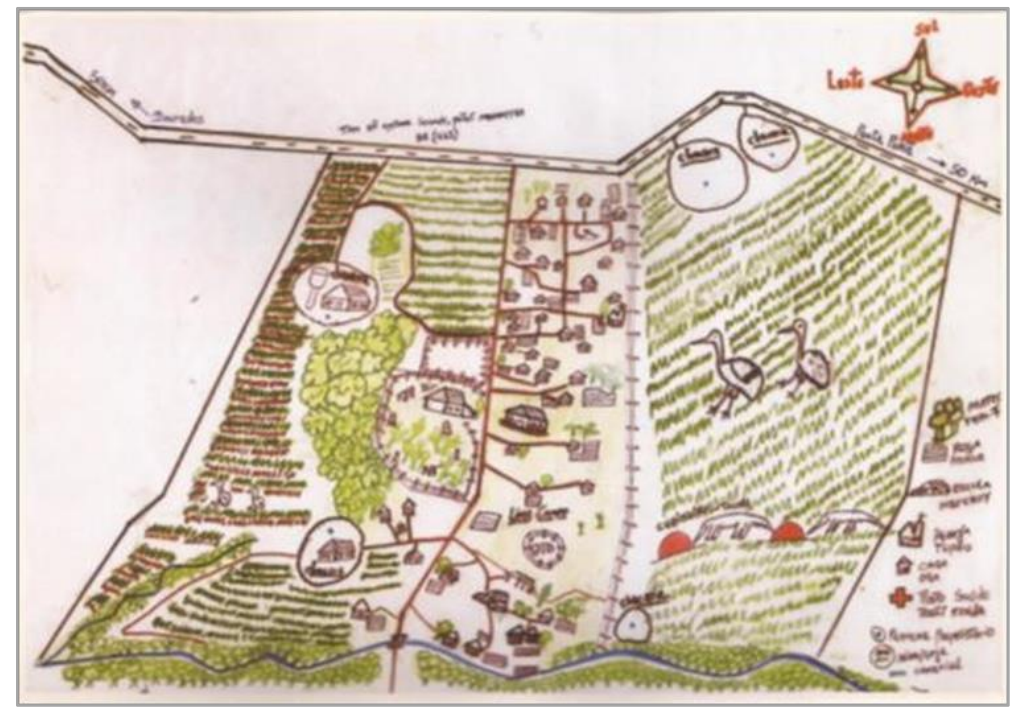

Croqui 3 - Cartografia étnica de Jatayvary. Fonte: GUARANI HÁ KAIOWÁ, 2011, p. 41

A escola já foi numa área em que existia um "barracão", perto do posto de saúde e no assentamento Corona, mas, hoje, os alunos de Jatayvary são atendidos na escola rural Graça de Deus que fica as margens da BR-463, em direção à cidade de Ponta Porã. A escola atende alunos da área rural da redondeza, vindos de assentamentos, sítios e fazendas. O ônibus da prefeitura transporta o professor e os alunos indígenas da $1^{\text {a }}$ a $4^{\underline{a}}$ série. Os demais alunos, da 5a a 9aㅡ série pegam o ônibus que vem das fazendas.

Ao visitar as instalações da escola, vi uma "tentativa de se fazer uma horta" no fundo das salas de aula, numa área que tem o formato de mandala. No momento da visita, alguns alunos com idade aproximada de oito anos estava fazendo a limpeza da área sob a supervisão de um professor. O professor indígena informou que os alunos de Jatayvary não fazem nenhuma atividade ligada ao meio ambiente.

Ele mostrou uma construção, hoje interditada, que funcionou como o primeiro lugar de sala de aula quando os alunos de Jatayvary passaram a estudar nesta escola, conforme fotografia a seguir. Os tijolos são aparentes e o banheiro fica colado com o espaço. Segundo ele, as condições eram muito ruins e na época quente se passava muito calor lá dentro. Ao analisarmos o local, a diretora ficou nos observando a uma curta distância e se adiantou ao dizer que aquele espaço não pertencia à escola e, sim a comunidade que fica ao lado. Ela ficou nos rodeando todo o tempo em que estivemos por lá. Chegou a nos mostrar uma sala de aula bem arrumada que contrastava significativamente com a sala em que o professor indígena trabalha. 


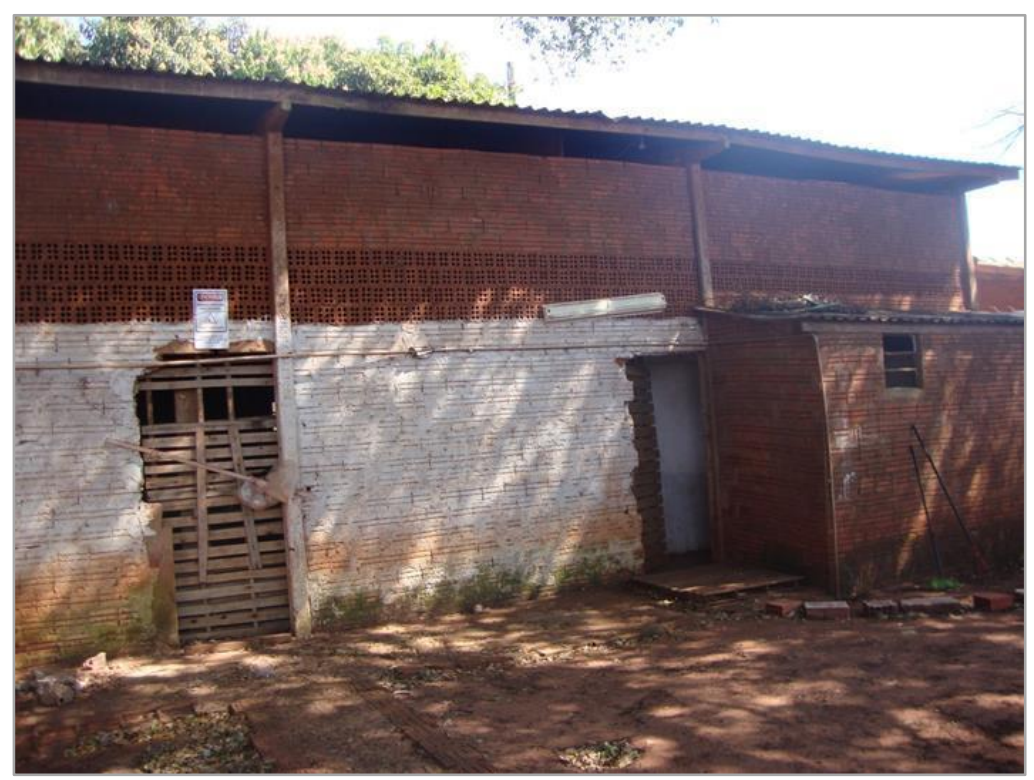

Fotografia 39 - Primeira sala de aula na escola Graça de Deus. Fonte: Autoria própria.

Sobre o atendimento aos alunos provenientes de Jatayvary, o professor esclareceu que no turno da manhã, estudam os alunos da $5^{\text {a }}$ a $9^{a}$ série e no turno da tarde, estudam os da 1aㅡ a $4^{\underline{a}}$ série. Ele ministra suas aulas, em português, à tarde para a turma da 1aㅡ série, que tem dezoito alunos matriculados e sua sala de aula fica logo na entrada da escola, do lado esquerdo. Para as demais séries, os alunos indígenas estudam misturados com os outros alunos da escola. Os demais professores são não-indígenas. A tendência observada pelo professor é a diminuição da quantidade de alunos de Jatayvary com o decorrer das séries.

O material didático não é bilíngue. Portanto, não traz nada específico sobre os conhecimentos indígenas. As reivindicações do professor são: a construção de uma escola na terra indígena; contratação de mais professores indígenas; aula bilíngue e material didático próprio.

Para o professor, existem recursos específicos para a educação escolar indígena, mas não é destinado a Jatayvary, pois, os recursos do FNDE vão para a escola Graça de Deus. O material, como lápis e caderno, para o aluno indígena não é comprado. Não só a falta de material é causa de evasão escolar, mas, principalmente, a necessidade de trabalhar por parte dos alunos. Em uma das conversas que tive no pátio da casa do professor, havia vários meninos adolescentes que deram seus testemunhos sobre as dificuldades de estudar, por isso, alguns desistiram. São muitos os desafios de se estudar numa escola mista: além da distância da escola; falta de material escolar e de roupa apropriada; ausência de professores indígenas e uma educação escolar diferenciada.

A comunidade formou uma comissão de lideranças formada por três homens, dos quais um deles é o professor. Na política interna, o professor, por ser de fora é mais neutro, 
por isso: "se dá bem com todo mundo." Ele observou que: "quando há divergência entre os mais antigos é difícil superar".

Há uma família composta por dois irmãos e uma irmã, na faixa dos cinquenta anos, que moram próximos à mata do lado direito da terra, bem próximo à área onde estão os colonos. Um deles ${ }^{109}$ compõe a comissão de liderança em Jatayvary e frequenta a Aty Guasu. Conversei bastante com ele. Em um momento, ele desabafou: "a comunidade indígena está abandonada pelo poder público". Criticou o município de Ponta Porã, o estado de MS e a Funai. Retratou que a comunidade enfrenta muitos problemas e enumerou: acesso à água, escola e roça; dificuldades para fazer documentos; arrendamento; questões de justiça e da terra e a relação com os colonos.

Essa liderança falou do caso de um índio que foi caçar e levou um tiro na perna na fazenda Menino Jesus, perto da rodovia. E, que foi a "fazendeirada" a responsável. Ele mesmo gosta de caçar e pescar, mas não passa para o lado da fazenda porque o pessoal atira por cima e diz que tem um motoqueiro que anda de madrugada por lá. Situação esta, descrita, recentemente, pelo Imad (2015, p. 48): "a falta de mata nativa tem forçado os indígenas à busca de lenha, madeira para construção e espécies fitoterápicas, além da caça de animais de pequeno porte, como pacas, cotias e aves, precisando se aventurar nas fazendas limítrofes, o que leva a constantes choques e ameaças de morte".

A liderança luta pela construção de uma escola na terra e disse que já escutou vários relatos das crianças se sentirem maltratadas na escola por conta dos brancos e citou o exemplo de discriminação no uso do banheiro. Ele reclama, juntamente com o professor, da existência de recursos a serem aplicados na escola indígena que estariam sendo destinados a escola Graça de Deus. Segundo a liderança, "usaram o nome dos índios" sobre a escola que não existe fisicamente em Jatayvary.

Sobre a situação da terra, a liderança lembrou que "depois que fazendeiro chegou aqui, encheu de gado, da vaca dele e braquiária, começou a desmatar e agora nós têm que usar trator também, né. Que no nosso muque a gente não vai vencer a braquiária não, né". E relembrou os tempos do seu pai, em que "a velharada fazia armadilha pra pegar tatu, anta dentro do mato, antigamente, não usava veneno, se rezava". Ele alcançou a época em que se rezava pra plantar, sendo que seu pai o ensinou. É o que ele chamou de herança dos velhos: "sem herança dos velhos como a gente vai viver". A roça ficava longe da casa: "os índios antigos pousavam por lá, tinha cachorrinho, caçava. O pessoal espantava formiga com a reza".

\footnotetext{
${ }^{109}$ Ele fala firme, com o rosto sério; critica o governo, as instituições, mas solta um riso natural, alegre mesmo com todas as dificuldades. Faz brincadeiras mesmo diante de toda a dureza da vida numa terra em litígio. Se preocupa com a "criançada" de Jatayvary e se sente responsável pela comunidade. Tem um modo de falar bem peculiar. Usa sempre o sufixo "ada" ao final de alguns substantivos como: criançada, sobrinhada, braquiarada, fazenderada. Ele se compara a um bugiozinho, porque é pequenininho, mas fala alto.
} 
Aproveitando a oportunidade, perguntei: reza funciona para a braquiária? Ele respondeu: "pra essa braquiária quem serve pra ela é a máquina, o trator, né. Pra braquiária não tem reza. Hoje tem veneno, que é imediato. Pra produzir o dinheiro tem que ser na máquina, né".

A liderança e o professor são bem afinados e, juntos conversaram sobre alguns aspectos culturais. Apesar de ser bem jovem, o professor disse que hoje as crianças não querem nem fazer tereré para o pai, não querem mais ouvi-lo: "antigamente, todo dia de manhã a criança recebia um conselho pra sua vivência. Outro dia, outro conselho ao redor do fogo. Essa vivência vai crescendo". Mas hoje, as crianças preferem jogar bola e assistir televisão. A diferença está muito grande entre as gerações ${ }^{110}$. Para o professor: "se for usar novamente a cultura indígena, não pode se intrometer: lideranças indígenas, associações, conselho tutelar, secretaria de educação do município, a justiça não pode se intrometer". Para ele: "antes o filho tinha que escutar o pai, o tio mais velho, a família pra tomar uma atitude e, hoje se alguém me ver batendo no meu filho e me filmar vai ponhar no facebook, na internet, vai me denunciar no conselho tutelar, vai recolher meu filho".

O professor também refletiu sobre a alimentação e o estilo de vida: "o que mudou hoje é porque pro homem ficar forte e trabalhar no muque a gente não comia coisa frita, só cozido ou assado. E não existia macarrão, trigo. O que deixava a pessoa ter mais muque era fruta nativa, que se achava no mato". Seguiu seu o raciocínio sobre saúde: "a mesma coisa o remédio pra cada cura que se achava também no mato. E hoje não. Se a pessoa tiver uma dor de cabeça, vai no médico, procurar o posto". E lembrou que para cada tipo de alimentação tem a reza para caçar, para pescar, para plantar e colher.

Liderança e professor concordaram: era melhor quando a Funai e o MPF que atendiam a comunidade eram de Dourados. Depois que eles passaram a fazer parte do CTL da Funai de Antônio João e o MPF de Ponta Porã a comunidade de Jatayvary foi abandonada. As lideranças da terra reclamam que fica longe e custoso ir à Funai de Ponta Porã e mais ainda para a CTL no município de Antônio João e que os servidores não fazem visitas periódicas a Jatayvary. Por isso, a conversação girou muito em torno das reclamações e das dificuldades na obtenção de serviços. Pelo fato do meu tradutor ser membro da Aty Guasu, os indígenas de Jatayvary com quem conversei, pediram para que o mesmo fizesse encaminhamentos.

\footnotetext{
110 Conforme Tonico Benites (2009, p. 59): "no processo de transmissão de conhecimento, as lideranças e suportes agregadores e protetores, como o avô (tamõi) e avó (jaryi), pai (ru) e mãe (sy) das crianças são pessoas fundamentais, com autoridade para intervir nos problemas internos conforme as normas morais estabelecidas pelas mesmas. Estas pessoas são consideradas como "líderes-orientadores" legítimos pelos seus membros internos".
} 


\subsubsection{Plantação de fazendeiro}

Para a liderança, em Jatayvary, tem uma "plantação de fazendeiro". A terra está cercada por fazendas e na área onde ele vive, que está fora da área dos 181,43 ha, os conflitos são constantes. É a região que foi loteada para colonos pelo antigo Banco da Terra. Por ocasião da visita em 2013, pude verificar que o roçado da família estava queimado. Segundo a liderança, o colono alegou que a terra pertencia a ele e, por isso, é frequente ele fazer queimada e passar veneno, atingindo as roças de mandioca indígena. Houve risco de queimar as casas da família da liderança e a matinha que, ainda, resta, pois, com a braquiária, o fogo se espalha mais rápido. Meu interlocutor relatou que os colonos não o respeitam e que o presidente dos colonos incentiva a briga com os índios. Ele cita o nome de três colonos que são mais agressivos. Para a liderança, seria importante que estes colonos não tivessem mais acesso a financiamento para plantar nas terras de Jatayvary.

Outra situação que a comunidade enfrenta, é o arrendamento de parte dos 181,43 ha para o plantio de soja. Segundo a liderança, alguns indígenas que moram na comunidade, arrendam terra para brancos e dispõem de toda uma infraestrutura para lavoura, como máquinas colheitadeiras. Um dos indígenas, que faz o arrendamento de cerca de 12 ha, já afirmou: "índio não sabe trabalhar". Este indígena possui alguns sinais de riqueza, como trator, maquinário, carro e casa melhor, que contrasta com a vida dos demais moradores. $\mathrm{A}$ liderança entende que não deveria ter arrendamento na aldeia. Cada um poderia morar em qualquer lugar, porque não está demarcado.

Essa situação gera distorções graves, principalmente, devido ao processo de luta que a comunidade enfrentou e nos seus inúmeros desafios vivenciados ao esperar a solução definitiva da terra a que tem direito. Sem contar nos conflitos políticos gerados para parte da comunidade que não concorda com essa prática. Segundo a liderança, indígena que arrenda terra: "não tá certo com a comunidade. Isso explora os índios. A comunidade reclama". A Funai, prosseguiu a liderança, deveria: "ficar de olho nele e tomar a colheitadeira. Já faz tempo que ele tem essa prática. Ele quer ser maior que as autoridades, pois, todos os órgãos sabem disso, mas não é feito nada". Isto gera uma situação de desconforto com as demais pessoas da comunidade e, além disso, os arrendatários usam agrotóxico nas plantações. A liderança relembrou que eles estão nessa terra "pela força da comunidade".

Segundo a liderança, ocorreu, recentemente, na comunidade o caso de um indígena paraguaio, casado com uma kaiowá, ter derrubado árvores da mata, inclusive, de madeiras nobres, como aroeira. Numa caminhada que fizemos na mata, o professor me indicou várias clareiras que mostravavam a derrubada de árvores, conforme foto a seguir. $\mathrm{O}$ grupo com quem conversei, também denunciou a coleta, por esse mesmo indígena, de plantas 
medicinais em grande quantidade para vender. É um caso de retirada de recursos naturais dentro da terra indígena com exploração de madeiras nobres e de plantas que servem de remédio tradicional.

A liderança explicou: "a comunidade chega mais pra mim, pra denunciar, fazer denuncia do pessoal que tá tirando madeira boa de aroeira, de madeira de lei, fazendo desmatamento. A comunidade também levantou contra isso. Não pode né. Tudo que tem aqui é da comunidade". Ele prosseguiu narrando sobre a atitude do indígena:

começa a tirar aroeira, cedro, madeira boa, madeira de lei. Começa a vender pro outro lado, né? Assim, a comunidade reclamou. Pra vender, vendeu muito daqui. Veio a polícia florestal e descobrimo onde tava rachando a madeira aroeira. E chegamo em cima dele. Além disso, ele colocou um companheirinho também daqui mesmo. Deu $\mathrm{R} \$ 10,00$ pra acompanhar ele pra achar a aroeira. Agora ele parou, não fazer mais nada, movimento.

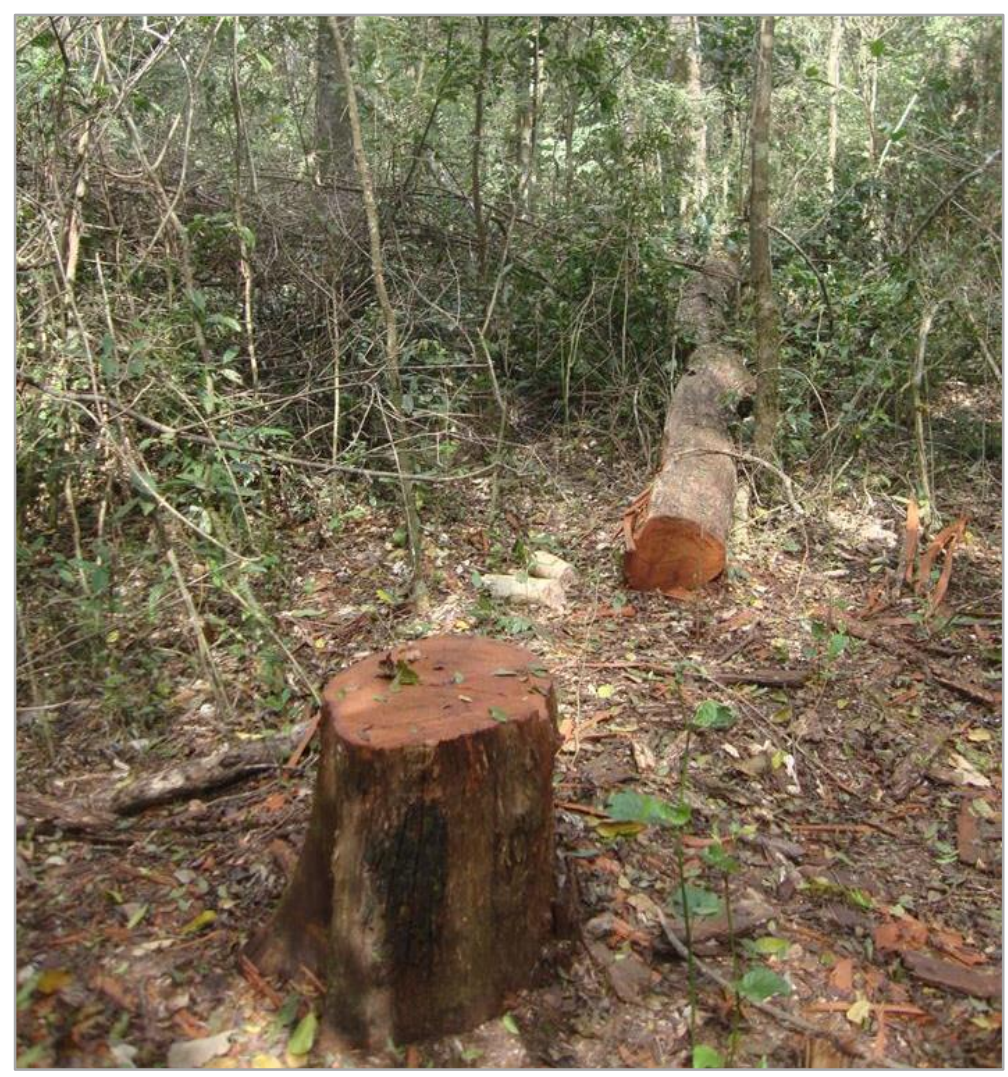

Fotografia 40 - Árvore derrubada na mata.

Fonte: Autoria própria.

A mata que resta do "lado do loteamento" encontra-se muito ameaçada. Há riscos constantes de queimadas por parte dos colonos que, ainda, ocupam a área. Além disso, como a comunidade não dispõe de recursos para fazer e manter suas habitações, precisam de madeira que, geralmente, é retirada desta mata. Lá não há mais sapé. A mata também é procurada para a coleta de alimentos e de plantas medicinais. A liderança falou com 
reverência: "a mata é nosso segredo. Nossa mata é nossa saúde". Relembrou que quando chegou a Jatayvary, há pouco mais de quinze anos: "o mato era na beira do córrego. A fazendeirada destruiu tudo. O branco não tem dó pra destruir. Eles derrubaram a mata e jogaram a braquiária aqui".

Outra ameaça constante é o tráfego de veículos. Passam muitos caminhões nas estradas dentro da terra indígena por conta das fazendas que estão no entorno. Eles levantam muita poeira. Há risco de atropelamento, pois, muitas crianças circulam livremente nestas áreas.

Em outra situação, visitei dois irmãos pertencentes à família que lutou pela retomada de Jatayvary, cujos pais com mais de oitenta anos, moram numa casa ao lado de um dos filhos. O casal de idosos falou pouco e os próprios filhos tem dificuldade de entendê-los. $A$ família é composta por seis irmãos vivos de um total de oito. Hoje em dia, a maioria mora em Jatayvary. O irmão mais novo lembrou: "nós somos família daqui. Nós morava tudo junto. Aí tinha um parente que ficava alí. Mas era tudo parente. Como uma comunidade. Mas depois uns foram saindo, indo pra outros lugares". Ele e o irmão foram os últimos a ficarem por lá.

O irmão mais velho lembrou que quando era criança o pai fazia coivara para plantar: "nosso pai roçava. Aí fazia. Hoje em dia não. Hoje em dia não tem mais". As casas desta família extensa margeiam uma vasta plantação de cana-de-açúcar e o contraste é muito marcante, pois, a cana estava bem perto das casas, como pode ser visto na fotografia a seguir. Esta é uma região tradicional, chamada de Rancho Kuña. O irmão mais velho revelou: "ali antes de ser cana, era vaca que trouxe a braquiária". O irmão mais novo lembrou: "onde é o canavial, era um guaviral. Lá no fundo ainda tem, sobrou, um pedacinho de guavira". E o outro, complementou: "tinha também araticum, erva, tudo. Acabaram, plantaram, limpou tudo".

O mais velho chegou a trabalhar em fazenda de gado nas redondezas e, afirmou: "em 79 não tinha lavoura, era só gado. E, começamo a fazer lavoura. Nós catemo aí de guavira. Aí ninguém me engana porque conheço tudo por aqui. Em 80 começou os índios a tirar o mato na fazenda. E os índios não tinham mais roça para trabalhar, para manter a família. Começou a morrer criança". Para o irmão mais novo: "antes o fazendeiro deixava o índio fazer uma casa na fazenda para trabalhar para ele. Hoje em dia não dá mais barraco. Pega o índio na aldeia para trabalhar e depois devolve". 


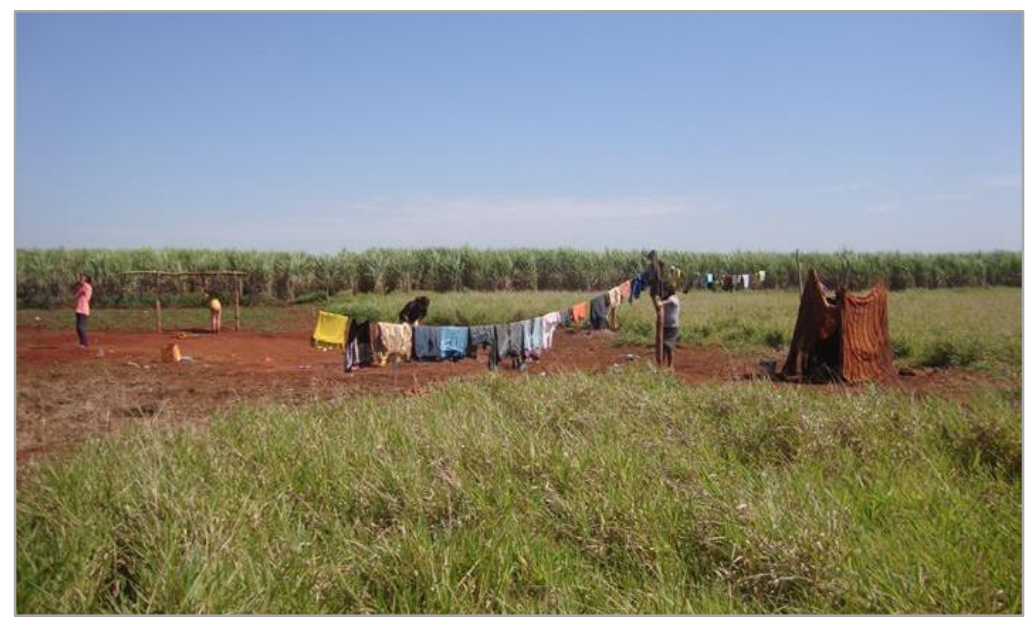

Fotografia 41 - Limite entre a plantação de cana-de-açúcar e a casa da família.

Fonte: Autoria própria.

Eles são uma das poucas famílias que conseguem viver das suas roças. Possuem um poço d'água e plantam feijão guandu, mandioca, algumas frutíferas e outros cultivares. $O$ irmão mais novo reafirmou o sentimento com a terra: "já nasceram alí, já acostumou, não pode ir para outro lugar. Qualquer coisa tem que aguentar tudo alí. Tem que passar alguma luta, sofrendo, mas tá aí. Pode ser que mais pra frente melhore alguma coisa. Vai esperando, né? A comunidade não incomoda fazendeiro".

\subsubsection{Pastagens e campos de monocultura}

A transformação das paisagens na área declarada de ocupação tradicional Jatayvary passou por processos semelhantes vivenciados por todo o sul de MS. Porém, com o agravante da repartição de uma área extensa em fazendas que passaram a explorar intensamente o solo para pecuária, produção de grãos e, mais recentemente, plantio de cana-de-açúcar. A topografia plana e os solos férteis favoreceram a instalação de plantios com utilização de forte mecanização.

A herança deste modelo é percebida pelos indígenas através de solos degradados com muita presença de braquiária e formigueiros; perda de vegetação e de biodiversidade como um todo; contaminação dos córregos e uso de agrotóxico. E o mais grave para esta terra é que este legado continua a produzir intensamente seus efeitos no presente. A não regularização total dos 8.800 ha faz com que os 181,43 ha estejam "ilhados" em vastos campos de monocultura, que seguem a produzir seus rastros de destruição. Por ocasião do Relatório de Identificação e Delimitação, Thomaz de Almeida (2005, p. 86), descreveu:

Observando a imagem de satélite da área podemos inferir que de toda a área em estudo $60 \%$ é utilizado para culturas anuais, 30\% é ocupado com pastagens e $10 \%$ como áreas de preservação permanente. A legislação 
ambiental exige que $20 \%$ da área total da propriedade seja destinada para Reserva legal e as áreas de nascentes, olhos d'água são áreas de preservação permanente e que também devem ser consideradas independente dos $20 \%$ da reserva legal. Em muitas propriedades houve desrespeito total da legislação ambiental. Foi observado durante os trabalhos que ainda existe a exploração de madeiras nas áreas de reserva legal e preservação permanente.

Originalmente, a região era caracterizada pelo bioma mata atlântica, com florestas estacionais semidecíduas, mas possuia também a vegetação nativa composta de cerradão, cerrado, campos úmidos e matas de galeria. Está inserida na bacia hidrográfica do rio Dourados, cujas nascentes, presentes na área em estudo, encontram-se quase que totalmente sem vegetação, assim como as matas ciliares que passam por fortes impactos ambientais. "Provavelmente, a região foi muito rica em pacas, capivaras, antas, tatus, cutias, tamanduás, araras, emas, gaviões, papagaios, seriemas, tucanos e muitas outras espécies animais. A área é rica em abelhas nativas ou sem ferrão" (THOMAZ DE ALMEIDA, 2005, p. 87).

Atualmente, a área dos 181,43 encontra-se bastante descampada, o que favorece a propagação de incêndios. Percebe-se uma ínfima vegetação da mata ciliar no córrego Jatayvary e uma ampla área desmatada, conforme o mapa georreferenciado, de autoria do professor da UFGD Joelson Gonçalves Pereira. A nomenclatura "solo sem vegetação" corresponde à área de roças.

Conforme cálculos do Imad (2015, p. 49), da área de 181,43 ha, 135,01 ha da terra estão desmatados, ou seja, 74,92\%; 39,62 ha estão sem vegetação (com roças), o que corresponde a $21,98 \%$ e apenas 5,58 ha ou seja $3,10 \%$ de floresta. No lado oeste há uma extensa área composta por plantações de cana-de-açúcar e, pelo lado leste existe a presença de pastos. Segundo informações do Imad (2015, p. 45):

a utilização do veneno (herbicidas, inseticidas e maturadores) aspergido por avião agrícola nas lavouras de cana causa, entre outras coisas, doenças respiratórias e a invasão de insetos na $\mathrm{Tl}$, e quando colocado no solo alcançam o lençol freático assim como é levado para o córrego através do lixiviamento. Todo esse processo afeta diretamente a produção agrícola da TI Jata'yvary. Isso sem falar na constante poeira, em tempo de seca, causada pelos pesados caminhões que perpassam a aldeia transportando cana para a usina. 


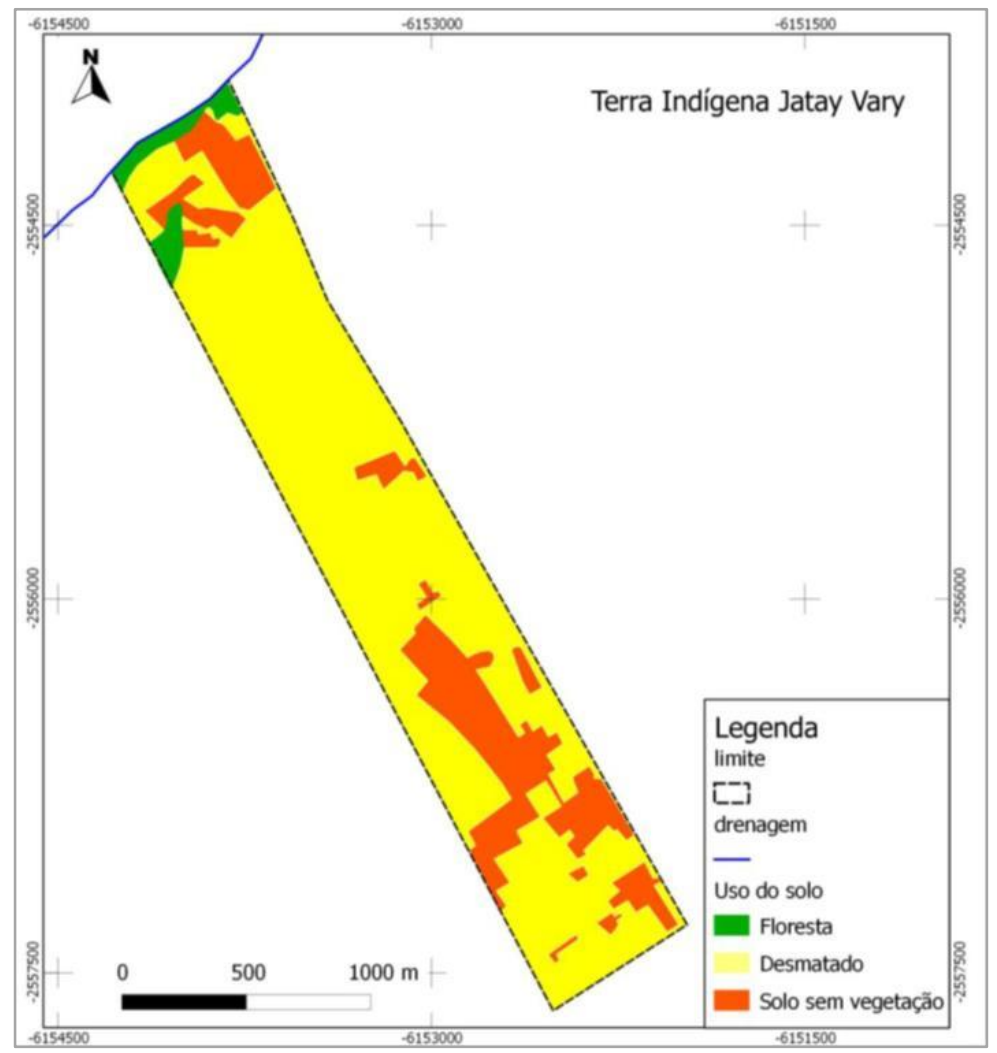

Mapa 5 - Cartograma do uso da terra de Jatayvary (georreferenciado). Fonte: IMAD, 2015, p. 49.

A vasta plantação de cana-de-açúcar dentro e no entorno da terra indígena é um indicativo da cadeia de plantio, processamento e industrialização que existe na região ${ }^{111}$. Muitas terras foram arrendadas para o plantio de cana-de-açúcar para as usinas Monteverde (Bunge) e São Fernando. Há poucos quilômetros dali, também, se encontra uma usina de cana-de-açúcar da Bunge ${ }^{112}$.

Além disso, também há muito plantio de soja no entorno e na própria terra indígena, dentro da área delimitada, mas que, ainda, não foi regularizada. A percepção de uma terra indígena ilhada pode ser sentida na fala de diversos moradores. Para o professor: "o canavial tá abraçando a gente." Ele sugeriu uma indenização por parte da Bunge para que a comunidade possa ter acesso a "um tratorzinho para fazer roça e uma escola". A liderança se referiu as duas empresas canavieiras da seguinte forma:

a Bunge quis desmatar completo para plantar cana. A São Fernando quase desmataram de nós aqui. Aí entrei, denunciei ele. Foi a São Fernando que

\footnotetext{
111 "A produção agrícola não está a serviço das necessidades das comunidades, respondendo a interesses econômicos globalizados, movida pelas commodities do agronégocio. Ela produz grãos para exportar e/ou alimentar animais para a produção de carne ou para produzir energia renovável para mover os carros." (JUNGES, 2010, p. 57).

112 Recentemente, uma equipe da Oxfam inglesa esteve na região e pode ver in loco as relações entre o plantio da cana na terra indígena Jatayvary e a usina da Bunge, multinacional que recebe financiamento de vários bancos internacionais, inclusive do Rabo Bank da Holanda, o que motivou várias reportagens sobre o assunto naquele país.
} 
ia desmatar. la terminar o que tinha aqui. Pra desmatar tudo isso aqui pra encher de canavial. Aí a comunidade levantou lá. A comunidade também preserva esse lugar, né? Aí vai desmatar, vai acabar terminando tudo mesmo. Que ele quase derrubou todo esse mato aqui.

Em 2011 foi realizado pela Funai um Relatório intitulado: "A percepção indígena em relação aos impactos do plantio de cana-de-açúcar na terra indígena Jatayvary", com o objetivo de identificar os impactos negativos causados pelo setor sucroalcoleiro sentidos pelos indígenas de Jatayvary. Foram percebidos impactos negativos nos três subsistemas da cadeia agroindustrial: agrícola, industrial e transportes. Tais impactos foram resumidos por tema da seguinte forma: a) queimadas: ocorreu uma vez e causou problemas respiratórios na comunidade; b) agrotóxicos: ocorreram dois sobrevôos, mas desconhece-se o teor das substâncias lançadas, utiliza-se agrotóxicos nos cultivos na divisa da terra indígena, apresentação de pessoas com sintomas de dores de cabeça, enjôo e alergias; c) colheita mecanizada: ocorre dia e noite, emitindo ruídos altos; d) caminhões canavieiros: provocam ruídos altos, suspensão de poeira e problemas respiratórios (MARTINEZ DOS SANTOS, 2011, p. 13).

Posteriormente, a Funai verificou a ausência da inclusão da terra indígena na área de influência direta da usina Monteverde (Bunge) no seu estudo de impacto ambiental que foi aprovado e licenciado pelo IMASUL. Os empreendedores alegaram que só havia indígenas na área de influência indireta. Além disso, o órgão indigenista não foi consultado, como interveniente, no procedimento de licenciamento ambiental. Tais fatos caracterizam desrespeito a normas constitucionais e a legislação que regulamenta o estudo de impacto ambiental e o licenciamento ambiental. Por isso, a Funai solicitou o cancelamento e a nãorenovação das licenças de operação concedidas a ambas empresas até a regularização do componente indígena no licenciamento ambiental dos empreendimentos. Fato que não foi realizado.

A partir dos anos 2000 houve um aumento considerável das áreas de plantio e da instalação de usinas sucroalcooleiras em MS, que se tornou o segundo estado do Brasil com maior área de plantio, atrás de São Paulo. Esta expansão ocorreu no sul de MS, onde há a maior reivindicação pela demarcação de terras indígenas Kaiowá-Guarani. Os estímulos financeiros, tributários e creditícios foram realizados em nível federal e estadual para a produção do etanol, identificado como um combustível limpo, renovável e sustentável.

Fazendas em terras reivindicadas ou em terras já identificadas e delimitadas, mas não regularizadas devido a longas batalhas judiciais, como é o caso de Jatayvarry, realizaram contratos de parceria e arrendamento com usinas para o vasto plantio de cana-de-açúcar, expandindo uma nova fase de colonização das terras indígenas. 


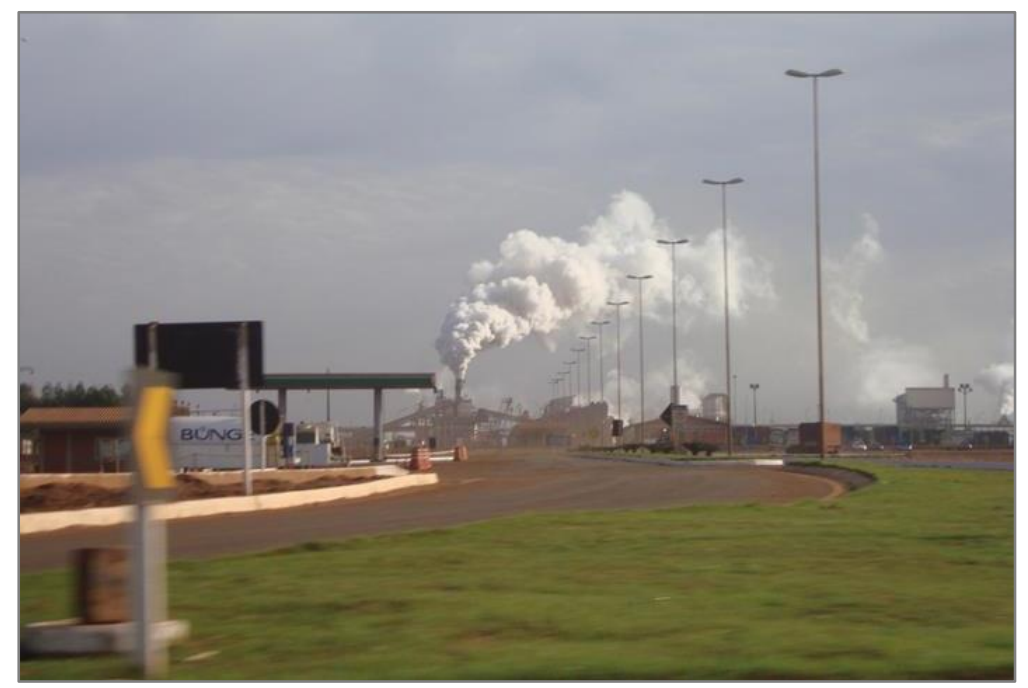

Fotografia 42 - Usina Monteverde/Bunge. Fonte: Autoria própria.

A geopolítica do etanol estimulou, também, a expansão do setor sucroalcooleiro em MS, de certa forma, devido à proibição da sua instalação na Amazônia, no Pantanal e na Bacia do Alto Paraguai pelas regras previstas no Zoneamento Agroecológico da Cana-deAçúcar, Decreto 6.961/2009. Este decreto também proibiu o plantio em terras indígenas, mas os atrasos nas regularizações fundiárias das terras indígenas reivindicadas no sul de MS estimulam o avanço das vastas plantações desta monocultura sobre, inclusive, terras já identificadas. Um pequeno alento veio com a Resolução 3.804 de 28/10/2009 do Conselho Monetário Nacional que impede, a partir da data da sua publicação, bancos públicos e privados de financiar o setor sucroalcooleiro em terras indígenas.

Aos plantios, o órgão ambiental do estado - IMASUL, não exige o licenciamento ambiental, nem tampouco o estudo prévio de impacto ambiental. Não há previsão expressa nem na legislação federal, nem estadual, porém, o recomendável seria exigí-los com base no poder discricionário a ser exercido pela administração pública para concretizar o direito constitucional ao meio ambiente ecologicamente equilibrado. Quanto às usinas, a formalidade tem exigido os instrumentos de comando e controle da normativa ambiental, acima referidos, mas a presença indígena nas suas terras ou é desconsiderada; ou se alega que não faz parte da área de influência direta do empreendimento ou, simplesmente; é feito um relatório padrão e genérico, sem aprofundar os prováveis impactos do setor.

A Ong Repórter Brasil (2010, p. 54-6) realizou vários relatórios sobre os impactos socioambientais das monoculturas de soja e cana-de-açúcar em terras indígenas de MS, onde identificou inúmeras violações de direitos trabalhistas, indígenas e ambientais e, verificou a presença de contratos de arrendamento das fazendas que incidem em Jatayvary pelas usinas São Fernando e Monteverde/Bunge. 
A usina São Fernando se comprometeu, em abril de 2010, através de termo de ajustamento de conduta com o Ministério Público, a não "adquirir ou promover o plantio de cana-de-açúcar, mesmo por intermédio de contratos de arrendamento, em imóveis rurais que estejam localizados em áreas identificadas, declaradas ou homologadas como terras tradicionalmente ocupadas pelos índios" (ONG REPÓRTER BRASIL, 2012, p. 9 e 13). Já a Monteverde/Bunge, situada a cerca de $14 \mathrm{~km}$ da terra indígena, manifestou-se da seguinte forma a respeito dos contratos de arrendamento de terras em fazendas situadas na área identificada e delimitada de Jatayvary: "quando houver decisão definitiva das autoridades competentes a respeito da propriedade das terras, e se esta for favorável aos indígenas, a Empresa imediatamente tomará as providências necessárias à suspensão dos respectivos contratos, caso ainda estejam em vigor" (Idem).

\subsection{O GUAVIRAL RESISTE}

Por ocasião do campo prévio, em dezembro de 2013, tive oportunidade de acompanhar o professor e uma das moradoras ao chamado guaviral. Nesta época do ano, as frutas de guavira ${ }^{113}$ estão maduras para serem colhidas. Em uma área ao lado direito da terra, onde poucas famílias indígenas residem, devido à vizinhança com os colonos remanescentes e os constantes conflitos, resiste uma área importante para a comunidade onde no meio da braquiária estão vários pés de guavira, conforme fotografia abaixo.

Além de guavira, podem ser vistos outros frutos nativos do cerrado como o araticum. $\mathrm{Na}$ época da colheita, a comunidade se reúne para coletar junto com as crianças e, passam o dia por alí, comendo as frutas e tomando tereré. Há uma árvore frondosa e de pequeno porte que eles ficam em baixo da sua sombra se confraternizando. Segundo uma moradora, há duas espécies de guavira e duas de araticum nativos. Ela demonstrou muito conhecimento sobre as plantas e parecia feliz em mostrar os nomes das árvores, como jatobá e, outras plantas, como barbatimão. Os bovinos dos colonos também circulam por lá apesar de não termos visto nenhum, mas sua presença poderia ser sentida devido à braquiária estar baixa.

\footnotetext{
${ }^{113}$ Destaco as referências sobre a guavira narradas por Nimuendaju sobre a lenda da criação. Em um diálogo entre os gêmeos: "XIX. E ele caminhou novamente e pisou novamente contra uma árvore e fez guaviraeté. Ele as provou novamente: "Também elas são (demasiado) carnudas, irmão!" E andou novamente e pisou contra uma árvore e fez guaviraju. Ele as provou novamente: "Estas sim, são um pouco doces para mim!" XX. E ele foi e trouxe as guaviraeté e guaviraju. As guaviraju, que ele tinhas trazido, ele escondeu da avó-onça, as guaviraeté, que ele tinha trazido, ele mostrou à avó-onça" (UNKEL, 1987, p. 146). Em outra passagem: "XXIV. E então: "Sempre avante, irmãozinho!" Ele foi e trouxe guaviraeté para a avó. "De onde vocês as trouxeram, meu neto?"- "Trouxemo-las do outro lado da grande fonte." - "São muitas, as que vocês acharam?"- "Achamos muitas lá". - "Vamos amanhã apanhá-las para vocês!" E a Onça Prenhe (disse): "Se já não estivesse escuro, eu iria já, de manhã, sim, vamos"' (Idem, p. 147).
} 


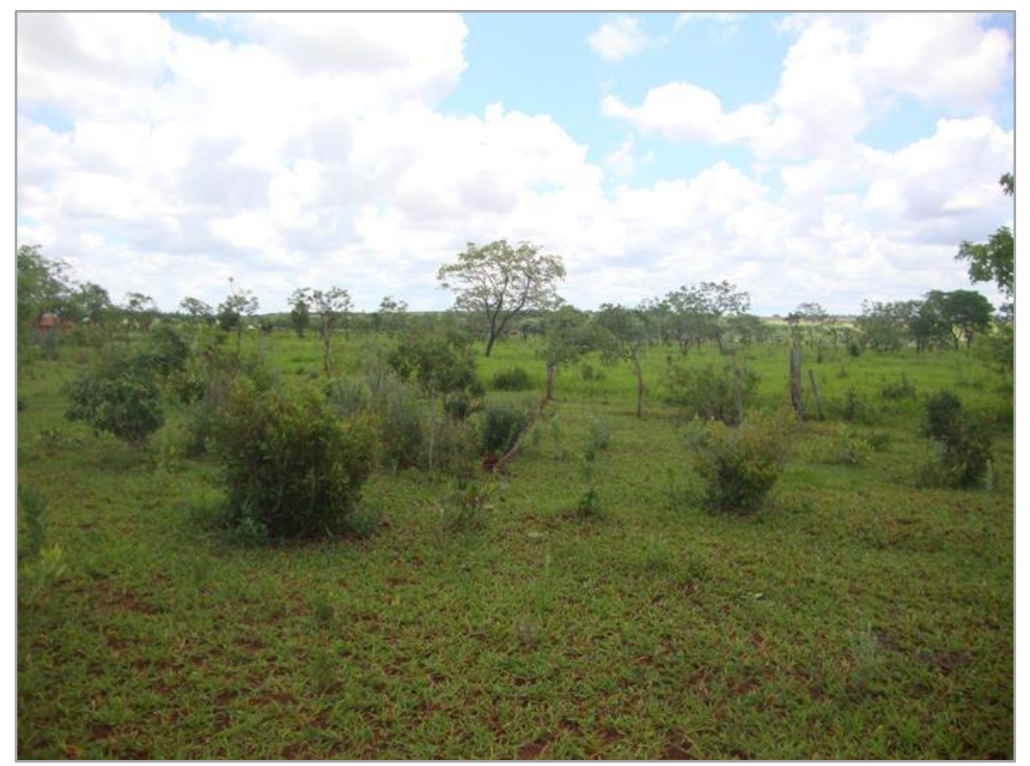

Fotografia 43 - Guaviral. Fonte: Autoria própria.

Os moradores do lado direito, pela proximidade da matinha, percebem melhor o que acontece a ela, como queimadas ou desmatamentos. Por sua vez, utilizam os seus recursos, como lenha (a maioria não tem fogão a gás) e retiram da mata os remédios que precisam.

Em outra ocasião, já na pesquisa de campo de 2014, realizei com o professor, a liderança e a rezadora caminhadas nesta mesma área, que eles chamam de "cerradão". A rezadora foi nos mostrando diversas plantas medicinais que encontrava pelo caminho, indicando "para que servia". Dizia o nome em guarani e, meu tradutor ou o professor traduziam para o português ${ }^{114}$. Impressionou-me a presença de diversas plantas e tipos de pequenas árvores entre a braquiária. Neste período, o mato estava bem alto. Diferentemente, do ano anterior em que ele estava bem baixinho. A explicação que me deram foi a de que o gado não estava pastando por ali, por isso não haviam comido o mato. No local, o guaviral estava quase irreconhecível pelo tamanho do mato que o encobria e também por não ser a época de colheita da fruta.

O professor aproveitou a aula ao ar livre para aprender mais sobre a identificação, o nome de plantas e árvores e as propriedades de cura. Anotava tudo no seu caderno e eu copiava dele a grafia em guarani. Ele parecia bem encantado e curioso porque não conhecia a maior parte das plantas que a rezadora mostrava. Disse para ele que seria interessante fazer atividades com os seus alunos utilizando este material, ao que pareceu entusiasmado. Outro que estava com esse ânimo foi o tradutor, que manteve a curiosidade em aprender. O

\footnotetext{
114 Sobre algumas das plantas encontradas, de acordo com a grafia do professor: ñaracatigy, algodãozinho, serve para reumatismo; timbó, barbatimão, serve para ferida: tupã ypy, para dor de barriga; canica de cadela, para parar de beber; mborevipó, mão de anta, para dor de barriga; guassu nambi, orelha de veado, serve para gripe; mba'eka, para falta de apetite; jurubeba, para dor de barriga.
} 
tradutor e o professor relembraram quando os seus pais falaram de algumas plantas para eles, quando crianças. Em muitos momentos eles esqueceram que eu estava ali e ficaram falando só em guarani.

Este episódio, de certa forma, revela que as gerações mais novas, mesmo os professores, não sabem muito bem o conhecimento sobre as plantas, as árvores e os bichos. Existem dificuldades para socialização desse conhecimento, como decorrência, dentre outros fatores, da ausência ou degradação das matas. Nem sempre este conhecimento chega à educação escolar indígena.

$\mathrm{Na}$ abertura de caminhos no cerradão, a rezadora mostrou o que encontrava: plantas, cipós, folhas, cascas, raízes e resinas. Bem como os usos: chá, banho, colocação direta na pele, dentre outros. Há uma variação nos usos de acordo com a propriedade a ser utilizada. Mas, em todo caso, a adoção da planta como remédio deve ser seguida da reza.

Esta área já foi fazenda de gado, daí a existência da braquiária. Mas mesmo assim, várias plantas medicinais podem ser encontradas. Há um contraste entre o diverso e o monocultural: a riqueza de espécies nativas, inclusive de saberes como o uso medicinal atribuído pela rezadora, e a área de monocultura de cana ou de soja por todos os lados.

A matinha com essa área de cerradão composta por campo, pequenas árvores e muitas plantas medicinais pode ser vista na fotografia abaixo. Muitas plantinhas minúsculas estão escondidas no meio da braquiária. São muitos os contrastes perceptíveis pelos sentidos: visuais, de temperatura, de cores, de odores..., entre a terra em que estão presentes o gado e a monocultura e a terra que resiste, mesmo diante de todas as adversidades, com a matinha e sua diversidade.

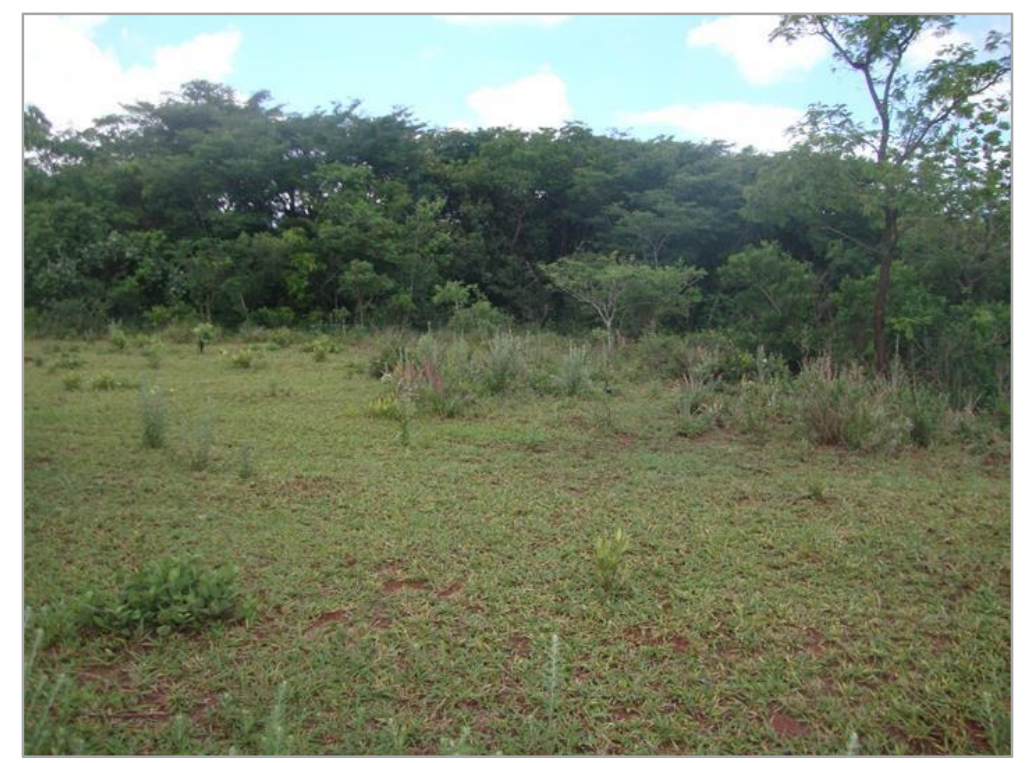

Fotografia 44 - Braquiária, plantas nativas e mata.

Fonte: Autoria própria. 
A diversidade se manifesta de diversas formas: na natureza e nas suas propriedades curativas; no seu simbolismo; nos saberes; nas formas de se manejar e de ser manejado entre plantas e homens; na sua reverência; na sua importância para ser e estar na terra e na diferença de tratamento que é dada a terra e aos seres vivos.

A liderança afirmou: "a mata é a farmácia natural dos indígenas. Esse mato fica tudo dentro de nossa aldeia. Se derrubar bastante vai acabar a nossa mata. A mata é nosso futuro. Nosso desejo é a preservação". Ele falou com entusiasmo que sua irmã conhece os remédios do mato e a sabe rezar. Eles sonham com a construção de uma casa de reza em Jatayvary $^{115}$. O pai a ensinou a rezar e, ela por sua vez ensina a filha. Mas está difícil conseguir sapé para construir a casa de reza. A liderança pensou na importância da casa para ensinar novamente a tradição: "a criançada lá fora não aprende o que é a tradição". E prosseguiu: "antigamente a nossa mata era grande. Hoje tem que saber o que tem. Hoje pra quem sabe ainda tem", referindo-se a plantas medicinais, principalmente, na beira do córrego. Quando é possível e dispõe de recursos, a rezadora faz chicha de milho utilizando um pilão que tem na casa de um idoso conhecido. Promove a reza e convida as pessoas da comunidade, mas os "crentes" não vão para o pátio da sua família.

$\mathrm{Na}$ terceira caminhada a este local, me acompanharam o professor e um casal de indígenas que moram bem próximos à mata. Eles conhecem bastante sobre as plantas. Ela revelou: "o meu guri também cresceu com os remédios do mato. Se não saber ninguém remédio caseiro, aí tem que levar direto pro doutor". Ela faz parte de uma das famílias de ocupação tradicional de Jatayvary e lembrou: "aqui era tudo mato. Depois que o fazendeiro traz o trator e aí derruba. Aí ficou assim mesmo. Ficou desse jeito".

Das matas nativas restou pouco em Jatayvary, o ciclo de devastação segue produzindo seus efeitos e se espalhando. A própria comunidade, ilhada, em sua maioria, sente a importância das matas, mas sem alternativas, exerce pressões sobre o que resta delas. Nas falas de todos com quem conversei, percebi como se deu o processo de ocupação sobre as terras tradicionais, seguindo um ciclo sucessivo, mas também com temporalidades concomitantes, como se pode observar na atualidade: fazendas de gado plantações de soja - cana-de-açúcar.

É urgente criar e implementar sistemas protetivos do que, ainda, resta da mata que está do lado direito, fora dos 181,43 ha, mas que faz parte da área dos 8.800 ha identificados e demarcados. Lá estão os últimos remanescentes dos guavirais nativos da

\footnotetext{
${ }^{115}$ A rezadora confirmou que gostaria de uma casa de reza. Seria também um lugar para mostrar os remédios, pois, os remédios caseiros e a reza estão se acabando. Ela percebeu que hoje tem menos remédio. $O$ que sobrou tem que ter o conhecimento para identificar. O remédio na beira do rio, no varjão é o que tem mais. Mas mesmo assim, a rezadora costuma leva remédio para uma das filhas e sobrinhos que moram na reserva de Dourados porque lá não tem mais remédio. Sua filha mais velha também sabe bastante do conhecimento das ervas, pois, ela a ensina.
} 
terra. Os indígenas que vivem deste lado são guardiões e, por isso, sofrem mais diretamente as pressões de fazendeiros e colonos.

São longos e incertos os anos que transcorrem entre a identificação e delimitação de uma terra indígena e a sua total regularização. No caso de Jatayvary, já se vão dez anos, sem que haja uma solução definitiva. Os passivos ambientais do modelo de uso e ocupação do solo, ao longo de décadas, são somados aos intermitentes processos destrutivos que se seguem. A herança virá através de uma terra arrasada, cujos desafios para a recuperação serão enormes.

$\mathrm{E}$, ao que tudo indica, nem os limites mínimos estabelecidos para a proteção de áreas de preservação permanente, como nascentes e matas ciliares ao longo de rios e córregos e, das áreas de reserva legal estão sendo obedecidos. Na região, a fiscalização ambiental é precária, ampliando-se, assim, o risco de perder o que resta da vegetação. Fato que já havia sido observado, por ocasião do Relatório de Identificação e Delimitação, de 2005:

\begin{abstract}
durante os trabalhos de campo observou-se que os fazendeiros continuam desmatando o pouco que existe das reservas legais e das áreas de preservação permanente. Esta situação poderá tornar-se mais grave se os fazendeiros virem ameaçadas suas propriedades pelo procedimento de identificação e demarcação. Caso isto ocorra, será perdida grande parte da vegetação das áreas remanescentes do cerrado, o que refletirá na diminuição da fauna e da água. Esses remanescentes são de suma importância para a sobrevivência dos índios. Portanto seria aconselhável uma atitude dos órgãos oficiais responsáveis (FUNAI, IBAMA) restringindo o uso da área identificada para a proteção ambiental até a regularização da terra como indígena (THOMAZ DE ALMEIDA, 2005, p.89).
\end{abstract}

As medidas protetivas territoriais devem impedir o avanço de mais processos destrutivos e ao mesmo tempo conservar/cuidar/recuperar a terra. Um plano de recuperação ambiental foi formulado em recente trabalho realizado pelo Imad (2015, p. 82-4), intitulado "Diagnóstico Socioambiental Participativo de Terras Indígenas Kaiowá-Ñandéva visando seu etnodesenvolvimento - ETNOECO," onde foram propostas as seguintes medidas para Jatayvary, que aguardam financiamento:

as intervenções ambientais envolvem a recomposição de áreas de mata ciliar ao longo do Córrego Jata'yvary, no limite norte da TI, uma faixa de proteção de mata nativa ao longo das divisas oeste e sul, como apontado no diagnóstico, e um curto corredor ecológico para interligar a mata ciliar do córrego com um remanescente florestal. Recomenda-se também a implantação de aceiro para combater o rápido alastramento de incêndios, devido à grande quantidade de capim seco. Uma medida imediata e prioritária para mitigar e prevenir graves intoxicações é dotar a TI Jata'yvary de um cinturão-tampão periférico de mata nativa, de pelo menos $100 \mathrm{~m}$ de largura, ao longo do seu limite oeste, impactado diretamente pelas lavouras de cana-de-açúcar e o uso frequente e intenso de agrotóxicos. Enquanto, no limite sul, outro cinturão-tampão parar proteção do trafego de veículos na BR 463. Estas matas poderão também providenciar alimentos alternativos a formigas e cupins, mitigando seu impacto nas roças, árvores frutíferas e hortas cultivadas pelos moradores. 
A ideia de "projetinho", conforme expressão utilizada pela liderança e também presente na fala do professor se apresenta como uma possibilidade de transformação das realidades. Os inúmeros relatos da falta de apoio para lidar com as adversidades em que vivem revelam que a presença de aliados para realizar parcerias no campo da agricultura e da recuperação ambiental traria oportunidades de geração de renda.

A revitalização da terra está intimamente relacionada às tradições. Ao perguntar a liderança sobre a realização de alguma festa ou cerimônia coletiva em Jatayvary, ele respondeu que não faziam, mas logo lembrou que estava próxima a data em que faria dezesseis anos da retomada e que eles gostariam de fazer uma festa. Aí todos falando em guarani começaram a organizar um almoço para o dia seguinte, em que eu deveria levar o puchero e os refrigerantes. Para retribuir a boa acolhida que todos me deram, concordei com a proposta de confraternizar e encerrar esse ciclo do meu trabalho de campo com o almoço coletivo no "lugar de jatobá" e de "guavira" cuja "terra está pela força da comunidade". 


\section{CONSIDERAÇÕES FINAIS}

São muitos os caminhos das percepções, são muitos os territórios ambientais e são muitos os kaiowá-guarani. São plurais e são únicos. Assim como foram as minhas percepções sobre as suas percepções com a territorialidade. Percepções que foram além do pensamento racional e transitaram por aspectos fenomenológicos de sentidos e sentimentos. Os limites do que são as minhas percepções e do que são as percepções deles nem sempre estão claros. Contudo, procurei trazer para o texto as suas falas literais para que suas vozes pudessem ser depreendidas do conjunto das minhas análises.

Eles não são sujeitos de uma dada etnia analisados de uma forma genérica. São sujeitos que embora pertençam a um grupo étnico, social, econômico, cultural, geracional e de gênero têm suas percepções individualizadas. Busquei ao longo do trabalho de campo, escutar muito mais do que falar. As longas falas sobre seu modo de vida, suas dificuldades, as violências sofridas, sua cosmovisão sobre a terra revelam algumas pistas sobre suas percepções. Foram estimuladas caminhadas como prácticas de conversação livre através da indicação de alguns temas que serviram de roteiro para os diálogos.

As percepções são importantes para a compreensão dos fluxos de vida e para a dinâmica dos territórios. Podem, inclusive, auxiliar na construção de políticas públicas que levem em consideração a diversidade de saberes e a autonomia dos povos. Para além dos encaminhamentos pragmáticos, desvendar percepções da terra e de sua gente revela toda uma riqueza e sabedoria que foi e continua sendo, em grande medida, subjugada pela prevalência de pensamentos e ações monoculturais.

As situações fundiárias no sul de MS revelam uma gama de transformações ambientais com profundas implicações nos sistemas sociais e econômicos dos kaiowáguarani. Seria necessário perceber e respeitar as multidimensões e a diversidade das experiências com a terra, permitindo, assim, a coexistência de diversos modos de vida. Modos estes que o Estado e os modelos econômicos hegemônicos de várias formas não permitiram que coexistissem através dos processos de colonização. Isto levou a uma redução das experiências plurais em termos de diversidade biológica e cultural.

Refleti sobre o que se poderia chamar de teoria da destruição ambiental em decorrência das heranças coloniais. Foram muitos os processos destrutivos das terras indígenas no sul de MS, que respeitadas as peculiaridades, existem muitos pontos em comum para as três terras indígenas analisadas.

As racionalidades econômicas adotadas desde o monopólio da Companhia Matte Larangeira, passando pela CAND, fazendas, latifúndios e monoculturas afetaram profundamente as terras tradicionais e os kaiowá-guarani. De um modo geral ocorreu o seguinte movimento de destruição dos ecossistemas: desmatamento, fazenda de gado com 
introdução da braquiária; fogo para combater a braquiária e fazer roça e desmatamento ampliado.

Foram observadas algumas regularidades nas três terras estudadas: desmatamento; introdução de espécies invasoras como braquiária e colonião; desequilíbrio ambiental com superpopulação de formigas, de cupins e de outras pragas; solos degradados; rios e córregos assoreados; redução/extinção de espécies; poluição de corpos hídricos; uso de agrotóxico e outros defensivos químicos; dependência de insumos, como trator e outros na prática da agricultura; arrendamento de terras para uso de práticas de agricultura das fazendas do entorno e ampliação do consumo com geração de resíduos difíceis de serem absorvidos pela terra.

Especificamente, para a reserva (Te'ýkue), modelo implantado a partir de 1915, as diversas heranças coloniais se sucederam com muita força, dentre as quais: o ajuntamento de várias famílias extensas; os conflitos internos em decorrência de novas ordens sociais no espaço reservado; o paulatino adensamento demográfico; o esgotamento de condições ambientais adequadas ao modo de vida e o fracasso de muitas experiências de projetos econômicos de agricultura impostos e implementados.

Para a terra indígena regularizada, a herança do passivo ambiental de fazendas agropecuárias deixou várias marcas, como: desmatamento; introdução de espécies exóticas (braquiária e colonião); perda de espécies da fauna e da flora; contaminação por agrotóxicos; cansaço e baixa fertilidade do solo; assoreamento de córregos e rios; pragas; infestação de formigas e cupins. O rastro de destruição teve sua marca ampliada, como se pode observar no caso de Sucurui'y entre a identificação e delimitação e a posse definitiva da terra. As longas pendências judiciais que envolveram a regularização definitiva favoreceram a degradação ambiental. Nesta situação, não só os tekohas são demarcados como ilhas, mas também os fragmentos de mato também ficam ilhados.

Para a terra indígena não regularizada, o legado dos passivos ambientais descritos acima ainda segue operando, além de uma inexistente ou baixa oferta de serviços, como educação, saúde, acesso à água e energia e, dos conflitos decorrentes dos projetos agropecuários presentes na terra já identificada e delimitada. Jatayvary sofre com a herança do passado que além de se refletir no presente, compromete ao que tudo indica, seriamente, o seu futuro. É uma triste metáfora a herança do futuro que se prolonga com o contínuo avanço dos problemas gerais identificados mais a constante ameaça das atividades do setor sucroalcooleiro e de colonos que ocupam suas terras tradicionais. $A$ gente de Jatayvary aguarda a regularização definitiva enquanto avançam os processos de destruição. Por isso, o reconhecimento dos direitos das populações indígenas sobre seus 
territórios, mesmo que em processo de demarcação é imprescindível, inclusive, para frear o avanço da devastação ambiental.

A perda de biodiversidade também é uma perda para a sociodiversidade, com consequências para a cultura e a espiritualidade, cujos reflexos podem ser sentidos na alimentação, nos rituais, nos espaços de caça e pesca, na agricultura e no rompimento ou esfacelamento dos saberes entre uma geração e outra.

As histórias de destruição estão muito presentes na vida das terras indígenas. As explicações para este fenômeno, principalmente, por parte dos rezadores e pessoas mais idosas, passam pelas interpretações cosmológicas, pela falta de reza e pela não prática das tradições do modo de ser. As soluções e reversões desse quadro além de passarem pela cosmologia cada vez mais passam pela compreensão de que os conhecimentos técnicocientíficos dos brancos auxiliam nesse processo de recuperação do mato e de retorno dos bichos.

Problemas que foram introduzidos por sistemas alheios passariam por respostas também alheias, mas com uma conjugação de elementos que precisariam ser trabalhados em uma perspectiva de intensa integração intercultural na formulação e execução de medidas que visem à recuperação e repovoamento da terra com os seres que a habitavam no passado. Através de várias falas dos meus interlocutores emergiram ideias de como resolver alguns problemas relacionados à degradação da terra, de como controlar ou acabar com a braquiária, por exemplo. Soluções com base no conhecimento próprio e em experimentações que se coadunam com algumas soluções técnico-científicas. A resistência da terra e da gente da terra aponta para uma incrível capacidade de reinvenção, indicando caminhos a partir de experiências construídas dialogicamente.

Entendo que a construção de soluções para "problemas ambientais" passa pelo diálogo de saberes indígenas e de saberes não-indígenas para que juntos possam apontar caminhos para as questões introduzidas pelas heranças coloniais nos espaços de ocupação tradicional e nas áreas demarcadas. O diálogo de saberes na diversidade da vida revela a importância da interculturalidade para a construção de uma sustentabilidade voltada para a recomposição da vida e para a minoração de processos de colonização que resultaram em profundas transformações culturais e ambientais. Um dos inúmeros desafios para se alcançar a sustentabilidade em bases interculturais seria harmonizar os conhecimentos étnicos com conhecimentos não indígenas paras as práticas de recuperação da terra e de manejo ambiental.

De uma teoria da destruição para uma teoria da restauração, da revitalização, do repovoamento da terra com diversidade, os kaiowá-guarani têm muito a ensinar na construção de uma sustentabilidade baseada na simples e profunda noção de pertencer. Contribuições, estas, que incorporam uma dimensão espiritual na formulação de uma 
sustentabilidade da e pela vida que passa pelo pertencimento da sociedade a um dado território para estimular e promover mudanças. O que implica em viver a sustentabilidade na diversidade de saberes, dialogando sobre a construção de consensos para intervenções práticas que digam respeito aos usos naturais e culturais de uma determinada terra e gente.

O pertencer à terra perpassa a memória dos antepassados e memória da terra e dialoga com a espiritualidade, onde a terra é vista como unidade. A identidade territorial e cultural está relacionada com suas memórias individuais e coletivas; as atribuições dos nomes dos lugares a que se referem; a alimentação; as plantas e os animais sagrados; sua agricultura; seus rituais e a reverência à natureza. A emblemática frase: "a gente que pertence à terra e não a terra que nos pertence", revela também, na situação atual do kaiowá-guarani, que o pertencimento perpassa o processo de luta das terras tradicionais.

As práticas desenvolvidas pelos kaiowá-guarani históricos pareciam ser dotadas do que enquadraríamos como sustentáveis: disposição geográfica das famílias com pequenos núcleos de adensamento populacional; economia da reciprocidade; baixo consumo; consumo para o imediato, com baixa acumulação de coisas; agricultura de coivara; respeito à recuperação do solo, com o repouso dos cultivares; reverência aos seres/donos da natureza: bichos e plantas, através de rezas; diversos conhecimentos dos ciclos da terra e dos seus elementos com uma visão de integralidade e interdependência da terra.

A prática do oguatá (caminhar ou peregrinar) no território devido a diversas causas que vão desde desentendimentos internos, acusações de feitiço, doenças ou mortes de parentes ao desgaste da terra e dificuldades de subsistência pode ser entendida como um comportamento positivo do ponto de vista ambiental. Antes da chegada das frentes econômicas a prática poderia ser realizada, hoje, porém, devido ao quadro de situações fundiárias e devastação ambiental se tornou algo praticamente inviável.

As condições socioeconômicas e ambientais mudaram muito no decorrer de mais de um século de colonização, mas mesmo com as transformações provocadas por estes processos, há uma memória coletiva do que foi e do que de certa forma continua sendo a terra. Há um pertencimento e uma localização desse modo de vida. A forte tradição da oralidade kaiowá-guarani traz uma contribuição mística da palavra. Uma concepção de mundo no sentido de amor a terra, de viver na natureza e com a natureza, de viver no mato e com o mato.

As práticas ditas sustentáveis também se transformaram. Mas são nessas terras, onde, com toda a herança de diversos processos de destruição do meio ambiente, ainda se encontra pulsante uma gama de conhecimentos sobre uma natureza que não foi esquecida e que pode ser recuperada, não na sua originalidade, mas através de espécies que podem 
repovoar esse ambiente com a ajuda dos jara, das rezas e de conhecimentos que captem a riqueza da cultura kaiowá-guarani.

A ideia de pertencer à terra, vivenciada pelo kaiowá-guarani, revela uma importante contribuição a "ciência da sustentabilidade". Isto porque, podem ser ricas as interações interdisciplinares entre saberes científicos e saberes tradicionais no campo da sustentabilidade, pois, podem operar de modo dialógico ao se pensar e propor soluções para problemas complexos cuja origem vem de processos colonizadores. Além disso, o foco da sustentabilidade pode se deslocar da ideia de gestão ou gerenciamento ambiental e territorial para novos modelos de ser e estar na terra. Pertencendo à terra e convivendo na, pela e com a terra, bem como com todas as suas espécies.

A sabedoria kaiowá-guarani revela que a gente que pertence à terra e não a terra que nos pertence. Isto revela uma lógica diferente de se relacionar com a terra, bem distante de racionalidades guiadas por processos de apropriação, de dominação e de destruição. Pertencer é amar, é envolver-se, é sentir-se parte de. É um elemento propulsionador para a construção de realidades integrativas entre natureza e sociedade. Existe a percepção da terra como um ser vivo que tem corpo, alma e palavra. E são as doces palavras e atitudes que se equilibram com essa terra. O conhecimento dos mais velhos, dos mestres tradicionais e dos guardiões da natureza reforça esse modo de pertencer.

Sustentabilidade com pertencimento implica em abandonar discursos economicistas, burocratizados e dominadores. E, também, em abdicar conceitos apropriados por diversos setores econômicos que enxergam a sustentabilidade como uma tendência de mercado, como algo bom para o marketing das suas empresas, podendo agregar valor aos seus produtos.

A cultura da terra dos kaiowá-guarani tem muito a contribuir para a construção de uma "sustentabilidade" regional. Suas bases culturais do uso da terra, a partir de uma visão de mundo/cosmologia endógena, genuína, diversificada, com inserção de saberes locais, de gente que mexe com a terra poderia vitalizar o assim, o degastado, banalizado, vazio, institucionalizado e normatizado "slogan" do desenvolvimento sustentável.

A ideia de sustentabilidade da e pela vida (pelo modo de ser e conviver com e na natureza) está ligada aos sentimentos e ao conhecimento ligado a terra para e por uma vida melhor. Uma vida mais amorosa. Para algo que alimente a alma com base em comportamentos que estejam calcados em uma ética do respeito e do cuidado com a terra. Nesta perspectiva, o ser humano deve ser colocado em um lugar que se comporte como mais uma das espécies do planeta. Onde a sua suposta superioridade humana seja trabalhada em favor de modos de vida diversos: humanos e não-humanos. Possibilitando, assim, um compartilhamento e expansão com as demais formas de vida. A sustentabilidade e diversidade da vida do modelo kaiowá-guarani de proteção da terra traz consigo a 
dimensão do sagrado, da reverência, do respeito aos ciclos de vida e de recuperação da natureza, do pertencimento e da ligação com a terra, que passa pelos seres que a habitam.

Diante das situações coloniais descritas, parece necessário pensar em transformar paisagens monoculturais em paisagens com diversidade de mato, como foram assim um dia. O modelo de educação escolar indígena de Te ýikue, baseado em diálogo de saberes entre rezadores, idosos, professores, alunos e suas famílias aproximando gerações; o Projeto Kaiowá-Guarani de recuperação ambiental; a adoção de sistemas agroecológicos na unidade experimental de Téýikue; a demanda por casas de rezas e por uma educação diferenciada e de qualidade parecem oferecer pistas para o futuro e apontar caminhos.

Face às realidades apresentadas, a conservação ambiental passa pela proteção das ilhas e fragmentos de florestas, plantas e de outras espécies nativas ainda existentes nas terras indígenas e no seu entorno. Pesam muitas dificuldades para serem mantidos os fragmentos de mata devido a diversas ameaças internas e externas. Muitas destas espécies se encontram em APP's e reservas legais em fazendas, cujo cumprimento da normativa e fiscalização ambiental são frágeis. Soa necessário integrar florestas nativas e replantadas dentro e fora das terras indígenas, por exemplo, através da criação de zonas de amortecimento e corredores ecológicos.

É importante pensar modelos de recuperação ambiental para as terras indígenas com projetos a partir da comunidade, com formas mais inovadoras de condução e de financiamento, como, por exemplo, via financiamento coletivo para um dado projeto (crowdfunding) ou por serviços e produtos gerados internamente como alimentos orgânicos, sementes crioulas e mudas nativas. Isto a partir de contextos de sistemas agroflorestais para se pensar em novas economias alternativas voltadas para o reflorestamento e a recuperação ambiental.

Outro aspecto importante a ser pensado é o envolvimento da população urbana da região, geralmente identificada como racista e preconceituosa, mas que também congrega vários tipos de "gente", inclusive gente que apoia a diversidade da vida. Por isso, a valorização e o envolvimento dos moradores urbanos em projetos de recuperação ambiental em terras indígenas podem despertar sentimentos de pertença e de convivialidade.

A educação escolar indígena também pode contribuir para a educação não-indígena. Aspectos importantes como: o envolvimento das famílias e da comunidade em projetos educacionais; a figura do professor-pesquisador com práticas docentes pautadas na pesquisa da cultura étnica e local; a elaboração de materiais didáticos com base na realidade vivida e não a simples adoção de materiais homogeneizadores indicam o quanto temos que aprender com eles.

O modelo de "alfabetização ecológica" ou "educação ambiental" de Te'ýikue sinaliza caminhos para repensar modelos vivenciados nas famílias e nas escolas de não-índios. O 
que revela como esta temática pouco avançou em termos de práticas e hábitos cotidianos na sociedade não-indígena, visto que os processos de degradação ambiental e as pressões por recursos naturais e de consumo só ampliaram as contradições do modelo de desenvolvimento que vivemos.

As transformações ambientais profundas nas paisagens e no uso dos recursos naturais ocorridas nos territórios de ocupação tradicional dos kaiowá-guarani têm gerado novas interpretações e ressignificações na relação sociedade-natureza. O modelo de desenvolvimento implementado na região, que abrange as áreas de estudo, vem impondo o seu modelo sobre os territórios tradicionais. A monocultura de plantios e de racionalidade é uma violência contra a diversidade da terra e contra os povos igualmente diversos que a habitam.

A partir da destruição das matas (em diversas fases dos processos de colonização com as frentes econômicas) que causou e vem causando significativos impactos na organização social e, consequentemente, no modo de ser kaiowá-guarani, o sentimento de pertencimento é um forte elemento de resistência à terra, na terra e pela terra.

A resistência à destruição da terra e dos saberes da terra possui duas faces: a) resistência através da diversidade natural, através do que foi verificado na pesquisa empírica, por exemplo, pelas plantas medicinais escondidas embaixo do colonião ou da braquiária em todas as terras indígenas; do guaviral nativo em Jatayvary e da onça que passeia na mata de Sucurui'y; b) resistir através da diversidade cultural, como pela via dos diálogos entre rezadores e escola; das demandas pela construção de casas de reza; pela continuidade de rituais; pelo conhecimento das plantas e procedimentos de cura e pelos modelos de recuperação ambiental.

Mesmo com todas as adversidades, a terra (natureza, planeta) e os saberes (modos de ser kaiowá) resistem. Por isso o direito à terra (esta, entendida como um ser vivo e com dinâmicas próprias, cuja compreensão deve ir além da dicotomia entre antropocentrismo e biocentrismo) e o direito ao território (entendido com um viés étnico e de ocupação tradicional) devem ser respeitados. 


\section{REFERÊNCIAS}

ABRAM, David. Um mundo além do humano. Espaço Ameríndio, Porto Alegre, v. 7, p. 6495, jul/dez. 2013.

AFONSO DA SILVA. José. Demarcação de terra indígena. Revista Interesse Público, Belo Horizonte, a. 10, n. 52, nov/dez 2008.

AZANHA, Gilberto. Sustentabilidade nas sociedades indígenas brasileiras. Tellus, Campo Grande/MS, a. 5, n. 8/9, p. 11-28, abr./out. 2005.

BARBIERI, José Carlos. Desenvolvimento e meio ambiente: as estratégias de mudanças da Agenda 21. 3. ed. Petrópolis: Vozes, 2000.

BARBOSA DA SILVA, Alexandra. Entre a aldeia, a fazenda e a cidade: ocupação e uso do território entre os Guarani de Mato Grosso do Sul. Tellus, Campo Grande/MS, a. 9, n. 16, p. 81-104, jan./jun. 2009.

BARRETO FILHO, Henyo Trindade. Os predicados do desenvolvimento e a noção de autoctonia. Tellus, Campo Grande/MS, a. 6, n. 10, p. 11-21, abril 2006.

BARTH, Fredrik. Grupos étnicos e suas fronteiras. In: POUTIGNAT, Philippe, STREIFFFENART, Jocelyne. Teorias da etnicidade. São Paulo: Unesp, 2011.

BARTOLOMÉ, Miguel Alberto. Chamanismo y religion entre los Ava-Katu-Ete. Asunción: Biblioteca Paraguaya de Antropologia, Centro de Estudios Antropológicos, Universidad Católica, 1991.

BATALLA, Guillermo Bonfil. El concepto de indio en América: una categoría de la situación colonial. Annales de Antropología, México, 1970.

BATISTA, Teresinha Aparecida da Silva. A luta por uma escola indígena em Te'ýikue, Caarapó/MS. 2005. Dissertação (Mestrado em Educação) - Universidade Católica Dom Bosco, Campo Grande.

BENITES, Eliel. Oguata Pyahu (uma nova caminhada) no processo de desconstrução e construção da educação escolar indígena na reserva indígena Te'ýikue. 2014. Dissertação (Mestrado em Educação) - Universidade Católica Dom Bosco, Campo Grande.

BENITES, Tonico. A escola indígena na ótica dos Ava Kaiowá: impactos e interpretações indígenas. 2009. Dissertação (Mestrado em Antropologia Social) - Museu Nacional, UFRJ, Rio de Janeiro.

Rojeroky hina ha roike jevy tekohape (Rezando e lutando): o movimento histórico do Aty Guasu dos Ava Kaiowa e dos Ava Guarani pela recuperação de seus tekoha. 2013. Tese (Doutorado em Antropologia Social) - Museu Nacional, UFRJ, Rio de Janeiro.

BOFF, Leonardo. Ecologia grito da terra, grito dos pobres. São Paulo: Ática, 1999a.

Ecologia, mundialização, espiritualidade: a emergência de um novo paradigma. 3. ed. São Paulo: Ática, 1999b.

O cuidado necessário: na vida, na saúde, na educação, na ecologia, na ética e na espiritualidade. Petrópolis: Vozes: 2012a. 
$\overline{2012 b}$.

Saber cuidar: ética do humano, compaixão pela terra. 18. ed. Petrópolis: Vozes:

Sustentabilidade: o que é - o que não é. Petrópolis: Vozes: 2012c.

BERGER, Peter L., LUCKMANN, Thomas. A construção social da realidade. 35. ed. Petrópolis: Vozes, 2013.

BRAND, Antonio Jacó. O confinamento e o seu impacto sobre os Pãi/Kaiowa. 1993. Dissertação (Mestrado em História) - PUCRS, Porto Alegre.

O impacto da perda de terra sobre a tradição Kaiowa/Guarani: os difíceis caminhos da palavra. 1997. Tese (Doutorado em História) - PUC, Rio Grande do Sul.

Os Kaiowá/Guarani no Mato Grosso do sul e o processo de confinamento - a "entrada de nossos contrários". In: CIMI, Comissão Pró-índio de SP, Procuradoria Regional da República da $3^{\mathrm{a}}$ Região (orgs.). Conflitos de Direitos sobre as Terras Guarani Kaiowá no Estado do Mato Grosso do Sul. São Paulo: Palas Athena, 2001.

. Os complexos caminhos da luta pela terra entre os kaiowá e guarani no MS. Tellus, Campo Grande/MS, a. 4, n. 6, p. 137-150, abr. 2004.

BURSZTYN, Marcel, FERRAZ DA FONSECA, Igor. Mercadores de moralidade: a retórica ambientalista e a prática do desenvolvimento sustentável. Ambiente \& Sociedade, Campinas/SP, v. X, n. 2, p. 169-186, jul.-dez. 2007.

BURSZTYN, Marcel, BURSZTYN, Maria Augusta. Fundamentos de política e gestão ambiental: os caminhos do desenvolvimento sustentável. Rio de Janeiro: Garamond, 2012.

CARDOSO DE OLIVEIRA, Roberto. A sociologia do Brasil indígena. Brasília: Unb, Rio de Janeiro: Tempo Brasileiro, 1978.

CARIAGA. Diógenes Egídio. As transformações no modo de ser criança entre os kaiowá em Te'ýikue (1950 - 2010). 2012. Dissertação (Mestrado em História) - Faculdade de Ciências Humanas, Universidade Federal da Grande Dourados, Mato Grosso do Sul.

CARNEIRO DA CUNHA, Manuela. Cultura com aspas e outros ensaios. São Paulo: Cosac Naify, 2009.

CASANOVA, Pablo González. Colonialismo interno (uma redefinição). In: BORON, Atílio A.; AMADEO, Javier; GONZÁLEZ, Sabrina. A teoria marxista hoje: problemas e perspectivas. São Paulo: CLACSO, 2007.

CASTRO, Edna F. Território, biodiversidade e saberes de populações tradicionais. In: DIEGUES, Antonio Carlos (org). Etnoconservação: novos rumos para a proteção da natureza nos trópicos. 2. ed. São Paulo: Annablume, Nupaub-USP, Hucitec, 2000.

CASTRO, Edna F. "Nesse tempo não existia essas ilhas por ali": sobre modos de perceber o ambiente e narrar o passado. Iluminuras, Porto Alegre, v. 14, n. 34, p. 11-32, ago./dez. 2013.

CAVALCANTE, Thiago Leandro Vieira. Colonialismo, território e territorialidade: a luta pela terra dos Guarani e Kaiowa em Mato Grosso do Sul. 2013. Tese (Doutorado) - UNESP, Assis/SP. 
CÉSAR, Constança Marcondes. Implicações contemporâneas do mito. In: MORAIS, Régis de (org.). As razões do mito. Campinas: Papirus, 1988.

CERBONE, David R. Fenomenologia. 2. ed. Petrópolis: Vozes, 2013.

CHAMORRO, Graciela. Terra Madura Yvy Araguyje: fundamento da palavra guarani. Dourados: UFGD, 2008.

Decir el cuerpo: historia y etnografia del cuerpo en los pueblos Guaraní. Tomo I. Asunción: Tiempo de Historia, FONDEC, 2009.

História Kaiowá. São Bernardo do Campo: Nhanduti, 2015.

CLASTRES, Hélène. Terra sem mal. Corumbiara: Tapé, 2007.

COUTINHO JR, Walter. Relatório sobre a identificação e delimitação da Terra Indígena Sucuri'y. Brasília: FUNAI, 1995.

DALY, Herman E. Crescimento sustentável? Não, obrigado. Ambiente \& Sociedade, Campinas/SP, v. VII, n. 2, p. 197-201, jul.-dez. 2004.

DARDEL, Eric. O homem e a terra: natureza da realidade geográfica. São Paulo: Perspectiva, 2015.

DEAN, Warren. A ferro e a fogo: a história e a devastação da mata atlântica brasileira. São Paulo: Companhia das Letras, 1996.

DESCOLA, Philippe. Ecologia e Cosmologia. In: DIEGUES, Antonio Carlos (org). Etnoconservação: novos rumos para a proteção da natureza nos trópicos. 2. ed. São Paulo: Annablume, Nupaub-USP, Hucitec, 2000.

Construyendo naturalezas, ecologia simbólica y práctica social. In: DESCOLA, Philippe, PÁLSSON, Gísli (coord.). Naturaleza y sociedade: perspectivas antropológicas. México, DF: Siglo Veintiuno, 2001.

Más allá de la naturaleza y de la cultura. In: MARTíNEZ, Leonardo Montenegro (ed.). Cultura y Naturaleza. Bogotá: Jardín Botánico de Bogotá, José Celestino Mutis, 2011.

DESCOLA, Philippe, PÁLSSON, Gísli. Introducción. In: DESCOLA, Philippe, PÁLSSON, Gísli (coord.). Naturaleza y sociedade: perspectivas antropológicas. México, DF: Siglo Veintiuno, 2001.

DÍAZ-POLANCO, Héctor. La rebelión zapatista y la autonomia. México, DF: Siglo Veintiuno, 2011a.

Autonomía regional: la autodeterminación de los pueblos índios. 4. ed. México, DF: Siglo Veintiuno, 2011b.

DIEGUES, Antonio Carlos. Etnoconservação da natureza: enfoques alternativos. In: DIEGUES, Antonio Carlos (org). Etnoconservação: novos rumos para a proteção da natureza nos trópicos. 2. ed. São Paulo: Annablume, Nupaub-USP, Hucitec, 2000.

DRUMMOND, José Augusto. Por que estudar a história ambiental do Brasil? Ensaio temático. Varia História, Rio de Janeiro, n. 26, p. 13-32, 2002. 
Proteção e produção: biodiversidade e agricultura no Brasil. Rio de Janeiro: Garamond, 2014.

ELALI, Gleice Azambuja, FEIJÓ DE MEDEIROS, Samia Thaís. Apego ao lugar (vínculo com o lugar - place attachment). In: CAVALCANTE, Sylvia, ELALI, Gleice A. (orgs.). Temas básicos em Psicologia Ambiental. Petrópolis: Vozes, 2011.

ELIADE, Mircea. Mito e realidade. 4. ed. São Paulo: Perspectiva, 1994.

ESAT - GT. In: PEREIRA, Joelson, COMAR, Vito, MACEDO, Gabriela Zacarias (orgs). Atlas socioambiental do território da Grande Dourados. Dourados: UFGD, 2012.

ESCOBAR, Arturo. Biodiversidad, naturaleza y cultura: localidad y globalidad en las estrategias de conservación. Centro de Investigaciones Interdisciplinarias en Ciencias y Humanidades. Coordinación de Humanidades. México, DF: UNAM, 1997.

El final del salvaje: naturaleza, cultura y política en la antropologia contemporânea. Santa Fé de Bogotá: CEREC, 1999.

O lugar da natureza e a natureza do lugar: globalização ou pós-desenvolvimento? In: LANDER, Edgardo (org.). A colonialidade do saber: eurocentrismo e ciências sociais. Perspectivas latino-americanas. Buenos Aires: Colección Sur Sur, CLACSO, 2005.

. Epistemologías de la naturaleza y colonialidad de la naturaleza. Variedades de realismo y constructivismo. In: MARTíNEZ, Leonardo Montenegro (ed.). Cultura y Naturaleza. Bogotá: Jardín Botánico de Bogotá, José Celestino Mutis, 2011.

FAJARDO, Raquel Z. Yrigoyen. Aos 20 anos do Convênio 169 da OIT: balanço e desafios da implementação dos direitos dos povos indígenas na América Latina. In: VERDUM, Ricardo (org.). Constituições e reformas políticas na América Latina. Brasília: INESC, 2009.

FIAN INTERNACIONAL. Os agrocombustíveis no Brasil: informe da missão de investigação sobre os impactos das políticas públicas de incentivo aos agrocombustíveis sobre o desfrute dos direitos humanos à alimentação, ao trabalho e ao meio ambiente, das comunidades campesinas e indígenas e dos trabalhadores rurais no Brasil. 2008. Disponível em: <<http:www.fian.org>>. Acesso em: 30 jul 2014.

FOLADORI, Guillermo, TAKS, Javier. Um olhar antropológico sobre a questão ambiental. Mana, Rio de Janeiro, v.10, n. 2, p. 323-348, 2004.

FOSTER, John Bellamy. A ecologia de Marx: materialismo e natureza. 3. ed. Rio de Janeiro: Civilização Brasileira, 2011.

FREIRE, Paulo. Pedagogia da esperança: um reencontro com a pedagogia do oprimido. 3. ed. Rio de Janeiro: Paz e Terra, 1992.

GALLOIS, Dominique Tilkin. Cultura "indígena" e sustentabilidade: alguns desafios. Tellus, Campo Grande/MS, a. 5, n. 8/9, p. 29-36, abr./out. 2005.

GALVÃO, Eduardo. Diários de Campo de Eduardo Galvão: entre os Tenetehara, Kaioá e índios do Xingu. Rio de Janeiro: UFRJ, Museu do Índio, Funai, 1996. 
GUARANI HÁ KAIOWÁ, Mbo'ehárakuéra, TEKOHA RA'ANGA KUATIA ÑE'EME. Dourados: Ára Verá/SED/MS, MEC, 2011.

GUDYNAS, Eduardo. Los derechos de la Naturaleza em serio. In: ACOSTA, Alberto, MARTÍNEZ, Esperanza (comp.). La naturaleza con derechos: de la filosofía a la política. Quito: Abya-Yala, 2011.

HADOT, Pierre. O véu de Ísis: ensaio sobre a história da ideia de natureza. São Paulo: Loyola, 2006.

HANNIGAN, John. Sociologia ambiental. Petrópolis: Vozes, 2009.

HEFFES, Gisela. Políticas de la destrucción/Poéticas de la preservación: apuntes para uma lectura (eco)crítica del médio ambiente em América Latina. Rosario: Beatriz Viterbo, 2013.

IBGE. Os indígenas no censo demográfico 2010: primeiras considerações com base no quesito cor ou raça. Disponível em: <<www.ibge.gov.br/indigenas/indigena_censo2010.pdf>>. Acesso em: 28 jun 2013.

IMAD. Diagnóstico Socioambiental Participativo de Terras Indígenas Kaiowá-Ñandéva visando seu etnodesenvolvimento - ETNOECO. Dourados: IMAD, 2015.

INGOLD, Tim. The perception of the environment: essays in livelihood, dwelling and skill. London, New York: Routledge, 2000.

Being alive: essays on movement, knowledge and description. London, New York: Routledge, 2011a.

Consideraciones de un antropólogo sobre la biología. In: MARTíNEZ, Leonardo Montenegro (ed.). Cultura y Naturaleza. Bogotá: Jardín Botánico de Bogotá, José Celestino Mutis, 2011b.

JUNGES, José Roque. (Bio) ética ambiental. São Leopoldo: Unisinos, 2010.

LATOUCHE, Serge. Pequeno tratado do decrescimento sereno. São Paulo: Martins Fontes, 2009.

LAZOS, Elena, PARÉ, Luisa. Miradas indígenas sobre uma naturaleza entristecida: percepciones del deterioro ambiental entre nahuas del sur de Veracruz. México, DF: IIS/UNAM, Plaza y Valdés, 2005.

LEFF, Enrique. Ecología y Capital: racionalidade ambiental, democracia participativa y desarrollo sustentable. México, DF: Siglo Veintiuno, 1994.

Racionalidade ambiental: a reapropriação social da natureza. Rio de Janeiro: Civilização Brasileira, 2006.

Complejidad, racionalidad ambiental y dialogo de saberes. In: CASANOVA, Pablo González (org.). Conceptos Fundamentales de Nuestro Tiempo. México: UNAM, IIS, 2007.

Epistemologia Ambiental. 5 ed. São Paulo: Cortez, 2010. 
Aventuras da epistemologia ambiental: da articulação das ciências ao diálogo de saberes. São Paulo: Cortez, 2012.

La apuesta por la vida: imaginación sociológica e imaginarios sociales em los territórios ambientales del sur. México, DF: Siglo Veintiuno, 2014.

LEONARDOS, Othon Henry, COSTA, Renata Oliveira. Dialogando com saberes da terra para a sustentabilidade da vida. In: PENA-VEGA, Alfredo, PINHEIRO DO NASCIMENTO, Elimar, ANTÔNIO DA SILVEIRA, Márcio. Interdisciplinaridade e universidade no século XXI (orgs.). Brasília: Abaré, 2008.

LEONARDOS, Othon Henry, BILIBIO, Marco Aurélio. Desenvolvimento como espelho do humano. Revista Rede de humanização do Desenvolvimento, Brasília/DF, v. 2, p. 16-19, $2012 \mathrm{a}$.

. Encontro do espírito científico com a alma indígena: uma experiência de humanização pós Rio +20. Revista Rede de Humanização do Desenvolvimento, Brasília/DF, v. 2, p. 31-34, 2012b.

LIMA, Antonio Carlos de Souza. Um grande cerco de paz: poder tutelar, indianidade e formação do Estado no Brasil. Petrópolis: vozes, 1995.

Cenários da educação superior de indígenas no Brasil, 2004-2008: as bases e diálogos do Projeto Trilhas de Conhecimento. In: LIMA, Antonio Carlos de Souza, BARROSO, Maria Macedo (orgs). Povos indígenas e universidade no Brasil: contextos e perspectivas, 2004-2008. Rio de Janeiro: E-papers, 2013.

LIMA, Antonio Carlos de Souza, BARROSO, Maria Macedo. A presença indígena na construção de uma educação superior universal, diferenciada e de qualidade. In: LIMA, Antonio Carlos de Souza, BARROSO, Maria Macedo (orgs). Povos indígenas e universidade no Brasil: contextos e perspectivas, 2004-2008. Rio de Janeiro: E-papers, 2013.

LOVELOCK, James E. Gaia: a new look at life on earth. In: NELISSEN, Nico, VAN DER STRAATEN, Jan, KLINKERS, Leon (eds.). Classics in environmental studies: an overview of classic texts in environmental studies. Utrecht: Internacional Books, 1997.

A vingança de gaia. Rio de Janeiro: Intrínseca, 2006.

Gaia: alerta final. Rio de Janeiro: Intrínseca, 2010.

LÖWY, Michael. Ecologia e socialismo. São Paulo: Cortez, 2005.

MACHADO, Carlos José Saldanha. Desenvolvimento sustentável para o antropoceno. Rio de Janeiro: E-papers, 2014.

MARTINEZ DOS SANTOS, Mariany. A percepção indígena em relação aos impactos do plantio de cana-de-açúcar na terra indígena Jatayvary. Relatório de visita técnica. Coordenação regional de Ponta Porã: FUNAI, 2011.

MELIÁ, Bartolomeu, GRÜNBERG, Georg, GRÜNBERG, Friedl. Los Paĩ-Tavyterã: etnografía Guaraní del Paraguay contemporáneo. Asunción: CEADUC, 1976.

MELIÁ, Bartolomeu. Educação indígena e alfabetização. São Paulo: Loyola, 1979. 
- El guaraní conquistado y reducido. Asunción: Biblioteca Paraguaya de Antropologia, 1988.

MERLEAU-PONTY, Maurice. Fenomenologia da percepção. 2. ed. São Paulo: Martins Fontes, 1999.

MIGNOLO, Walter. D. Os esplendores e as misérias da 'ciência': colonialidade, geopolítica do conhecimento e pluri-versalidade epistêmica. In: SANTOS, Boaventura de Sousa (Org.). Conhecimento prudente para uma vida decente: Um discurso sobre as ciências revisitado. São Paulo: Cortez, 2004.

MINISTÉRIO DA JUSTIÇA. Projetos Demonstrativos dos Povos Indígenas - PDPI. Disponível em: <<htpp://portal.mj.gov.br/data/pages/>>. Acesso em: 18 mai 2011.

MONTEIRO, Maria Elizabeth Brêa. Levantamento Histórico sobre os Índios Guarani Kaiwá. Rio de Janeiro: Museu do Índio, 2003.

MORAN, Emilio F. Adaptabilidade humana: uma introdução à Antropologia Ecológica. São Paulo: Edusp, 1994. 2008

Nós e a natureza: uma introdução às relações homem-ambiente. São Paulo: Senac,

Meio ambiente e ciências sociais: interações homem-ambiente e sustentabilidade. São Paulo: Senac, 2011.

MOREIRA DA SILVA, Lásaro. A legitimidade do processo de retomada das terras tradicionais pelos índios Kaiowá e Ñandéva em Mato Grosso do Sul. 2002. Dissertação (Mestrado Interinstitucional em Direito Constitucional) - UNIGRAN/UnB, Brasília.

MOSCOVICI, Serge. Natureza: para pensar a ecologia. Rio de Janeiro: Mauad X, Instituto Gaia, 2007.

MOURÃO, Ada Raquel Teixeira, CAVALCANTE, Sylvia. Identidade de lugar. In: CAVALCANTE, Sylvia, ELALI, Gleice A. (orgs.). Temas básicos em Psicologia Ambiental. Petrópolis: Vozes, 2011.

MURA, Fabio. Por que fracassam os projetos de desenvolvimento entre os Guarani de Mato Grosso do Sul? Notas críticas para uma política de sustentabilidade. Tellus, Campo Grande/MS, a. 5, n. 8/9, p. 53-72, abr./out. 2005.

À procura do "bom viver": território, tradição de conhecimento e ecologia doméstica entre os kaiowá. 2006. Tese (Doutorado em Antropologia Social) - Museu Nacional, UFRJ, Rio de Janeiro.

A trajetória dos chiru na construção da tradição de conhecimento Kaiowa. Mana, Rio de Janeiro, vol. 16-1, p. 123-150, 2010.

NOELLI. Francisco Silva. Sem tekoha não há teko.1993. Dissertação (Mestrado em História) - PUCRS, Porto Alegre.

NOGUERA DE ECHEVERRI, Ana Patrícia. El reencantamiento del mundo. México, DF: PNUMA, 2004. 
OLIVEIRA, Alessandro Roberto de. Processo de construção de Política Nacional de Gestão Ambiental e Territorial de Terras Indígenas - PNGATI: possibilidades, limites e desafios do diálogo entre estado e povos indígenas no Brasil. Brasília: FUNAI, GIZ, 2011.

ONG REPÓRTER BRASIL. Em terras alheias: a produção de soja e cana em áreas no Mato Grosso do Sul. Disponível em: <<http:|lwww.agrocombustiveis.org.br. 2012>>. Acesso em: 02 abr 2014a.

ONG REPÓRTER BRASIL. O Brasil dos agrocombustíveis: impactos das lavouras sobre a terra, o meio e a sociedade - cana 2009. Disponível em: <<http:Ilwww.agrocombustiveis.org.br. 2010>>. Acesso em: 02 abr 2014b.

OST, François. A natureza à margem da lei: a ecologia à prova do Direito. Lisboa: Instituto Piaget, 1995.

OVERING, Joanna. O mito como história: um problema de tempo, realidade e outras questões. Mana, Rio de Janeiro, v. 1, n. 1, p. 107-140, out. 1995.

PACARI, Nina. Naturaleza y território desde la mirada de los pueblos indígenas. In: ACOSTA, Alberto, MARTÍNEZ, Esperanza (comp.). Derechos de la naturaleza: el futuro es ahora. Quito: Abya-Yala, 2009.

PÁDUA, José Augusto. Um sopro de destruição: pensamento político e crítica ambiental no Brasil escravista (1786-1888). Rio de Janeiro: Jorge Zahar, 2002.

Um país e seis biomas: ferramenta conceitual para o desenvolvimento sustentável e a educação ambiental. In: PÁDUA, José Augusto. (org.). Desenvolvimento, justiça e meio ambiente. Belo Horizonte: UFMG, São Paulo: Peirópolis, 2009.

A história ambiental como fronteira interdisciplinar: aspectos teóricos e metodológicos. In: FRANCO, José Luiz de Andrade, DUTRA E SILVA, Sandro, DRUMMOND, José Augusto, TAVARES, Giovana Galvão (Orgs.). História Ambiental: fronteiras, recursos naturais e conservação da natureza. Rio de Janeiro: Garamond, 2012.

PELIZZOLI, Marcelo L. Correntes da ética ambiental. Petrópolis: Vozes, 2002.

PEREIRA, Levi Marques. Parentesco e organização social Kaiowá. 1999. Dissertação (Mestrado) - Universidade Estadual de Campinas/UNICAMP, Campinas/SP.

O movimento étnico-social pela demarcação das terras guarani em MS. Tellus, Campo Grande/MS, a. 3, n. 4, p. 137-145, abr. 2003.

Imagens kaiowá do sistema social e seu entorno. 2004. Tese (Doutorado em Antropologia Social) - Universidade de São Paulo, São Paulo.

Demarcação de terras kaiowa e guarani em MS: ocupação tradicional, reordenamentos organizacionais e gestão territorial. Tellus, Campo Grande/MS, a.10, n. 18, p. 115-137, jan./jun. 2010.

PIMENTEL, Spensy Kimitta. Elementos para uma teoria política Kaiowá e Guarani. 2012. Tese (Doutorado) - Faculdade de Filosofia, Letras e Ciências Humanas, Universidade de São Paulo, São Paulo.

PINHEIRO DO NASCIMENTO, Elimar. Trajetória da sustentabilidade: do ambiental ao social, do social ao econômico. Estudos avançados, São Paulo, v. 26, n. 74, 2012a. 
Sustentabilidade: o campo de disputa de nosso futuro civilizacional. In: LÉNA, Philippe, PINHEIRO DO NASCIMENTO, Elimar (orgs.). Enfrentando os limites do crescimento: sustentabilidade, decrescimento e prosperidade. Rio de Janeiro: Garamond, 2012b.

PNGATI. Construindo a Política Nacional de Gestão Territorial e Ambiental das Terras Indígenas. Documento de apoio para as consultas regionais. Brasil: 2009.

POLANYI, Karl. A grande transformação: as origens da nossa época. 2. ed. Rio de Janeiro: Campus, 2000.

POPOL VUH. Las antiguas historias del Quiché. 2. ed. México: FCE, 1960.

PORTO-GONÇALVES, Carlos Walter. El desafio ambiental. México, DF: PNUMA, 2004.

PRIMACK, Richard B., RODRIGUES, Efraim. Biologia da conservação. Londrina: Planta, 2001.

QUIJANO, Aníbal. "Colonialidad del poder, eurocentrismo y América Latina". En: LANDER, Edgardo (comp.). La colonialidad del saber: eurocentrismo y ciencias sociales. Buenos Aires: Perspectivas Latinoamericanas, CLACSO, Consejo Latinoamericano de Ciencias Sociales, 2000.

REGAN, Tom. The case for animal rights. Berkeley, Los Angeles: University of California Press, 1983.

REZENDE, Astolpho. O Estado de Matto-Grosso e as supostas terras do Barão de Antonina. Rio de Janeiro: S. Monteiro \& Cia Ltda, 1924 apud COUTINHO JR, Walter. Relatório sobre a identificação e delimitação da Terra Indígena Sucuri'y. Brasília: FUNAI, 1995.

SAES, Sílvia Faustino de Assis. Percepção e imaginação. São Paulo: Martins Fontes, 2010.

SACHS, Ignacy. Caminhos para o desenvolvimento sustentável. 3. ed. Rio de Janeiro: Garamond, 2008.

Letras, 2009.

A terceira margem: em busca do ecodesenvolvimento. São Paulo: Companhia das

SANTAMARÍA, Ramiro Ávila. El derecho de la naturaleza: fundamentos. In: ACOSTA, Alberto, MARTÍNEZ, Esperanza (comp.). La naturaleza con derechos: de la filosofía a la política. Quito: Abya-Yala, 2011.

SANTILLI, Juliana. Agrobiodiversidade e direitos dos agricultores. São Paulo: Peirópolis, 2009.

SANTOS, Boaventura de Sousa. Introdução a uma ciência pós-moderna. 6. ed. Porto: Afrontamento, 2002.

Um discurso sobre as ciências. 7a. ed. São Paulo: Cortez, 2010a.

A gramática do tempo: para uma nova cultura política. 3. ed. São Paulo: Cortez, 
SCHADEN, EGON. Aspectos fundamentais da cultura Guarani. São Paulo: Edusp, 1974.

SCHAMA, Simon. Paisagem e memória. São Paulo: Companhia das Letras, 1996.

SCHNEIDER, Sergio. Reflexões sobre diversidade e diversificação agricultura, formas familiares e desenvolvimento rural. Ruris, v. 4, n.1, mar, 2010.

SCHUMACHER, E. F. O negócio é ser pequeno: um estudo de economia que leva em conta as pessoas. 3. ed. Rio de Janeiro: Zahar, 1981.

SEN, Amartya. Desenvolvimento como liberdade. São Paulo: Companhia das Letras, 2000.

SHIVA, Vandana. Monoculturas da mente: perspectivas da biodiversidade e da biotecnologia. São Paulo: Gaia, 2003.

SILVA, Joana A. Fernandes. Os Kaiová e a Ideologia dos Projetos Econômicos. 1982. Dissertação (Mestrado) - Universidade de Campinas/Unicamp, Campinas/SP.

SMITH, Linda Tuhiwai. Decolonizing methodologies: research and indigenous peoples. London, New York: Zed Books Ltd, 1999.

SOUZA FILHO, Carlos Frederico Marés de. 0 renascer dos povos indígenas para o Direito. Curitiba: Juruá, 2006.

(coord.). Estatuto dos Povos Indígenas: uma análise em face das determinações constitucionais e internacionais. Série Pensando o Direito, n. 19. Brasília: Secretaria de Assuntos Legislativos (SAL) do Ministério da Justiça, 2009.

SPELLER, Gerda M. A importância da vinculação aos lugares. In: SOCZKA, Luis (org.). Contextos Humanos e Psicologia Ambiental. Lisboa: Calouste Gulbenkian, 2005.

STAVENHAGEN, Rodolfo. Etnodesenvolvimento: uma dimensão ignorada no pensamento desenvolvimentista. Anuário Antropológico, Rio de Janeiro, v. 84, p. 13-56, 1985.

STEIL, Carlos Alberto, CARVALHO, Isabel Cristina de Moura. Introdução. In: STEIL, Carlos Alberto, CARVALHO, Isabel Cristina de Moura (orgs.). Cultura, percepção e ambiente: diálogos com Tim Ingold. São Paulo: Terceiro Nome, 2012.

STÖHR, Andreas. Ética e ecologia: um levantamento sobre os fundamentos normativos da ética ambiental. In: NOBRE, Marcos, AMAZONAS, Maurício de Carvalho. Desenvolvimento sustentável: a institucionalização de um conceito. Brasília: Ibama, 2002.

SUSNIK, Branislava. Los aborígenes del Paraguay. Asunción: Museo Etnografico "Andres Barbero", 1979.

TEÓFILO DA SILVA, Cristhian. Campo minado: considerações sobre o poder e a antropologia na identificação e delimitação de terras indígenas. In: LIMA, Antonio Carlos de Souza, BARRETO FILHO, Henyo Trindade (orgs). Antropologia e identificação: os antropólogos e a definição de terras indígenas no Brasil, 1977-2002. Rio de Janeiro: Contra Capa, LACED, CNPq, FAPERJ, IIEB, 2005.

TEÓFILO DA SILVA, Cristhian, CASTILHO, Ela Wiecko V. Em defesa dos direitos fundamentais dos povos indígenas e manifesto de repúdio contra 0 retrocesso 
constitucional e os ataques à democracia e ao pluralismo. 2013. Disponível em: <http://laepiceppacunb.blogspot.com.br//>. Acesso em: 10 out 2013.

THOMAZ DE ALMEIDA, Rubem Ferreira. Do desenvolvimento comunitário à mobilização política: o Projeto Kaiowá Ñandeva como experiência antropológica. Rio de Janeiro: Contra Capa, 2001.

Relatório circunstanciado de identificação e delimitação da Terra Indígena Jatayvary. Brasília: FUNAI, 2005.

THOREAU, Henry David. Walden ou a vida nos bosques. Porto Alegre: L\&PM, 2010.

TODOROV, Tzvetan. A conquista da América: a questão do outro. 4. ed. São Paulo: Martins Fontes, 2010.

TOLEDO, Víctor M. Ecologia, espiritualidade y conocimiento: de la sociedade del riesgo a la sociedade sustentable. México, DF: PNUMA, 2003.

TUAN, Yi-Fu. Topofilia: um estudo da percepção, atitudes e valores do meio ambiente. Londrina: Eduel, 2012.

Espaço e Lugar: a perspectiva da experiência. Londrina: Eduel, 2013.

UCDB. Atlas socioambiental terra indígena Te'ýikue. In: SMANIOTTO, Celso Rubens, RAMIRES, Lídio Cavanha, SKOWRONSKI, Leandro (Orgs). Campo Grande: UCDB, 2009.

ULLOA, Astrid. La construcción del "nativo ecológico". Bogotá: Instituto Colombiano de Antropologia e História, 2004.

Concepciones de la naturaleza en la antropología actual. In: MARTíNEZ, Leonardo Montenegro (ed.). Cultura y Naturaleza. Bogotá: Jardín Botánico de Bogotá, José Celestino Mutis, 2011.

UNKEL, Curt Nimuendaju. As lendas da criação e destruição do mundo: como fundamento da religião dos Apapocúva-Guarani. São Paulo: Hucitec, Edusp, 1987.

URQUIZA, Antonio Hilario Aguilera, NASCIMENTO, Adir Casaro. O desafio da interculturalidade na formação de professores indígenas. Espaço Ameríndio, Porto Alegre, v. 4, n. 1, p. 44-60, jan./jun. 2010.

VELA, Enrique. El maíz: catálogo visual - historia, simbolismo, botánica y gastronomía. Arqueología Mexicana, México/DF, n. 38, mar. 2011.

VIETTA, Kátia. Pastor dá conselho bom: missões evangélicas e igrejas neopentecostais entre os Kaiowa e os Guarani em Mato Grosso do Sul. Tellus, Campo Grande/MS, v. 3, n. 4 , p. $109-135, a b r / 2003$.

Histórias territoriais: a privatização das terras kaiowá como estratégia para a guarnição da fronteira brasileira e outras histórias. Espaço Ameríndio, Porto Alegre, v. 7, n. 2, p. 26-63, jul./dez. 2013.

VIOLA, Francesco. De la naturaleza a los derechos: los lugares de la ética contemporánea. Granada: Comares, 1997. 
VIVEIRO DE CASTRO, Eduardo. A inconstância da alma selvagem e outros ensaios de antropologia. São Paulo: Cosac Naify, 2011.

WHITT, Laurie Anne, ROBERTS, Mere, NORMAN, Waerete, GRIEVES, Vicki. Perspectivas indígenas. In: JAMIESON, Dale (coord). Manual de Filosofia do Ambiente. Lisboa: Instituto Piaget, 2003.

WILSON, Edward O. A criação: como salvar a vida na terra. São Paulo: Companhia das Letras, 2008.

Diversidade da vida. São Paulo: Companhia das Letras, 2012.

WORSTER, Donald. Para fazer história ambiental. Estudos Históricos, Rio de Janeiro, v. 4, n. 8, p. 198-215, 1991.

YIN. Robert K. Estudo de caso: planejamento e métodos. 4. ed. Porto Alegre: Bookman, 2010.

ZAFFARONI, Eugenio Raúl. La Pachamama y el humano. In: ACOSTA, Alberto, MARTÍNEZ, Esperanza (comp.). La naturaleza con derechos: de la filosofía a la política. Quito: Abya-Yala, 2011. 
ANEXOS

\section{ANEXO A - A CARTA DA TERRA}

\section{PREÂMBULO}

Estamos diante de um momento crítico na história da Terra, numa época em que a humanidade deve escolher o seu futuro. À medida que o mundo torna-se cada vez mais interdependente e frágil, o futuro enfrenta, ao mesmo tempo, grandes perigos e grandes promessas. Para seguir adiante, devemos reconhecer que, no meio da uma magnífica diversidade de culturas e formas de vida, somos uma família humana e uma comunidade terrestre com um destino comum. Devemos somar forças para gerar uma sociedade sustentável global baseada no respeito pela natureza, nos direitos humanos universais, na justiça econômica e numa cultura da paz. Para chegar a este propósito, é imperativo que nós, os povos da Terra, declaremos nossa responsabilidade uns para com os outros, com a grande comunidade da vida, e com as futuras gerações.

\section{TERRA, NOSSO LAR}

A humanidade é parte de um vasto universo em evolução. A Terra, nosso lar, está viva com uma comunidade de vida única. As forças da natureza fazem da existência uma aventura exigente e incerta, mas a Terra providenciou as condições essenciais para a evolução da vida. A capacidade de recuperação da comunidade da vida e o bem-estar da humanidade dependem da preservação de uma biosfera saudável com todos seus sistemas ecológicos, uma rica variedade de plantas e animais, solos férteis, águas puras e ar limpo. 0 meio ambiente global com seus recursos finitos é uma preocupação comum de todas as pessoas. A proteção da vitalidade, diversidade e beleza da Terra é um dever sagrado.

\section{A SITUAÇÃO GLOBAL}

Os padrões dominantes de produção e consumo estão causando devastação ambiental, redução dos recursos e uma massiva extinção de espécies. Comunidades estão sendo arruinadas. Os benefícios do desenvolvimento não estão sendo divididos equitativamente e o fosso entre ricos e pobres está aumentando. A injustiça, a pobreza, a ignorância e os conflitos violentos têm aumentado e são causa de grande sofrimento. $O$ crescimento sem precedentes da população humana tem sobrecarregado os sistemas ecológico e social. As bases da segurança global estão ameaçadas. Essas tendências são perigosas, mas não inevitáveis. 


\section{DESAFIOS PARA O FUTURO}

A escolha é nossa: formar uma aliança global para cuidar da Terra e uns dos outros, ou arriscar a nossa destruição e a da diversidade da vida. São necessárias mudanças fundamentais dos nossos valores, instituições e modos de vida. Devemos entender que, quando as necessidades básicas forem atingidas, o desenvolvimento humano será primariamente voltado a ser mais, não a ter mais. Temos o conhecimento e a tecnologia necessários para abastecer a todos e reduzir nossos impactos ao meio ambiente. $O$ surgimento de uma sociedade civil global está criando novas oportunidades para construir um mundo democrático e humano. Nossos desafios ambientais, econômicos, políticos, sociais e espirituais estão interligados, e juntos podemos forjar soluções includentes.

\section{RESPONSABILIDADE UNIVERSAL}

Para realizar estas aspirações, devemos decidir viver com um sentido de responsabilidade universal, identificando-nos com toda a comunidade terrestre bem como com nossa comunidade local. Somos, ao mesmo tempo, cidadãos de nações diferentes e de um mundo no qual a dimensão local e global estão ligadas. Cada um compartilha da responsabilidade pelo presente e pelo futuro, pelo bem-estar da família humana e de todo o mundo dos seres vivos. O espírito de solidariedade humana e de parentesco com toda a vida é fortalecido quando vivemos com reverência o mistério da existência, com gratidão pelo dom da vida, e com humildade considerando em relação ao lugar que ocupa o ser humano na natureza. Necessitamos com urgência de uma visão compartilhada de valores básicos para proporcionar um fundamento ético à comunidade mundial emergente. Portanto, juntos na esperança, afirmamos os seguintes princípios, todos interdependentes, visando um modo de vida sustentável como critério comum, através dos quais a conduta de todos os indivíduos, organizações, empresas, governos, e instituições transnacionais será guiada e avaliada.

\section{PRINCÍPIOS}

\section{RESPEITAR E CUIDAR DA COMUNIDADE DA VIDA}

1. Respeitar a Terra e a vida em toda sua diversidade.

a. Reconhecer que todos os seres são interligados e cada forma de vida tem valor, independentemente de sua utilidade para os seres humanos.

b. Afirmar a fé na dignidade inerente de todos os seres humanos e no potencial intelectual, artístico, ético e espiritual da humanidade.

2. Cuidar da comunidade da vida com compreensão, compaixão e amor. 
a. Aceitar que, com o direito de possuir, administrar e usar os recursos naturais vem o dever de impedir o dano causado ao meio ambiente e de proteger os direitos das pessoas.

b. Assumir que o aumento da liberdade, dos conhecimentos e do poder implica responsabilidade na promoção do bem comum.

3. Construir sociedades democráticas que sejam justas, participativas, sustentáveis e pacíficas.

a. Assegurar que as comunidades em todos níveis garantam os direitos humanos e as liberdades fundamentais e proporcionem a cada um a oportunidade de realizar seu pleno potencial.

b. Promover a justiça econômica e social, propiciando a todos a consecução de uma subsistência significativa e segura, que seja ecologicamente responsável.

4. Garantir as dádivas e a beleza da Terra para as atuais e as futuras gerações.

a. Reconhecer que a liberdade de ação de cada geração é condicionada pelas necessidades das gerações futuras.

b. Transmitir às futuras gerações valores, tradições e instituições que apoiem, em longo prazo, a prosperidade das comunidades humanas e ecológicas da Terra.

Para poder cumprir estes quatro amplos compromissos, é necessário:

II. INTEGRIDADE ECOLÓGICA

5. Proteger e restaurar a integridade dos sistemas ecológicos da Terra, com especial preocupação pela diversidade biológica e pelos processos naturais que sustentam a vida.

a. Adotar planos e regulamentações de desenvolvimento sustentável em todos os níveis que façam com que a conservação ambiental e a reabilitação sejam parte integral de todas as iniciativas de desenvolvimento.

b. Estabelecer e proteger as reservas com uma natureza viável e da biosfera, incluindo terras selvagens e áreas marinhas, para proteger os sistemas de sustento à vida da Terra, manter a biodiversidade e preservar nossa herança natural.

c. Promover a recuperação de espécies e ecossistemas ameaçadas.

d. Controlar e erradicar organismos não-nativos ou modificados geneticamente que causem dano às espécies nativas, ao meio ambiente, e prevenir a introdução desses organismos daninhos.

e. Manejar o uso de recursos renováveis como água, solo, produtos florestais e vida marinha de forma que não excedam as taxas de regeneração e que protejam a sanidade dos ecossistemas.

f. Manejar a extração e o uso de recursos não-renováveis, como minerais e combustíveis fósseis de forma que diminuam a exaustão e não causem dano ambiental grave. 
6. Prevenir o dano ao ambiente como o melhor método de proteção ambiental e, quando o conhecimento for limitado, assumir uma postura de precaução.

a. Orientar ações para evitar a possibilidade de sérios ou irreversíveis danos ambientais mesmo quando a informação científica for incompleta ou não conclusiva.

b. Impor o ônus da prova àqueles que afirmarem que a atividade proposta não causará dano significativo e fazer com que os grupos sejam responsabilizados pelo dano ambiental.

c. Garantir que a decisão a ser tomada se oriente pelas conseqüências humanas globais, cumulativas, de longo prazo, indiretas e de longo alcance.

d. Impedir a poluição de qualquer parte do meio ambiente e não permitir o aumento de substâncias radioativas, tóxicas ou outras substâncias perigosas.

e. Evitar que atividades militares causem dano ao meio ambiente.

7. Adotar padrões de produção, consumo e reprodução que protejam as capacidades regenerativas da Terra, os direitos humanos e o bem-estar comunitário.

a. Reduzir, reutilizar e reciclar materiais usados nos sistemas de produção e consumo e garantir que os resíduos possam ser assimilados pelos sistemas ecológicos.

b. Atuar com restrição e eficiência no uso de energia e recorrer cada vez mais aos recursos energéticos renováveis, como a energia solar e do vento.

c. Promover o desenvolvimento, a adoção e a transferência equitativa de tecnologias ambientais saudáveis.

d. Incluir totalmente os custos ambientais e sociais de bens e serviços no preço de venda e habilitar os consumidores a identificar produtos que satisfaçam as mais altas normas sociais e ambientais.

e. Garantir acesso universal à assistência de saúde que fomente a saúde reprodutiva e a reprodução responsável.

f. Adotar estilos de vida que acentuem a qualidade de vida e subsistência material num mundo finito.

8. Avançar o estudo da sustentabilidade ecológica e promover a troca aberta e a ampla aplicação do conhecimento adquirido.

a. Apoiar a cooperação científica e técnica internacional relacionada a sustentabilidade, com especial atenção às necessidades das nações em desenvolvimento.

b. Reconhecer e preservar os conhecimentos tradicionais e a sabedoria espiritual em todas as culturas que contribuam para a proteção ambiental e o bem-estar humano.

c. Garantir que informações de vital importância para a saúde humana e para a proteção ambiental, incluindo informação genética, estejam disponíveis ao domínio público. 


\section{JUSTIÇA SOCIAL E ECONÔMICA}

9. Erradicar a pobreza como um imperativo ético, social e ambiental.

a. Garantir o direito à água potável, ao ar puro, à segurança alimentar, aos solos nãocontaminados, ao abrigo e saneamento seguro, distribuindo os recursos nacionais e internacionais requeridos.

b. Prover cada ser humano de educação e recursos para assegurar uma subsistência sustentável, e proporcionar seguro social e segurança coletiva a todos aqueles que não são capazes de manter-se por conta própria.

c. Reconhecer os ignorados, proteger os vulneráveis, servir àqueles que sofrem, e permitir-lhes desenvolver suas capacidades e alcançar suas aspirações.

10. Garantir que as atividades e instituições econômicas em todos os níveis promovam o desenvolvimento humano de forma equitativa e sustentável.

a. Promover a distribuição equitativa da riqueza dentro das e entre as nações.

b. Incrementar os recursos intelectuais, financeiros, técnicos e sociais das nações em desenvolvimento e isentá-las de dívidas internacionais onerosas.

c. Garantir que todas as transações comerciais apoiem o uso de recursos sustentáveis, a proteção ambiental e normas trabalhistas progressistas.

d. Exigir que corporações multinacionais e organizações financeiras internacionais atuem com transparência em benefício do bem comum e responsabilizá-las pelas consequências de suas atividades.

11. Afirmar a igualdade e a equidade de gênero como pré-requisitos para o desenvolvimento sustentável e assegurar o acesso universal à educação, assistência de saúde e às oportunidades econômicas.

a. Assegurar os direitos humanos das mulheres e das meninas e acabar com toda violência contra elas.

b. Promover a participação ativa das mulheres em todos os aspectos da vida econômica, política, civil, social e cultural como parceiras plenas e paritárias, tomadoras de decisão, líderes e beneficiárias.

c. Fortalecer as famílias e garantir a segurança e a educação amorosa de todos os membros da família.

12. Defender, sem discriminação, os direitos de todas as pessoas a um ambiente natural e social, capaz de assegurar a dignidade humana, a saúde corporal e o bem-estar espiritual, concedendo especial atenção aos direitos dos povos indígenas e minorias.

a. Eliminar a discriminação em todas suas formas, como as baseadas em raça, cor, gênero, orientação sexual, religião, idioma e origem nacional, étnica ou social.

b. Afirmar o direito dos povos indígenas à sua espiritualidade, conhecimentos, terras e recursos, assim como às suas práticas relacionadas a formas sustentáveis de vida. 
c. Honrar e apoiar os jovens das nossas comunidades, habilitando-os a cumprir seu papel essencial na criação de sociedades sustentáveis.

d. Proteger e restaurar lugares notáveis pelo significado cultural e espiritual.

\section{DEMOCRACIA, NÃO VIOLÊNCIA E PAZ}

13. Fortalecer as instituições democráticas em todos os níveis e proporcionar-Ihes transparência e prestação de contas no exercício do governo, participação inclusiva na tomada de decisões, e acesso à justiça.

a. Defender o direito de todas as pessoas no sentido de receber informação clara e oportuna sobre assuntos ambientais e todos os planos de desenvolvimento e atividades que poderiam afetá-las ou nos quais tenham interesse.

b. Apoiar sociedades civis locais, regionais e globais e promover a participação significativa de todos os indivíduos e organizações na tomada de decisões.

c. Proteger os direitos à liberdade de opinião, de expressão, de assembleia pacífica, de associação e de oposição.

d. Instituir o acesso efetivo e eficiente a procedimentos administrativos e judiciais independentes, incluindo retificação e compensação por danos ambientais e pela ameaça de tais danos.

e. Eliminar a corrupção em todas as instituições públicas e privadas.

f. Fortalecer as comunidades locais, habilitando-as a cuidar dos seus próprios ambientes, e atribuir responsabilidades ambientais aos níveis governamentais onde possam ser cumpridas mais efetivamente.

14. Integrar, na educação formal e na aprendizagem ao longo da vida, os conhecimentos, valores e habilidades necessárias para um modo de vida sustentável.

a. Oferecer a todos, especialmente a crianças e jovens, oportunidades educativas que Ihes permitam contribuir ativamente para o desenvolvimento sustentável.

b. Promover a contribuição das artes e humanidades, assim como das ciências, na educação para sustentabilidade.

c. Intensificar o papel dos meios de comunicação de massa no sentido de aumentar a sensibilização para os desafios ecológicos e sociais.

d. Reconhecer a importância da educação moral e espiritual para uma subsistência sustentável.

15. Tratar todos os seres vivos com respeito e consideração.

a. Impedir crueldades aos animais mantidos em sociedades humanas e protegê-los de sofrimentos.

b. Proteger animais selvagens de métodos de caça, armadilhas e pesca que causem sofrimento extremo, prolongado ou evitável. 
c. Evitar ou eliminar ao máximo possível a captura ou destruição de espécies não visadas.

16. Promover uma cultura de tolerância, não violência e paz.

a. Estimular e apoiar o entendimento mútuo, a solidariedade e a cooperação entre todas as pessoas, dentro das e entre as nações.

b. Implementar estratégias amplas para prevenir conflitos violentos e usar a colaboração na resolução de problemas para manejar e resolver conflitos ambientais e outras disputas.

c. Desmilitarizar os sistemas de segurança nacional até chegar ao nível de uma postura não provocativa da defesa e converter os recursos militares em propósitos pacíficos, incluindo restauração ecológica.

d. Eliminar armas nucleares, biológicas e tóxicas e outras armas de destruição em massa.

e. Assegurar que o uso do espaço orbital e cósmico mantenha a proteção ambiental e a paz.

f. Reconhecer que a paz é a plenitude criada por relações corretas consigo mesmo, com outras pessoas, outras culturas, outras vidas, com a Terra e com a totalidade maior da qual somos parte.

\section{O CAMINHO ADIANTE}

Como nunca antes na história, o destino comum nos conclama a buscar um novo começo. Tal renovação é a promessa dos princípios da Carta da Terra. Para cumprir esta promessa, temos que nos comprometer a adotar e promover os valores e objetivos da Carta.

Isto requer uma mudança na mente e no coração. Requer um novo sentido de interdependência global e de responsabilidade universal. Devemos desenvolver e aplicar com imaginação a visão de um modo de vida sustentável aos níveis local, nacional, regional e global. Nossa diversidade cultural é uma herança preciosa, e diferentes culturas encontrarão suas próprias e distintas formas de realizar esta visão. Devemos aprofundar expandir o diálogo global gerado pela Carta da Terra, porque temos muito que aprender a partir da busca iminente e conjunta por verdade e sabedoria.

A vida muitas vezes envolve tensões entre valores importantes. Isto pode significar escolhas difíceis. Porém, necessitamos encontrar caminhos para harmonizar a diversidade com a unidade, o exercício da liberdade com o bem comum, objetivos de curto prazo com metas de longo prazo. Todo indivíduo, família, organização e comunidade têm um papel vital a desempenhar. As artes, as ciências, as religiões, as instituições educativas, os meios de comunicação, as empresas, as organizações não-governamentais e os governos são todos 
chamados a oferecer uma liderança criativa. A parceria entre governo, sociedade civil e empresas é essencial para uma governabilidade efetiva.

Para construir uma comunidade global sustentável, as nações do mundo devem renovar seu compromisso com as Nações Unidas, cumprir com suas obrigações respeitando os acordos internacionais existentes e apoiar a implementação dos princípios da Carta da Terra com um instrumento internacional legalmente unificador quanto ao ambiente e ao desenvolvimento.

Que o nosso tempo seja lembrado pelo despertar de uma nova reverência face à vida, pelo compromisso firme de alcançar a sustentabilidade, a intensificação da luta pela justiça e pela paz, e a alegre celebração da vida. 
Em quase todos os relatos o "Irmão Maior" e o "Irmão Menor", representados pelo Sol e pela Lua, respectivamente, são referidos como gêmeos e como dupla. Eles dão continuidade à dualidade inaugurada no ciclo anterior. Os principais momentos do mito mostram que a dualidade se manifesta através de características que se correlacionam seguindo o esquema ativo-passivo.

"Nossa Mãe" ficara grávida dos gêmeos quando "Nosso Pai" a abandonou. Disposta a reencontrar seu marido, ela se paramentou e saiu à sua procura, guiada pelos filhos, que ainda não tinham nascido. No caminho, a mãe briga com um deles - o "Irmão Maior" -, ao ser picada por um inseto quando tentava arrancar-lhe uma flor. Aparentemente, ele não se ofendeu com a atitude da mãe. Nisso repete a atitude tipicamente guarani, inaugurada pelo seu pai: não discute, mas não esquece a ofensa. Mais tarde, ao chegarem a uma encruzilhada, o filho decidiu se vingar. Viu sua mãe pegar o trecho que conduzia à casa dos jaguares demoníacos e não a advertiu. Os jaguares devoraram a "Nossa Mãe" e os gêmeos nasceram órfãos.

Os irmãos viveram na casa dos jaguares até que o papagaio lhes disse que eles moravam com os assassinos de "Nossa Mãe". Depois dessa revelação, eles saíram à procura dos restos da sua finada mãe. Após tê-los encontrado, a primeira grande tarefa de Kuarahy foi tentar ressuscitar sua progenitora, modelando sobre seus ossos um novo corpo feito de terra. Ele não conseguiu levar a obra a termo por uma imprudência de seu irmão menor. Ocorre a segunda morte de "Nossa Mãe" e com isso os irmãos ficam, definitivamente, órfãos. Então decidiram se vingar dos jaguares e se puseram a caminho para tal.

Caminhando, eles humanizaram o mundo, deixando-o habitável, pronto para ser morada do ser humano. Deram nome às frutas silvestres e a alguns animais; fizeram armadilhas; roubaram o fogo dos urubus; descobriram outros seres humanos, alguns inimigos e seus futuros cunhados. Para humanizar o mundo, porém, tiveram que derrotar o principal inimigo do ser humano, o jaguar. Esse é o único animal que pode comer o ser humano e rivalizar com ele. Sua representação é o Aña, uma espécie de demônio. Em uma de suas travessuras, o "Irmão Menor" causou um problema com Aña, que o matou. O "Irmão Maior" intercedeu, pedindo a Aña que the entregasse os ossos de seu irmão, com os quais ele o ressuscitou. Já cansado das trapalhadas do seu irmão, o "Irmão Maior" decidiu separar-se dele, aparecendo, hoje, somente quando seu irmão se esconde. Assim se originaram a noite (ciclo lunar) e o dia (ciclo solar). (...)

Mas os dois irmãos voltaram a se encontrar e a se ocupar com o motivo que desencadeou a migração guarani: reencontrar-se com "Nosso Pai". Dispostos a enfrentar 
todas as dificuldades para alcançar o objetivo original, os irmãos são desafiados pelo seu pai a construir o caminho que os levasse até ele. O "Irmão Maior" inventou muitas flechas e as disparou no firmamento para preparar o sendeiro que os levasse até "Nosso Pai". O resultado foi uma verdadeira "coluna de flechas", pela qual os dois irmãos ascenderam, para ocupar cada um seu respectivo lugar no firmamento. Finalmente se encontraram com o pai. O "Irmão Maior" Ihe fez muitas perguntas e Ihe pediu sua indumentária e seus atributos xamânicos. Nosso Pai, atendendo ao seu pedido, o instituiu grande xamã. Depois disso, o protopai abandonou novamente a cena. Enquanto isso, o "Irmão Menor" tinha reencontrado sua mãe e mamado nos seus seios.

Quando os dois irmãos finalmente chegaram à casa de "Nossa Mãe", foram recebidos pela arara, que lhes ofereceu frutas, pão, mel silvestre e bebida feita de milho. "Nossa Mãe" os cumprimentou com a saudação lacrimosa típica dos Tupi-Guarani e lhes disse: "Na terra, a morte é o fim de vocês. Não voltem para lá, fiquem agora aqui!" E iniciou-se a festa! (Melià \& Grünberg, 1976, p. 230-232; Perasso, 1986, p. 42-45; Nimuendaju, 1987, p. 135-141; Bartolomé, 1991, p. 43-59). Até aqui, vimos o mito fundador do ciclo dos gêmeos. 


\section{ANEXO C - EXCERTOS DA CONSTITUIÇÃO DO EQUADOR SOBRE OS DIREITOS DA NATUREZA}

Capítulo séptimo: Derechos de la Naturaleza

Art. 71. La naturaleza o Pachamama, donde se reproduce y realiza la vida, tiene derecho a que se respete integralmente su existencia y el mantenimiento y regeneración de sus ciclos vitales, estructura, funciones y procesos evolutivos.

Toda persona, comunidad, pueblo o nacionalidad podrá exigir a la autoridad pública el cumplimiento de los Derechoos de la Naturaleza. Para aplicar e interpretar estos derechos se observaran los principios establecidos en la Constitución, en lo que proceda.

El Estado incentivará a las personas naturales y jurídicas, y a los colectivos, para que protejan la naturaleza, y promoverá el respeto a todos los elementos que forman un ecosistema.

Art. 72. La Naturaleza tiene derecho a la restauración. Esta restauración será independiente de la obligación que tienen el Estado y las personas naturales o jurídicas de indemnizar a los individuos y colectivos que dependan de los sistemas naturales afectados.

En los casos de impacto ambiental grave o permanente, incluidos los ocasionados por la explotación de los recursos naturales no renovables, el Estado establecerá los mecanismos más eficaces para alcanzar la restauración, y adoptará las medidas adecuadas para eliminar o mitigar las consecuencias ambientales nocivas.

Art. 73. El Estado aplicará medidas de precaución y restricción para las actividades que puedan conducir a la extinción de espécies, la destrucción de ecosistemas o la alteración permanente de los ciclos naturales.

Se prohíbe la introducción de organismos y material orgánico e inorgánico que puedan alterar de manera definitiva el patrimonio genético nacional.

Art. 74. Las personas, comunidades, pueblos y nacionalidades tendrán derecho a beneficiarse del ambiente y de las riquezas naturales que les permitan el Buen Vivir.

Los servicios ambientales no serán susceptibles de apropiación; su producción, prestación, uso y aprovechamiento serán regulados por el Estado. 


\section{GLOSSÁRIO}

Ára Verá - Tempo iluminado.

Arandu - Conhecimento.

Apyká - Banquinho.

Aty Guasu - Grande Assembleia.

Avá- Homem guarani.

Avareko - De natureza humana.

Avati-Espécie de milho.

Changa - Trabalho remunerado fora das terras indígenas.

Che Rogami - Minha casinha.

Che ypyky kuera - Fogo familiar.

Guachire - Festa profana.

Jara - Donos dos seres não-humanos.

Jakaira - Dono das plantas agrícolas.

Jasy - Lua, irmão menor no mito dos gêmeos.

Jeroky - Dança.

Híu - Cabeça de parentela.

Ka'aguy - Floresta, mato.

Ka'aguy jara - Dono da floresta.

Kaja'a - Dono dos seres da água.

Karaí- Homem branco.

Kotyhu - Festa, comemoração, cantos.

Kuarahy - Sol. Irmão maior no mito dos gêmeos.

Mbaraka - Chocoalho.

Mborayu - Reciprocidade.

Mburuvicha - Líder.

Mimbý - Espécie de flauta-assobio feita de madeira.

Mymbá - Animais silvestres.

Ñandejára - Princípio supremo, Tupã, Deus.

Nanderú - Nosso pai. Rezador ou chefe religioso.

Ñanderú Guasu - Nosso grande pai, alto Deus criador.

Ñandecý/Ñandesý - Nossa mãe, rezadora.

Nande Reko - Nosso modo de ser.

$\tilde{N} e^{\prime e ̈-P a l a v r a, ~ a l m a . ~}$

Nembo'e - Reza. 
Ogapysy - Casa de reza.

Ogwatá/Oguatá - Caminhar, andar.

Omboka'aguyjevy - Reflorestamento espontâneo.

Oyguatsú - Casa de festas religiosa.

Oygusu - Habitação grande.

Pa'irei-Mundo subterrâneo.

Porahéi- Canto tradicional.

Quatiá - Conversa.

Rymbá - Animais domésticos.

Sarambi - Estar esparramado, espalhado, Dispersão de Tekohas.

So'o jára - Dono dos animais.

Tape po'i- Trilhas.

Teko - Modo de ser.

Tekoaruvicha - Líder religioso próprio.

Teko Arandu - Viver em sabedoria.

Teko Jára - Dono do ser.

Teko Porã - Bom modo de ser.

Tekoha - Lugar onde se realiza o modo de ser.

Tekoha Guasu - Conjunto de tekoha.

Teko Katu - Modo correto de se viver, boa vida, livre, vida justa e perfeita.

Tekove Porã - De natureza boa, bom viver.

Tembetá - Resina colocada abaixo do lábio.

Téyi- Família, aglutinação de parentes.

Mburuvixa, Yvyra'ija - Líder político.

Yvaga - Céu.

$Y v u$ - Manancial, fonte.

Yvy-Terra.

Yvy Jára - Dono da terra.

Yvy Poty - Flor da Terra.

Yvyra - Árvore.

Yvy Marane '́̃ - Solo, terra intacta. 